\title{
CONSTRUÇÃO DE UM PROJETO DE SAÚDE OCULAR PARA CRIANÇAS \\ - ANÁlISE DO PROCESSO DE PARTICIPAÇÃO, MORUNGABA, SP - 2000
}

\author{
ANA MARIA GIROTTI SPERANDIO
}

Tese apresentada ao Departamento de Saúde MaternoInfantil da Faculdade de Saúde Pública, Universidade de São Paulo para obtenção do Grau de Doutor em Saúde Pública.

Área de Concentração: Saúde Materno-Infantil

ORIENTADORA:

Prof ${ }^{a}$ Dr ${ }^{a}$ Keiko Ogura Buralli

VOLUME I

São Paulo 2001

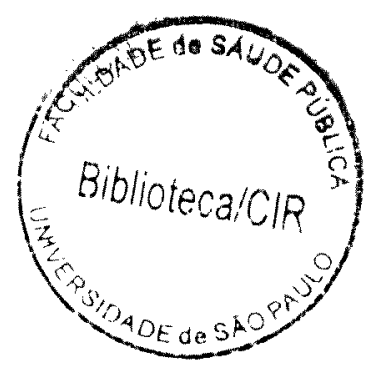


Autorizo, exclusivamente para fins acadêmicos e científicos, a reprodução total ou parcial desta tese, por processos fotocopiadores.

Assinatura:

Data:

$$
41793 / 2002 \text { dot }
$$




\section{AGRADECIMENTOS}

Ao CNPq, pelo apoio financeiro para o desenvolvimento desta pesquisa.

À Prof ${ }^{a}{ }^{D} r^{a}$ Keiko Ogura Buralli, pelo respeito, carinho, dedicação e alegria com que conduziu o meu processo de aprendizado para elaboração desse Projeto.

À Profa ${ }^{a} r^{a}$ Fumika Peres, do Depto de Saúde Materno-Infantil da FSP/USP, pelo incentivo e valiosas sugestões durante o processo de construção desta tese.

À Prof a Associada Maria Cecília F. Pelicioni, do Depto. Prática de Saúde Pública da FSP/USP, pela leitura crítica da tese, que gerou observações pertinentes e sugestões de grande relevância.

Ao Prof. Dr. Carlos Roberto Soares Freire de Rivoredo, do Depto. de Pediatria Social da UNICAMP, pelo seu esforço, em fase de convalescença, em contribuir com seu profundo conhecimento para o refinamento deste estudo.

À Prof ${ }^{a}$ Dr ${ }^{a}$ Néia Schor, por sua atenção $e$ acolhimento nos momentos difíceis.

À Iara, Leandro, Soninha, Elba, Maria e demais funcionários do Departamento de Saúde Materno Infantil da FSP/USP, pela colaboração $e$ disposição em me auxiliarem.

Ao pessoal da Biblioteca da FSP/USP, em especial, Ângela e Marıa Lúcia, pela orientação e revisão bibliográfica.

À Angelina Frare Tobias, Prefeita de Morungaba até dezembro de 2000 , pela receptividade, motivação e respeito ao desenvolvimento do Projeto de Saúde Ocular, iniciado durante sua gestão. 
À atual Prefeita de Morungaba, Profa. Maria Cecília Pretti Rossi, que garantiu a continuidade do Projeto de Saúde Ocular, iniciado na gestão anterior, com grandes contribuições e dinamismu.

À companheira de trabalho e lutadora, Maria Tereza Coimbra. Diretorn de Educação e Cultura, da Prefeitura de Morungaba até dezembro de 2000 , pela perspicácia na identificação da abrangência do Trabalho, pela iniciativa de articulação, pelo respeito, carinho e dedicação dispensados

Aos diretores, coordenadores pedagógicos, professores, educadores de creche das escolas públicas e privadas, da cidade de Morungaba, que participaram ativamente do Projeto, construindo diferentes caminhos $e$ dando-lhe vida.

Ao Pessoal da Pastoral da Criança de Morungaba, coordenada pelo Sr. Armando, pela disposição em aprender para contribuir com o Projeto, conferindo-lhe maior abrangência.

Ao pessoal do Centro de Saúde Dr Romeu Bueno de Aguiar, de Morungaba, em especial à equipe de enfermagem, pela dedicada participaçăo no Projeto.

Ao Grupo de mães do bairro de São Benedito, da cidade de Morungaba, pela disposição em aprender e pela divulgação do Projeto

Aos funcionários da Prefeitura de Morungaba, que colaboraram e continuam colaborando, de modo direto ou indireto, para (re)construçáo do Projeto

À fabrica de armações Sorel e a óptica Nossa Senhora do Belém pelas doações dos óculos para as crianças que participaram do Projeto 
À minha querida mãe e à minha amorosa tia Neide, que durante todo o percurso de todo o trabalho, estiveram presentes para ajudarem no que fosse necessário.

À Alessandra Sabino, por sua dedicação aos meus filhos, na minha ausência, e por sua prontidão para ajudar-me com os materiais de apoio do Projeto.

E finalmente, às pessoas que no dia a dia da minha vida, ajudaram-me a enfrentar pequenas e grandes dificuldades, com amor e muita paciência: Juliana, Pedro e a você, meu eterno companheiro Henrique. 


\section{DEDICATÓRIA}

Dedico esta tese as crianças, as de Morungaba e aos meus filhos, por entender que, sem a perspectiva do futuro ao vivo, os nossos desejos e sonhos por mudanças acabam esmorecendo com o passar dos anos... Eles serão os atores sociais que irão compor a história do nosso País. 


\section{ÍNDICE}

RESUMO

SUMMARY

1 - APRESENTAÇÃO

- Aproximação do objeto de estudo ___ 2

2 - INTRODUCÃO__ 16

2.1 - Saúde Pública e Saúde Ocular___ 18

2.2 - Problemas oftalmológicos mais freqüentes em crianças ___ 22

2.3 - A concepção e construção da Promoção da Saúde no Mundo - principais referenciais históricos 30

2.4 - Saúde Ocular no contexto da promoção da saúde ___ 51

2.5 - Participação: principais concepções _ 54

3. OBJETIVO 76

4. PROCESSO METODOLÓGICO DA PESQUISA___ 77

4.1 - Abordagem sobre o método _ 77

4.2 - Delimitação do quadro de referência teórico___ 84

4.2.1 - Eixos norteadores do estudo _ 84

4.2.2. Estratégias de um Projeto de Promoção da Saúde Ocular e Prevenção

Precoce de Problemas Visuais___ 89

4.3 - Cenário do estudo ___ 98

4.4 - Sujeitos do estudo ___ 110

4.5- Etapas metodológicas ___ 111

4.5.1- Coletas de dados 112

4.5.2 - Organização e análise dos dados____ 113

5 - RESULTADOS_ 119

5.1 - Descrição do processo vivenciado ___ _ _ 119

5.2 - Resultados em construção _ـ 190

6 - CONSTOERAÇÕES FINAIS__ 252

7 - REFEREANCIAS __ 257

\section{Anexos}


Tabela 1 - Distribuição dos atores sociais treinados em saúde ocular em relação ao total existente, Município de Morungaba, 2000

Tabela 2 - Número de crianças que foram triadas, segundo as 193 categorias de atores sociais, Morungaba, 2000

Tabela 3 - Número e proporção de crianças de 0 a 7 anos triadas, 194 segundo os atores sociais que participaram do Projeto, Morungaba, 2000

Tabela 4 - Frequiência de crianças da Creche, da Educação Infantil e 195 Ensino Fundamental das escolas Municipais, Estaduais, Estaduais Rurais e Privadas, que foram triadas pelos professores e monitores de creche, até a quarta série do Ensino Fundamental das Escolas Estaduais, Morungaba, segundo faixa etária, 2000

Tabela 5 - Taxa de crianças triadas na Creche, na Educação Infantil e 196 no Ensino Fundamental (até a quarta série), em relação ao número de crianças matriculadas segundo o Censo Escolar 2000. Morungaba, 2000

Tabela 6 - Taxa de crianças de 0 a 7 anos de idade triadas, entre 198 matriculadas na creche, nas escolas de educação infantil e ensino fundamental, segundo tipo de unidade escolar, Morungaba, 2000

Tabela 7 - Proporção de crianças menores de 7 anos com problemas 199 visuais, triadas por professores e monitores da Creche, da Educação Infantil e Ensino Fundamental das escolas Municipais, Estaduais Urbanas, Estaduais Rurais e Privadas, segundo grupos etários. Morungaba, 2000

Tabela 8 - Número e proporção de crianças das Creches e Escolas, 200 segundo tipo de problema visual, por grupo etário, Morungaba, 2000 
Tabela 10 - Número e proporção de crianças triadas pela Pastoral da 203 Criança, segundo tipo de problema visual, confirmado pelo médico oftalmologista. Morungaba, 2000

Tabela 11 - Número e proporção de crianças com problemas visuais 204 confirmados por médico oftalmologista, após triagem dos professores, educadores de creche e pessoal da Pastoral a Criança, por grupos etários. Morungaba, 2000

Tabela 12 - Número e proporção de crianças com suspeita de problema 205 visual, que recorreram à consulta oftalmológica, segundo 0 tipo de serviço procurado, Morungaba, 2000

Tabela 13 - Número e porcentagem de acertos sobre os conhecimen- 207 tos adquiridos em saúde ocular, segundo o grupo de atores sociais, Morungaba, 2000 
Figura. 1 - Modelo de Planejamento de Intervenção Adaptado

Figura 2 - Mapa Cartográfico de Morungaba - SP, 2000

Figura 3 - "Slogan" do Projeto de Saúde Ocular, Morungaba - SP, 2000

Figura 4 - Capa do Manual Ver e Viver

Figura 5 - Personagens criados para o Projeto

Foto 1 - Município de Morungaba Estância Climática

Foto 2 - Vista panorâmica da Cidade de Morungaba - SP, 2000

Foto 3 - Faixa do Projeto Ver e Viver, afixada na fachada do Serviço de Assistência Social N. Sra. da Conceição

Foto 4 - Sessão de treinamento com Professores Jogo Olho Mágico

Foto 5 - Reunião dos professores e educadores de creche para definirem como seria o projeto de saúde ocular em sala de aula, Morungaba SP, 2000

Foto 6 - Atividade pedagógica sobre saúde ocular em uma escola Municipal de Morungaba - SP, 2000

Foto 7 - Atividade pedagógica sobre saúde ocular em uma escola Municipal de Morungaba - SP, 2000

Foto 8 - Crianças da EMEI São Benedito em grupos para discutir sobre a saúde ocular, Morungaba, 2000

Foto 9 - Avaliação da acuidade visual com o método de Snellen na Escola Estadual Rural, Morungaba, 2000

Foto 10 - Atividade pedagógica sobre saúde ocular com as crianças da Creche Municipal de Morungaba, 2000

Foto 11 - Exposição dos trabalhos pedagógicos realizados pelos alunos das escolas Estaduais, Municipais, Privadas e Creche Municipal de Morungaba, 2000 
Foto 12 - Trabalho pedagógico sobre saúde ocular com as crianças da Creche Municipal de Morungaba, 2000

Foto 13 - Treinamento prático na Escola Privada de Morungaba, 2000

Foto 14 - Aplicação do teste de angular "mãozinha", Morungaba, 2000

Foto 15 - Técnica de sensibilização utilizada nos treinamentos de ações básicas de saúde ocular, Morungaba, 2000

Foto 16 - Treinamento sobre ações básicas de saúde ocular para pessoal para saúde, Morungaba, 2000

Foto 17 - Teste de acuidade visual com o método de Snellen realizado no Centro de Saúde de Morungaba, 2000

Foto 18 - Treinamento teórico sobre Ações Básicas de Saúde Ocular de pessoal da Pastoral da Criança, Morungaba, 2000

Foto 19 - Treinamento prático sobre Ações Básicas de Saúde Ocular de pessoal da Pastoral da Criança, na zona rural de Morungaba, 2000

Foto 20 - Pasta com material de treinamento fornecida a todos os participantes, Morungaba, 2000

Foto 21 - Pessoal da Pastoral da Criança, realizando triagem visual, utilizando - método "Reação à Oclusão" em crianças da zona rural de Morungaba, 2000

Foto 22 - Teste de Snellen realizado pelo pessoal da Pastoral da Criança na zona rural, Morungaba, 2000

Foto 23 - Criança da zona rural, respondendo ao teste visual, aplicado por pessoal da Pastoral da Criança, Morungaba, 2000

Foto 24 - Treinamento teórico em Ações básicas de Saúde Ocular de mães de crianças menores de 7 anos de idade, da EME São Benedito, Morungaba, 2000

Foto 25 - Treinamento prático em Ações Básicas de Saúde Escolar com mães, Morungaba, 2000 


\section{RESUMO}

Sperandio $A M G$. Construção de um projeto de saúde ocular para crianças Análise do processo de participação vivenciado por atores sociais do Município de Morungaba, SP - 2000. [Tese de Doutorado - Faculdade de Saúde Pública da USP].

O presente estudo teve, como objeto, a construção de um projeto de promocão da saúde ocular e prevenção de problemas visuais voltado para crianças com idade abaixo de sete anos no município de Morungaba, SP, com a participação de atores sociais locais - educação, saúde, ONG e famílias - que interagem, de alguma forma com essa população infantil. Trata-se de um projeto de investigação-ação que visou, a análise do processo desenvolvido, com ênfase na participação dos atores sociais, utilizando um processo metodológico que foi sendo construído durante o desenvolvimento do próprio projeto. A análise compreendeu dois níveis: 1) em nível macro, a participação foi considerada na direção da promoção da saúde, tomando como componentes estratégicos de ação: a educação em saúde, o fortalecimento dos indivíduos, a intersetorialidade, a interinstitucionalidade, para a construção concreta de redes de comunicação $e$ de apoio por meio de parcerias. 2) no nível micro, a participação de cada ator social foi analisada quanto ao significado e à forma como as ações/atividades foram realizadas, segundo as categorias construidas. Os instrumentos de coleta de dados foram: questionários, entrevistas, diário de campo, fotografias. Resultados: Participaram do estudo 61 atores sociais da Educação, Saúde, Pastoral da Criança e mães: as atividades mais desenvolvidas e referidas por eles foram: planejamento do trabalho educativo com as crianças $e$ realização de testes visuais. Os atores sociais triaram 981 crianças, sendo 722 menores de 7 anos, destes 587 , de escolas municipais, estaduais e privadas: 73 $(12,4 \%)$ deles, apresentaram problemas visuais e 51 receberam óculos doados. Os marcos significativos de participação mais citados foram o aprendizado adquirido, a união dos participantes, o profissionalismo da coordenação e a dificuldade de aplicar os testes em crianças menores de 3 anos. Foram implementadas no Município: ações de educação em saúde desenvolvidas com os atores sociais e destes, com as crianças, população-alvo; ações inter-setoriais e inter-institucionais - Prefeitura, Educação, Saúde, ONG e parcerias com empresas locais. A liderança político-institucional local assumiu e desencadeou o projeto, comprometendo-se com sua continuidade: uma lei foi criada, institucionalizando ações de promoção da saúde ocular e prevenção de problemas visuais na rede pública de ensino; órgãos representativos da população apoiaram o Projeto: ocorreu a articulação do setor público com o privado e a integração inter e intra-setoriais; órgãos de comunicação apoiaram e efetuaram a cobertura das ações; o Projeto passou a apresentar condições para ser auto sustentável.

Descritores: Promoção da saúde. Saúde Ocular. Crianças. Intersetorialiaade. 


\section{SUMMARY}

Sperandio AMG. Construction of an eye health project for children Analysis of the participation process experienced by the social actors from Morungaba county, SP. - 2000. [Tese de Doutorado - Faculdade de Saúde Pública da USP].

This study purpose was the building of a Project of eye health promotion ard visual problem prevention to the children under 7 years in the county of Morungaba, SP, with the participation of local social actors - from education and health sectors, non governmental organizations and from families - which interact with this childish population. This was an investigation-action Project which aimed at analysing the developed process focusing on the social actors participation, utilizing a methodological process built during the development of the Project. The analysis was done in two levels: 1) in the macro one, the participation was considered in the direction of the health promotion, taking as strategic action components: the health education, the empowerment of the citizens, the relationship between the different sectors and institutions, to the building of comunication and support networks through partnerships. 2) in the the micro level, each social actor participation was analysed according to the meaning and the shape of how the actions/activities were accomplished, following the built categories. The survey tools were: questionaries, enterviews, field diary and photografies. Results: 61 social actors from Municipal Education Department, Health, Children's Pastoral and community mothers's group participated in the study; the more frequent activities referred by them were the planning of the educational work with the children and visual screening. They screened 981 children, 722 under 7 years old being 587 from the public and private schools: $73(12,4 \%)$, presented visual problems and 51 received donated glasses. The more cited meaningful participation issues were the acquired knowledge, the participants integration, the professionalism of the coordination and the difficulty of screening children under 3 years. It was implemented in the County: health education actions developed with the social actors that utilized such knowledge with the children, the targeted population; actions among different sectors and institutions (County Administration, Education, Health and Non Governmental organization). Partnerships were established with local companies. The political and institutional local leadership took the Project over and were commited to its continuity: a law was created institutuionalizing the eye health promotion and visual problem prevention in the public education; several sectors from population support the actions; public and private sectors ran the Project through integrated ations; inter and intra sectoriality were achieved; communication entities supported and covered the activites; the Project established conditions for self sustentation.

Descriptors: Health Promotion. Eye Health. Children. Sectorial Integration. 


\section{1 - APRESENTAÇÃO}

Com o propósito de analisar o processo de participação vivenciada por atores sociais na construção de um projeto de promoção da saúde ocular e prevenção precoce de problemas visuais para crianças de 0 a 7 anos de idade no Município de Morungaba, SP, foi necessário o envolvimento da autora deste estudo no processo de construção do Projeto, na condição de pesquisadora e, também, de ator social.

Quer dizer, para a concretização da intenção apresentada, foi preciso elaborar um Projeto, junto com os atores sociais locais, tendo, como objetivo, promover a saúde ocular e detectar precocemente problemas visuais mais frequentes em crianças de 0 a 7 anos, do município de Morungaba, SP.

O desenvolvimento do Projeto foi na perspectiva da promoção da saúde, buscando-se, coletivamente, a construção de parcerias entre os diferentes setores no Município, tendo como caminho norteador o processo educativo.

Os diferentes momentos contemplados nesse percurso foram: aproximação da pesquisadora do local e das pessoas para conhecimento da realidade; formação de parcerias; execução do Projeto, sistematização e divulgação dos resultados.

Foi somente a partir desse movimento e ampliação coletiva de novos caminhos em direção à consecução dos objetivos desse Projeto, que se 
tornou possível a análise da participação dos diferentes atores sociais, vivenciada no processo de construção do mesmo, objeto de estudo desta tese.

Complexo? Não apenas... mas, também, agregador, modificador e desafiante.

O que se defende nas entrelinhas desta pesquisa, é que é possível coletivizar ações de saúde, com a participação de diferentes atores sociais, mediante o desenvolvimento de um processo de (re)aprendizado de valores e objetivos comuns, da comunidade ao setor público, deste ao privado, deste para ONG, formando-se, assim, uma rede de comunicação e de trabalho solidário.

\section{Aproximação do objeto de estudo}

Conhecer a razão da escolha do tema desta tese requer estar relatando o processo que me levou a me aproximar do objeto de estudo. Esse percurso foi, e está sendo, um longo caminho, permeado de vitórias, perdas, surpresas, acertos, erros e, principalmente, renovado por conhecimentos de várias áreas disciplinares. Os momentos foram sendo construídos passo a passo, em um processo que demandou dedicação $e$ clareza de objetivos. Expressa uma história de aprendizado, de batalhas, em que diferentes atores sociais vêm contribuindo para o meu crescimento profissional.

Creio ser interessante remontar a história desde a minha formação na época da minha graduação em Ortóptica. 
Em face da pouca familiaridade existente com relação ao ortoptista e seu campo de atuação, julgo oportuno estar apresentando o profissional e sua competência, ainda que de forma sucinta.

O Ortoptista é um profissional de saúde, de nível superior, que cuida da reabilitação visual e estimulação das funções binoculares, atuando, portanto, na prevenção da cegueira (ALVARO 1957: KINKER 1984).

Segundo o American Journal Orthoptic e a American Orthoptics Council(1999):

"Ortoptica é uma profissão da saúde que tem como objetivo avaliar e tratar as desordens visuais, movimentos dos olhos $e$ o alinhamento dos olhos de crianças e adultos. Como consultor, um ortoptista deve visitar serviços e clínicas para ver pacientes ou participar como profissional conselheiro para atividades comunitárias que se preocupem com a visão. Ortoptista freqüentemente trabalha como diretor de programas de proteção visual, em nível local e estadual".

No Brasil, o primeiro curso de Ortóptica foi ministrado no Centro de Estudos de Oftalmologia da Escola Paulista de Medicina em 1947. Esta nomenclatura permaneceu até 1995, ou seja, durante 52 anos de existência, formando aproximadamente 500 profissionais (KINKER 1984).

De 1996 em diante, o Curso de Ortóptica passou a ser designado Tecnologia Oftálmica, contando com uma carga horária maior para a formação de seus profissionais.

O curso de Ortóptica é, também, ministrado pelo Instituto Brasileiro de Medicina e Reabilitação (IBMR), desde 1976. 
A atuação profissional vem se restringindo, ainda, ao consultório particular, vinculada ao oftalmologista e a hospitais de grande porte.

Tive o primeiro desejo de compreensão desse fato há 15 anos: como as crianças e adultos que não tinham acesso ao serviço privado e que necessitavam de assistência curativa de ortóptica estavam se "virando"? Quais as condições sensoriais - visuais, apresentadas por esses pacientes, tendo em vista que o sucesso para o tratamento de algumas patologias tem uma estreita relação com a idade em que o paciente iniciou 0 tratamento? Sabe-se que algumas patologias devem ser tratadas até 7 anos de idade.

Além desse fato, apesar de até então não ter tido contato com conhecimentos básicos de saúde pública, o que me causava uma certa inquietude era: - por quê os ortoptistas tratavam apenas do doente, ou pior, da doença? Acreditava que deveria existir alguma forma de trabalhar antes da instalação da doença.

Essas indagações foram me incomodando e me movimentando na direção de buscar respostas e caminhos para essas questões.

Foi assim que, em um determinado dia (no ano da minha formatura 1984), tive a oportunidade de ter acesso a informações sobre saúde pública e do setor público, ao participar de uma seleção pública, que me possibilitaria obter uma bolsa de estudos para realizar um estágio de aprimoramento em saúde pública junto a outros profissionais. O estágio era financiado pela Fundação do Desenvolvimento Administrativo FUNDAP, por um período de dois anos (após 1984, só houve mais uma seleção para ortoptista). Ao iniciar o estágio, no segundo semestre de 1984, tive acesso a informações básicas sobre programas e 
funcionamento de unidades de saúde na área de saúde pública, através de palestras, documentos e visita a um centro de saúde; em relação à área de saúde ocular no setor público, obtive também informações a partir de documentos oficiais, como o Plano de Oftalmologia Sanitária (POSE) e o Plano Nacional de Saúde Ocular (PNSO) que estava em discussão na época (1984). Tive acesso a objetivos e propostas metodológicas para implantar planos e projetos, diretrizes e recursos humanos disponiveis para a efetivação dos mesmos, assim como a definição das ações básicas de saúde ocular. Nessa época, tive a oportunidade de participar de algumas reuniões, na condição de ouvinte $e$, também, de treinamentos de profissionais, dentre eles, oftalmologistas vinculados ao setor público, que iriam executar as ações previstas no PNSO.

A partir da leitura desses documentos oficiais, apostilas de treinamento em saúde ocular e, principalmente, do contato com outros profissionais estagiários de diferentes áreas, a minha percepção da situação de saúde ocular no setor público começou a tomar forma. Decidi ter uma conversa com a minha orientadora de estágio, a oftalmologista Dra Elaine Ferreira, que me apoiou em todo o meu processo inicial de aprendizado, durante os 2 anos de estágio, resultando daí, a sugestão de esboçar um pequeno projeto, seguindo as diretrizes do PNSO e do POSE, a ser desenvolvido em uma comunidade da área de abrangência de um centro de saúde.

O desafio estava lançado: deveria articular conhecimentos específicos com os de uma outra área, cuja dimensão do saber era maior e mais complexa, em um momento em que o conhecimento sobre ela (saúde pública) ainda estava por vir a se formar. Tudo era descoberta e 
aprendizado, dentre outras coisas, teria que aprender a redigir $e$ apresentar um projeto. Coloquei no papel as minhas idéias, aquilo que achava sensato dentro de uma visão bastante fragmentada. Esse projeto tentava traçar, também, a atuação do ortoptista na unidade de saúde, volto a repetir, dentro de uma visão ainda limitada, apesar do enfoque multiprofissional, com ênfase na multiplicação de conhecimentos básicos com médicos, enfermeiros, auxiliares de enfermagem $e$ outros profissionais do centro de saúde e na educação, com professores.

O objetivo geral daquele projeto, em 1985, era detectar precocemente problemas visuais, através da transmissão de conhecimentos básicos de saúde ocular, priorizando crianças de 3 a 8 anos, usuárias da unidade de saúde e da comunidade. A questão da participação das pessoas ainda não era alvo da minha atenção, o que interessava na época era se o projeto conseguiria atingir um maior número de crianças $e$ se as pessoas que estavam envolvidas no processo de trabalho estavam realizando corretamente os testes visuais.

Precisava realizar um pré-teste do projeto, em alguma comunidade. Para tanto, surgiu a idéia de aplicá-lo, em 1985, em uma cidade chamada Cruzeiro, cerca de $200 \mathrm{~km}$ da capital de São Paulo, lugar em que havia passado as férias durante toda a minha infância. A proposta do projeto era multiplicar conhecimentos básicos da área e técnicas de aplicação de testes de acuidade visual entre professores e diferentes atores sociais para aplicarem em crianças da pré-escola e de primeira série.

Para tanto, tive que contatar os Secretários de Saúde e da Educação daquela cidade para expor o projeto e seus propósitos, bem como a sua metodologia, e verificar o interesse e a disponibilidade do setor saúde, no 
que dizia respeito ao atendimento oftalmológico de crianças com dificuldades detectadas no teste de acuidade visual e a possibilidade de participação do pessoal de enfermagem no treinamento e na execução. Com o pessoal da Secretaria da Educação, foi no sentido de analisar quais seriam os professores que estariam envolvidos no projeto para poder adequar a proposta elaborada. As professoras trabalharam nesse projeto, como voluntárias.

Foi assim que aconteceu minha primeira experiência em construir um projeto, entrar em contato com secretários municipais, conhecer o espaço físico de uma comunidade e a oferta de serviço nela existente, tendo em vista a perspectiva da prevenção precoce de problemas visuais e contando com a participação de diferentes atores sociais.

Esse projeto contou com a colaboração de estudantes do curso de ortóptica, que foram por mim convidados, para participarem com 0 objetivo de adquirirem experiência na área de saúde pública e passarem um fim de semana na cidade. Além daqueles, contou também com algumas pessoas da comunidade, voluntários, com a intenção de triar o maior número possivel de crianças em um único final de semana. Para isso, houve necessidade de uniformizar os conhecimentos básicos de saúde ocular e padronizar a forma de aplicar os testes de acuidade visual, definir quando e como encaminhar as crianças para o médico oftalmologista, o que foi feito mediante treinamentos e reuniões com o grupo de trabalho. Instrumentos foram criados, como: uma ficha de saúde ocular $e$ formulário de encaminhamento para o serviço de saúde na tentativa de documentar o trabalho em seu fluxo de atendimento. 
Durante a execução do projeto, que ocorreu em um final de semana, a Prefeitura local colaborou com a divulgação do projeto, através dos meios de comunicação local: entrevistas publicadas no jornal e levadas ao ar pela emissora de rádio local, com o objetivo de divulgar junto à população o que iria acontecer e convidá-la a levar seus filhos de 3 a $\varnothing$ anos para realização do teste de acuidade visual; além disso, efetuou a doação de material de consumo e cedeu os locais para desenvolvimento do treinamento e realização dos testes.

Essa primeira experiência, na área de saúde pública, com a intenção de envolver diferentes pessoas e tornar possivel a intersetorialidade (na época, não tinha clareza da importância desse conceito), foi por demais enriquecedora. Ainda que apresentando várias lacunas e erros, abriu um espaço para reflexão e reformulação de outros projetos.

Após essa vivência, que infelizmente não foi publicada em nenhuma revista científica (na época não havia despertado ainda para a importância de divulgar trabalhos científicos), surgiu a chance de continuar o estágio de aprimoramento da FUNDAP $e$ iniciar um processo de validação $e$ sistematização do projeto de ações básicas de saúde ocular, no Centro de Saúde da Escola Paulista de Medicina-EPM (atualmente Universidade Federal de São Paulo). Tratava-se de um centro de saúde-escola, portanto, diferenciava-se dos demais, porque servia de campo de estágio para alunos de enfermagem e de medicina em diferentes especialidades, além de prestar serviços à comunidade, como uma unidade básica de saúde mais complexa.

Nesse momento da minha vida profissional, durante a realização desse estágio no Centro de Saúde da Escola Paulista de Medicina, tomei 
conhecimento da existência do curso de Especialização em Saúde Pública na Faculdade de Saúde Pública da Universidade de São Paulo (FSP/USP), que representava a oportunidade de ampliar meus conhecimentos, organizá-los e formalizá-los. Então, decidi prestar o exame de seleção, fui aprovada e freqüentei o curso. Tive a possibilidade de um aprendizado, na minha visão, muito valioso, ampliando o meu acesso ao conhecimento de diferentes áreas disciplinares: a história da saúde pública no Brasil e no mundo, as ciências sociais, a epidemiologia, a bioestatística, a demografia, a educação em saúde; estava de frente com a oportunidade para amadurecer a idéia de um projeto maior.

Na FSP, conheci a atuação de diferentes profissionais - médicos, enfermeiros, engenheiros, fonoaudiólogos, fisioterapeutas - e a sua inserção no setor saúde, observando que todos se respeitavam, independentemente da categoria profissional a que pertenciam. Como trabalho de conclusão do curso, desenvolvi um trabalho de campo em Monte Azul Paulista, SP, em equipe multiprofissional, com o objetivo de realizar um estudo diagnóstico da situação de saúde local; nas reuniões do grupo, durante o planejamento do trabalho, colocava no momento oportuno, a possibilidade de atuação técnica do ortoptista enquanto executor e multiplicador de ações preventivas, além daquelas assistenciais, curativas. Essa foi outra grande chance de ampliar meus saberes teóricos e práticos em saúde pública.

Em paralelo, como estava desenvolvendo o estágio no Centro de Saúde da EPM, com a ampliação de conhecimentos teórico-práticos, pude criar um espaço para colocá-los em prática. Essa foi, para mim, a fase de aprendizado mais intenso, pois, no centro de saúde participava da equipe 
técnica, espaço de trocas de idéias, de opiniões e de críticas construtivas, aprendendo e exercitando a humildade e tendo sempre em mente que o trabalho deve ser realizado com outros e para outros.

Conhecimentos foram agregados e sistematizados. Criei nessa época, com a ajuda técnica da equipe do centro de saúde, um campo de estágic para estudantes de ortóptica, visando proporcionar uma reflexão sobre a atuação do ortoptista e ampliação de seus horizontes de possibilidades. Esse campo de estágio durou três anos, esvaziando-se após minha saída do serviço. Nesse centro de saúde desempenhava atividades de docência para outros cursos, como o de enfermagem e de medicina, onde, além do ensino teórico sobre saúde ocular e técnicas de avaliação da acuidade visual, desenvolvia a parte prática com os alunos, levando-os a realizarem a triagem visual em crianças da própria comunidade, em creches e escolas públicas, localizadas na área de abrangência da unidade.

Essa experiência findou-se com o meu pedido de demissão, após 8 anos de trabalho, como contratada da EPM.

Senti a necessidade de ampliar meus conhecimentos e de amadurecer a idéia de partir para a carreira acadêmica, quando ainda atuava no centro de saúde. Assim, resolvi, em seguida ao curso de especialização, em 1989, ingressar no curso de pós-graduação em Saúde Pública na FSP/USP - nível mestrado, defendendo, mais tarde, a dissertação intitulada: "Assistência à saúde ocular de crianças nos serviços de saúde pública do município de Campinas, 1993-1994".

O trabalho de dissertação teve, como objeto, avaliar os conhecimentos de saúde ocular do pessoal de saúde que trabalhava na unidade no atendimento de crianças de 0 a 7 anos, objetivando mostrar 
que muitas ações que seriam da competência de uma unidade de saúde, não eram executadas por falta de informação dos trabalhadores dos centros de saúde da rede pública de Campinas, São Paulo.

A partir da experiência do mestrado, participei de diferentes congressos de saúde pública, em nível estadual, nacional e internacional, apresentando trabalhos, com o objetivo de divulgar o trabalho profissional do ortoptista e a área de saúde ocular, no contexto da saúde pública.

Em 1992, iniciei na Prefeitura de Campinas um trabalho de consultoria e assessoria na área de saúde ocular, com propósito de planejar, implantar e sistematizar as ações básicas de saúde ocular para os serviços de saúde pública locais, com base nos resultados obtidos na dissertação de mestrado.

Possuía um diagnóstico da situação de saúde ocular no Município, realizado quando do trabalho de mestrado; esbocei com a equipe técnica da Prefeitura uma proposta de projeto, que visava à promoção da saúde ocular e à detecção precoce de problemas visuais, para ser desenvolvida no serviço de saúde e na unidade escolar, com a intenção de apresentá-la aos diretores das unidades de saúde e das escolas, na expectativa de contar com a aprovação para sua implantação. Foi minha primeira experiência de trabalho em um Município, dentro de uma visão de saúde pública e de uma realidade político-institucional.

As propostas para o Município foram mais ambiciosas, incluindo a promoção da saúde ocular, de forma ainda tímida, em que a intersetorialidade e a participação apareciam de forma clara nos objetivos do trabalho. 
Trabalhei muito, sensibilizando atores sociais para a importância da promoção e preservação da saúde ocular e capacitando-os, do ponto de vista teórico-prático, para realização da triagem visual. $O$ processo de capacitação atingiu pediatras e equipes de enfermagem dos serviços de saúde pública de Campinas, além de professores de escolas Municipais, que atuavam com crianças de 0 a 12 anos; para isso, fui conhecer previamente a realidade local das unidades de saúde e das escolas.

Desliguei-me da Prefeitura de Campinas, quando das mudanças políticas do governo local, não tendo tido a oportunidade de avaliar o processo final do trabalho iniciado mas, com a certeza de ter aberto um espaço de reflexão e sensibilização sobre a importância da saúde ocular no contexto da saúde da criança.

Hoje, tenho clareza de que no espaço da saúde pública, o ortoptista sanitarista, junto com outros profissionais, apresenta todas as condições necessárias de participar no processo de produção da saúde, promovendoa e prevenindo problemas, a partir de ações básicas de saúde, o que, certamente, iria redundar em redução gradativa da demanda à assistência curativa, aumentando, com isso, a cobertura da saúde ocular.

O ortoptista não se propõe a proceder ao diagnóstico médico de patologias, com vistas a uma intervenção cirúrgica, corretiva, pois isto não faz parte de sua competência. Porém, saber reconhecer dificuldades visuais e aplicar medidas promocionais e preventivas, assim como identificar casos que requerem intervenção médica e que necessitam ser encaminhados para o profissional especializado, constituem o espaço em que o referido profissional tem a formação necessária para transitar e contribuir para a maior eficácia e eficiência da área de saúde ocular, que 
permanece, na maior parte das vezes, restrita à assistência médica, individual, curativa. É necessário dar um salto de qualidade para se assumir a dimensão de saúde coletiva, dentro de uma perspectiva interdisciplinar $e$ interprofissional, com atuação nos vários niveis de complexidade do sistema de saúde.

Nesta linha, repito, o ortoptista seria um dos profissionais que, juntamente com outros, inclusive médicos, integrariam a equipe de atuação na área de saúde ocular.

Não obstante todo o processo descrito, minhas inquietudes $e$ indagações continuam, agora com uma pequena diferença: estão mais amadurecidas e aprimoradas. Senti necessidade de repensar a minha prática e a de outros atores sociais em relação ao envolvimento em um projeto de ações de saúde ocular, à medida que são previamente determinadas. Em outras palavras, considerei relevante, neste momento, analisar a participação social no processo de construção de um projeto de saúde ocular, na perspectiva de contribuir para a criação de condições para melhoria da qualidade de vida de crianças.

Muitas perguntas povoaram meus pensamentos em relação a essa questão, dentre elas: de que maneira um projeto de saúde ocular possibilitaria a participação de atores sociais de distintas instituições e setores em um processo de construção coletiva? como desenvolver o processo na direção da promoção da saúde? como analisar a participação de atores sociais, de forma a poder reconhecer diferenças, processos coletivos e individuais? a partir de quê parâmetros? 
Creio ser pertinente abrir um espaço para reflexão sobre como é possível desenvolver a participação social em um projeto de uma área da saúde, como a da saúde ocular.

Preocupa-me, neste momento, o processo de construção/ reconstrução de uma prática, a partir da multiplicação de conhecimentos básicos de saúde ocular, com o objetivo de contribuir para 0 fortalecimento individual e coletivo na direção da participação transformadora de uma dada população.

Aqui, finalizo o recorte da história da construção da minha vida profissional e pessoal, razão da aproximação do objeto deste estudo, que não se deveu a um mero acaso, desprovida de intencionalidade, principalmente no que se refere ao desafio da descoberta de novos conhecimentos e de outros caminhos a serem percorridos, à busca de práticas mais comprometidas com a realidade social.

Quero registrar que, no que diz respeito à minha formação, considero que foi fundamental a oportunidade que tive de adentrar no campo da saúde pública, aprender e reaprender, articular conhecimentos de distintas disciplinas e poder colocá-los ao acesso de outros cidadãos e com eles, construir novos conhecimentos.

Este ensaio de atuação do profissional, na ótica da saúde pública é uma forma de estar construindo um espaço condizente com as necessidades atuais, dentro do contexto político-social e avançando teórica e praticamente na área em questão, a partir da minha experiência profissional de mais de 15 anos dentro do setor público. 
A prática da vida foi e está sendo importante para o meu aprendizado,

à medida que posso avaliar, planejar, intervir, encaminhar e devolver.

FREIRE 1997 


\section{2 - INTRODUÇÃO}

A construção de um Projeto de Saúde Ocular, voltado para uma dada população, requer, necessariamente, estar explicitando a concepção de saúde-doença que embasa o mesmo, assim como outros conceitos a ela relacionados, tais como promoção de saúde, prevenção de doenças e participação social, uma vez que se tratam de termos polissêmicos e que podem conduzir a equívocos, quando não esclarecidos devidamente. Por esta razão, ainda que de forma sucinta, reservo um espaço para tal discussão.

O processo saúde e doença está correlacionado com o contexto de vida dos indivíduos, é o resultado das condições em que vivem os seres humanos e fruto da organização social onde estão inseridos; leva em consideração não só a questão da vida, sobrevida, mas também, da existência desses indivíduos.

Ter Saúde é ter acesso a trabalho, moradia com rede de água e esgoto, equilíbrio ambiental, alimentação saudável, poder planejar o futuro, ter amor, enfim, boa qualidade de vida.

Ter saúde é sentir-se bem, ela altera o perfil emocional da pessoa na sua atuação profissional, na sua relação amorosa, é o arcabouço da vida.

Saúde é tudo que nasce com um todo... A dimensão do entender este todo é ampla demais, mas não infinita que não caiba na compreensão do ser humano. Compreensão esta, como o direito de saber, de ser, de falar, de agir e acontecer, enfim, de ser cidadão. 
Com o avanço do conhecimento na área de epidemiologia e das ciências sociais, no âmbito da saúde coletiva, a explicação das causas das doenças não encontra sustentação na dimensão unicamente biológica, dado que saúde-doença passa a ser entendida como um processo biológicosocial.

Para Laurell, em 1983, a explicação da redução das doenças que necessitam de ações específicas de prevenção não pode ser entendida como sendo apenas sucesso do desenvolvimento médico ou biológico, mas sim, resultado das características das formações sociais em cada um dos momentos históricos (LAURELL 1983).

Para a autora, existe uma relação entre processo social e o processo saúde e doença, sendo fator determinante o modo com que cada grupo se insere nos meios de produção e se relaciona com outros grupos sociais.

O impacto da medicina sobre a saúde tem sido pequeno, se comparado com a força da estrutura social como - processo de produção e distribuição, estrutura fundiária (NAIDOO e WILLS 1996).

Nessa perspectiva, planejar ações de promoção significa almejar mudanças nos estilos e condições de vida das pessoas. Trabalhar com o objetivo de promover a saúde é ampliar o horizonte de possibilidades de atuação na busca de melhor qualidade de vida e não apenas reduzi-la às ações curativas.

Faz-se necessário, neste momento, a apresentação breve dos principais aspectos históricos sobre promoção da saúde no mundo e no Brasil, com base em uma revisão bibliográfica, para que se possa situar a perspectiva teórico-metodológica que norteou a construção do Projeto de 
Saúde Ocular. Neste sentido, procura-se resgatar os principais conceitos $e$ ações adotados em relação ao assunto.

\section{1 - Saúde Püblica e Saúde Ocular}

Cabe, neste momento, antes de situar a saúde ocular no espaço da saúde pública, tentar estabelecer a diferença entre visual e ocular, freqüentemente usados como sinônimos, e conduzindo a equívocos. De forma simples e resumida, pode-se dizer que visual está relacionado com visão e o ato de enxergar; ocular engloba a visão, anatomia, fisiologia, enfim, refere-se ao olho, objeto de trabalho dos profissionais da área de oftalmologia, ortóptica, optometria e outras.

Saúde visual é mais amplo, do ponto de vista conceitual, do que o termo saúde ocular, já que este nos reporta a pensar nos olhos, apenas.

O termo utilizado neste trabalho é o de saúde ocular, muito embora se tenha conhecimento que a saúde visual é mais ampla que a ocular. $O$ termo foi eleito para este estudo, tendo em vista a história dos programas oficiais no Brasil, assim denominados: Programa Nacional de Saúde Ocular (PNSO 1984) e Programa Nacional de Saúde Ocular e Prevenção a Cegueira (PNSOPC 1987), adotados pelo Ministério da Saúde, bem como em nível Estadual e Municipal.

Alguns Departamentos de órgãos públicos também adotam esse denominação - Saúde Ocular, como é o caso do Departamento de Saúde Escolar da Sociedade Brasileira de Pediatria. O próprio Ministério da 
Saúde faz referência em seus documentos relativos ao assunto, como programas e projetos de Saúde Ocular (MINISTÉRIO DA SAÚDE 1998).

Feito esse esclarecimento, vale dizer que refletir e atuar em promoção da saúde ocular em um país em desenvolvimento é uma tarefa bastante complexa. Em primeiro lugar, porque não se pretende priorizar uma "parte do corpo", os olhos, já que o indivíduo é uma totalidade, incluindo um corpo, sentimentos, emoções, valores, e que se desenvolve imerso em uma dada realidade social, econômica, política, cultural. Isto implica, portanto, encarar a saúde ocular como parte integrante da saúde, entendida em seu sentido amplo, como processo biológico-social.

Outro pressuposto a considerar é que o indivíduo, cidadão, tem o direito de conhecer e preservar sua saúde ocular, cabendo ao Estado a responsabilidade da atenção e cuidados necessários para que isso ocorra.

Sabe-se que saúde ocular é apenas uma parte da saúde mas, uma das mais importantes.

Basta lembrar que quase $85 \%$ do contato e interação que os seres humanos fazem com o mundo é através da visão. Se se utilizassem técnicas básicas, como simplesmente avaliar a acuidade visual, estar-se-ía colaborando para a redução da cegueira evitável mundial em $70 \%$, segundo estudos de organismos internacionais (THYLEFORS 1987). Além disso, cerca de 20 a $25 \%$ das crianças em idade escolar apresentam algum problema visual e, aproximadamente $95 \%$ desses problemas são passíveis de serem evitados, mediante ações de promoção e de prevenção, dentro de um processo educativo (CBO 1998). Uma criança de 3 anos, que não enxerga de um olho, a título de exemplo, não sabe referir para a mãe o 
que sente, até porque este fato não provoca dores a ponto de se recorrer ao médico.

Mesmo ao ser levada ao serviço de saúde, poderia não contar com profissionais instrumentalizados para tal detecção, situação constatada, com frequiência, por SPERANDIO (1994), em estudo sobre conhecimentos das ações básicas de saúde ocular, revelados por pediatras e enfermeiros de unidades de saúde de Campinas, no qual concluiu que esses profissionais apresentavam poucos conhecimentos a respeito.

Esses resultados, entretanto, não expressam o desejo/vontade de pediatras e enfermeiros de não atuarem nesta área mas, sobretudo, a falta de informação específica durante a formação acadêmica (SPERANDIO 1999a).

Uma outra situação é a de uma criança, portadora de miopia desde tenra idade; se não forem observados os sinais e sintomas que a mesma possa apresentar, pela mãe ou por profissional do serviço de saúde, essa criança, certamente não irá referir que não consegue enxergar de longe, devido ao fato de não ter tido a oportunidade de conhecer visualmente nada diferente daquilo que consegue ver.

É importante ressaltar o baixo custo e alto benefício de trabalhos na perspectiva da promoção da saúde e prevenção, haja vista que é mais oneroso manter uma pessoa portadora de cegueira na sociedade, sob todos os aspectos - econômico, social, emocional - do que gastar com programas educativos e preventivos.

A educação em saúde é um dos instrumentos que vêm sendo privilegiados para efetivação da promoção da saúde, responsabilidade de toda a sociedade e, em particular, de profissionais que integram serviços 
de saúde - médicos, enfermeiros, educadores em saúde, auxiliares e demais profissionais; escolas - professores e auxiliares, e comunidade líderes políticos, religiosos, agentes comunitários.

Entendida a Educação em Saúde desta forma, os objetivos de programas educativos em saúde ocular devem contemplar, também, o acesso à ampliação de conhecimentos, mudanças de atitudes e práticas da comunidade, inclusive, dos serviços públicos, privados e filantrópicos.

Os atores sociais necessitam entender o significado de enxergar, a importância da visão no contexto da saúde, da educação, para assumir e defender a concepção da saúde ocular como direito do cidadão. Esta deveria ser a concepção norteadora na construção de projetos de promoção da saúde ocular.

Parte-se do pressuposto de que toda criança tem o direito de conhecer e preservar sua saúde ocular, exigindo do Estado a atenção e cuidados necessários para mantê-la.

Neste sentido, entende-se que a habilitação do cidadão representa um dos componentes importantes do processo educativo na direção da promoção da sua própria saúde, ao lado de outros componentes de ordem social, em seu sentido amplo, produtores de condições geradoras de saúde/doença.

O pressuposto desta forma de situar a saúde ocular se resume em que uma boa condição de saúde ocular faz parte de uma boa condição de saúde. 


\section{2 - Problemas oftalmológicos mais freqüentes em crianças}

Estudos sobre a incidência e a prevalência de problemas oftalmológicos na população de crianças no Brasil têm se mostrado, na maioria das vezes, tímidos e referentes a populações isoladas.

$\mathrm{Na}$ área de saúde pública desenvolveram-se algumas ações $e$ programas que merecem estar sendo mencionados, antes mesmo de relatar sobre a frequiencia de problemas visuais, para situar o leitor $e$ rever quais as principais atitudes que foram tomadas em relação à saúde ocular no setor público, considerando a ordem cronológica de acontecimentos:

$\checkmark$ A primeira ação do serviço público na área de saúde ocular instilação do nitrato de prata a $1 \%$ no recém nascido dentro de 1 hora após o nascimento - teve seu início em 1935, visando à prevenção da conjuntivite (de etiologia gonocócica), mas foi estabelecida como Norma Técnica apenas em abril de 1977, pelo decre to $n^{\circ} 9713$ (SES 1977);

$\checkmark$ Em 1920, iniciou-se, no Estado de São Paulo, a implementação de ações preventivas contra o tracoma nas escolas públicas locais, 0 que, mais tarde, levou à criação do Instituto do Tracoma na década de 30 (SES 1973);

$\checkmark$ No município de São Paulo foi criado um Departamento de Assistência Escolar, 1967, composto de equipe multiprofissional 
$e$ interdisciplinar, para desenvolver atividades de prevenção $e$ promoção da saúde junto a escolares, inclusive, ações preventivas de saúde ocular, (ARMOND 1998);

$\checkmark$ Em 1971, a Secretaria de Educação e de Saúde do Estado de Sãc Paulo realizou um seminário sobre Problemas Oftalmológicos dos Escolares para orientadores pedagógicos de saúde que atuavam nas escolas estaduais de primeiro grau, (ARMOND 1998);

$\checkmark$ A Sistematização de ações de Oftalmologia Sanitária nas escolas levou um grupo de técnicos das Secretarias de Educação e da Saúde do Estado de São Paulo a elaborar o Plano de Oftalmologia Sanitária Escolar (POSE), que foi aprovado pelo Governo de Estado em 1973. O POSE direcionava ações de promoção da Saúde Ocular e prevenção de problemas visuais para alunos de escolas públicas estaduais, da pré-escola, primeiras e terceiras séries do $1^{\circ}$ grau e de classes especiais. Tinha como objetivos principais: contribuir para o bem-estar do escolar (assistindo-o em seus problemas oftalmológicos), diminuir a incidência de problemas na área e evitar que problemas visuais na infância se tornassem definitivos;

$\checkmark$ Em 1984, um grupo de técnicos do Instituto de Saúde da Secretaria de Estado de São Paulo elaborou um programa piloto de implantação de Ações de Saúde Ocular, o chamado Plano Nacional de Saúde Ocular (PNSO). Este plano definia, em sua 
abordagem teórica, uma assistência mais global ao usuário do serviço de saúde pública. O objetivo geral do PNSO era desenvolver atividades de promoção, proteção e recuperação da saúde ocular, no âmbito da Secretaria de Estado da Saúde, visando minimizar a incidência e prevalência de morbidade visual, prevenindo-se a cegueira (SES 1984);

$\checkmark$ Em 1987, o PNSO passou a ser chamado Programa Nacional de Saúde Ocular e Prevenção a Cegueira (PNSOPC), adotado pelo Ministério da Saúde através da Secretaria Nacional de Programas Especiais de Saúde (MS 1987);

$\checkmark$ Em 1988, o documento PNSO foi reformulado, mas os objetivos e - desenvolvimento metodológico teórico permaneceram semelhantes, adequado, na época, às propostas gerais do Sistema Unificado e Descentralizado de Saúde (SUDS). O PNSOPC apresentava, como objetivo geral, a "promoção, proteção $e$ recuperação da saúde ocular nos diferentes níveis de atenção à saúde e prevenção à cegueira e da incapacidade ocular" (MS 1988);

$\checkmark$ Em 1996, foi alocada uma equipe para desenvolver ações de saúde ocular para cada 10 regiões administrativas do município de São Paulo, após implantação do Plano de Atenção à Saúde: 
$\checkmark$ Em 1998, o Projeto Veja Bem Brasil, voltado para todas as crianças de $1^{a}$ série do primeiro grau, contou com a parceria entre Ministério da Educação e Conselho Brasileiro de Oftalmologia. As professoras receberam um treinamento teórico para realização de triagem em escolares e encaminhamento daquelas que apresentassem problemas visuais para os oftalmologistas integrantes do projeto: mais tarde, em 1999, esses oftalmologistas passaram a receber por consulta realizada; as crianças que apresentavam a necessidade de óculos, estes eram doados (CBO 1998);

$\checkmark$ Em 1999, desenvolveu-se o Projeto Catarata no município de Campinas, iniciativa do Departamento de Oftalmologia da Universidade Estadual de Campinas, em parceria com o Ministério da Saúde, que o estendeu em nível nacional, para pessoas maiores de 50 anos:

$\checkmark$ Em 1999, o Projeto Veja Bem Brasil passou a ser denominado "Olho no Olho".

Atualmente, o PNSOPC, o Projeto Catarata e Olho no Olho integram a política oficial nível de Ministério da Saúde, voltado para a promoção e proteção da saúde ocular do cidadão brasileiro.

Alguns desses projetos e programas citados, na prática, não tiveram continuidade. Desenvolveram-se vinculados a outros interesses que não à 
necessidade do cidadão, alheios ao desejo de saber da população, que permaneceu sem nada conhecer de saúde ocular.

A importância de se promover a saúde ocular de crianças e de se prevenirem precocemente problemas visuais foi e tem sido descrita por diferentes autores, destacando-se: KARA-JOSÉ (1984a;c); OLIVEIRA, CUNHA (1988); SPERANDIO (1994); TEMPORINI e KARA-JOSÉ (1995): KARA-JOSÉ e ALVES (1996).

Newton Kara-José e Oswaldo Monteiro de Barros merecem destaque, na área de saúde ocular voltada para o setor público, uma vez que eles têm sido uns dos poucos oftalmologistas que, durante a vida profissional, atuaram, dedicaram e se preocuparam, dentre outras iniciativas, com propostas inclinadas para a saúde pública. $E$, principalmente, por trabalharem em equipe, atuando em seus projetos com diferentes profissionais (médicos, enfermeiras, professoras) na prevenção da cegueira.

Oswaldo Monteiro de Barros participou da elaboração do POSE, em 1971, e foi um dos responsáveis pela elaboração e implantação do PNSO, a partir de 1984.

Newton Kara-José, atualmente, é um dos responsáveis pela elaboração e implantação/execução do Projeto Catarata, dirigido a adultos maiores de 50 anos, e do Projeto Olho no Olho, que acontece anualmente, voltado para crianças de primeira série do Ensino Fundamental, em Municípios espalhados pelo Brasil, em parceria com o Ministério da Educação e com o Conselho de Oftalmologia, como foi referido em parágrafos anteriores. 
Projetos de Saúde Ocular de maior abrangência, voltados para a saúde pública, contaram, sempre, com a participação direta ou indireta de Dr. Newton Kara-José, seja na coordenação, seja na articulação de parcerias.

É um dos autores freqüentemente citados nessa área, devido à sua produção científica e à sua experiência profissional.

É importante ressaltar, em relação aos projetos apoiados $e$ desenvolvidos por esse autor, que grande parte deles é de cunho preventivo e curativo, privilegiando parcelas da população - especialmente os escolares. A limitação desses projetos, na leitura desta pesquisadora, refere-se à não inclusão de crianças que se encontram no período em que ocorre o desenvolvimento visual ( 0 a 7 anos) e que estão fora da escola, ou idoso - que tem grande probabilidade de apresentar algum problema ocular.

É compreensivel a necessidade imediata de priorização de faixa etária, inserção social, como população-alvo, quando se defronta com os recursos disponíveis (escassos) na área de saúde ocular; porém, há que se considerar a população como um todo, assim como as especificidades do processo de desenvolvimento ocular no contexto do desenvolvimento humano; ao mesmo tempo, o reconhecimento da saúde ocular como direito do cidadão, se se quiser trabalhar na perspectiva da prevenção e até mesmo da promoção da saúde.

A necessidade de desenvolver programas de promoção da saúde ocular é emergente e muito alertada por alguns autores, entre eles, SPERANDIO (1990): SPERANDIO (1999a): TEMPORINI e KARA-JOSÉ (1995); TEMPORINI (1998). Hoje, a situação corresponde a iniciativas de 
triagens visuais em escolares e idosos, e, às vezes, à solução curativa, diante de problemas detectados.

Um panorama global da situação mundial da cegueira foi apresentado, em 1995, pela Organização Mundial de Saúde (OMS), que concluiu que a Carga Mundial de Incapacidade Visual (CMIV), entre as pessoas cegas e aquelas com perda visual importante, atingia cerca de 148 milhões de individuos. Destes, 58\% (21 milhões) tinham idade de 60 anos e mais, $31,7 \%$ (12 milhões), entre 45 e 59 anos, 6,5\% (2.5 milhões), entre 15 e 44 anos e 3,8\% (1.4 milhões) eram menores de 15 anos (THYLEFORS 1995).

Pensando-se em ação imediata, grande parte das preocupações vem sendo em torno da faixa etária maior de 60 anos, alicerçada em um estudo da OMS, que revela que $42 \%$ das causas de cegueira mundial são devidas à catarata, problema ocular passível de solução, mesmo depois de cego, e que acomete pessoas idosas (THYLEFORS 1995).

Dados da Pesquisa Nacional sobre Saúde e Nutrição (PNSN), em 1989, revelaram 128.423 pessoas com cegueira total e 4.712 .389 pessoas com cegueira parcial (In: MINISTÉRIO DA SAÚDE 1997)

Reconhece-se a importância de dados epidemiológicos de incidência e prevalência de problemas visuais mais freqüentes na população geral, que ajudam a direcionar ações específicas a problemas e a seus portadores $e$ faixas etárias correspondentes; entretanto, há que se considerar que, dentro de um conceito ampliado de saúde, portanto, contemplando ações não só no nivel curativo, mas sobretudo na perspectiva da promoção da saúde e na prevenção precoce de problemas, no âmbito da saúde pública/saúde coletiva, uma outra lógica se faz necessária para o planejamento/programação de ações de saúde ocular. 
O comportamento psicológico da criança pode ficar alterado se ela apresentar dificuldades visuais, e o seu rendimento na escola ficar deficiente (LAURETTI e ROMÃO 1982: THYLEFORS 1995).

O POSE (SES 1973) registrou que $25 \%$ dos escolares apresentavam problemas visuais, sendo que: $18 \%$ apresentavam ametropias (erro refracional, necessidade de óculos): $7 \%$, tinham outros problemas, como conjuntivite, estrabismo e outras perturbações.

A ambliopia ${ }^{1}$ é um outro distúrbio ocular, citada na bibliografia, de importância em crianças, considerada como passivel de controle para evitar a cegueira (THYLEFORS 1995): quanto mais precocemente for diagnosticada, melhores serão os resultados da recuperação da quantidade e qualidade de visão com tratamento adequado, se assim ocorrer antes dos 8 anos de idade.

Para isto, é necessária a aplicação dos testes de acuidade visual periodicamente, ao nascimento, aos 8 meses, aos 3 anos e aos 6 anos, como sugere CAMPOS (1995).

A prevalência de ambliopia, no Brasil, é de 2 a $4 \%$, segundo as referências bibliográficas nacionais (COSTA e col. 1979; KARA-JOSÉ e col. 1984a; 1984c: KARA-JOSÉ, CARVALHO e col. 1984b; SCARPI 1977: TEMPORINI e col. 1983).

O campo de estudo sobre prevalência de problemas oculares no Brasil apresenta um hiato nas informações, no que diz respeito ao que considerar como objeto de estudo e em qual região do País; o importante

\footnotetext{
${ }^{1}$ Ambliopia é a redução de visão em um olho ou em ambos por falta de estimulação adequada e precoce (antes dos 8 anos, porque é nesta idade que se completa o desenvolvimento visual), provocada por estrabismos, anisometropias (diferença de grau de um olho para outro) $e$ hipermetropias.
} 
é que se torne uma preocupação, não só de autoridades governamentais, como da sociedade.

\section{3 - A concepção e construção da Promoção da Saúde no Mundo - principais referenciais históricos}

Ao se estudarem os principais conceitos utilizados durante os últimos 50 anos sobre promoção da saúde, observa-se que eles evoluíram, em paralelo ao entendimento intrínseco do processo saúde-doença que, por sua vez, agregou novas perspectivas com o desenvolvimento científico da epidemiologia.

Muitos foram os pesquisadores que escreveram e reescreveram sobre promoção de saúde, porém neste trabalho serão citados apenas alguns, utilizando-se, como critérios, a ordem cronológica, o impacto dos documentos no mundo e aqueles estudos que colaboraram para os subsequientes, fazendo aumentar o poder de entendimento de quem iria aplicá-los na prática.

Uma das primeiras definições de promoção de saúde data dos anos 20, com Winslow (1920-1923), citado por CERQUEIRA (1997), que referia que a comunidade organizada poderia obter políticas que promovessem as suas condições de saúde e nesse sentido, valorizava a existência de programas educativos para o indivíduo melhorar sua saúde, desenvolvendo-se assim, uma máquina social que assegurasse a sua manutenção e promoção, enfatizando a importância da educação em saúde. 
Apesar de não considerar as diferenças sociais, sem dúvida, é uma definição ampla para o contexto político dos anos 20.

Já em 1941-1946. Henry Sigerist, médico historiador, propõe que a promoção da saúde se ja uma das quatro tarefas básicas da medicina, quais sejam: promoção da saúde, prevenção da doença, restabelecimento do doente e a reabilitação.

Sigerist ressaltava a importância da interação entre estadistas $e$ líderes de trabalho, da indústria, da educação e dos médicos. Para o autor, a promoção da saúde seria viável quando existisse "um nível de vida decente, com boas condições de trabalho, educação, cultura física, descanso e recreação" (In: FERRAZ, 1998).

Para LEAVELL e CLARK (1970), a promoção de saúde constitui o primeiro nível de prevenção; associa-se o conceito de promoção com o de prevenção.

Com o objetivo de projetar a área da saúde e redefinir seus paradigmas, a Organização Mundial de Saúde (OMS) e a Organização Panamericana de Saúde (OPAS) realizaram diversas Reuniões e Conferências, em diferentes locais do mundo, ao longo desses aproximadamente 20 anos, divulgando, através de documentos oficiais, os resultados para os Países.

$\mathrm{Na}$ década de 70 , alguns documentos como o de Marc Lalonde, "A New Perspective on the Health of Canadians" (1974), e a Declaração de Alma Ata, OMS 1978, apresentaram a análise das condutas e comportamentos que afetam a saúde, problemas e necessidades de saúde, bem como as políticas de desenvolvimento econômico e social em países desenvolvidos e em desenvolvimento. Inferiam que os investimentos 
realizados na atenção médico-curativa, juntamente com a pouca capacidade de resolução no enfrentamento das doenças crônicas degenerativas, foram o motivo da crise institucional nos países desenvolvidos (In: CERQUEIRA 1997).

Segundo Lalonde, epidemiologista canadense (1974), a redução dos indicadores de mortalidade infantil e aumento da esperança de vida dependem da inserção social dos indivíduos, mais do que do acesso universal aos serviços de saúde ou da organização dos cuidados médicos: em um de seus documentos menciona "...parece-nos evidente, portanto, que vultosas somas de dinheiro estão sendo gastas erroneamente somente para tratar as enfermidades e não para prevení-las efetivamente" (Lalonde 1974; In: OPAS 1994).

Para o autor, o conceito de promoção de saúde vinha sendo traduzido como medidas preventivas e, assim, apresentou cinco estratégias para se trabalhar com a prevenção: promoção da saúde, regulamentação, investigação, cuidado eficiente e estabelecimento de objetivos (FERRAZ 1998).

A Declaração de Alma Ata - OMS (1978), ratificou saúde como sendo um estado de completo bem estar físico, mental e social, reconhecendo a saúde como objetivo social importante, proporcionando novos caminhos para as políticas de saúde e delineando a importância da participação comunitária e a cooperação entre diferentes setores da sociedade.

Com esse propósito, fez-se necessária uma abor dagem que abarcasse a justificativa e a metodologia, capaz de explicitar o por quê e que desse conta de métodos e estratégias para o desenvolvimento prático da promoção de saúde, a partir da adoção de um paradigma para explicar o 
processo saúde-doença, da perspectiva ampliada, em sua determinação biológico-social e não somente do ponto de vista clínico-assistencial.

Na busca de elaboração de novos conceitos e princípios de promoção de saúde, segundo esse novo paradigma para a saúde, um grupo de trabalho da Organização Mundial da Saúde, em 1984, discutiu e referiu que a promoção da saúde representa uma estratégia entre pessoas e o seu ambiente, resumindo-se à responsabilidade da escolha pessoal e social para se criar um futuro saudável. E que "promoção da saúde é um processo de capacitação de pessoas para aumentar o controle sobre sua saúde e melhorá-la" (WHO 1984).

Essas concepções foram discutidas e analisadas na Primeira Conferência Internacional sobre Promoção da Saúde em Ottawa, em 1986. "Saúde para todos no ano 2000" (WHO 1984), tomando como base as condições e necessidades de saúde dos países desenvolvidos da Europa e da América do Norte.

A Carta de Ottawa definiu promoção da saúde como: processo de capacitação da comunidade para atuar na melhoria da sua qualidade de vida e saúde, incluindo uma maior participação no controle deste processo e para atingir um estado de completo bem estar físico, mental e social, os individuos e grupos devem saber identificar aspirações, satisfazer necessidades e modificar favoravelmente o ambiente (WHO 1986).

Esse documento tornou-se marco para estudiosos da área. Ampliou o conceito de promoção da saúde, adicionando a importância do impacto social, econômico, político e cultural, propondo estratégias intersetoriais, como: estabelecer políticas públicas saudáveis, criar meios favoráveis, 
reforçar a ação comunitária, desenvolver atitudes pessoais, reorientar os serviços de saúde (CERQUEIRA 1997; FERRAZ 1998; NUTBEAM 1998).

Muitas das atividades de promoção da saúde, que eram consideradas de responsabilidade individual sobre a conduta, hábitos $e$ comportamentos, passaram a ser criticadas por não considerarem as condições econômicas e sociais, que podem influenciar decisões e ações das pessoas.

É no interior desse movimento, ao final dos anos 80 , que a Saúde Pública é repensada, buscando novos caminhos e chegando ao conceito da "nova Saúde Pública", segunda o qual, novos atores sociais passam a ter expressão nesse esforço coletivo: as agências voluntárias, cujo espaço diz respeito à identificação e atuação nas implicações de saúde no interior de todas as políticas públicas - agricultura, transporte, segurança, desenvolvimento econômico, emprego, moradia, educação e lazer (NAIDOO e WILLS 1996).

Para membros da Organização Mundial de Saúde, a nova Saúde Pública está sustentada por três esferas de ação: a política, a social e a saúde pública. Essas três esferas devem interagir como estratégias para transformação da sociedade, (LABONTE 1994; WHO 1997).

Prosseguindo na busca de instrumentos a serem utilizados no processo da efetivação da promoção da saúde, delineando um novo paradigma, foi realizada, em 1988, na Austrália, uma outra conferência, em que foi elaborada a Declaração de Adelaide, a qual priorizou as "políticas públicas saudáveis, a equidade e com o compromisso do impacto de tais políticas sobre a saúde da população", ressaltando a importância 
de se realizarem novas parcerias na saúde (MINISTÉRIO DA SAÚDE 1986).

Na década de 80, a metodologia mais utilizada para se trabalhar com a promoção da saúde dizia respeito às intervenções, que objetivavam a mudança de comportamento e estilos de vida, através de campanhas, utilizando-se os meios de comunicação - televisão, rádio, imprensa - $e$ material como folhetos, camisetas e outros; porém, os custos desses trabalhos eram muito altos e os resultados, pequenos (CERQUEIRA 1997: FERRAZ 1998).

O'DONNELL (1989), importante estudioso americano sobre o assunto, definiu a promoção da saúde e a condição ótima em saúde, nos seguintes termos:

"Promoção da saúde é a ciência e a arte de ajudar pessoas a mudarem seus estilos de vida e a se moverem na direção do estado ótimo em saúde. O estado ótimo em saúde é definido como um balanço físico, emocional, social, espiritual e intelectual. Segundo o autor, a mudança do estilo da vida pode ser facilitada através da combinação de esforços para aumentar a percepção, mudar 0 comportamento e criar ambientes que amparem bons hábitos de saúde. Dos três, o amparo ambiental provavelmente terá grande impacto produzindo duradouras mudanças" (preface, p. xi).

Em 1991, em Sundsvall, Suécia, realizou-se a terceira Conferência Internacional sobre Promoção da Saúde, em que se explicitou a importância do ambiente para a saúde, ao afirmar que: ambientes e saúde 
são interdependentes e inseparáveis. Atingir estas duas metas deve ser o objetivo central ao se estabelecerem prioridades para o desenvolvimento $e$ devem ter precedência no gerenciamento diário das políticas governamentais (MINISTÉRIO DA SAÚDE 1996).

Bogotá (Colombia 1992) foi a sede da Conferência Internacional de Promoção da Saúde, trazendo para a América Latina a discussão do tema, apresentando-a como um desafio para os governantes dos Países membros, devido às dificuldades que estes vinham enfrentando com a deteriorização das condições de vida da população (MINISTÉRIO DA SAÚDE 1996: In: CERQUEIRA 1997).

Em sua Carta descrevem as orientações para a execução da promoção da saúde, enfatizando a necessidade de "transformar as relações excludentes, conciliando interesses econômicos e propósitos sociais de bem estar para todos", considerando cuidadosamente e analisando a relação entre o contexto econômico e social com o desenvolvimento da saúde, (Ministério da Saúde 1996; In: FERRAZ 1998).

A partir dessa reunião, em 1993, a OPAS aprovou, em seu Conselho Diretivo, o propósito de formular um "Plano de Ação para a promoção da saúde nas Américas", tendo, como objetivo principal, propor a redução das desigualdades sociais, (Ministério da Saúde 1986: In: CERQUEIRA 1997).

GREEN (1992) ressaltou a importância do conceito abrangente de saúde, adotado no Canadá, em relação à qual é assinalada, ao lado da responsabilidade do Estado, também a responsabilidade coletiva da sociedade, no que diz respeito à saúde dos indivíduos.

Esse autor defende a estrutura de planejamento do modelo "PRECEDE", "Predisposing Reinforcing and Enabling Causes in Educational 
Diagnosis and Evolution", que situa "a predisposição, o reforço e a capacidade de construir o diagnóstico e a avaliação educacional", como elementos fundamentais para um trabalho na linha da Promoção da Saúde. (GREEN 1992, p. 26).

Esse modelo enfatiza a importância de situar as ações técnicas no contexto político, mediante regulamentação e organização das ações, objetivando contribuir para a promoção do desenvolvimento educacional e ambiental, na condição de intervenções necessárias para tornar o sistema social e ambiental mais saudável (GREEN 1992).

Desta forma, os métodos para o "desenvolvimento do planejamento da promoção da saúde devem ter como base a participação e divisão de responsabilidades entre os individuos, famílias, profissionais, organização pública ou privada, agências nacionais ou locais", (GREEN 1992).

Em outras palavras, para esse autor, a promoção da saúde é viabilizada pela educação em saúde, que direciona o indivíduo à necessidade de compreensão organizacional, econômica e do meio ambiente, condição fundamental para a busca de novos caminhos e ações, com vistas a elevar a saúde a outro patamar, o que equivale dizer, melhorar a sua qualidade de vida.

Reforçando essa forma de encarar a questão, HARRIS (1992) ressalta que na promoção da saúde é importante considerar o apoio ambiental e social, por constituirem condição necessária para o desenvolvimento de percepções, conhecimentos, habilidades e suporte interpessoal para mudança de comportamento pessoal.

Nesse sentido, ações voltadas à promoção trazem benefícios para a saúde, uma vez que mantêm a promessa de redução da responsabilidade da 
doença sobre a saúde, possibilitando reduzir custos com os cuidados médicos e melhorando a saúde (HARRIS 1992).

Labonte, em vários artigos publicados desde 1987, aborda a promoção da saúde, como algo concreto e factivel, que depende de esforços conjuntos entre todos os atores sociais de um determinado espaço físico; contribui, a partir de seus relatos, para a teoria e prática da promoção da saúde, abrindo um leque de sugestões para 0 desenvolvimento de ações concretas (LABONTE 1994).

No mesmo ano citado, esse autor destacara a relevância da educação popular para a participação ativa dos cidadãos nas relações de poder.

Em 1994, Labonte relata os esforços que vinham sendo despendidos $e$, ao mesmo tempo, as diferentes barreiras para transformar o marco conceitual e a prática da educação em saúde para a promoção de saúde, dentro de um enfoque democrático-participativo: neste enfoque, o conceito de "empowerment" ganha força, assentado na conviç̧ão de que as pessoas têm capacidade de tomarem decisão e agirem individual $e$ coletivamente para defesa dos seus interesses. Assim, o autor ressalta a importância do enfoque participativo da população para aumentar o seu poder de interferir nos processos decisórios, a partir de sua conscientização dos problemas econômicos, políticos e sociais que, em diferentes momentos, determinam as condições de saúde (LABONTE 1994: 1998 a).

O "empowerment", em promoção da saúde, é um processo em que as pessoas adquirem controle sobre suas decisões e ações direcionadas a determinantes da saúde (NUTBEAM 1999, p. 354). Por sua vez, VASCONCELOS (2001) dá um sentido de "aumento do poder pessoal e 
coletivo de individuos e grupos sociais nas relações interpessoais $e$ institucionais, principalmente daqueles submetidos a relações de opressão e dominação social".

NAIDOO e WILLS (1996) referem-se à promoção da saúde como todas as intervenções que promovem a saúde, inclusive a educação em saúde. Mediante trabalho de revisão da literatura, buscam organizar $e$ sistematizar contribuições diversas na área de promoção da saúde, identificando as diferentes abordagens/modelos conceituais, que vêm orientando as práticas na área, assim como o alcance e limitações correspondentes. O quadro abaixo esquematiza as diferentes abordagens: 
Quadro 1. Abordagens em promoção da saúde:

\begin{tabular}{|c|c|c|c|}
\hline ABORDAGEM & OBJETIVOS & MÉTODOS & $\begin{array}{c}\text { RELAÇÃO } \\
\text { TRABALHADOR/CLIENTE }\end{array}$ \\
\hline MÉDICA & $\begin{array}{l}\text { Identificar os } \\
\text { riscos de doença }\end{array}$ & $\begin{array}{l}\text { Consulta no nível } \\
\text { primário }\end{array}$ & $\begin{array}{l}\text { Líder é o especialista } \\
\text { /técnico e o cliente é } \\
\text { passivo e conformado }\end{array}$ \\
\hline $\begin{array}{l}\text { MUDANÇA } \\
\text { DE } \\
\text { COMPORTAMENTO }\end{array}$ & $\begin{array}{l}\text { Encorajar os } \\
\text { individuos a se } \\
\text { responsabilizarem } \\
\text { por sua própria } \\
\text { saúde e a } \\
\text { escolherem estilos } \\
\text { de vida saudóvel }\end{array}$ & $\begin{array}{l}\text { Aconselhamento } \\
\text { individual, } \\
\text { informações, } \\
\text { campanhas }\end{array}$ & $\begin{array}{l}\text { Líder é o especialista e o } \\
\text { cliente é dependente }\end{array}$ \\
\hline EDUCACIONAL & $\begin{array}{l}\text { Aumentar o } \\
\text { conhecimento e } \\
\text { habilidades sobre } \\
\text { estilo de vida } \\
\text { saudável }\end{array}$ & $\begin{array}{l}\text { Formação de } \\
\text { atitudes, mediante } \\
\text { o desenvolvimento } \\
\text { de habilidades em } \\
\text { pequenos grupos } \\
\text { de trabalho }\end{array}$ & $\begin{array}{l}\text { O lider pode ser } \\
\text { especialista. Pode envolver } \\
\text { o cliente nas negociações } \\
\text { dos resultados das } \\
\text { discussões }\end{array}$ \\
\hline EMPOWERMENT & $\begin{array}{l}\text { Trabalhar com } \\
\text { clientes/ } \\
\text { comunidades com } \\
\text { base em suas } \\
\text { necessidades } \\
\text { sentidas }\end{array}$ & $\begin{array}{l}\text { Proteção, } \\
\text { negociação, } \\
\text { divulgação, } \\
\text { facilitação }\end{array}$ & $\begin{array}{l}\text { O promotor de saúde é } \\
\text { facilitador. O cliente } \\
\text { torna-se fortalecido. }\end{array}$ \\
\hline MUDANÇA SOCIAL & $\begin{array}{l}\text { Registrar as } \\
\text { diferenças em } \\
\text { saúde, em termos } \\
\text { de Classe, raça, } \\
\text { geografia }\end{array}$ & $\begin{array}{c}\text { Envolvimento de } \\
\text { política } \\
\text { governamental }\end{array}$ & $\begin{array}{c}\text { Estabelecimento de } \\
\text { vínculo social de baixo } \\
\text { para cima }\end{array}$ \\
\hline
\end{tabular}

Extraido e adaptado de NAIDOO e WILLS: Health Promotion, Foundations for practice; 1996.

Em todo esse processo, a IV Conferência Internacional de Promoção da Saúde, em Jacarta, em 1997, foi a primeira a incluir o setor privado como possível parceiro para a promoção da saúde. Reafirma em seu 
documento final que a ...promoção da saúde é um investimento valioso, é um processo para permitir que as pessoas tenham maior controle sobre sua saúde e para melhorá-la: a promoção da saúde, mediante investimentos e ações, atua sobre os determinantes de saúde, para assegurar direitos humanos e para a formação de capital social. A sua meta primordial é aumentar as expectativas de saúde... A saúde é um direito fundamental e essencial para o desenvolvimento social e econômico (MINISTÉRIO DA SAÚdE 1997).

Nessa Conferência, cinco prioridades foram estabelecidas para a Promoção da Saúde para o século XXI: promover a responsabilidade social para com a saúde; aumentar o investimento para fomentar a saúde: consolidar e expandir as parcerias; aumentar a capacidade comunitária e dar direito de voz ao indivíduo e conseguir uma infra-estrutura para a promoção da saúde, (WHO 1997: MINISTÉRIO DA SAÚDE 1997; WESTPHAL 1998).

Após a Conferência em Jacarta, Kickbusch (WHO 1997) fêz a seguinte consideração: "Nesta época de escassos recursos de saúde pública, a promoção da saúde pode mudar o estilo de vida e ter um impacto significante sobre as condições sociais, econômicas e ambientais que determinam a saúde" (p.241).

Atualmente, vem-se observando a preocupação intensa de alguns autores em não apenas estar definindo a promoção da saúde mas, também, estar traçando caminhos para colocá-la em prática, considerando a interação de diferentes áreas do conhecimento, interação esta que contribuiu para o desenvolvimento de diferentes abordagens e modelos de intervenção em uma comunidade. 
GILLIES (1998) e LABONTE (1998a) destacam a relevância de parcerias entre os sistemas de saúde e outros grupos comunitários, que atuam na área econômica e ambiental, a título de exemplo, como meio para conferir maior eficiência e eficácia às ações de promoção da saúde.

NUTBEAM (1998), Austrália, define a promoção da saúde como um processo de capacitação das pessoas para aumentar o controle sobre sua saúde e melhorá-la. Apresenta uma proposta de planejamento de promoção da saúde e o ciclo de evolução do processo, indicando os vários estágios do trabalho, assim formulados: definição de problemas e prioridades, soluções, mobilização de recursos, implementação e avaliação dos resultados.

Para esse autor, existem teorias para subsidiar o trabalho, visando à mudança de comportamento individual, de pessoas que estão expostas a fatores de risco que podem afetar a sua saúde, mostrando que é possível, a partir do entendimento de caminhos que melhorem a qualidade de vida, mobilizar positivamente a comunidade, influenciando-a sobre a questão saúde-mobilização comunitária, "community mobilization", (NUTBEAM 1998, p.35).

Para ele, dependendo do tipo de problema, definido em conjunto com comunidade, muitas vezes é possível e apropriado associar diferentes modelos e teorias para atingir os objetivos das ações de promoção da saúde.

A V Conferência de Promoção da Saúde, no México em junho de 2000 , teve como tema "Health Promotion: Bridging the Equity Gap" com três principais objetivos (WHO 2000): 
- Mostrar como a promoção da saúde faz diferença para a saúde e para a qualidade de vida, especialmente para pessoas que vivem em circunstâncias adversas:

- Situar a saúde no desenvolvimento da agenda internacional, nacional e de agências locais;

- Estimular as parcerias da Saúde com diferentes setores e em todos os níveis da sociedade.

Os autores, até aqui mencionados, com suas contribuições permitem a visualização do estado da arte dessa área temática, revelando que a produção de conhecimento tem sido mais intensa em regiões e países em que a prática da promoção da saúde tem-se desenvolvido com maior ênfase: Europa Ocidental, Canadá e Estados Unidos da América.

Segundo opinião de CERQUEIRA (1997), na América Latina e Caribe, o processo de desenvolvimento de promoção da saúde tem enfrentado certa resistência por parte dos funcionários da saúde. As ações de promoção da saúde continuam, em muitos países, centradas na atuação com indivíduos, priorizando a cura e prevenção da doença, limitadas à atuação do médico.

\section{A promoção da saúde no Brasil - principais marcos históricos:}

No Brasil, o movimento de promoção da saúde está sendo construído lentamente, em diferentes espaços e por diferentes instituições, organizações governamentais e não governamentais e outros atores sociais. Propostas têm sido elaboradas na perspectiva da promoção da saúde, nas quais tem sido destinado à educação em saúde um espaço 
privilegiado no cenário da saúde pública (WESTPHAL 1999: CZERESNIA 1999).

A prática observada não condiz com o discurso da promoção da saúde em alguns países que vêm avançando na área em questão, em que a educação em saúde faz parte do processo de construção da promoção da saúde, como instrumental essencial que articula esforços de várias áreas, (social, econômico, política) e não como um meio isolado, tal como vem se apresentando de modo predominante no Brasil.

O discurso da promoção da saúde, no Brasil, está sendo construído no interior da história da educação em saúde que, por sua vez, apresenta diferentes fases em seu desenvolvimento. Assim, no início do século, vivenciou a fase epidemiológica, utilizando campanhas informativas para prevenir doenças (LIMA e CAMPOS 1997).

CZERESNIA (1999) é contundente na idéia de que é importante estar explicitando claramente as definições de promoção e prevenção para não se esbarrar na abordagem tradicional de prevenção que se limita a controlar a transmissão de doenças infecciosas e reduzir o risco de doenças degenerativas ou outras doenças específicas. Projetos de prevenção e educação em saúde são estruturados através dos conhecimentos específicos e recomendações normativas para mudança de hábitos (p. 704).

Dando continuidade ao processo histórico da promoção da saúde no Brasil, verifica-se que, a partir de 1920, as ações educativas caracterizavam-se pelos bons hábitos de higiene, enfatizados pelo modelo higienista da saúde pública, dominante naquela época. 
Durante a Segunda Guerra Mundial, nos anos 40, ocorreu um movimento de interiorização da Amazônia para extração de matéria prima, quando se verificaram as péssimas condições de vida da população, que requeriam a criação de mecanismos para alterar essa situação (LIMA e CAMPOS 1997).

Criou-se, então, o Serviço Especial de Saúde Pública, inspirado no modelo norte-americano, em que a ação educativa em saúde trazia, de uma forma intrínseca, o desenvolvimento da ação comunitária e a introdução de novos recursos metodológicos.

Com a criação da Organização Mundial de Saúde (OMS) em 1948, a educação em saúde passou e ter um significado relevante e a ser reconhecida no Brasil, sob a denominação de educação sanitária.

Assim é que o Instituto de Higiene da Faculdade de Medicina da USP, hoje, Faculdade de Saúde Pública, desde 1925, ministrava o curso de educação sanitária para professores do nível básico, para atuarem na rede pública de serviços de saúde. Esse curso sofreu uma interrupção na década dos 60, visando algumas mudanças, sendo reaberto como curso de educação em saúde, em 1967, desta feita, voltado para profissionais nãomédicos, com formação de nível superior.

Com o regime político autoritário dos anos 70, a educação em saúde passa a assumir uma postura tecnicista e autoritária, elaborando plane jamentos normativos, verticais, bastante centralizados, valorizando os recursos tecnológicos (LIMA e CAMPOS 1997).

Ao final de 1975, iniciando-se a fase de reabertura política, num contexto de crise econômica, o setor saúde buscava alternativas mais econômicas e de alcance coletivo para fazer frente à crise do sistema 
previdenciário, principal financiador do sistema de saúde. Nesse contexto, programas de interiorização de ações de saúde passaram a ser desenvolvidos. Verifica-se, nesse período, a atuação intensiva da igreja católica em ações sociais, cresce o movimento sindical.

Faz parte das décadas dos anos 70 e 80 o processo de discussão sobre uma política nacional de saúde, contemplando um sistema único, descentralizado e com atendimento universalizado. Ao mesmo tempo, o exercício da cidadania e da defesa dos direitos individuais também se expressa na educação em saúde, a partir da atuação de um grupo de educadores em saúde, comprometidos com o processo de mudança.

Como decorrência desse processo, a primeira referência oficial à promoção da saúde, como integrante do discurso da saúde aparece no Relatório da VIII Conferência Nacional de Saúde em 1986, a partir da adoção de um conceito de saúde-doença, como processo social, portanto, abrangente e dentro de um paradigma distinto daquele que o circunscreve no âmbito biológico (CZERESNIA 1999: MINISTÉRIO DA SAÚDE 1986).

Faz-se necessário citar alguns acontecimentos que marcaram $e$ influenciaram a história da educação em saúde e da promoção da saúde no Brasil, segundo alguns autores (LIMA e CAMPOS 1997; FERRAZ 1998):

- Conferência de ALMA-ATA, em 1978, sobre a atenção primária em saúde que preconizava os cuidados primários utilizando técnicas simples, valorizando equipes multiprofissionais e preparação de agentes de saúde:

- VIII Conferência Nacional de Saúde, em 1986, que teve representantes de diferentes setores da sociedade, em que se elaborou um documento e que mais tarde, em 1988, foi base para a 
Constituição Brasileira no capítulo da saúde, referente ao seu conceito e como direito universal de cidadania, resultado das condições de saúde e trabalho:

- I Conferência Internacional de Promoção da Saúde, em 1986, em Ottawa, Canadá, quando se resgata a proposta maior de promoção e reafirma, mostrando caminhos, a mudança de paradigma em relação à saúde:

- Instituição e regulamentação do Sistema Único de Saúde, que segundo suas premissas deveria se articular com diferentes setores da sociedade para melhorar as condições de saúde:

- Movimento ambientalista no Brasil que se difunde na década de 80 e se intensifica com a ECO 92 (Conferência Mundial sobre o Meio Ambiente), Rio de Janeiro, em cujo interior a educação enfatiza a relação do homem com o meio ambiente, no sentido de melhorar a qualidade de vida.

Para WESTPHAL (1999), a visão de saúde, preconizada pela Carta de Ottawa, aproxima-se do conceito de saúde formalizado na VIII Conferência Nacional de Saúde em 1986. Em seu entender:

"O grande desafio a que se propõe a promoção da saúde no Brasil, é de transformar as relações excludentes, através de uma estratégia de trabalho intersetorial que concilie interesses econômicos e bem estar social, condições indispensáveis para a saúde $e$ desenvolvimento..." 
O próprio Ministério da Saúde incorporou ações de promoção da saúde em 1996, com o Programa de Informação, Educação e Comunicação (IEC), da Secretaria de Políticas de Saúde, intitucionalizando-as.

Em função disso, programas como: Alimentação, Controle do Câncer, Saúde da Familia, Agentes Comunitários, passam a apresentar fortes componentes da promoção da saúde (WESTPHAL 1999).

Nesse sentido, os municípios foram considerados como um espaço viável para o desenvolvimento de ações de promoção da saúde, levando-se em conta a questão da descentralização administrativa das atividades em saúde e a participação comunitária. Seriam considerados municípios saudáveis aqueles que se engajassem no processo de desenvolvimento de ações de promoção (MENDES 1998).

- Conselho Nacional de Secretários da Saúde (CONASEMS) mostrou-se interessado em implementar ações de promoção da saúde em diferentes municípios, porém os resultados são, ainda, limitados, se pensarmos sob o ponto de vista de que Brasil tem 5.500 municípios, e que apenas um número reduzido desses foi incluído no programa de Cidades Saudáveis, em 1996 (MENDES 1998).

Para a OMS, segundo MENDES (1998), cidade saudável é aquela "em que os dirigentes municipais enfatizam a saúde de seus cidadãos dentro da ótica ampliada de qualidade de vida" (p.200).

No Brasil, é recente a preocupação com a questão, ao tomar como indicador as primeiras publicações e realizações de eventos científicos dentro dessa área temática no País, que datam da década de 1990.

No que tange à capacitação de profissionais para atuação nessa área, a Faculdade de Saúde Pública da Universidade de São Paulo criou o curso 
de especialização em promoção da saúde em 1998, sob a coordenação dos Professores Fernando Lefèvre e Maria Cecília Focesi Pelicioni. Em 1999, a Profa. Marcia Westphal organizou um curso de pequena duração sobre promoção da saúde, parte do Programa de Curso de Verão da Faculdade de Saúde Pública/USP, com a participação do representante da Organização Panamericana de Saúde, na área.

WESTPHAL (1999) e CZERESNIA (1999) consideram que a discussão sobre promoção da saúde, apesar de maior parte das ações propostas serem objeto de lei e existirem, de fato, em países "desenvolvidos", ainda é incipiente no setor saúde e na academia brasileira.

A importância da intersetorialidade é citada por WESTPHAL $e$ ZIGLIO (1999), ao mesmo tempo que levantam um problema a ser enfrentado, que é a falta de cultura política de buscar soluções integradas com os diferentes setores, para os problemas na esfera governamental e municipal. Segundo os autores, é preciso um novo modelo de políticas públicas e de investimentos em saúde com participação dos representantes dos setores da comunidade.

A apresentação resumida da história da promoção da saúde, em particular no Brasil, ao contrário de apontar os descaminhos, teve, como propósito, resgatar o movimento com vistas a propiciar uma avaliação, criar um espaço para reflexão, aprendizagem, reaprendizagem e gerar melhores condições para adequação de diferentes proposições de trabalhos à realidade brasileira, na direção da promoção da saúde.

Neste estudo, a promoção da saúde é entendida como estratégia de desenvolvimento de ações políticas, econômicas, sociais e ambientais que 
visam, em última análise, à transformação social na direção de uma melhor condição e qualidade de vida de todos os cidadãos. Nestes termos, ela é vista como um instrumento de resgate da cidadania - transformação do indivíduo em sujeito de ação e de direito.

Assim, a construção do Projeto de Saúde Ocular, a partir da perspectiva ampliada de saúde e da concepção de promoção da saúde, acima apresentada, contemplou os seguintes componentes: a educação em saúde como instrumental essencial para articular esforços de diferentes áreas (social, econômica, política); a importância de instrumentalizar os indivíduos a partir de um processo educativo para que estes possam criar mecanismos de controle de sua própria saúde (empowerment); a necessidade de desenvolver estratégias de ações intra e inter setoriais, intra e inter institucionais e interdisciplinares; a construção concreta de redes de comunicação $e$ de apoio, mediante parcerias $e$, por fim, a participação de indivíduos e grupos sociais de uma determinada comunidade, elemento de vital importância no processo. 


\section{4 - Saúde Ocular no contexto da promoção da saúde}

Entre os primeiros autores a abordarem o tema - promoção da saúde ocular - de forma a contribuir para o delineamento de ações de promoção nesta área, pode-se citar TEMPORINI (1998), educadora de saúde pública e, atualmente, professora da FSP, USP, aposentada.

A autora reafirma a interação entre promoção da saúde e educação, referindo que:

"as ações educativas constroem a base para a promoção da saúde ocular, prevenção de afecções e preservação do sistema visual, na medida em que aumentam a capacidade dos individuos na tomada de decisóes a respeito de comportamentos que influenciarão seu nível de saúde ocular".

Descreve ainda, a importância da promoção da saúde ocular para a qualidade de vida e refere que

"o individuo deve apresentar capacidade visual que the permita o desenvolvimento de potencialidades e a participação na sociedade".

Reforça a importância da participação multiprofissional $e$ multisetorial nos trabalhos de promoção da saúde, assim como da participação da população-alvo no planejamento, execução e avaliação das ações.

A OMS (1997) refere-se à promoção da saúde ocular como parte integrante da Atenção Primária dos Olhos, sendo este um componente 
vital da Atenção Primária à Saúde; em outras palavras, que a promoção da saúde deve integrar as ações de promoção da saúde ocular.

A partir das considerações até aqui expostas, cabe, agora, estar reportando à experiência profissional desta pesquisadora, em particular, à investigação, que contempla a preocupação constante com o desafio que constitui a operacionalização de ações voltadas para a promoção da saúde ocular.

A esse respeito, o que se tem a dizer é que a experiência que possui é resultado das tentativas e erros dos anos de trabalho vivenciados no serviço público de saúde, como foi referido em parágrafos anteriores.

As abordagens sobre promoção da saúde foram consideradas como um dos eixos principais para a elaboração e desenvolvimento prático do Projeto de Promoção da Saúde Ocular e Prevenção Precoce de Problemas Visuais, que foi realizado em Morungaba, de 1999 a 2000.

O caminho norteador da promoção da saúde ocular, neste Projeto, foi - processo educativo, que possibilitou a interação entre os sujeitos envolvidos $e$ a construção coletiva de um projeto na direção da constituição de cidadãos.

O trabalho direcionou seu sentido em capacitar e habilitar pessoas para que elas adquiram controle sobre suas decisões $e$ ações que beneficiem sua saúde (NUTBEAM 1998, p. 354: FREIRE e col. 1997: OPAS 1994), em particular, a saúde ocular de crianças de 0 a 7 anos.

Para isso, criou-se um espaço para que pudesse ser salientado a importância e o papel que cada ator social desempenha na vida de crianças de 0 a 7 anos. Essa convicção de que as pessoas tinham capacidade de se desenvolverem e conseguirem obter o controle sobre suas decisões na 
área de saúde ocular para elas e para as crianças, foi calcada nas premissas básicas da promoção da saúde no que diz respeito a aumentar o poder de decisão das pessoas sobre sua saúde ocular e à participação social.

Desta forma, procurou-se desencadear um processo de trabalho de modo que o escutar, o perceber e o observar as pessoas, dentro de uma perspectiva de atenção, respeito, sensibilidade e solidariedade pudessem despertar a auto-confiança, aumentando a auto-estima no interlocutor $e$, assim, criar outros laços entre o agente externo (pesquisadora) e os atores sociais

Para direcionar esforços no sentido de construir um projeto com participação social, foi necessário, antes de tudo, conhecer as pessoas - 0 que fazem, quais as suas atitudes, realidade local onde moram, os serviços em que trabalham - enfim, um pouco de sua cotidianeidade, ao lado de se deixar conhecer por elas, de forma a criar minimamente algum laço, para depois construir, em conjunto, alguma proposta de trabalho. Isso representou abrir um espaço para a aprendizagem desta pesquisadora, que procurou assumir uma nova postura em relação ao objeto de trabalho, não mais de distanciamento, de "neutralidade" do investigador, para se permitir entrar por inteiro na relação, deixando aflorar as emoções.

No caso do Projeto, por se tratar de uma área específica e ainda considerada pouco acessivel, foi elaborada uma proposta anterior, baseada no conhecimento prévio das pessoas e da realidade local, com 0 objetivo de provocar a participação dos atores sociais na direção da promoção da saúde ocular e possibilitar a construção de um projeto para a cidade. 
A atitude adotada para construção desse Projeto, na direção da promoção da saúde ocular, foi o de respeitar, escutar e ressaltar a importância dos atores sociais envolvidos: mãe, professor, pediatra, enfermeiro e pessoal de enfermagem, por entender que são pessoas que durante os primeiros sete anos de vida de uma criança, têm um contato social e físico com ela. Procurou-se, assim, valorizar os diferentes papéis sociais dentro do Projeto.

A transparência nas atitudes e o compromisso com a população, tentando demonstrar o interesse e carinho pelas pessoas e pelo trabalho, foram tomados como procedimentos metodológicos intrínsecos do Projeto.

Essa metodologia básica de trabalho, em que o respeito, a sensibilidade, a observação, o reconhecimento do outro e o aprender com a realidade permearam o estudo, abriu espaço para criar e recriar estratégias pedagógicas voltadas para o aprendizado de crianças sobre saúde ocular, envolvendo música, jogos, teatro, maquetes, cartazes e exposição.

\section{5 - Participação: principais concepções}

Na busca de definir que tipo de análise deveria ser utilizada sobre participação dos atores sociais neste estudo, fez-se necessário, antes de mais nada, reconstruir as principais concepções de participação que estiveram e ainda estão presentes, de forma predominante, em diferentes momentos históricos, mesmo que de forma sucinta. 
Recorrendo à literatura, verifica-se que uma dada concepção de participação passa a estar presente nos discursos na década de 50 , ganhando destaque na década de 80/90, em particular na área da saúde, assumindo diferentes conotações.

De maneira geral, as propostas que contemplam a participação da população, planejadas pelo Estado, têm como alvo principal os grupos sociais excluídos, como parte de programas de desenvolvimento, e com finalidade explícita de reduzir as desigualdades e promover a justiça Social. (SANTOS 1998).

Nos anos 50, a participação comunitária, fomentada por projetos sociais voltados para micro-realidades, trazia uma concepção de participação instrumental, em que a população alvo era encarada como simples receptora de ações previamente definidas, que objetivavam alcançar o mínimo de desenvolvimento das condições de saúde e promover a capacidade de auto-ajuda dentre os indivíduos e as famílias. (SANTOS 1998)

$\mathrm{Na}$ década de 60 , a percepção de direitos começa a movimentar a população em busca de melhores condições de vida. Diante disso, a estratégia que o Estado adotou foi o planejamento na área social, em busca da diminuição das lacunas do sistema, dentro da lógica da racionalidade econômica.

Assim é que, em 1965, a Organização Pan-Americana de Saúde (OPS) já definia participação como "o processo mediante o qual os indivíduos se transformam de acordo com suas próprias necessidades e da sua comunidade, adquirindo um sentido de responsabilidade com seu próprio bem estar e o da coletividade, assim como a capacidade de contribuir 
consciente e construtivamente com o processo de desenvolvimento..." (OPS 1965, cit. Santos 1988). Desta forma, a participação se caracterizou como um instrumento para atingir as metas planejadas.

$\mathrm{Na}$ década de 70, a participação apareceu, de forma oficial, no documento da Conferência Internacional de Saúde, em 1978, organizada pela Organização Mundial da Saúde, em Alma/Ata (URSS), que a apresenta como um instrumento viabilizador da universalização dos serviços de saúde. A participação da comunidade deveria se dar nas três etapas da implantação dos cuidados primários de saúde: na avaliação da situação, na definição do problema e na fixação de prioridades.

A participação passou a ser institucionalizada pelo Estado a partir dos anos 80, como necessidade de manter o controle de movimentos populares que passam a apresentar a noção de direitos sociais, atribuindoIhe (à participação) um papel mais real e mais compromissado: os individuos-cidadãos passam a assumir uma posição de controle em relação ao Estado. Assim sendo, a participação deixa de ser meramente instrumental, para criar canais de decisão, em que o homem-sujeito faz parte de um processo e não apenas atua como receptor de ações e decisões superiores (SANTOS 1998).

A partir deste breve histórico, torna-se importante verificar as atuais abordagens de participação, segundo classificações adotadas por diferentes autores.

Do ponto de vista etimológico, de origem do latim (participare), participar significa fazer parte de tomar parte em, fazer saber. informar, anunciar (CUNHA 1997, p.584). 
Para ROBIROSA, CARDARELLI e LAPALMA (1990), participar significa tomar parte de algo com outro, repartir ou entrar ativamente na distribuição. Devido à complexidade da participação, ela deve ser analisada com relação à quantidade de atores sociais que participam, níveis, campos possíveis e graus da mesma.

Para eles, existem três aspectos que devem integrar a definição de participação:

- Formar parte: no sentido de pertencer, ser integrante.

- Ter parte: no desempenho das ações adaptativas.

- Tomar parte: influir a partir da ação.

Assinalam, ainda, a importância de diferenciar a ação individual da coletiva, sendo que esta última, por implicar a presença simultânea de pessoas, significa considerar comportamentos que se influenciam mutuamente; em função disso, a participação deve contar com um componente de organização e se orientar por decisões coletivas. A ação coletiva supõe dois elementos: um conjunto de regras que determina a participação no processo de decisão e uma regra para agregar as decisões individuais que concorram para a formação da vontade coletiva.

Para esses autores, existem três níveis de participação, desde a mais restrita a mais ampla:

- Informação: deve ser a necessária em qualidade e quantidade devendo a população ter condições para avaliar a informação que maneja.

- Opinião: corresponde a um nível mais complexo de participação, em que os participantes podem emitir opiniões sobre assuntos, supõe 
um nível mais amplo que a informativa; a opinião pode modificar decisões e ações.

- Tomada de decisões: os participantes podem decidir sobre seus próprios assuntos o que supõe uma adequada $e$ oportuna informação, o reconhecimento de acordos, diferenças, mecanismos adequados de discussão e de tomada de decisões (para tomada de decisões é necessário o seguinte percurso: reconhecimento do problema, ter informações disponiveis, alternativas de interpretação, intercambio ou confrontação de informação, tomada de decisão, planejamento da execução, execução, avaliação dos resultados, processos e consequiências).

Com esses elementos, os autores diferenciam a participação real, baseada na influência social e na tomada de decisões daquela participação simbólica, em que se exerce um grau mínimo de influência.

Assinalam, ainda, que a participação não é automática ou espontânea, sendo necessário um aprendizado, quer dizer, ações que incrementariam as capacidades dos participantes para análise da realidade $e$ influência sobre outros. Segundo esses autores, quando se substitui a passividade pela participação, cria-se um espaço para ampliar os conhecimentos $e$ aperfeiçoar a competência dos atores sociais participantes do processo. Além disso, chamam atenção para as situações políticas e sociais de ordem geral, que tanto podem ser facilitadoras quanto obstáculos de sua viabilidade e condicionantes dos distintos níveis, graus e formas de participação. Enfim, ressaltam a complexidade do tema que envolve, desde aspectos relacionados a atitudes, valores e crenças dos atores envolvidos, aspectos grupais vinculados à interação, liderança, até 
influências sociais, econômicas e políticas gerais, que potencializam ou dificultam a participação.

Ao se buscarem outras referências e estudos sobre participação, chegou-se a uma publicação da OPS sobre Desenvolvimento $e$ Fortalecimento dos Sistemas Locais de Saúde (OPS 1995), que apresenta uma revisão sobre o tema em foco, em suas mais diversas acepções: participação comunitária, envolvimento na comunidade, participação social, participação dos consumidores, apoderamento (empowerment). participação popular, intervenção na comunidade para o desenvolvimento da saúde, destacando que a concepção mais utilizada no presente momento é a de participação social.

Do ponto de vista teórico, a participação social pode ser entendida, segundo a Organização Panamericana de Saúde, como "um processo social democrático, de construção e reconstrução da realidade, contínuo $e$ permanente, realizado por um conjunto social que compartilha vivencias $e$ pautas culturais que as identificam, promovem comportamentos comuns para fazer frente aos eixos e sucessos..."(OPS 1995, p 12).

Nessa concepção, conjunto social é descrito como sendo os atores sociais, que vivem em uma determinada área geográfica, em diferentes grupos, organizações, instituições e setores.

As ações de participação social incluem, também, as ações de participação comunitária, mas estes termos não devem ser confundidos, pois a participação social é um conceito mais amplo, que engloba a comunitária. A participação comunitária, tal como ela comumente é entendida, refere-se às atividades individuais, familiares para promover a saúde, prevenir e tratar doenças e participar dos processos de 
recuperação dos doentes, mas geralmente relacionadas com a saúde, traduzida por uma participação consciente em que as ações são intencionais para satisfazer e resolver as necessidades percebidas (OPS/HSP 1990, p.10; OPS/HSP 1995, p. 12).

Na participação social, os atores sociais de uma determinada área geográfica, representados pelas diferentes instâncias sociais (organizações, grupos, setores) formam uma aliança na busca de identificarem dificuldades de saúde ou outras afins, para planejarem e colocarem em prática as soluções decididas dentro do próprio conjunto social, (OPS 1995).

Em outras palavras, corresponde a "processos sociais através dos quais os grupos, as organizações, as instituições, os setores - incluindo todos os atores sociais de uma dada região geográfica - intervêm na identificação das questões de saúde ou outros problemas afins e se unem em uma aliança para desenharem, aprovarem e colocarem em prática as soluções. A participação social é por natureza sistêmica, referindo-se d interação de muitos atores dentro do sistema social" (OPS/HSP 1990, p. 10).

Em suma, o processo de participação social tem como objetivo tornar as pessoas sujeitos históricos que construam seu próprio futuro a partir da definição de prioridades, busca de opções e a tomada de decisão (OPS/HSP 1995, p. 13).

Ainda conforme a OPS, a participação social pode tornar-se relevante e adquirir dimensões importantes à medida que se desenvolve no nivel local, pois implica, dentre outras coisas, desenvolver habilidades 
de decidir em conjunto, que exige entender as relações de poder que se estabelecem entre os diferentes setores, instituições e indivíduos.

É importante, em se tratando de participação social, que fiquem evidentes as relações de poder que se estabelecem entre o Estado e a sociedade civil, entre as instituições e a população e entre os prestadores e os usuários de serviços, para promover a participação e de desenvolver a capacidade de tomar decisões no interior dos conjuntos sociais.

A participação social pode ocorrer de diferentes formas, conforme assinaladas abaixo:

- Colaboração:

Neste caso, os usuários das organizações setoriais são voluntários e não existe preocupação dos conjuntos sociais na condução ou gerência do processo.

- Co-gestão:

A participação é entendida como co-gestão, quando existem as intervenções nas decisões. Na prática, este tipo de participação esbarra em barreiras, como o modelo hegemônico da prática médica, que não abre espaço para questionamentos em relação à doença. Portanto, para que os conjuntos sociais sejam co-gestores, de fato, é necessário que os atores sociais pertencentes a este conjunto tenham acesso a decisões.

- Autogestão:

Constitui uma forma de participação mais independente da vontade institucional; pode surgir também em consequiência de reivindicações dos próprios conjuntos sociais, como expressão de sua autodeterminação. 
- Negociação:

É um tipo de participação que está assentada na idéia de que o Estado $e$ as instituições setoriais são responsáveis pela prestação de serviços eficientes e com qualidade, assim, a participação se concentra no controle por parte dos usuários dessas ações. Neste sentido, requer que as organizações dos conjuntos sociais tenham consciência dos seus direitos e disposição para lutar pela sua defesa quando são afetados.

A participação pode ter diferentes abordagens, dependendo da disciplina e do campo de estudo no qual está situada (OPS/OMS 1995). Como exemplo, na área do comportamento organizacional, a participação se refere a um tipo particular de liderança.

Já no campo da educação, Scrinivasan (1990), citado por OPS/OMS (1995) diferenciou quatro conceitos:

- Compartilhar custos: neste caso todos os participantes devem investir algum recurso no projeto coletivo.

- Mão-de-obra voluntária: supõe a existência de esperança em que os membros da comunidade gastem um tempo seu e se esforcem na construção de um bem comum para a comunidade.

- Obrigação contratual: é baseado em um documento, tipo de contrato ou convênio, no qual se especificam as responsabilidades de cada parte, instituição e comunidade.

- Tomada de decisóes: o elemento central deste conceito é a participação da comunidade; para esta atuação, é necessário criar mecanismos de auto-capacitação para que os atores sociais possam participar dos processos de análise dos problemas e necessidades, bem como formulação de propostas. 
No campo da saúde, em relação à atenção primária a saúde, Rifkin (1981) descreve quatro diferentes enfoques para participação:

- Conceito de saúde pública: o público é envolvido para ajudar a controlar e a erradicar doenças infecto-contagiosas e por sua vez - pessoal da saúde determina quais as ações e tomada de decisão que devem adotar.

- Conceito de planejamento em saúde: a participação da população é promovida com o objetivo de proporcionar recursos para um determinado projeto, como: mão-de-obra, tempo, materiais, recursos. Neste caso, comumente são convocados os líderes comunitários, mas aos assuntos de real interesse para a comunidade, nem sempre é dada a importância devida.

- Conceito de participação no desenvolvimento comunitário: implica em mobilizar pessoas e planejar o desenvolvimento, em nível local, envolvendo a população na tomada de decisões naquilo que afeta sua saúde. A todo momento se ressalta a importância da análise da situação e das relações de poder e tem, como foco, a transformação da realidade social.

- Conceito da auto-ajuda: parte da premissa que existe a falta de capacidade e eficiência do Estado para resolução dos problemas de saúde da população; em função disso, são promovidos trabalhos coletivos de ajuda mútua. O cuidado com a saúde faz parte da vida de todos. Manter-se saudável é responsabilidade individual e não apenas do médico - este é o pressuposto da auto-ajuda (RIFKIN 1981; In: OPS/OMS 1995). 
Ao identificar e adotar o enfoque estratégico para trabalhar a participação, em uma determinada localidade é de fundamental importância que a administração local identifique os atores sociais que participam de todo o processo de gestão.

O estudo propiciado pela OPS integra na questão da participação outros conceitos essenciais, quais sejam, de intersetorialidade e de promoção da saúde, como pode-se observar nos parágrafos abaixo.

Assim, um fator relevante e que adquire importância no nivel local, no sentido de fortalecimento dos atores sociais é a abordagem intersetorial, por favorecer a criação de diferentes espaços, que permitem a participação social na tomada de decisões, estratégias, planejamento e programas em diferentes setores, com a intermediação dos atores sociais, que buscam e criam articulações e momentos de reflexão, objetivando a totalidade do processo social (OPS/HSP 1995).

Um dos maiores obstáculos para o desenvolvimento da intersetorialidade são os modelos nacionais que privilegiam, historicamente, 0 eixo econômico e também uma visão centralizadora dos problemas e das suas soluções, não considerando a diversidade de cultura da população $e$ possibilidade de soluções mais eficientes e eficazes na medida em que os atores sociais têm um contato mais refinado e um maior conhecimento da suas realidade e necessidades (OPS/HSP 1995).

$O$ desenvolvimento intersetorial pode significar um canal de financiamento para as ações de saúde, na medida em que mostra $e$ inclui componentes da saúde nas mudanças e atividades dos outros setores, para trazer benefícios para os atores sociais (OPS/HSP 1995). Para isso, é necessária a formulação de políticas gerais e específicas de apoio, de 
forma que sejam assumidas por todos os participantes do processo, tendo que ocorrer uma coerência dos objetivos nos diversos setores para buscarem um objetivo maior, que é o bem estar e melhores condições de vida.

$\mathrm{Na}$ busca de melhores condições de saúde individual e coletiva, na perspectiva da promoção da saúde o individuo deve atuar coletivamente, no sentido de atacar os problemas de saúde e para isso, devem-se criar e recriar as atividades do setor em todos os niveis, principalmente no âmbito local (OPS/HSP 1995).

A abordagem da promoção da saúde é importante na discussão sobre participação, pois a promoção busca gerar condições necessárias para que os conjuntos sociais e indivíduos adquiram poder suficiente para influir $e$ controlar hábitos e estilos de vida que determinam sua saúde. Dentro desse processo de aumentar o poder dos atores sociais, surge um espaço para o desenvolvimento da consciência dos problemas e suas origens, a partir da multiplicação de informações e da formação de redes de comunicação que permitem criar condições para que os conjuntos sociais $e$ indivíduos tomem consciência $e$ adotem atitudes que os conduzam a melhores condições de saúde e qualidade de vida. É o exercício da plena cidadania (OPS/HSP 1995: WHO 1986; NUTBEAM 1999, p. 354).

Para DEMO (1988) "participação é conquista, significando um processo no sentido legítimo do termo: infindável, em constante vir-a-ser, sempre se fazendo" ( $p .18)$

Esse mesmo autor refere que participação não pode ser entendida como uma concessão pois é, em essência, autopromoção e existe enquanto conquista social. Enquanto tal, cita ainda a importância que a participação 
ocupa no espaço das grandes conquistas e que para isso é necessário compromisso, envolvimento e presença em ações, às vezes arriscadas. Neste sentido, o planejamento participativo deve partir de interesses da comunidade levando-se em conta sua contribuição e potencialidade.

0 autor refere ainda que, havendo um processo intenso de participação podem-se reduzir as desigualdades pela possibilidade de defesa de interesses comuns contra interesses adversos; como tal processo fundamenta a dimensão básica da cidadania (não só deveres mas também direitos) conquista-se a liberdade; todavia, alerta, em situação de extrema desigualdade, dificilmente se fugirá dos embates no processo de participação.

O mesmo autor acredita que a educação é um instrumento fundamental da participação política enquanto formação para cidadania.

A participação é vista por ele como instrumento para o controle do poder, bem como a consolidação de uma cultura democrática.

Uma outra abordagem de participação é a apresentada por BORDENAVE (1994) que a define como "caminho natural para o homem exprimir sua tendência inata de realizar, fazer coisas, afirmar-se a si mesmo e dominar a natureza e o mundo. Além disso, sua prática envolve a satisfação de outras necessidades como interação com os demais homens, a auto-expressão, o desenvolvimento do pensamento reflexivo, o prazer de criar e recriar coisas, e ainda a valorização de si mesmo pelos outros" (p. 16).

Para esse autor, a participação está assentada em duas bases: a afetiva e a instrumental; a primeira está relacionada com o sentir prazer de fazer as coisas com outras pessoas e a segunda, com o fato de que 
fazer as coisas com outras pessoas é mais eficaz e eficiente do que fazer sozinho. Para ele, o fazer parte, tomar parte e ter parte é uma forma de classificar a participação sendo que "a prova de fogo não é o quanto se toma parte, mas como se toma parte". O autor distingue a participação micro da macro. Para ele, a "micro participação é uma associação de duas ou mais pessoas numa atividade comum na qual elas não pretendem unicamente tirar benefícios pessoais ou imediatos". Com relação à macro participação, esta "compreende a intervenção das pessoas nos processos dinâmicos que constituem ou modificam a sociedade" (BORDENAVE 1984, p.17).

As diferentes maneiras de participação são também descritas por BORDENAVE (1994):

- espontânea: é aquela que leva os homens a formarem diversos grupos - de vizinhos, amigos de futebol, etc:

- imposta: é aquela no qual o indivíduo é obrigado a fazer parte do grupo e realizar algumas tarefas:

- voluntária: os participantes criam os próprios grupos e definem e estabelecem sua organização seus objetivos e métodos de trabalho:

- provocada: agentes externos provocam e ajudam os outros a realizarem seus objetivos ou os manipulam a fim de atingir seus próprios objetivos:

- concedida: compõe o poder ou recebe a influência dos subordinados.

O mesmo autor descreve a respeito dos graus e os níveis de participação: em relação aos graus, o objetivo é verificar como se dá o 
controle que os membros de um determinado grupo exercem em relação às decisões.

Quando a população alcança níveis de participação mais elevados, chegando à participação decisória, reduz-se a distância entre os que planejam e os que executam; às vezes, para alcançar niveis mais altos é necessária a capacitação e experiência e também árduas lutas pois, muitas vezes, a participação dos membros é controlada por alguns, com o objetivo de não deixar seus interesses se perderem, limitando drasticamente a participação daqueles, principalmente quando se trata do Estado, como uma das partes interessadas (BORDENAVE 1994).

Segundo o autor, em uma sociedade de classes, como a nossa, tornase difícil uma participação homogênea, pois os interesses são diversos e conflitantes, uma vez que os indivíduos estão localizados em posições diferentes do ponto de vista das relações sociais. Assim sendo, a participação dos membros não se dá da mesma maneira, envolvendo desde funções de agentes expressivos (artistas, filósofos, comunicadores) até instrumentais (técnicos e profissionais).

Para ele, a participação é mais eficiente quando se utilizam ferramentas operativas como:

- o conhecimento da realidade, suas percepções, valores, temores e aspirações, realizando com isto diversos objetivos ao mesmo tempo: produzir saber, conscientizar, solucionar problema, capacitar e formar, na prática, para a participação:

- a organização, mediante distribuição das tarefas e coordenação dos esforços individuais; 
- a comunicação, no sentido de aprenderem a utilizar os diferentes meios de comunicação e métodos de discussão e debate, que sejam democráticos:

- a educação como meio de se aprender a participar e aperfeiçoá-la através da prática e reflexão. A qualidade da participação pode aumentar quando as pessoas aprendem a conhecer a sua realidade: a refletir; a superar contradições; a identificar premissas; a antecipar consequiências; a entender novos significados e a distinguir efeitos de causas.

Para se exercer a participação, há que existir um processo de aprendizagem por meio da prática e teoria, não se pode transmitir um conteúdo mas, sim, uma mentalidade e comportamento coerente a partir de uma vivência coletiva através da prática, desenvolvendo, assim, a consciência crítica e de aquisição de poder (BORDENAVE 1994).

Remontando a base teórica sobre participação e na busca de novos caminhos para a sua conceituação, teve-se acesso a um estudo científico, com cuja autora esta pesquisadora se identificou, referente a um trabalho que arriscou transitar pela pesquisa-ação, desenvolvendo relacionamentos que passaram a fazer parte do processo metodológico, próximo à metodologia adotada neste estudo, como pode ser visto mais adiante.

Trata-se de um artigo de Rosinha Borges Dias (1998), relato agradável da questão da participação em uma experiência de controle da doença de Chagas, em Cansanção, cidade do interior de Minas Gerais. 


\section{Para essa autora, participação}

"passa pela descoberta de que somos parte de um todo maior que a nossa pessoa, família ou comunidade; parte deste mundão de Deus, dessa imensa vida que circula nos seres da natureza e por todo 0 universo. Eque por isso mesmo devemos fazer a nossa parte para que esse mundo seja mais humano e livre do que é." (p. 2).

A autora chama atenção para a necessidade de reconhecer a inserção social do indivíduo, ao se falar de participação, isto é, reconhecê-lo na articulação entre o mundo e o microcosmo e os diversos aspectos que compõem o seu existir.

Dias ressalta, ainda, que a participação deve ter como pano de fundo, por parte do pesquisador, a escuta (como atenção concentrada) e respeito à cultura local. A partir da escuta pode-se despertar nas pessoas seus potenciais, a auto-estima e salientar a importância de cada ator social dentro do processo de construção de qualquer projeto, abrindo-se um espaço para que eles reconheçam sua própria realidade e busquem novas alternativas de vida, (DIAS 1998).

Usando suas palavras,

"o processo de participação consiste em fazer com que 0 povo comece a se reunir e se encontrar, para descobrir e discutir os seus problemas de vida e para encontrar uma solução.." (p. 12).

A sintonia com essa forma de abordagem foi tamanha, a ponto de identificar os momentos vivenciados em Morungaba, local deste estudo, com os de Cansanção, do estudo de DIAS (1988), claro que, em outra dimensão. 
Durante a realização deste estudo, que teve como objetivo analisar a participação dos atores sociais na construção do Projeto de Promoção de Saúde Ocular e Prevenção de problemas visuais, foram desencadeados momentos reflexivos no interior de diferentes grupos da comunidade de Morungaba, a partir de questões básicas de saúde ocular. $O$ objetivo que se buscava era que os envolvidos no processo se direcionassem para um trabalho de participação comunitária, no primeiro momento, com a intenção de trabalhar com vistas à promoção da saúde ocular e prevenção de problemas visuais, a partir de ações individuais, familiares e da comunidade.

No decorrer do estudo, foi deflagrado um processo de participação, inicialmente no sentido instrumental, referido anteriormente, que caminhou gradualmente e não da mesma maneira para todos, na direção da participação social, percorrendo as fases metodológicas de construção de um projeto social (SANTOS 1994), buscando-se o fortalecimento das pessoas envolvidas, mediante a facilitação de interação entre elas, a instrumentalização das mesmas em relação ao tema, em busca de algo que beneficiaria a população de crianças de 0 a 7 anos do Município.

Desta forma, a análise da participação, neste estudo, contemplou o estudo do envolvimento dos diferentes atores sociais no processo de desenvolvimento do projeto de saúde ocular, com enfoque na promoção da saúde.

Esse envolvimento foi interpretado a partir da observação da participação no treinamento teórico-prático, na multiplicação das ações, no movimento de atores sociais em busca dos direitos. 
Para este trabalho adotou-se o conceito de participação no sentido mais amplo da acepção: ter, fazer e tomar parte de alguma ação/atividade, programa ou projeto social. Isto significa que o indivíduo ou grupo social entra no processo com suas experiências, seus valores, seus conhecimentos, seus sentimentos e emoções. É também apropriar-se de algo, ou seja, tomar para si, no sentido de transformar e de ser transformado, nas relações com outros membros, parceiros, indivíduos.

Para tanto, uma das manifestações concretas é a tomada de iniciativa do sujeito e a capacidade de criar e recriar e, não apenas reproduzir. Um outro aspecto importante é o de tomar consciência.

É necessário ressaltar que o cenário de qualquer Projeto social é constituido de atores sociais. Chamamos de atores sociais todos os individuos que de alguma forma, são mobilizados para determinada ação. O desempenho destes atores sociais, de modo geral, pode-se dar de forma semelhante e, ao mesmo tempo, diferente. É preciso admitir que os indivíduos não atuam da mesma maneira, à medida que não podem ser considerados homogêneos, pelo contrário, eles atuam de forma distinta, pois a existência, a formação, o seu pensar, também se dão de forma diferente.

Diante desse quadro, faz-se necessário repensar o lugar da saúde ocular e as possibilidades de estar direcionando as ações específicas na perspectiva da promoção da saúde e prevenção de problemas visuais. Para isso é importante ter clareza da situação em que se encontra a área em questão, o que na leitura desta autora, exige um longo percurso, já que nem sequer se apresenta como uma área consolidada de fato, do ponto de vista da saúde pública, como espaço interdisciplinar, interprofissional e 
voltado para a preocupação com a saúde coletiva. Muito pelo contrário, a saúde ocular, no Brasil, ainda está solidamente arraigada ao modelo médico, fragmentado, de atendimento individual e voltado à correção, em detrimento da prevenção de problemas e promoção da saúde.

A organização dessa área privilegia determinadas parcelas da sociedade, com poder de compra, sem levar em consideração grande parte da população, que permanece sem acesso a esse tipo de atenção e sem conhecimento das possibilidades de estar assegurando a sua saúde ocular e estar desenvolvendo a capacidade de poder discernir o que é melhor para si.

Essa situação foi considerada para a elaboração do projeto.

Algumas características preliminares que nortearam a implementação, a implantação e a execução do Projeto são aqui apresentadas.

Para o desenvolvimento inicial do Projeto, chegou ao Município de Morungaba um agente externo, com objetivo acadêmico-institucional que elaborou e apresentou para as lideranças políticas locais uma proposta de Projeto (Anexo 6), na área de Saúde Ocular para crianças de 0 a 7 anos de idade, a ser ai desenvolvido. Tratou-se, inicialmente, de uma participação provocada, no sentido colocado por BORDENAVE (1994), qual seja,

"... [A] participação provocada é aquela em que agentes externos ajudam outros a realizarem seus objetivos ou os manipulam a fim de atingir seus próprios objetivos... " (p.28). 
Esse agente externo colocou-se como coordenador do Projeto e ao mesmo tempo, como sujeito-pesquisador.

Reconhece-se que em toda participação provocada existe a possibilidade de intenções manipuladoras. Assim sendo, procurou-se ficar atento durante todo o processo para que isso não ocorresse.

Diante do exposto, esta proposta tinha, como objetivo final, desencadear um processo de participação transformadora, a partir da provocada, em que os cidadãos locais tomassem para sí o controle social do seu desenvolvimento.

Inicialmente, justifica-se a participação provocada pelo agente externo (o pesquisador), mediante o reconhecimento da atuação hegemônica na área de saúde ocular, segundo o paradigma médicobiológico, centrada na assistência médica - clínica, individual -, voltada ao nivel curativo, em detrimento da prevenção de problemas visuais e da promoção da saúde.

Neste sentido, o Projeto proposto está calcado na perspectiva da promoção da saúde e, a partir dessa perspectiva, a estratégia consistiu em o agente externo definir alguns passos para a construção do projeto local, com os atores sociais de diferentes setores do Município em questão. A aparição do agente externo teve o caráter intencional de provocar, por meio de um instrumento pré-elaborado, atores sociais para - desenvolvimento de uma determinada forma de atuação em saúde coletiva, na perspectiva de sua transformação.

Em decorrência disso, esta investigação caracteriza-se por buscar uma prática transformadora dos atores sociais envolvidos. 
A intencionalidade de respeitar o ritmo dos atores sociais parte do pressuposto de que nem todas as pessoas participam da mesma forma para a obtenção de algum objetivo comum. Assim sendo, fica implícita a postura do agente externo em respeitar o ritmo e as características institucionais e da comunidade: a Prefeitura, a direção (das Diretorias) da Educação, da Saúde, do Esporte e Lazer, famílias, e outras que surgiram durante o seu processo.

Outra característica marcante desta pesquisa, como já dito em momentos anteriores, foi a de desenvolver o processo de construção do Projeto no contexto da promoção da saúde, requerendo-se para isso a participação, a parceria e a intersetorialidade, buscando cada vez mais o controle social por parte dos atores sociais (empoderamentol fortalecimento).

Para tanto, buscou-se a construção de parcerias entre os distintos setores $e$ instituições existentes no Município, com a intenção de concretizar um trabalho intersetorial $e$ interinstitucional, envolvendo: Saúde, Educação, Esporte e Lazer, empresas e organizações nãogovernamentais para garantir a consecução dos objetivos delineados.

É nesse espaço delimitado que esta Pesquisa - Construção de um Projeto de Saúde Ocular para Crianças - propõe-se transitar, isto é, no caminho da promoção da saúde, e dentro dela, da promoção da saúde ocular.

Para isso, utilizou-se, além da experiência teórico-prática acumulada, referente ao tema da promoção da saúde, a história profissional da autora na área de saúde pública, na condição de ortoptista sanitarista. 


\section{OBJETIVO}

Analisar o processo de participação vivenciada por atores sociais ${ }^{2}$ na construção de um projeto de promoção da saúde ocular e prevenção precoce de problemas visuais para crianças de 0 a 7 anos de idade, no Município de Morungaba, SP.

2 Serão considerados atores sociais os participantes na programação e execução do Projeto em questão. 


\section{PROCESSO METODOLÓGICO DA PESQUISA}

\section{1 - Abordagem sobre o método}

O estudo definiu como linha, para o desenvolvimento desta pesquisa, a Pesquisa-Intervenção ou Pesquisa-ação.

A intenção inicial era a de deflagrar um processo participativo de investigação-ação junto a atores sociais, moradores de uma dada localidade, envolvendo-os em todas as etapas de construção coletiva de um projeto de saúde ocular, enquanto sujeitos de um processo a ter continuidade no tempo, independente da presença do pesquisador.

Entretanto, ao se considerarem as especificidades da área de saúde ocular, no Brasil, até agora, pouco acessível à população em geral, tanto no que diz respeito ao conhecimento básico, quanto no que se refere à assistência em serviços de saúde - com o agravante de quase inexistência de conceitos básicos e práticas em saúde ocular entre trabalhadores de saúde -, tornou-se inviável para fins do presente projeto, levar adiante uma proposta pura de pesquisa-ação.

Mesmo assim, a autora acreditou ser possivel e criou e desenvolveu uma proposta intermediária, capaz de, a partir de uma fase de socialização do saber acerca da área em questão, estar deflagrando um processo que, aparentemente de participação instrumental ${ }^{3}$, caminhasse

\footnotetext{
${ }^{3}$ Entende-se por participação instrumental, aquela em que serve como meio para atingir mais eficientemente os objetivos de um projeto previamente elaborado (RIZZINI e cols 1999; $p$. 40).
} 
para a construção de novas possibilidades, alternativas na linha da pesquisa-ação, durante o seu desenvolvimento.

O propósito principal do Projeto foi desenvolver um olhar mais sensivel das pessoas envolvidas no trabalho, para as questões da saúde ocular, sobretudo das crianças, e criar condições para que os atores sociais se apropriassem de um determinado conhecimento científico, abrindo um espaço para que eles sentissem autonomia, a ponto de determinar como deveriam planejar o trabalho para os próximos anos.

A intenção da autora foi, portanto, caminhar na direção da " pesquisa social com base empírica, que é concebida e realizada em estreita associação com uma ação ou com a resolução de um problema coletivo e no qual os pesquisadores e os participantes representativos da situação ou do problema estão envolvidos do modo cooperativo ou participativo"(GIL 1999, p.46).

Nesta pesquisa, o método foi considerado um processo, porque ele se movimenta, "ele não se esgota em si mesmo, é dinâmico, ele pode ser relacionado com o modo científico, com a prática, aos objetivos, ao objeto do estudo e a ação profissional" (SANTOS 1993, p.46).

Neste sentido, o método adotado por este estudo foi um conjunto de procedimentos inter-relacionados, passíveis de adaptações, transformações e recriações, de acordo com a leitura dos atores locais e do próprio pesquisador, dentro do espaço criado para a investigação científica e experimentos profissionais, como instrumento de orientação prática.

Desta forma, criou-se um espaço de intercâmbio de conhecimentos entre atores sociais e pesquisadora sobre a realidade em que se 
desenvolveu o projeto social, neste caso, na área de saúde ocular, desencadeando-se o desenvolvimento da programação, execução e revisão ou avaliação do processo de trabalho.

É importante relembrar qual deveria ser o espaço da pesquisadora no desenvolvimento de um projeto social, antes de especificar as fases metodológicas da pesquisa.

A pesquisadora deveria contribuir no processo de trabalho como um ator social, aproximando-se do grupo a ser trabalhado mas, preservando a sua identidade. (RIZZINI e col. 1999).

Além disso, deveria reunir ganhos, no decorrer da pesquisa, tanto de conhecimento quanto de ação, juntamente com a população envolvida no trabalho.

Para a pesquisadora, ficou nítido o impulso que a movimentou a pensar no tema da pesquisa e o que foi buscar na população em estudo: o processo de construção, execução e de avaliação de um projeto de intervenção, na perspectiva da promoção da saúde ocular e prevenção precoce de problemas visuais.

Partiu-se do reconhecimento de que a pesquisadora deveria estar aberta a aprender, a trocar experiências e a ensinar sem se sobrepor (FREIRE 1999).

Neste momento, faz-se necessário esclarecer como foi entendida e - que representou a palavra projeto para a autora deste estudo.

A pesquisadora buscou definições mais abrangentes, coerentes com a perspectiva do estudo proposto, qual seja, desenvolver o processo de construção de um Projeto e buscar uma prática transformadora de atores sociais envolvidos, mediante um processo metodológico que 
possibilitasse ir construindo, alterando/modificando e/ ou transformando o mesmo, a partir da ação/reflexão coletiva.

Para tanto, tomaram-se, como referência, as colocações de MACHADO (2000), o qual, de forma lúcida, apresenta o sentido que se procurou dar ao termo projeto neste trabalho. Segundo esse autor, embora a palavra projeto costume estar associada, tanto ao trabalho do arquiteto ou do engenheiro, quanto a trabalhos acadêmicos, às etapas iniciais na estruturação de planos de ação, em diferentes áreas, tacitamente, no entanto, a idéia de projeto está presente em contextos muito mais abrangentes, muito menos técnicos, muito mais pessoais, dizendo respeito a praticamente todas as ações características do modo de ser do ser humano. Assim, em sentido humano, a própria vida pode ser identificada como um contínuo pretender ser, uma tensão em busca de uma pretensão, na feliz expressão de MARÍAS (1966), por ele citado.

Nesse modo de entender, projetam todos os que estão vivos, todos os que antecipam cursos de ação, os que concebem transformações de situações existentes em outras imaginadas e preferidas, elegendo metas a serem perseguidas, tanto em termos pessoais, quanto em termos coletivos, o que situa a idéia de projeto no terreno próprio do exercício da cidadania.

Prosseguindo, o autor chama atenção para o fato de a escolha das metas sempre se dar em um cenário de valores socialmente acordados, daí a associação imediata entre as idéias de projeto e de valor, tornando esse conceito especialmente relevante, envolvendo tanto os trabalhos com projetos, em sentido metodológico, quanto o projeto 
pedagógico/social, em sentido amplo, passando, naturalmente, pelos projetos pessoais daqueles que dele participam (p.1-2).

Desta forma, nessa perspectiva abrangente, a idéia de projeto inclui, tanto a dimensão metodológica, quanto a biológica, a psicológica, ou política, sem separá-la do outro que a complementa, qual seja, a idéia de valor. Em outras palavras, "os projetos que alimentamos - $e$ que nos sustêm - antecipam transformações em busca de uma realidade que prefiguramos e que queremos construir; os valores representam aquilo que queremos conservar conosco, o que queremos levar na viagem rumo ao novo..."(MACHADO 2000, p. VII)

Apesar de toda a abrangência, a idéia de projeto, segundo o autor, apresenta algumas características gerais, alguns ingredientes fundamentais, sem o que não se pode ter senão uma pálida idéia de seu significado: a referência ao futuro, a abertura para o novo e o caráter indelegável da ação projetada.

A referência ao futuro, em forma de um esboço, desenho, guia da imaginação ou semente da ação, significa a antecipação de uma ação, distinguindo-se de uma previsão, de uma simples visão prospectiva, ou de uma conjectura, muitas vezes, representações antecipadoras, mas entendida como um futuro que está sendo gestado, de uma realidade que está sendo construída. Nas palavras de BARBIER (1998:52), citado por MACHADO (2000), "O projeto não é uma simples representação do futuro, do amanhã, do possivel, de uma idéia; é o futuro a fazer, um amanhã a concretizar, um possível a transformar em real, uma idéia a transformar em acto". (p. 6) 
A abertura para o novo, contrariamente à concepção de um futuro totalmente determinado (que elimina completamente a idéia de projeto), é entendida com o sentido de certa abertura para o desconhecido, para o não-determinado, para o universo de possibilidades, da imaginação, da criação, para o risco do insucesso: "Não se faz projeto, quando só se tem certezas, ou quando se está imobilizado por dúvidas"(p.7).

O caráter indelegável da ação projetada, como um dos ingredientes fundamentais do projeto, quer dizer: uma ação a ser realizada pelo sujeito que projeta, individual ou coletivamente. Em outras palavras: "não se pode ter projetos pelos outros"(p.7), da mesma forma que não se pode viver pelo outro.

Em resumo, um projeto sempre conteria a idéia de antecipação de uma ação em busca de uma meta, em um futuro não determinado, cuja realização depende efetivamente dos agentes; daí poder dizer que a capacidade de projetar constitui o traço mais característico da atividade humana: "O modo de ser do ser humano éo permanente pretender ser" $(\mathrm{p}$. 8).

Por tudo que foi abordado nos parágrafos anteriores e pelos objetivos propostos por esta pesquisa, a autora considerou pertinente adotar o enfoque de projeto para o processo desenvolvido, pois as metas e os meios foram sendo transformadas de acordo com os desejos, sonhos e necessidades de seus participantes.

Por outro lado, a idéia de projeto, do ponto de vista técnico, e que usualmente é empregada na área da Saúde, como um documento que antecede à execução e que prevê metas concretas a serem realizadas, também está presente neste estudo, em sua fase inicial, quando a 
pesquisadora apresentou a proposta a atores sociais do município de Morungaba para viabilizar o desenvolvimento do Projeto, entendido na forma ampla, anteriormente apresentada. Em outras palavras, o processo foi considerado Projeto, à medida que se trata de uma construção em processo, que não se encerrou com a elaboração desta tese, mas que continua, com a apropriação do mesmo pelos atores locais, com condições de se ampliar, incorporar novos elementos, fortalecer-se como um novo modo de trabalhar as questões que afetam os cidadãos do Município. enfim, um Projeto de e para os seus moradores. 


\section{2 - Delimitação do quadro de referência teórico}

\subsection{1 - Eixos norteadores do estudo}

Como trabalhar na prática, na condição de pesquisador e de ator social, com médicos, pessoal de enfermagem, professores, mães e crianças no sentido de movimentar a sensibilização, o desejo, o querer saber, o compartilhar e o fazer?

Na tentativa de encontrar algumas respostas para essa pergunta, buscou-se apoio em alguns modelos estabelecidos de promoção da saúde e prevenção de problemas de saúde, para aplicá-los na área de saúde ocular. Para isto, tomaram-se, como base teórica e marco referencial, princípios metodológicos propostos por: NUTBEAM (1998), GREEN (1992), NAIDOO e WILLS (1996), assim como procedimentos técnicos de projeto social de SANTOS (1993) e RIZZINI e col. (1999).

Entretanto, é importante ressaltar que não foi utilizado um modelo pronto, acabado, previamente elaborado, para aplicar na prática deste Projeto; ao contrário, partiu-se da premissa que, para se atuar na linha de um projeto social e na perspectiva da promoção da saúde, deveriam ser consideradas as opiniões dos atores sociais, mudanças políticas, mudanças do meio ambiente e econômicas, e todos os fatores que o envolvessem, direta ou indiretamente.

Assim, foram utilizados, como apoio teórico e metodológico, as seguintes abordagens e propostas de modelos de desenvolvimento de 
projetos sociais e de promoção da saúde, para elaboração e execução deste Projeto social na área de saúde ocular:

- Método Profissional de SANTOS (1993), como um meio de conhecimento e interpretação desta realidade e, ao mesmo tempo, um instrumento de sua transformação (p.47).

Para a construção deste projeto, utilizou-se a concepção de processo metodológico em movimento, especificando os seguintes momentos: aproximação, investigação significativa, interpretação diagnóstica, re-aproximação, programação, execução do projeto, revisão e sistematização.

A instrumentação do processo contou com a contribuição de vários autores, com seus conceitos, perspectivas e instrumentos técnicos. De forma sucinta, são apresentados os enfoques dados no presente estudo:

Educacional: Com o objetivo de socializar os conhecimentos básicos de saúde ocular - teóricos e práticos - com os atores sociais, foi utilizada nesta pesquisa, a linha educacional proposta por Paulo Freire, em seu livro Pedagogia da Autonomia (1999), no que se refere aos saberes necessários para a prática educativa com o educando.

O autor faz uma abordagem técnico científica, de forma criativa e de fácil entendimento, sobre alguns caminhos para a prática educativa transformadora: o respeito, o comprometimento, o saber escutar e a humildade durante o processo educativo (FREIRE 1999, p. 33-141)

Apresenta uma proposta pedagógica que tem, como perspectiva, a ética, o respeito à dignidade e a autonomia do educando. 
"Ensinar não é transferir conhecimentos... ...Formar é muito mais do que puramente treinar o educando no desenpentio de destrezas."

Essa abordagem contribuiu para a capacitação de profissionais, no que se refere à socialização de conhecimentos entre atores sociais, habilitando-os de forma que pudessem escolher o comportamento $e$ atitude que considerassem mais adequados para a situação, desenvolvendo para isto, atividades envolvendo três aspectos: cognitivo (informação e conhecimento), afetivo (atitudes e sentimentos) e habilidades.

- "Empowerment" (fortalecimento): essa abordagem contribuiu para direcionar o processo educativo na medida em que se trabalhou com os atores sociais para que eles identificassem seus próprios interesses e problemas, e desenvolvessem a habilidade e confiança para atuarem de alguma forma sobre eles (NAIDOO e WILLS 1996: DECLARAÇÃO DE JACARTA 1997: NUTBEAM 1998). No projeto, foram consideradas as habilidades de comunicação, planejamento e organização dos diferentes atores sociais e do próprio pesquisador.

- Médica/preventiva: esta abordagem implica uma concepção do processo saúde enfocada mais sobre a doença, centrulizando-se no aspecto clínico, biológico do corpo humano. Neste sentido, considerou-se prevenção em saúde toda ação antecipada, com base 
no conhecimento da história natural da doença referida por LEAVEL e CLARK (1976), especialmente no que se refere à prevenção secundária. ROUQUAYROL (1993) destaca que a prevenção é abrangente, inclui, também, a ação dos profissionais em saúde e tem início em nível das estruturas políticas e econômicas. Para esta pesquisa, apoiou-se nesta concepção mais abrangente, uma vez que as ações/atividades de saúde ocular desenvolvidas durante o processo de trabalho contemplou os vários setores, as diversas áreas do conhecimento que possibilitaram caminhar na direção da prevenção da saúde. Esta abordagem está presente no Projeto, uma vez que um dos impactos que se espera, ao longo do tempo, é a redução da morbidade, mediante atividades que poderão vir a serem desenvolvidas com grupos ou faixas etárias específicas, tal como o desenvolvimento da triagem visual em crianças, adotado com essa intenção.

- Modelo da Ação Intersetorial proposto por NUTBEAM (1998): no que se referiu ao pensamento de que não existem modelos ou teorias que definam o processo de ação intersetorial, mas o que se têm, são tentativas de revisão das experiências de ação intersetorial e o relato de atividades de conexão e construção, considerando o passado recente, com o objetivo de entender 0 processo pelo qual as organizações, ou parte delas, trabalham juntas. Isto inclui: o entendimento do contexto, (as razões de por quê as organizações têm que trabalhar juntas); uma avaliação da infraestrutura, (se a organização tem capacidade de ocupar-se com 
um planejamento de ação) $e$ um planejamento para chegar à ação $e$ sustentabilidade, (o plano de ação, que traz os benefícios para todos os envolvidos, as regras e as relações claras, necessitará de uma ação).

- Algumas propostas de operacionalização do modelo "PRECEDE" de GREEN (1992), citado na introdução deste documento. A contribuição foi na distribuição das ações em diferentes fases de um cronograma, que inclui desde o levantamento de interesses e problemas de saúde ao diagnóstico administrativo com ações educativas formuladas no interior de um processo de planejamento.

Ao elencar as diferentes abordagens e instrumentos técnicos para suporte deste estudo, identificando aspectos em que cada uma delas poderia trazer a sua contribuição, partiu-se da idéia de que este trabalho não se propunha a aprofundar-se em teorias $e$, sim, utilizar pontos importantes de diferentes abordagens, tentando integrá-los e adaptá-los a uma determinada realidade.

Durante todo o percurso, constantemente a autora se viu voltando a se perguntar:

- Como lidar com as dificuldades advindas de uma formação pessoal e/ou profissional, nem sempre voltada para a realidade social?

- Como trabalhar a promoção da saúde, dentro de uma área em que não se priorizam os aspectos básicos da saúde ocular para a formação pessoal e coletiva dos indivíduos? 
- Como ajudar outros atores sociais a descobrirem a importância da saúde ocular para o contexto da qualidade de vida?

- Como fazer para trabalhar as próprias dificuldades da pesquisadora/ator social?

Sabia, ao mesmo tempo que se indagava, que não existe uma fórmula pronta ou um manual contendo as respostas e que teria que enfrentar o desafio de buscar construí-las a partir de uma prática coletiva, contando com o saber e a vivência da pesquisadora, os saberes e vivências de outros atores sociais e conhecimento acumulado disponivel.

4.2.2. Estratégias de um Projeto de Promoção da Saúde Ocular e Prevenção Precoce de Problemas Visuais

Para a elaboração Projeto, consideraram-se as diretrizes estratégicas da WHO (1997) sobre cuidados básicos com a saúde ocular e pontos básicos e estratégicos, descritos em trabalhos científicos de autores tomados como apoio teórico, anteriormente citados, e na Declaração de Jacarta (In: MINISTÉRIO DA SAÚDE 1997), como um dos eixos norteadores do Projeto, como segue:

- planejamento do processo de trabalho junto com os representantes locais, a partir de um diagnóstico básico:

- participação da comunidade no processo de trabalho:

- realização de parcerias com diferentes setores da sociedade;

- intersetorialização entre saúde - educação - comunidade; 
- capacitação dos atores sociais. Entende-se por capacitação os meios proporcionados para se chegar à competência (RIZZINI e col 1999).

Assim, considerando este Projeto como um processo, norteado por um conjunto de procedimentos interrelacionados, dividiu-se o trabalho em momentos vivenciados durante o desenvolvimento do mesmo, seguindo proposta de SANTOS (1993):

$1^{\circ}$ Momento-aproximação, investigação e conhecimento da realidade local, programação e elaboração do Projeto

Esse momento consistiu em criar as condições necessárias para a elaboração e viabilização do Projeto, no sentido de o município estar assumindo o mesmo, dele se apropriando enquanto parte da política pública local.

$2^{\circ}$ Momento-intersetorialidade e formação de parcerias:

Após a aceitação do Projeto de Promoção da Saúde Ocular, foram articuladas parcerias locais com o setor da Saúde, Educação, Comunidade e Empresas, por intemédio e junto com o Conselho Municipal de Saúde, com a intenção de envolvê-los no trabalho, tentando garantir o comprometimento dos atores sociais na realização do mesmo.

Em relação à realização de parcerias com empresas locais, esta foi prevista e efetivada, a fim de envolver outros setores da sociedade, no que diz respeito a doações de armações de óculos e lentes a serem 
fornecidas para crianças que delas necessitassem, e que não apresentassem condições de comprá-las.

$3^{\circ}$ Momento - aproximação, divulgação e execução do Projeto de Saúde Ocular:

A aproximação de atores sociais foi provocada, novamente, para ampliar o contato, na tentativa de discutir estratégias de execução do Projeto.

A divulgação do trabalho foi feita entre mães, pessoal da saúde, escolares, professores e comunidade como um todo, com o objetivo de criar o envolvimento de diferentes setores da sociedade, convidando-os a criarem uma parceria para que o Projeto se efetivasse.

A aplicação de um instrumento de avaliação - questionários - deu-se nessa etapa do trabalho. Foram aplicados com autoridades locais, professores, educadores de creches, pessoal da saúde e em uma amostra de mães de crianças da população alvo, assim que teve início a execução das ações propostas.

A execução do Projeto de Promoção da Saúde Ocular e Prevenção Precoce de Problemas Visuais ocorreu, de acordo com a disponibilidade dos envolvidos na realização do mesmo, respeitando-se a seqüência:

- Sensibilização de atores sociais para as questões da saúde ocular:

- Aplicação de questionários junto a mães, pessoal da saúde e professores:

- Orientação e habilitação dos atores sociais envolvidos no Projeto:

- Desenvolvimento da parte prática, com acompanhamento e supervisão: 
- Triagem e retestagem das crianças por professores, pessoal da saúde e mães:

- Encaminhamento para o of talmologista;

- Encaminhamento de crianças que apresentaram problemas oculares à escola e ao serviço de saúde, para recebimento de óculos e/ou atendimento de maior complexidade:

- Informatização dos dados contidos nos questionários.

Triagem Visual: o seu lugar estratégico na prevenção e deteç̧ão precoce de problemas visuais

A triagem visual integrou este estudo como uma ação proposta a ser desenvolvida com crianças de 0 a 7 anos por diferentes atores sociais, inserindo-se como abordagem Preventiva e de Deteç̧ão precoce de problemas visuais, uma vez que, conforme referência anterior, um dos impactos que se esperaria, ao longo do tempo, na faixa etária do estudo, diz respeito à redução da morbidade, a partir de atividades desenvolvidas ou por desenvolver com crianças de grupos ou faixas etárias específicas.

Em relação ao processo de trabalho dos professores que a realizaram, vale assinalar que foram recriados diferentes caminhos pedagógicos, sugeridos e construídos pelo grupo de trabalho, para desenvolver o conhecimento sobre os olhos, sua função e cuidados com crianças menores de 7 anos de idade. Após a fase do trabalho pedagógico em salas de aula, as crianças foram triadas por professores e educadores de creche. Essa triagem compreendeu testes que possibilitaram: verificar a musculatura extrínseca ocular (movimentos oculares e sinais de 
presença, ou não, de estrabismo): avaliar as condições do aspecto externo ocular no que diz respeito à presença de sinais e sintomas de problemas visuais; e medir a acuidade visual, mediante a aplicação de três métodos adotados, de acordo com a idade da criança.

A seleção desses testes foi realizada pela pesquisadora, dada a especificidade da matéria, que requer o conhecimento especializado, como foi relatado na parte referente à aproximação do tema.

Após o treinamento teórico-prático, submeteu-se à discussão dos professores, a viabilização da realização dos testes, tendo-os como aplicadores, segundo sua disponibilidade. A decisão do grupo, após sugestões levantadas, foi no sentido de que cada professor faria um subprojeto, de acordo com a realidade e disponibilidade da escola $e$ creche, quer se tratasse de escolas municipais, estaduais ou privadas.

Em relação ao pessoal da Saúde, mães e pessoal da Pastoral da Criança, a decisão sobre triagem visual se deu da mesma forma, respeitando-se a disponibilidade e o nivel de participação individual ou de grupo.

Desta forma, definiu-se que a triagem visual compreenderia:

- Avaliação do aspecto externo:

- Cover test, para observar a presença de estrabismo:

- Aplicação dos testes de acuidade visual de acordo com a faixa etária (LIN-FUN 1971: SPERANDIO 1999b).

0 a 3 anos - teste de reação à oclusão (LIN-FUN 1971; IZECKSON 1972; (RAWFORD 1982).

3 a 5 anos - teste da mãozinha (jogger hand test - anexo 12)(LINFUN 1971) 
Maior que 5 anos - teste de Snellen (LIN-FUN 1971).

Esses testes foram escolhidos pelo fato de serem de fácil execução e entendimento por parte do aplicador e crianças, com boa aceitação por parte das crianças, além de seu baixo custo.

O teste de reação à oclusão é um teste grosseiro, dado que não permite quantificar a acuidade visual, apenas qualificar de forma subjetiva; apesar disso, é utilizado para identificar importantes diferenças de visão de um olho para outro, em menores de 3 anos, quando não se dispõe de recursos mais sofisticados. É um teste que não deixa de fora da triagem visual as crianças menores de 3 anos.

Sperandio, em 1990, detectou em um trabalho de triagem visual, realizado com crianças de 0 a 8 anos, em uma creche municipal de São Paulo, $40 \%$ de falsos negativos para a faixa etária de 0 a 2 anos, no que dizia respeito à triagem de estrabismo, utilizando, como subsídio, o teste de reação à oclusão, (SPERANDIO 1990).

Não obstante as limitações do referido teste, a sua utilização com crianças menores de 3 anos torna-se relevante para a área de saúde ocular, por possibilitar que diferentes atores sociais comecem a prestar atenção na parte visual das crianças, como integrante do controle de saúde, desde a mais tenra idade.

Em relação aos testes de angular mãozinha e de Snellen, os mesmos foram utilizados no presente estudo, por permitirem mensurar o quanto uma criança/pessoa enxerga. No mesmo estudo, referido no parágrafo anterior, Sperandio encontrou $2,94 \%$ de falsos negativos, no trabalho desenvolvido com professoras e pajens da creche, para uma população de 235 crianças de 0 a 8 anos (SPERANDIO 1990). 
Em um outro estudo, também realizado por Sperandio, em 1999, com educadoras da creche da Faculdade de Saúde Pública da Universidade de São Paulo, que trabalhavam com crianças de 3 a 7 anos, os testes de angular mãozinha e Snellen, precedidos de triagem de sinais e sintomas visuais, utilizados pelas educadoras na triagem visual, apresentaram uma sensibilidade de $75 \%$ e $93,6 \%$ de especificidade (SPERANDIO $1999^{4}$ ).

$O$ ato de reeducar os atores sociais, principalmente aqueles que atuam na área da saúde e educação, para observarem o desenvolvimento e funcionamento do aparelho visual de crianças, $e$ orientarem pais $e$ crianças quanto aos cuidados necessários e ao seu direito de contar com a assistência compativel, amplia as possibilidades de um trabalho de prevenção $e$ de identificação precoce e tratamento oportuno de problemas visuais.

Com o objetivo de padronizar procedimentos, foram criados instrumentos básicos de apoio para pesquisa para os diferentes participantes, que consistiram em dois manuais sobre "Promoção da Saúde Ocular e Detecção Precoce de Problemas Visuais", um para mães e pessoal da pastoral, apresentado de forma mais simples, e outro, direcionado para o pessoal da saúde e educação (anexos 4 e 5 ).

4 Documento interno do Departamento de Saúde Materno-Infantil, da FSP-USP Relatório de Estágio realizado na Creche da FSP-Usp, em 1999, como parte do Programa de Pós-Graduação - nível Doutorado. 
$4^{\circ}$ Momento - sistematização e divulgação de resultados:

Nesta fase, foram realizadas a revisão e a sistematização dos dados obtidos na área delimitada para a pesquisa, para análise e divulgação dos resultados, e que constituiram o material desta tese.

Entretanto, vale lembrar que a intenção do Projeto, desde seu início, foi deflagrar um processo que fosse assumido pelos atores locais e que perdurasse no tempo, na perspectiva de se consolidar na gestão atual da Prefeitura municipal $e$, posteriormente, ampliar, incorporando outras questões relevantes para o município, na direção do exercício da participação, da cidadania, no contexto da promoção da saúde. Desta forma, continua em processo o Projeto, cabendo um parêntesis apenas para a elaboração e apresentação do que constituiu esta tese.

A elaboração e execução de um Projeto social - delineado segundo premissas básicas da promoção da saúde, com enfoque na área de saúde ocular -, podem ser melhor visualizadas na representação gráfica abaixo, que procurou retratar os movimentos/a dinâmica das relações dos atores sociais, no processo de desenvolvimento do mesmo, em seus diferentes momentos: 
Fig. 1 - Modelo de Planejamento de Intervenção Adaptadgi

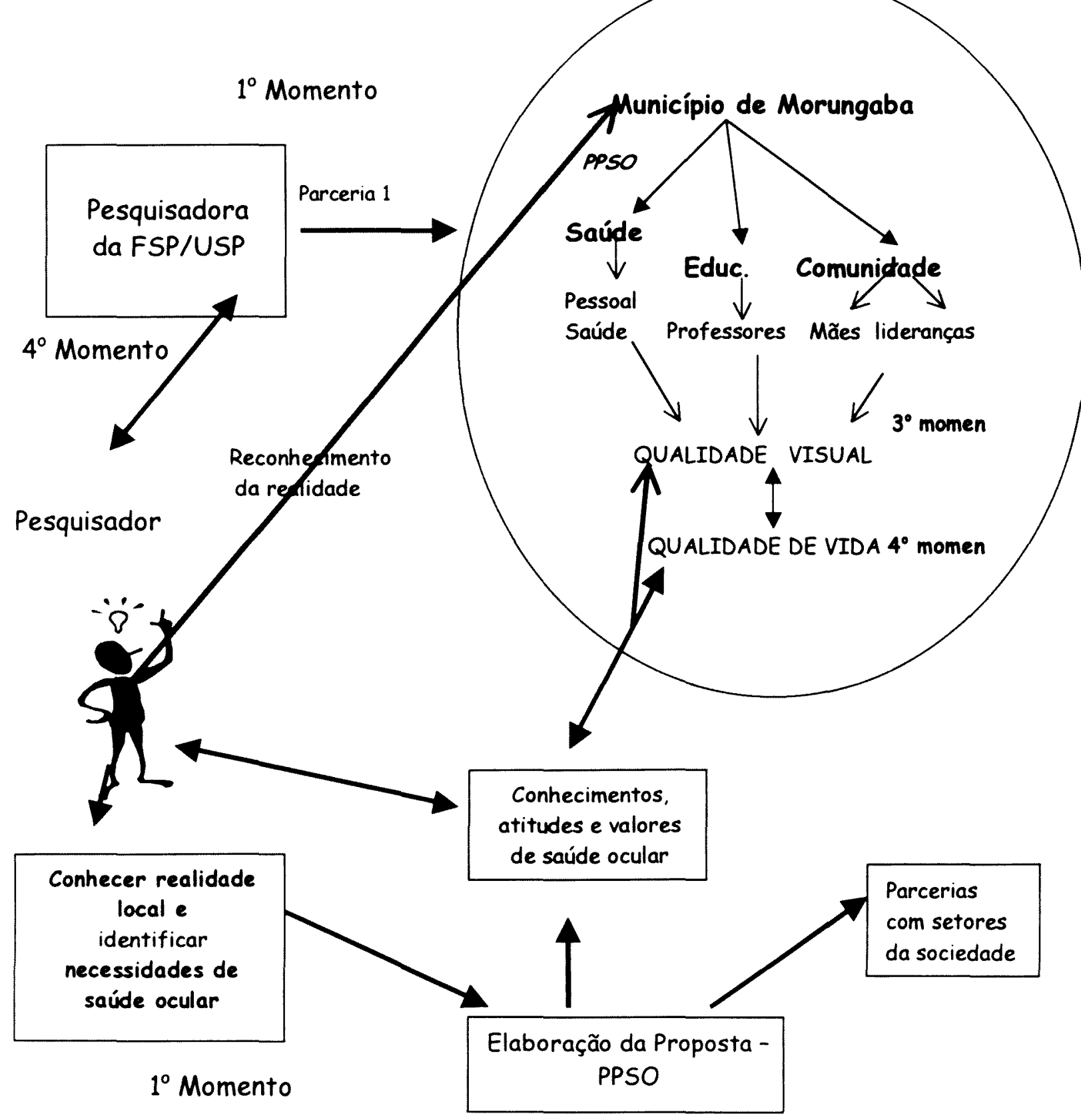

Organização da habilitação da

Comunidade e nos diferentes setores

Educação em Saúde

Obs.: PPSO - Projeto de Promoção da Saúde Ocular e Prevenção de Problemas Visuais. 


\section{3 - Cenário do estudo}

Às vezes, quando o céu está muito azul, lembra-se de Morungaba... Uma pequena cidade do interior de São Paulo, próxima ao município de Itatiba, distando $40 \mathrm{~km}$ de Campinas, aproximadamente. Guarda na sua arquitetura traços do século XIX, quando foi fundada (1888).

Morungaba... Este nome veio dos índios, que chamavam as abelhas produtoras de mel de morunga ou Morungaba, que, na língua do índio tupi, significava colméia.

Cidade que surgiu ao redor do ribeirão dos Mansos e do rio Jaguari, tendo como primeiro bairro o dos Mansos. Sofreu a influência forte dos imigrantes, principalmente dos italianos, que vinham para trabalhar na lavoura; esses imigrantes estabeleceram-se na região e logo deixaram a agricultura e passaram ao desenvolvimento do comércio, enquanto alguns passaram a proprietários de chácaras e sítios.

Os imigrantes italianos moldaram o lado rústico dos moradores do bairro dos Mansos e influenciaram em todos os aspectos: na forma de morar, de vestir, nos métodos da agricultura, na forma da organização social, na língua, na religião e nos costumes.

Depois de muitas curvas, de subidas e descidas, em uma estrada arborizada, deve-se prestar atenção ao tentar encontrar a cidade, pois, ela pode passar como um "relâmpago". Quando se está dentro dela, tudo é muito lindo, é um perfeito cenário, lembrando os nossos desenhos escolares, composto de ruas arborizadas, mais adiante a Biblioteca Municipal, a Praça onde está a Igreja, o Coreto, o supermercado, o Centro de Saúde, um pequeno comércio e o Banco. A mesma estrada liga Itatiba 
ao circuito das águas (Amparo, Serra Negra, Lindóia, Águas de Lindóia), corta o Município, separando-o em duas áreas: a localizada mais na região central e a região localizada mais perifericamente, onde se situam os Bairros São Benedito e Brumado; a população residente nessa área é considerada carente pelas autoridades locais.

Morungaba faz limite, ao norte, com Amparo, a leste, com Bragança Paulista, ao sul, com Itatiba, a oeste, com Campinas, a noroeste, com Pedreira e, a nordeste, com Tuiutí. No extremo sudeste, o rio Atibaia separa Morungaba de Itatiba, e a Serra das Cabras faz a divisa com Campinas (Fig. 2).

E as pessoas... quão simpáticas elas são... calmas, caminham como se estivessem sem preocupação, observando, admirando ou até mesmo preocupadas mas, sem manifestarem.

A Praça da Igreja serve de ponto de encontro de idosos e de jovens que ficam a papear, contrastando o velho com o novo. $O$ cavalo e a moto moderna, a escola de computação e o bazar, armazém e o restaurante "self service"... Todos os eventos da cidade concentram-se na Praça.

Ah! Morungaba, lugar dos doces deliciosos, de tudo quanto é sabor, coco, mamão, uva e do café com sabor de mel. Cidade de poetas e pintores, da caminhada pelas montanhas, das fazendas, sítios e estradas sem fim.

A Cidade está mudando. Na década de 90, algumas indústrias instalaram-se no Município, trazendo crescimento e a Prefeitura investiu em obras públicas para melhoria da sua infra-estrutura, ampliando suas perpectivas. 


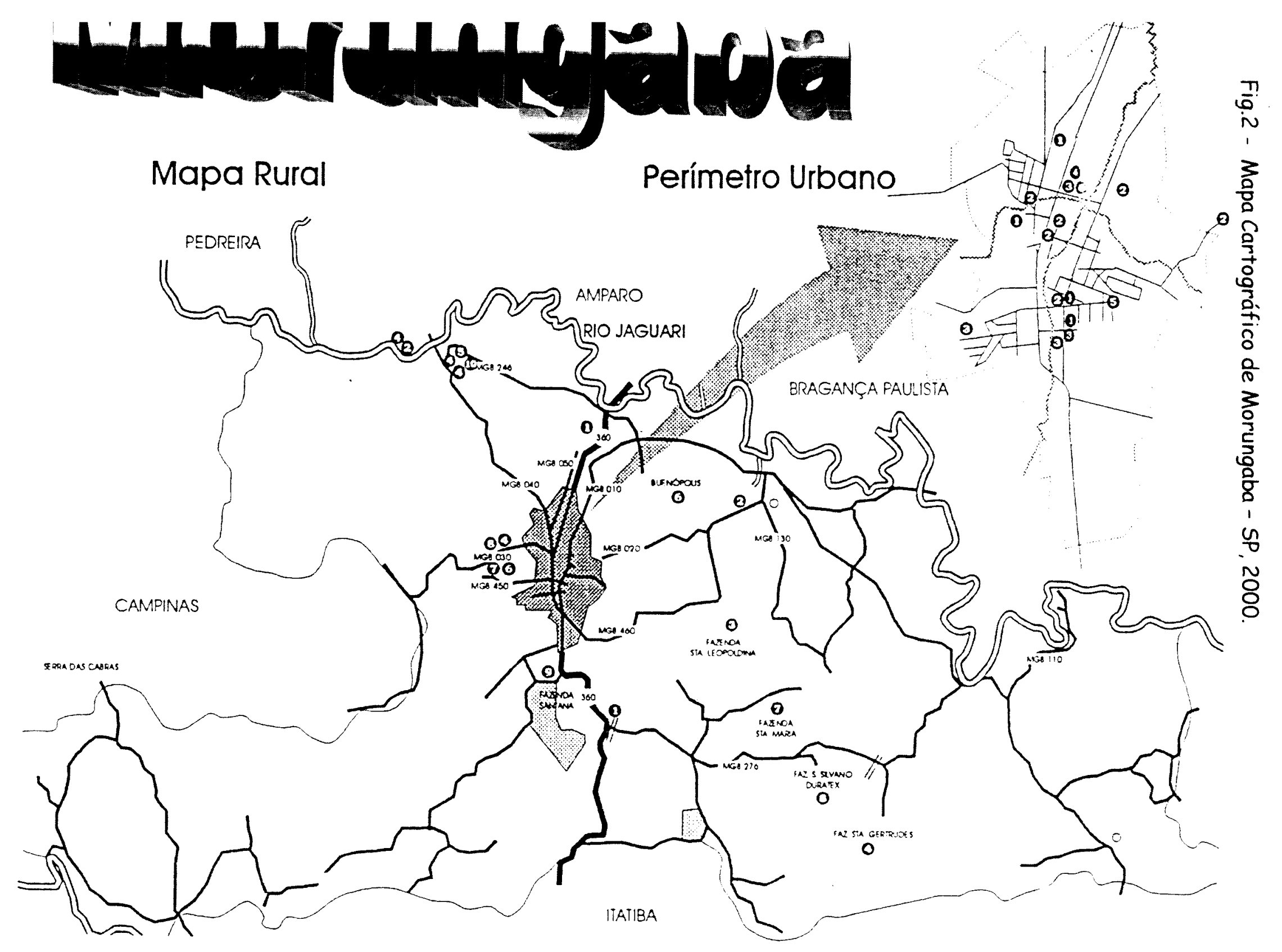


Morungaba passou a integrar as cidades - estâncias, mudando, inclusive, seu nome em 1994, para Estância Climática de Morungaba (Foto 1 e Foto 2).

Para que se tenha uma idéia mais clara do Município, são apresentados nos parágrafos seguintes, alguns dados estatísticos sobre sua população, o seu desenvolvimento econômico e sobre os setores de saúde e educação.

\section{População:}

- Projeto de Saúde Ocular se desenvolveu no Município de Morungaba devido às especificidades do serviço de saúde e de educação e à população, constituída de cerca de 10.000 habitantes, à época do início do estudo.

Em 1990, a população, segundo o último censo, era de 8.012 habitantes; em 2000, segundo dados preliminares do Censo de 2000 do Instituto Brasileiro de Geografia e Estatística (IBGE), a população era de 9.919 habitantes, distribuída entre 4.914 mulheres e 5.004 homens. (IBGE 2001)

A distribuição geográfica era de 7.840 habitantes na área urbana e 2.409 na rural, apresentando uma Taxa de Urbanização de 76,50\%.

A população de 0 a 7 anos que este estudo abrangeu foi estimada, a partir dos dados preliminares do Censo de 2000, em 1.400 crianças.

Em Morungaba não existem favelas, mas algumas construções precárias na área rural, próximas às olarias. 
Foto 1 - Município de Morungaba Estância Climática

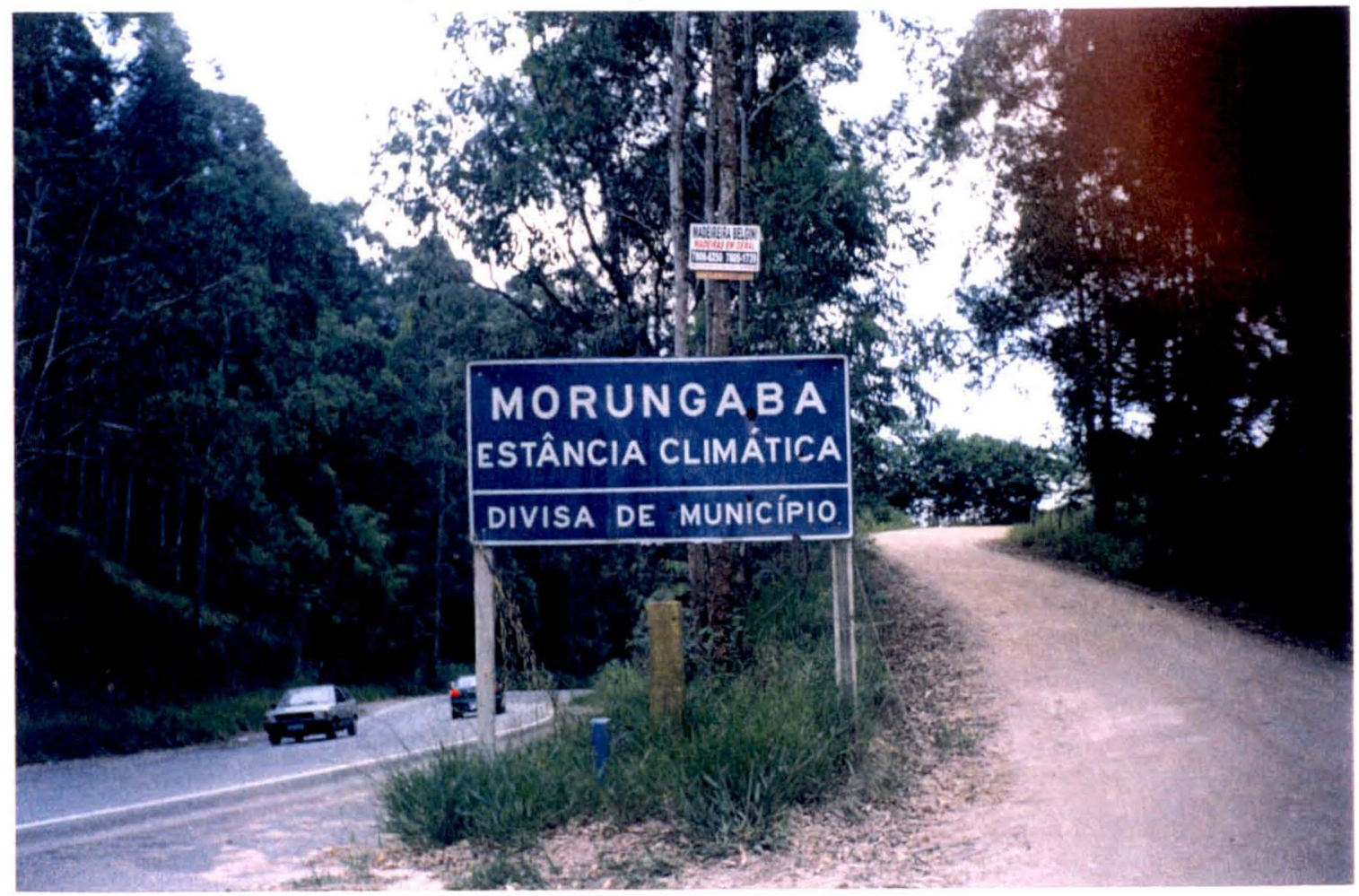

Foto 2 - Vista panorâmica da Cidade de Morungaba - SP, 2000.

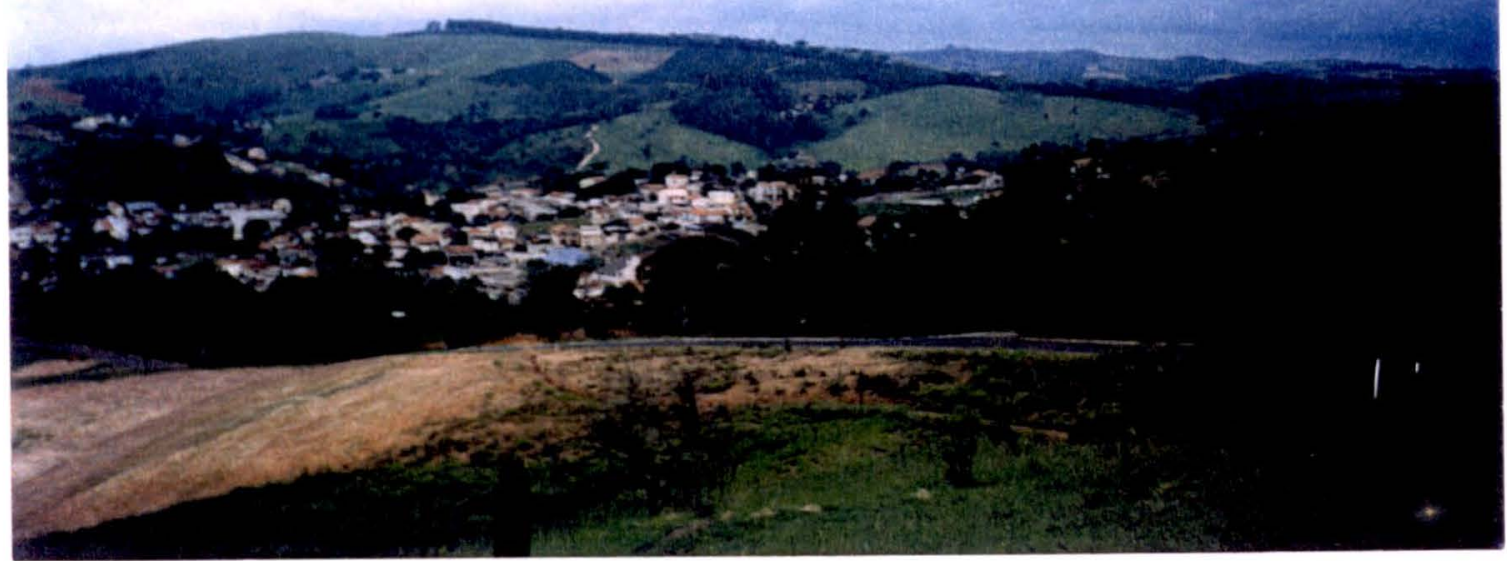


No ano 2000,100\% das residências na área urbana estavam ligadas à rede de abastecimento de água; a água é captada do Ribeirão dos Mansos, que corta o Município. As residências ligadas à rede de esgoto atingiam quase $96 \%$.

A coleta de lixo cobre $100 \%$ da população residente na área urbana e na área de expansão (loteamentos mais afastados da região urbana); não existe coleta na área rural. ${ }^{5}$

\section{Desenvolvimento Econômico:}

O comércio manteve o curso da história dos demais municípios: iniciou com os armazéns, dando lugar, mais tarde, para as lojas, mas manteve as fortes características do interior: atualmente, conta com aproximadamente 130 estabelecimentos comerciais.

Morungaba conta com cerca de 9 fábricas e 15 olarias. As fábricas são:

- Fiação Alpina (fios);

- Valclub (lingerie);

- Maliber (tecelagem);

- Sorel (óculos):

- David (doces);

- Cury e Cury (tempero);

- Tonasa (tempero);

- Monaliza (bolsas).

\footnotetext{
${ }^{5}$ Os dados foram fornecidos por funcionário da SABESP, em telefonema de 22/2/00
} 
A agricultura contribui fortemente na economia local, com culturas de café, arroz, milho, uva, feijão, fumo, e outras... Outra atividade encontrada no Município é a de produção de tijolos em olarias, nas quais se percebe que os empregados são pessoas de baixo poder aquisitivo e que acabam por residir próximo a elas, em moradias precárias.

\section{Saúde:}

No setor saúde, Morungaba conta com 1 Centro de Especialidades, 1 Centro de Saúde, no qual funciona o programa de saúde mental, 1 Posto de Saúde na zona rural, inaugurado no mês de outubro de 2000 e um Hospital Geral que atende ao Sistema Único de Saúde e setor privado.

Pacientes que requerem serviços de saúde de maior complexidade tecnológica são encaminhados para os municípios vizinhos: Itatiba, Campinas e Jundiaí.

Em janeiro de 2000, o Município não contava com Secretário de Saúde, e sim com um Diretor de Saúde, médico responsável pelas questões gerenciais dos serviços de saúde local, juntamente com a coordenadora de saúde local, auxiliar de saúde.

A vigilância epidemiológica do Município está sob a responsabilidade de um dentista.

A cidade conta com 5 dentistas que desenvolvem o programa de saúde bucal nas unidades de saúde e nas escolas municipais.

No Município, trabalham 10 médicos na assistência, sendo distribuídos em 2 unidades de saúde, de acordo com as seguintes especialidades descritas no Quadro 2: 
Quadro 2. Distribuição de médicos segundo especialidade. Morungaba, 1999

\begin{tabular}{|l|c|}
\hline $\begin{array}{c}\text { Especialidades } \\
\text { Médicas }\end{array}$ & $\mathbf{N}^{\circ}$ \\
\hline Clínica Geral & 3 \\
\hline Pediatria & 2 \\
\hline Ginecologia & 2 \\
\hline Oftalmologia & 1 \\
\hline Psiquiatria & 1 \\
\hline Otorrinolaringologia & 1 \\
\hline TOTAL & 10 \\
\hline
\end{tabular}

Um Clínico Geral trabalha todos os dias, meio período: os demais médicos são contratados para trabalharem 2 ou 3 dias, por semana.

O Quadro 3 apresenta o número de profissionais não médicos, de nível universitário, na área da saúde:

Quadro 3. Distribuição do número de profissionais segundo formação. Morungaba, 1999

\begin{tabular}{|l|c|}
\hline Profissionais universitários & $\mathrm{N}^{\circ}$ \\
\hline Enfermeira & 1 \\
\hline Fonoaudióloga & 1 \\
\hline Psicólogo & 2 \\
\hline Assistente Social & 2 \\
\hline TOTAL & 5 \\
\hline
\end{tabular}


No Quadro 4, estão descritos os profissionais técnicos e pessoal auxiliar da área da saúde

Quadro 4: Distribuição de Técnicos e pessoal auxiliar

\begin{tabular}{|l|c|}
\hline \multicolumn{1}{|c|}{ Técnicos e Auxiliares } & $\mathbf{N}^{\circ}$ \\
\hline Auxiliar de enfermagem & 6 \\
\hline Técnico de enfermagem & 2 \\
\hline Atendente de Enfermagem & 2 \\
\hline Aux. Administrativo & 5 \\
\hline TOTAL & 15 \\
\hline
\end{tabular}

O Hospital ${ }^{6}$ é conveniado com o Sistema Único de Saúde (SUS), disponibilizando 50 leitos para o setor público.

Para se ter uma idéia do quadro de saúde do Município, são apresentados alguns dados da Fundação SEADE e do DATASUS, de 1998/1999:

- Nascidos vivos: 214

- Óbitos de menores de 1 ano: 4

- Coeficiente de Mortalidade Infantil: 18,7/1000 nascidos vivos

- Coeficiente de Mortalidade Neonatal: 4,7 (precoce+tardia)

- Coeficiente de Mortalidade Pós-Neonatal: 14,0\% N.V.

- Mortalidade Geral: 52/10000

Os dados acima, sobretudo os referentes à população de menores de um ano, apesar de se tratar de pequenos números absolutos (4 óbitos),

\footnotetext{
${ }^{6}$ Os dados aqui apresentados foram obtidos com o Diretor da Saúde e com o pessoal de saúde local, 10/1999.
} 
que podem interferir na análise, podem, à primeira vista, permitir uma leitura, a partir dos coeficientes apresentados, de que se trata de uma população em boas condições de saúde. O coeficiente de mortalidade infantil no Município - 18,7\% nascidos vivos, está abaixo da média do Estado de São Paulo que, por sua vez, ocupa uma posição diferenciada em relação à média do Brasil, como um todo, aproximando-se do apresentado por países de melhor condição de desenvolvimento sócio-econômico. Esse fato poderia dar idéia de que se trata de uma população que se encontra em uma fase de superação das principais causas de morte relacionadas à pobreza, tais como diarréia, doenças respiratórias, desnutrição, infecções. Entretanto, ao se levarem em conta os componentes dessa mortalidade, verifica-se que o componente pós - neonatal constitui aquele com maior contribuição - 14 \% n.v., enquanto o componente neonatal apresenta um coeficiente de $4,7 \%$ n.v., dando a entender que aquelas causas relacionadas à pobreza ainda estão prevalecendo como causas de óbito de crianças menores de um ano de idade em Morungaba, ainda que a MI, como um todo, apresente-se baixa, quando comparada com a média estadual e nacional, e de regiões mais pobres. Em função de não se contar com as causas de morte dessa população, fica difícil avançar na análise, porém seria interessante, igualmente, proceder-se a um estudo das causas de morte de crianças no período neonatal, diferenciando o componente neonatal precoce, do neonatal tardio, pois possivelmente, parte das crianças que estão morrendo nesse período, em Morungaba, o estão por causas associadas à assistência ao parto e ao recém-nascido, causas evitáveis, como aquelas da mortalidade pós-neonatal, fato constatado na maior parte dos municípios brasileiros. Da mesma forma, 
contar com dados de anos anteriores e de outras faixas etárias, além de outros referentes à atuação de serviços de saúde locais e a condições materiais de existência da população, em sua diversidade, poderia permitir ter uma idéia da evolução das condições de saúde da população do Município em estudo, identificando diferenciais, segundo grupos sociais distintos.

\section{Educação:}

A área da Educação ${ }^{7}$ conta com três Escolas Municipais de Educação Infantil, uma Escola Municipal de Primeiro Grau, uma Escola Estadual de Primeiro Grau, à qual estão vinculadas 5 salas de aulas que funcionam em bairros isolados, localizados na zona rural, além de 15 salas de aulas de Ensino Supletivo, vinculadas à Diretoria Municipal de Educação.

O Município conta com duas escolas particulares, que atendem a crianças de 3 a 6 anos e uma creche filantrópica, que assiste a crianças de 1 a 7 anos de idade.

O número de crianças de 0 a 7 anos, matriculadas em todas as escolas, é de aproximadamente 627, distribuídas da forma descrita no Quadro 5:

\footnotetext{
7 Os dados foram obtidos com a Diretora de Educação e Assessora da Prefeitura que atualmente é representante do Conselho Municipal de Saúde. Agosto de 1999.
} 
Quadro 5. Distribuição do número de alunos por escolas. Morungaba, $11 / 1999$.

\begin{tabular}{|c|c|c|}
\hline ESCOLAS & $\mathrm{N}^{\circ}$ & Alunos \\
\hline Esc. Mun.Educação Infantil & 3 & 281 \\
\hline Esc. Mun.Ensino Fundamental & 2 & 101 \\
\hline Esc. Estadual Primeiro Grau & 1 & 86 \\
\hline Esc. Estaduais Rurais & 4 & 24 \\
\hline Creche Filantrópica & 1 & 63 \\
\hline Esc. Educação Infantil Privada & 2 & 72 \\
\hline TOTAL & 13 & 627 \\
\hline
\end{tabular}

Fonte: Censo Escolar 2000. Diretoria da Educação e Cultura, Prefeitura Municipal de Morungaba.

Quadro 6. Distribuição do número de Professoras e Monitoras de creches envolvidas no Projeto de Saúde, que trabalham com crianças de 0 a 7 anos das Escolas de Morungaba, 2000.

\begin{tabular}{|l|c|c|}
\hline \multicolumn{1}{|c|}{ ESCOLAS } & $N^{\circ}$ de escolas & Professores \\
\hline Esc. Mun.Educação Infantil & 3 & 15 \\
\hline Esc. Mun.Ensino Fundamental & 2 & 4 \\
\hline Esc. Estadual Primeiro Grau & 1 & 2 \\
\hline Esc. Estaduais Rurais & 4 & 4 \\
\hline Creche Filantrópica & 1 & 5 \\
\hline Esc. Educação Infantil Privada & 2 & 5 \\
\hline \multicolumn{1}{|c|}{ TOTAL } & 13 & 35 \\
\hline
\end{tabular}

Fonte: Censo Escolar 2000. Diretoria da Educação e Cultura, Prefeitura Municipal de Morungaba. 
Realizada a caracterização do Município de Morungaba, torna-se importante neste momento, apresentar os sujeitos que participaram do presente estudo.

\section{4 - Sujeitos do estudo}

A população-alvo do estudo foi representada por parte da população beneficiária deste Projeto de Promoção da Saúde Ocular e Prevenção de Problemas Visuais no Município de Morungaba, em face do tempo reduzido e da pouca disponibilidade de recursos humanos:

a) mães com filhos com idade abaixo de 7 anos de idade, matriculados na EMEI São Benedito, residentes no bairro São Benedito, do município de Morungaba. Além de estar matriculada na EMEI, a criança deveria, também, estar matriculada nos serviços locais de saúde, para que sua mãe fosse incluída no estudo. O total de mães correspondeu a 150, aproximadamente;

b) pessoal de saúde: médico of talmologista e equipe de enfermagem, que estivesse trabalhando nos 2 equipamentos sociais de saúde no Município, perfazendo um total de 13 pessoas;

c) Professores da rede municipal, estadual e privada de educação que estivessem assistindo a crianças de 0 a 7 anos de idade total de 33 professores, incluindo orientadores pedagógicos e Diretora de Educação:

d) Pessoal da Pastoral da Criança: líderes e agentes comunitários. Total de 6 voluntários. 
Critérios de Inclusão:

- mãe ou responsável por crianças de 0 a 7 anos de idade;

- mãe ou responsável, residente em áreas mais carentes, no caso, no bairro São Benedito;

- mãe ou responsável por criança matriculada, tanto em serviços de saúde, como em equipamentos sociais de ensino, no caso, EMEI São Benedito, no bairro do mesmo nome, assim como alunos residentes na zona rural:

- mãe ou responsável, nas condições acima e que aceitasse participar livremente da pesquisa.

Critério de Exclusão:

- no caso de mães com mais de um filho na faixa etária selecionada, com requisitos para serem incluídas no presente estudo, as mesmas foram consideradas apenas uma vez.

\section{5- Etapas metodológicas}

Considerando a natureza do estudo proposto, qual seja, investigar processos de construção/movimento de participação social em uma dada realidade, fez-se necessário recorrer, fundamentalmente, a uma análise qualitativa que, por sua vez, foi complementada por alguns dados quantitativos para auxiliar na visualização da abrangência do processo, objeto de análise. 


\subsection{1- Coletas de dados}

a) Quanto aos instrumentos para a coleta de dados, foram utilizados:

- Diário de campo - foram registrados, por escrito, dados que o pesquisador considerou importantes na situação de campo para a descrição do Projeto e, principalmente, aqueles concernentes à participação dos atores sociais: eventos observados $e$ vivenciados pelo pesquisador:

- Fotografias - realizadas pelo pesquisador para ilustração dos eventos que foram desenvolvidos, diante da aceitação dos participantes. Exemplo de eventos: treinamentos, exposição organizada pela lider do setor da Educação e professores, a visita da televisão local na cidade (EP/TV).

- Questionário - O questionário (anexo 1) foi aplicado pelo pesquisador, mediante o consentimento livre e esclarecido dos sujeitos da pesquisa - pessoal de saúde, professores do primeiro grau ( $1^{a}$ série), educadores de creche, pessoal da Pastoral da criança e mães das crianças selecionadas. O questionário contemplou as seguintes questões: "Quais as ações/atividades em que o(a) Sr. (a)participou no Projeto Ver e Viver ?" e "Conte para nós um fato que marcou muito sobre a sua participação no Projeto de Promoção da Saúde Ocular" Anexos, o Termo de Consentimento Livre e Esclarecido (anexo 2), bem como o Termo de Responsabilidade do Sujeito pesquisador para com as Instituições e pessoas envolvidas (anexo 3); 
- Entrevistas - foram realizadas entrevistas, sempre que houve algum impedimento/dificuldade por parte dos sujeitos da pesquisa para o preenchimento do questionário. Estas foram gravadas pelo pesquisador, com o consentimento dos atores sociais participantes e lideranças locais:

Além dos instrumentos de pesquisa citados, outros também fizeram parte deste estudo:

- documentos sobre a história, política e economia sobre a cidade, disponíveis em Morungaba;

- ficha de preenchimento dos dados das crianças;

- ficha de encaminhamento das crianças para o oftalmologista:

- ficha para registrar a consulta realizada pelo oftalmologista.

A coleta de material foi realizada em um período de cerca de 7 meses, respeitando-se, sempre, a organização e disponibilidade do pessoal envolvido.

\subsection{2 - Organização e análise dos dados}

Terminada a etapa de trabalho de campo, procedeu-se:

- ao processamento das informações contidas nos instrumentos, utilizando-se o computador. Essas informações foram inseridas no Programa EPI-INFO (DEAN 1994);

- à apresentação dos dados coletados, que seguiu a ordem das temáticas apresentadas e, também, os momentos desenvolvidos no Projeto: 
- à leitura exaustiva do material organizado, buscando-se elaborar os núcleos de sentido que serviram de base para a análise posterior. Trata-se, como já dito, de uma descrição do desenvolvimento do Projeto com ênfase na questão da participação dos atores sociais:

- à apresentação das fotos e de entrevistas realizadas com os atores sociais, para complementação da descrição da primeira parte:

- à organização de dados do questionário e da entrevista, segundo o critério de frequiência numérica e percentual e apresentados sob a forma de tabelas e quadros.

- à descrição dos aspectos significativos da participação vivenciada no Projeto, segundo os atores sociais envolvidos: pessoal de saúde, professores do primeiro grau ( $1^{a}$ série), educadores de creche e mães. A organização desses dados foi feita segundo categorias de análise que foram construídas para cada grupo de atores sociais.

O eixo norteador de investigação do processo de participação vivenciado por atores sociais na construção de um projeto de promoção da saúde ocular e prevenção de problemas visuais do presente estudo, compreendeu dois níveis de análise: macro e micro.

Em nivel macro, a participação foi considerada na direção da promoção da saúde, quer dizer, na busca de ações estratégicas que visassem à transformação social, em que a saúde fosse tratada como um dos elementos essenciais da qualidade de vida da população. Assim 
entendida, foram considerados os componentes estratégicos de ação: a educação em saúde, o fortalecimento dos indivíduos por meio da criação de mecanismos de controle, intersetorialidade, interinstitucionalidade, possibilitando a construção concreta de redes de comunicação e de apoio por meio de parcerias.

Quanto à análise da participação em nível micro, ou seja, no nível da singularidade de cada ator social que se integrou $e$ foi integrado na construção coletiva deste Projeto, a participação dele quanto à quantidade de ações/atividades realizadas, descritas pelo pesquisador $e$ pelo próprio ator social, a forma como as realizou, permitiram distinguí-la em dois grandes tipos: participação transformadora e participação instrumental.

Denominou-se participação transformadora aquela apresentada por ator que passou pelo processo de treinamento sobre saúde ocular e que não apenas reproduziu os conhecimentos adquiridos, como produziu atos/ações, para desenvolver e trabalhar na área, de forma inovadora, criativa, e, principalmente, que transformou a intenção do pensar em ações concretas, isto é, passou do diálogo entre intenções à concretização de atos.

Para tanto, o ator social para ser situado nesse contexto, teve que demonstrar, necessariamente, ter-se apropriado do Projeto, como seu Projeto, ou seja, ter tomado para si o projeto, no sentido de transformálo, de forma consciente. Suas ações o indicaram ser o primeiro e o principal no desenvolvimento das ações. Foi considerado nesta categoria, aquele que puxa, carrega, que toma para si a responsabilidade de desenvolver o projeto. Em outras palavras, o ator social que demonstrou 
compromisso em avançar no processo, de assegurar uma apropriação formal do projeto pelo poder público, garantindo sua continuidade e avanço, foi categorizado como participante transformador.

Uma outra categoria de análise foi denominada participação instrumental: aquela em que o ator social, predominantemente, reproduz e multiplica as ações/atividades propostas, trabalhando no nivel do "saber fazer", sem criação, sem inovação.

Essas categorias de participação foram detalhadas durante 0 processo de análise, apresentado no capítulo Resultados.

Descrição dos significados de saúde ocular, promoção da saúde ocular e prevenção de problemas visuais

Com o objetivo de desvelar a percepção dos atores sociais sobre a temática da saúde ocular, promoção da saúde e prevenção de problemas visuais, conceitos-chave deste estudo, procedeu-se a uma investigação, de caráter qualitativo, para sua apreensão. Para tanto, a técnica de coleta de dados disponivel foi a do questionário que continha a pergunta: " $O$ que vem à sua cabeça quando pensa em saúde ocular?". Do mesmo modo, foi formulada questão para obter os demais conceitos, acima arrolados. Para aqueles que apresentaram alguma dificuldade em preencher 0 questionário, foram realizadas entrevistas pela própria pesquisadora.

A aplicação do questionário foi feita 4 meses após o treinamento de cada um dos grupos de atores - professores e monitores de creche, pessoal da saúde, voluntários da Pastoral da Criança e mães. A tomada de decisão quanto ao tempo decorrido para sua aplicação foi intencional, para que os atores sociais tivessem um relativo distanciamento do processo de 
treinamento e ao mesmo tempo tivessem já experienciado a parte que a eles competia no processo de planejamento, execução das atividades propostas. Em suma, consideraram-se os significados sobre a saúde ocular após os treinamentos e experiências de trabalhos vivenciados.

Desta forma, a intenção era conhecer as idéias associadas a cada um dos conceitos - saúde ocular, promoção da saúde e prevenção de problemas visuais -, visando identificar os núcleos de sentido em cada uma delas. É importante fazer aqui uma ressalva: procurou-se, durante as orientações para o preenchimento do questionário, esclarecer aos sujeitos do estudo que não se tratava, nesse momento, de avaliar os conhecimentos apreendidos $e$, sim, compreender o significado atribuído por eles a cada um dos conceitos apresentados.

Quanto à parte da organização dos dados coletados, os achados foram agrupados por grupos de atores sociais, acima citados, e no primeiro instante se fez a leitura vertical de todas as questões de cada um dos atores sociais para, em seguida, realizar uma releitura horizontal de todos os grupos de atores sociais.

Cumprida a primeira etapa, procedeu-se à análise do discurso, propriamente dito, de cada grupo de atores, procurando chegar a uma síntese de cada um dos questionários com as respectivas anotações do pesquisador, assim como à elaboração horizontal dos temas que afloravam no discurso. Em seguida, passou-se à primeira formulação de categorias, com o objetivo de situar nessas categorias os relatos de cada um dos atores, tomando-se o cuidado de não relegar nenhum deles.

A fase de delimitação de categorias foi repetida em três momentos distintos, pois, tratava-se de um diálogo entre o pesquisador e os textos 
de cada um dos atores sociais. Foi considerado fundamental para o desenvolvimento deste trabalho evidenciar um diálogo, que correspondesse realmente à rede de comunicação entre todos eles e não apenas do pesquisador com os discursos dos atores sociais.

Assim, passou-se à formulação final das categorias de análise para a compreensão da percepção da saúde ocular pelos atores sociais. Os achados foram situados em cada uma das categorias de análise $e$ apresentados no capítulo Resultados. 


\section{5 - RESULTADOS}

\section{1 - Descrição do processo vivenciado}

A descrição dos momentos de construção do Projeto de promoção da saúde ocular e prevenção precoce de problemas visuais, vivenciados no município de Morungaba, é apresentada, segundo os quatro momentos definidos em "procedimentos metodológicos": na realidade, esses momentos não aconteceram de forma linear, por vezes, concomitantes, expressando o dinamismo do processo $e$, por isso, dificultando a separação em momentos. Mesmo assim, para efeitos didáticos, a apresentação segue a sequiencia, para facilitar o acompanhamento das idéias básicas de cada um deles:

\section{P Momento - aproximação, investigação e conhecimento da realidade local, programação e elaboração do Projeto:}

O processo de trabalho iniciou-se em fevereiro de 1999, quando, pela primeira vez, a pesquisadora veio a conhecer a aconchegante Morungaba $e$ se deixou ser conhecida por seus moradores, de forma simples e sem compromisso, através de visitas casuais ao Município, conversas informais com as pessoas nas ruas, na Praça, no Centro de Saúde, e observação geral dessas pessoas, buscando informações sobre a vida na Cidade, a partir de uma aproximação menos formal e mais curiosa em apreender o cotidiano de seus moradores.

Sentindo necessidade de adiantar o assunto que a levara à Cidade com alguém da área da saúde, dirigiu-se à unidade básica de saúde para conversar com quem alí estivesse, encontrando aquela que, na época, era a 
Coordenadora de Saúde - uma senhora alta, esguia, que a tratou com muita educação, mas com uma certa pressa; apresentou-lhe a sua intenção de estar estudando a possibilidade de construir um Projeto de Saúde Ocular, junto com o pessoal da saúde e da educação, voltado para crianças de 0 a 7 anos de idade de Morungaba, o que ela achou muito interessante, sugerindo procurar a Prefeita e o Diretor de Saúde e de Educação, e para isso fornecendo nomes, locais onde encontrá-los, telefones e alguns dados de funcionários do Setor Saúde.

$E$ assim aconteceu: a primeira conversa foi com a Diretora de Educação, uma senhora magrinha, de extrema simpatia e ágil nas atitudes que, não só se mostrou interessada na proposta de trabalho, como forneceu indicações de como era o perfil da Prefeita, expressou suas idéias de como poderia estar organizando os professores para uma primeira reunião, comprometendo-se a levar a idéia do projeto à Prefeita, tão logo com ela se encontrasse.

Foi assim que se conseguiu marcar um encontro com a Senhora Prefeita e com o Diretor de Saúde. Ao se chegar à unidade de saúde para reunião com o Diretor, diante da disposição de acolhimento das pessoas, houve oportunidade para conversar sobre outros assuntos com os funcionários, tentando valorizar alguns aspectos da cidade e da cultura local, desde o clima agradável, às condições de qualidade de vida, até trabalhos que desenvolviam na unidade, enfim, obter elementos visando a um conhecimento mais amplo, que não só dados numéricos, para ir percebendo as possibilidades, ou não, de desenvolvimento da proposta.

Na reunião com o Diretor da Saúde, este deu a impressão de se tratar de uma pessoa interessada em novas propostas e que contribuíssem 
para o desenvolvimento de Morungaba, manifestando, inclusive, sua idéia de realizar, com ajuda do Conselho de Saúde, um estudo sobre número de domicílios na região rural do Município e dos bairros novos da Cidade. Ao se inteirar da intenção do projeto, não colocou nenhuma objeção, ao contrário, prontificou-se a propiciar o encontro com a Prefeita, assim como de lhe entregar, e ao Conselho Municipal de Saúde, o esboço do Projeto, para submeter ao conhecimento e aprovação dos mesmos.

Paralelamente a esse processo, recorreu-se ao IBGE e DATASUS para se obterem dados estatísticos e informações gerais sobre o Município, bem como a representantes locais para conhecer-se a história, a estrutura sócio-política e cultural da cidade, objetivando a elaboração da proposta do Projeto para apresentar à Prefeita $e$ ao Conselho Municipal de Saúde. Além disso, foram realizadas visitas a diferentes locais na Cidade como: a Casa da Cultura e Biblioteca Municipal, em busca da história de Morungaba, o Centro de Saúde, o Hospital local, o Cartório de Registro, a Igreja, os Bairros. Na época, ajuda de diferentes pessoas foi buscada, para se obterem orientações sobre locais onde determinados dados poderiam ser encontrados.

Aos poucos, foi-se construindo o conhecimento sobre a Cidade e seus moradores, do centro à zona rural, imaginando-se que tipo de Projeto eles defenderiam como sendo deles.

Finalmente, chegou o dia da reunião com a Prefeita. Decidiu-se não levar, nesse momento, o Projeto, pois a hora era apenas para conhecê-la. Chegando à Prefeitura, nos poucos minutos de espera, ficou-se a imaginar como seria a Prefeita: alta, gorda, com cara de brava? Enfim, em outras palavras, havia uma ponta de receio de que ela não autorizasse a 
construção do Projeto de Saúde Ocular no Município. Ao se entrar na sala, estava-se diante de uma senhora, com um olhar expressivo e acolhedor, com mãos bem cuidadas. Feitas as apresentações, no primeiro instante da conversa, ao serem relatadas as intenções do presente estudo, percebeuse um certo clima de suspense, que foi sendo amenizado à medida que se falou em pesquisa de doutorado e que seria coordenada e orientada por docente da Universidade de São Paulo, sem nenhum ônus para o Município. A conversa tomou outro rumo, sentindo-se em seus olhos que as portas da Cidade estavam se abrindo para o trabalho proposto e ela manifestou isto com palavras e atos, ao pedir que chamassem a Diretora de Educação para que fossem fornecidos todos os dados necessários para 0 desenvolvimento do Projeto, ficando de entrar em contato com o Diretor de Saúde para fazer o mesmo.

Foi solicitado um novo encontro para apresentação do esboço do Projeto para sua apreciação, assim como de outros líderes locais, tais como a Diretora de Educação e o da Saúde, o Presidente e os participantes do Conselho Municipal de Saúde.

No periodo de abril, maio e junho de 1999, foi a fase de conhecimento de diferentes atores sociais no Município, do setor saúde e, principalmente, da educação. A proposta de trabalho foi elaborada, considerando-se algumas informações-chave com eles obtidas, como aquela de que fazia mais de três anos que os professores não realizavam testes visuais em crianças de primeira série e que também o pessoal da saúde nunca havia recebido orientações sobre saúde ocular.

O trabalho de busca de dados e investigação da realidade local teve prosseguimento, para elaboração do esboço do Projeto, enquanto alguns 
acontecimentos políticos na cidade foram indiretamente influenciando a apresentação do rascunho do Projeto: o então Diretor de Saúde pediu demissão, ficando a diretoria de saúde sem titular, por cerca de quatro meses. Decidiu-se, então, apresentar o esboço do Projeto somente para a Prefeita e Diretora de Educação, em junho de 1999, dada a demora no preenchimento do cargo vago na Saúde e a necessidade de estar agilizando o processo.

O novo Diretor de Saúde assumiu apenas por volta de agosto de 1999 e a indicação dos novos membros do Conselho Municipal de Saúde estava por ser refeita. Assim que o Diretor se inteirou da dinâmica da unidade de saúde, surgiu a oportunidade de conhecê-lo e apresentar-the a proposta de trabalho. Ao conhecê-lo, percebeu-se que talvez não pudesse se contar com o seu envolvimento, pois se mostrou preocupado com outras questões. Entretanto, como já havia tomado conhecimento da possibilidade da construção do projeto, por intermédio da Prefeita, consentiu que se iniciassem os contatos com o pessoal da unidade e que fosse feita a apresentação do projeto ao Conselho Municipal de Saúde, por ele presidido.

Para a elaboração de parte desta proposta de Projeto, contou-se com a permissão da Diretora de Educação para realização de reunião com os professores, com a finalidade de conhecê-los e de aplicar um questionário, visando reconhecer o que traziam de informações sobre ações básicas de saúde ocular, e o interesse do grupo em relação ao tema -Saúde Ocular, identificando temas que gostariam que fossem abordados. Esse movimento em direção à Diretora de Educação possibilitou uma aproximação entre ela e a pesquisadora, criando um vínculo de parceria, 
desencadeando um processo de consultas mútuas para a organização de atividades que se seguiram, para a tomada de providências necessárias para assegurar a infra-estrutura e aproveitando intervalos para uma convivência social, sempre em um clima de cordialidade.

Desta forma, aconteceu a reunião com os professores, organizada pela Diretora de Educação e por duas coordenadoras pedagógicas. A recepção dos professores em relação à proposta de Projeto na área da saúde ocular foi muito boa, emergindo várias sugestões, entre elas, a de ampliar a faixa etária - incluindo alunos até a quarta série; manifestaram desejo de participar, querendo saber como e quando iria ter lugar o desenvolvimento das atividades. A relação que se procurou estabelecer com esses atores sociais foi mais horizontalizada, possibilitando conhecer suas experiências, reconhecer e valorizar o papel dos professores, seu trabalho árduo em sala de aula, as dificuldades pedagógicas enfrentadas, destacando a responsabilidade quanto à formação de cidadãos inseridos em realidades diversas $e$, não obstante tudo isso, a baixa remuneração a que são submetidos. Acredita-se que a conversa informal facilitou a aproximação, criando um espaço para a construção de vínculos mais sólidos. Ao final, ria-se ao se falar sobre outros assuntos, que não o de saúde ocular, levantados pelo grupo, contribuindo para a libertação da pesquisadora de qualquer rigidez metodológica, formal.

A colaboração dos professores foi deveras importante, à medida que, em linhas gerais, houve a identificação dos temas que deveriam ser abordados nos treinamentos, sabendo-se, de antemão, o que já conheciam.

A proposta de Projeto foi finalmente elaborada (Anexo 20), na perspectiva de um projeto social, com eixo na promoção da saúde ocular 
e, a longo prazo, visando à melhoria da qualidade de vida de crianças de 0 a 7 anos; para sua viabilização e sustentabilidade, o projeto se apoiou na construção de parcerias entre setores e intra-setores, com empresas locais (colaboração financeira), na participação de diferentes atores sociais como: líderes sociais e políticos, pessoal da saúde, professores e monitoras de creche, ONG (pessoal da Pastoral da Criança), mães e crianças, a partir de um processo de sensibilização e treinamento dos participantes para as questões da referida área.

A descrição do Projeto de Promoção da Saúde Ocular e Prevenção Precoce de Problemas Visuais encontra-se no anexo 20.

O trabalho foi caracterizado como um Projeto Social, a ser desenvolvido no município de Morungaba, buscando-se, junto com a população envolvida, informações gerais para a concretização do mesmo, bem como a articulação dos atores sociais para estabelecer possiveis parcerias.

Marcada, finalmente, a reunião do Conselho Municipal de Saúde, em cuja pauta constava a apresentação da proposta de Projeto, para lá se dirigiu a pesquisadora, sob uma forte chuva e falta de energia elétrica, o que prejudicou, parcialmente, os trabalhos do grupo. Mesmo assim, ocorreu a apresentação da proposta do Projeto e o Conselho foi unânime na aceitação, tendo, inclusive, apresentado sugestões e modificações no processo de trabalho: empresas que apresentavam potencial para integrar as parcerias; indicação e confirmação do bairro São Benedito como o mais carente do Município, auxiliando na definição de quais pessoas poderiam ser envolvidas no processo de trabalho: e estudo da possibilidade de ampliar a faixa etária das crianças, a ser incorporada no projeto. Apesar 
da manifestação positiva em relação à proposta, foi sentida uma certa dispersão e desânimo no ar entre as pessoas, talvez em função do horário e do cansaço das mesmas, depois de uma jornada de trabalho. Nesse dia, o Presidente do Conselho Municipal não compareceu à reunião.

Nova busca de dados foi empreendida, agora com outra finalidade: a de compor grupos em diferentes setores para a participação no processo.

Foi desta maneira que foi se dando o mergulho na "colméia de mel puro" que é Morungaba, conhecendo-se, dia após dia, os seus atores sociais, observando-se quase tudo, mostrando atenção e interesse para qualquer coisa que viesse deles. $E$ já, nessa fase inicial dos trabalhos, vinham convites para participar de pequenos momentos sociais que faziam parte da vida das pessoas, durante o dia, como tomar café com bolo na unidade de saúde ou um chazinho com bolachas com a Diretora de Educação, na Prefeitura. Nesses momentos, a vontade de morar em Morungaba e de fazer parte daquele mundo de calmaria vinha forte e, aos poucos, crescia a determinação de se trabalhar com o máximo interesse e desejar sucesso para a comunidade morungabense.

$2^{\circ}$ Momento-intersetorialidade e formação de parcerias

Após a aceitação do Projeto de Promoção da Saúde Ocular por parte do Conselho Municipal de Saúde, era fundamental a construção $e$ realização de parcerias locais entre os setores da Saúde, Educação, Esporte, Comunidade e Empresas, para envolvê-los no trabalho, tentando garantir o comprometimento dos atores sociais na realização do mesmo. 
Com essa intenção, sugeriu-se ao Conselho, por ocasião da reunião de apresentação do esboço de Projeto, que indicasse alguém que pudesse realizar, junto com a pesquisadora, as visitas às empresas locais, na condição de representante da Cidade, a fim de se buscarem parcerias junto às fábricas: duas pessoas se apresentaram como voluntários, colocando-se à disposição para essa incumbência.

A partir desse momento, passou-se a considerar não mais uma proposta de projeto e, sim, um Projeto, ficando claro que não era o pesquisador (EU) o único sujeito da ação, mas NÓs ( o sujeito pesquisador e atores sociais locais). Sentiu-se um certo conforto quando essa mudança substantiva foi percebida pois, estava-se entre parceiros, com quem se poderia, de certa forma, compartilhar responsabilidades, angústias, sucessos, incertezas e, principalmente, ter um espaço para re-pensar e re-formular a prática profissional, a partir de novos conhecimentos criados/re-criados e poder-se desenvolver/fazer crescer o compromisso, - respeito e envolvimento com a população local, que mal se acabara de conhecer.

Contando-se com o envolvimento e apoio de integrantes do Conselho Municipal de Saúde, ainda que de modo ainda tímido, foi agendada visita a algumas empresas locais, com uma pessoa do Conselho, em novembro de 1999, na busca de parcerias. Previamente à visita, foi feita reunião (o representante e a pesquisadora), com a intenção de se preparar a entrevista - como abordar o assunto e, ao mesmo tempo, ter-se uma idéia sobre o perfil das pessoas com quem contatar. A representante do Conselho que participou das visitas, era funcionária da unidade de saúde, atuando em vigilância epidemiológica, como técnica de enfermagem: muito 
simpática, sociável e rápida nas sugestões, conhecia muita gente na Cidade. Foram visitadas a Fábrica de Armações-Sorel e a Ótica N. Senhora do Belém, cuja sede se localizava em Itatiba.

Conseguiu-se a efetivação da parceria com a fábrica de armações, e seu Diretor colocou à disposição do Projeto 150 armações de óculos, em 3 tamanhos diferentes: a óptica fez a doação de lentes - 150 pares de lentes. Essas aquisições foram facilitadas pelo teor do Projeto, que objetivava atender a crianças de 0 a 7 anos, no que diz respeito à saúde ocular, garantindo ganhos publicitários com esse tipo de trabalho, isto é, 0 reconhecimento da parceria através da nomeação das empresas, divulgadas por todos os meios de comunicação utilizados no Projeto como: manuais, faixas, jornais, entre outros.

Essas parcerias foram formalizadas, mediante documento assinado pelo Presidente e representante do Conselho Municipal de Saúde, pelo proprietário e Diretor das empresas e pela pesquisadora, com o objetivo de selar o compromisso assumido por eles com o Projeto (anexo 7).

Sentia-se que a parceria com o setor de Educação já estava estabelecida "naturalmente"; tinha-se a sensação de conhecer a Diretora de Educação de longa data pois, quando das reuniões, havia uma sintonia nos pontos de vista e uma identificação no processo de envolvimento e de compromisso com o trabalho, a que se estava propondo fazer.

Mas, com o setor Saúde, a história foi diferente, não se reconhecia envolvimento da parte de seu Diretor, sobre cujas razões não se pretende discutir, talvez por falta de elementos mas, o que se percebia em seus olhos era uma falta de envolvimento com o que fazia, e, por conta disso, o projeto se deparou com um sério problema: um apoio pouco efetivo da 
Saúde. Depois da reunião do Conselho Municipal de Saúde, o Diretor ficou responsável pela entrega de cópia do Projeto aos funcionários das unidades de saúde, inclusive ao oftalmologista, na época afastado do serviço em licença-saúde, comprometendo-se a, ele próprio, estar comunicando a todos os seus funcionários.

À medida que as idas desta pesquisadora ao Município foram se intensificando, procurava-se, sempre, passar pela unidade de saúde para tentar saber se os funcionários tinham sido comunicados sobre o Projeto e se descobria que isto ainda não tinha sido feito, até que, após consulta à Diretora de Educação, decidiu-se, por conta do Projeto, assumir-se a conversa com os funcionários, sem maiores formalidades, $e$, inclusive, tentar-se um contato com o médico oftalmologista.

$O$ desafio estava lançado, pois não se conseguia contato com 0 profissional, por motivos vários. Solicitou-se, então, a uma das funcionárias da unidade que entregasse a proposta de Projeto ao oftalmologista, para ser lida e comentada e recomendando para que, se possivel, ele tentasse comunicar-se com a pesquisadora, via telefone.

O telefonema foi recebido, quando o profissional informou não estar sabendo de nada e solicitou esclarecimentos. Nada mais justo, pois ele seria um importante ator social, durante todo o processo de trabalho. $\grave{A}$ medida que foi sendo esclarecido, mostrou-se compreensivo, porém sem manifestar maior interesse em se envolver no Projeto, a não ser para expressar sua preocupação com relação à sua capacidade de, sozinho, atender à possível demanda aumentada em função do mesmo, diante do que foi solicitada uma proposta de horários para o atendimento de crianças do Projeto. Referiu, também, que não poderia realizar refração 
em crianças menores de 3 anos, uma vez que o serviço não dispunha de uma régua indicada para isso - técnica que dispensa a colaboração subjetiva do paciente. Esse impedimento foi rapidamente solucionado pela Prefeita que, ao tomar conhecimento, autorizou a compra do aparelho, o que foi considerado um dos ganhos do Município, obtidos com o Projeto.

A parceria com o pessoal da Pastoral da Criança não tinha sido prevista inicialmente. Pessoas muito singulares e com muita garra e entusiasmo se apresentaram como voluntários. Quem sugeriu a sua participação foi a assistente social do Centro de Saúde que com eles tinha contato, por intermédio do programa do leite: pesavam e mediam as crianças para avaliarem o seu estado nutricional e decidirem sobre a necessidade, ou não, de suplementação de leite. O Coordenador da Pastoral era uma pessoa especial, com quem a pesquisadora aprendeu a lidar com as diferenças sociais. Arregaçava as mangas, pegava o seu carro e a levava para a roça para triagem de crianças da zona rural - ele e mais algumas mulheres batalhadoras que, em dias em que não faziam faxina em casas de família, estavam ajudando a Pastoral; havia outras que trabalhavam à noite na fábrica, cuidavam de sua casa e de sua família $e$, ainda, arranjavam tempo para se dedicarem às crianças da Pastoral.

Em julho de 2000, a pesquisadora teve um encontro com a coordenação da Pastoral da Criança no Município, mais uma vez com a ajuda da Diretora de Educação, que providenciou o telefone para contato com o Coordenador. Ele achou muito interessante a proposta, transpareceu uma ponta de orgulho por poder trabalhar no Projeto $e$, assim, foi estabelecida a parceria com essa organização não- 
governamental atuante no Municipio, ainda que sem nenhum instrumento formal.

Foi marcada a reunião com os colaboradores da Pastoral para apresentação do Projeto, também com a ajuda da Diretora de Educação, que cedeu o espaço físico para a realização dos eventos - a Casa da Cultura -, em horário fora do expediente, alocando uma funcionária da Prefeitura para cobrir o período de trabalho.

Foi estabelecida, também, parceria com a Diretoria de Esportes/Lazer, que funcionava na mesma sala ocupada pela Educação $e$ sempre que possível, participava do chá, que reunia os Diretores de Educação, de Esportes e Lazer e esta pesquisadora. Foi assim que ele começou a se inteirar do trabalho e a apresentar sugestões, inclusive, chegando a redigir matéria sobre o Projeto para o jornal que circulava no Município, a fim de divulgá-lo (anexo 8).

As responsabilidades foram sendo estabelecidas, à medida que o Projeto ia sendo adotado como compromisso, com maior ou menor envolvimento de cada setor.

O trabalho foi tomando forma de projeto social, à medida de seu desenvolvimento processual, para o que a proposta inicial de projeto pode ser considerado como instrumento mobilizador das demais etapas do processo, um espaço de inter-relação entre o saber e a vivência da pesquisadora/ator social e os saberes e vivências dos outros atores sociais.

A construção de parcerias, nesse momento, representou a concretização parcial de uma estratégia considerada importante para a 
viabilização e sustentabilidade do Projeto, implicando ganho para o Município.

$3^{\circ}$ Momento - reaproximação, divulgação e execução do Projeto de Saúde Ocular:

A reaproximação com a comunidade buscou, nesse momento, um refinamento das parcerias, com vistas a garantir o comprometimento de diferentes setores em desenvolver a proposta básica de trabalho.

Nessa etapa, foi importante observar e identificar mais claramente os atores sociais que, efetivamente, estavam envolvidos no processo de construção do Projeto e, em conjunto com eles, procurar algo que pudesse motivar os demais participantes.

Segundo DIAS (1998), para desencadear o processo de participação popular deve-se adotar uma atitude fundamental de escuta respeitosa, tentando ressaltar a auto-estima das pessoas. Concordando plenamente com a autora, procurou-se seguir o seu ensinamento, como um princípio a nortear a relação pedagógica com e entre os participantes do processo, pautada no pressuposto de reconhecer o outro enquanto sujeito portador de saberes e de experiências significativas, capaz de contribuir para 0 crescimento do grupo e de si mesmo nas relações. $O$ aprendizado, nesse processo, foi que os resultados a que se chega, mediante um processo de trabalho, nas bases acima colocadas, são qualitativamente diferentes $e$ mais enriquecedores, requerendo-se, para isso, a abertura dos participantes para novos aprendizados.

Com tudo isso, foi necessário reconhecer os integrantes que iriam efetivamente participar dessa construção, com suas realidades 
específicas: professores/escolas, pessoal da saúde/unidades de saúde, Pastoral da Criança/comunidade e crianças da faixa etária selecionada.

A reaproximação com professores e auxiliares de creches fluiu de forma amena, como seria esperado entre velhas companheiras.

Após a primeira apresentação da proposta, percebeu-se a possibilidade de ter que se enfrentar certa dificuldade com um grupo pequeno de professores e que acabou se confirmando, logo no primeiro dia de treinamento.

Esse grupo se colocou de forma a dar a entender que não estaria interessado, interferindo no bom andamento dos trabalhos. Ao final do evento (primeiro treinamento), a coordenadora pedagógica da escola, local do treinamento, houve, por bem, lamentar o ocorrido, ficando de relatá-lo à Diretora de Educação.

Nesse mesmo dia, houve uma breve reunião com a Diretora, que havia sido marcada previamente para se decidirem algumas estratégias de divulgação, ocasião em que foi solicitado o relato de como havia transcorrido o treinamento. A pesquisadora comentou sobre o acontecido naquela manhã com o grupo de professoras, com a intenção de evitar uma possivel situação embaraçosa, ao receber a informação de outros participantes. Lamentando o ocorrido, referiu que já havia tido vários problemas com esse mesmo grupo, em outros eventos. Disposta a conversar com o grupo, foi-lhe solicitado que não o fizesse, pensando-se na possibilidade de que pudesse vir a criar outros entraves para 0 desenvolvimento dos trabalhos.

Refletindo sobre a questão, resolveu marcar uma reunião com as professoras para discutir coletivamente sobre a participação, 
dificuldades sentidas, assim como a liberdade de decisão de cada um em continuar ou desistir da empreitada. Essa conversa aconteceu apenas com as professores das escolas municipais, às quais estava ligado aquele grupo resistente à sessão de treinamento. A Diretora de Educação retomou os objetivos do Projeto, deixando um espaço para que os professores colocassem suas preocupações. Foi aí que uma das professoras do referido grupo expressou sua opinião de que o Projeto continha atividades que, em sua leitura, seriam de competência do pessoal da saúde. Além disso, considerava difícil conseguir aplicar os testes.

Diante dessa situação, a Diretora relembrou que a participação não era obrigatória $e$, portanto, eram livres para participarem, ou não, do Projeto. Entretanto, ressaltou o prejuízo que a ausência acarretaria, não só para o professor desistente, em termos de aquisição de novos conteúdos, mas, sobretudo para as crianças, que continuariam sem ter o acesso à saúde ocular. O grupo, razão da reunião, explicitou a decisão de permanecer no Projeto e participar de todas as etapas de trabalho. Apesar disso, percebia-se certa desconfiança do grupo em relação ao trabalho de acompanhamento do processo, de responsabilidade da autora, que envolvia visita a todas as unidades educacionais participantes. Estava previsto que o acompanhamento iria iniciar pela escola localizada na zona rural, sob a responsabilidade de uma das professoras do referido grupo e com a qual seria agendado o dia da visita já nessa reunião. Ao fazê-lo, notou-se de imediato a mudança de sua postura: um sorriso suave apareceu no seu rosto, e, no dia da visita, a recepção contemplou café, leite e biscoito na escola, o que foi considerado o selo de uma aliança importante. 
A Diretora da Educação, em resposta a uma reivindicação de alguns professores nessa mesma reunião, que relataram necessidade de tempo para o planejamento do trabalho com saúde ocular em sala de aula junto a crianças de 0 a 7 anos - abriu um espaço para que eles, em uma manhã de plane jamento, se organizassem e se reunissem, discutissem, trabalhassem em conjunto, decidindo sobre o processo pedagógico, assim como sobre técnicas e material necessário para essa atividade.

No processo de buscar o maior envolvimento de professores $e$ pessoal de Saúde, mediante sua participação no desenvolvimento do Projeto, com eles foi planejada a divulgação do mesmo, assim como a montagem do material que seria utilizado com as crianças. $O$ primeiro ponto a decidir foi o nome do Projeto e o "slogan". Vários nomes foram sugeridos e o mais votado foi "VER E VIVER! Construindo um Projeto de Promoção da Saúde Ocular". Feito isso, procedeu-se à confecção do material que seria utilizado na triagem de crianças menores de 5 anos de idade - a montagem das mãozinhas - e à escolha de nomes dos personagens criados para o Projeto. Outra decisão coletiva foi tomada sobre a forma final de trabalho pedagógico sobre saúde ocular com crianças em sala de aula, a partir do sub-projeto elaborado e apresentado pelo grupo de professores (anexo 9). Para isso, foram realizadas discussões em grupos, trocas de experiências no que diziam respeito à metodologia pedagógica mais apropriada, a ser utilizada com as crianças, com o objetivo de facilitar o processo ensino-aprendizagem de conteúdos sobre saúde ocular.

No grupo, surgiu a idéia de ampliação da divulgação, para além dos muros escolares, mediante confecção de faixas com o "slogan"do Projeto, 
com vistas a esclarecer a população e convidar mães para levarem seus filhos à unidade de saúde para realização da triagem visual, assim como chamar a atenção das crianças para o tema (Fig. 3 e Foto 3).

Vale, neste momento, descrever sucintamente os materiais criadose recriados para o Projeto, a partir da participação de professores, que representaram inovações a serem introduzidas, também, em outros processos de capacitação na área em questão.

Como primeiro passo, foram discutidas com o grupo possíveis atividades a serem desenvolvidas, para resgatar a importância do bom funcionamento dos olhos para a saúde geral das pessoas. Isso implicou sensibilizar e possibilitar a aprendizagem/reaprendizagem dos envolvidos do que é ter visão, dos cuidados que permitem a sua manutenção, das possibilidades assistenciais existentes ou por se criarem, dos direitos do cidadão em relação à questão. Para isso, foram utilizadas diferentes técnicas de dinâmica de grupo, apropriadas para propiciarem reflexão e sensibilização, baseadas na experiência profissional da pesquisadora $e$, dentre elas, algumas propostas por GONÇALVES e PERPÉTUO (2000). Trabalhou-se com a prática do reconhecimento dos olhos, enquanto órgãos. 
Fig. 3 - "Slogan"do Projeto de Saúde Ocular, Morungaba - SP, 2000

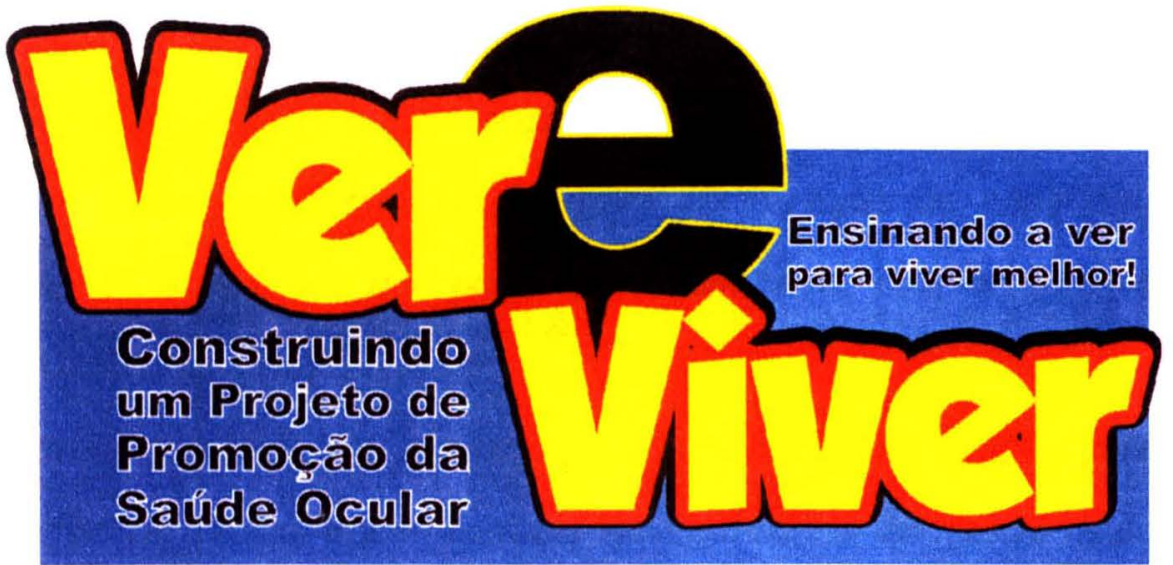

Foto 3 - Faixa do Projeto Ver e Viver, afixada na fachada do Serviço de Assistência Social N. Sra. da Conceição.

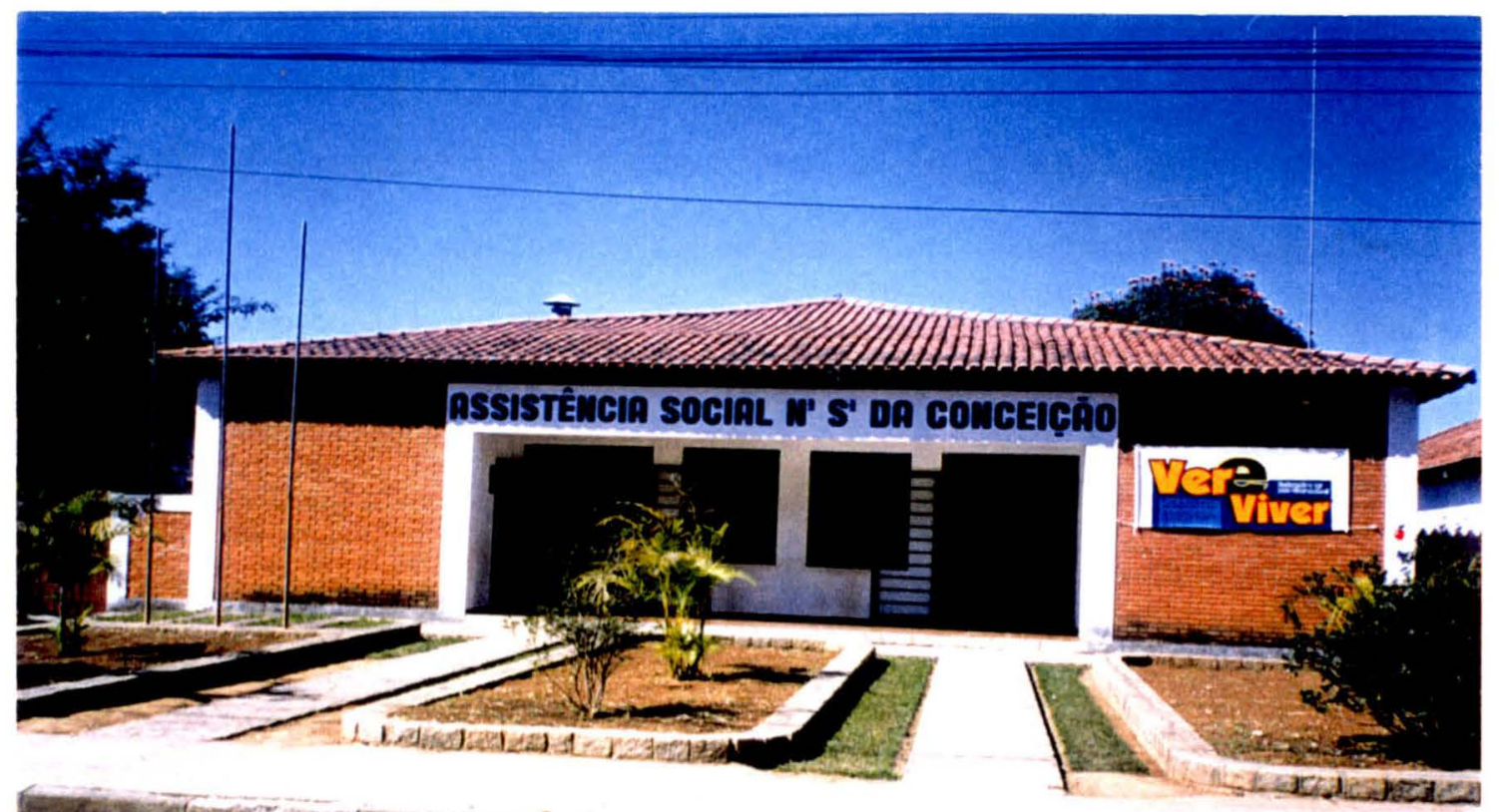


Em resumo, o treinamento fugiu do esquema clássico de aula, em que se supõe a relação entre alguém que "sabe" e alguém que "não sabe", este numa condição de simples receptor de conteúdos transmitidos pelo primeiro, para assumir uma relação de trocas, uma reciprocidade entre os participantes, visando à construção coletiva de estratégias pedagógicas adequadas aos propósitos do Projeto, na direção da constituição de sujeitos críticos, ainda que partindo de um tema, aparentemente muito específico e restrito.

Foi apresentada, a título de contribuição ao grupo, para suas atividades de ensino-aprendizagem de conteúdos de saúde ocular com crianças, a possibilidade de se utilizarem, como técnicas, alguns jogos infantis conhecidos, tais como: cabra-cega, andar sobre a linha com os olhos fechados, além de outras, do tipo: fazer o reconhecimento de pessoas com quem não convivem no dia a dia, apenas pelo som da voz; escrever algo em uma folha de caderno, com linhas, com os olhos fechados: tocar seu próprio globo ocular e olhá-lo no espelho.

Como apoio pedagógico para o treinamento, foi elaborado um "manual", com o objetivo de servir de instrumento de referência, com conteúdos básicos sobre saúde ocular, a que os participantes pudessem recorrer, quando sentissem necessidade. Essa iniciativa foi pensada desde o início do processo, ganhando força no segundo momento do trabalho, aprimorando-se a idéia a partir da definição de conteúdos sobre saúde ocular considerados importantes para serem abordados no treinamento, após a aplicação de questionários com alguns professores, para identificação de conhecimentos que detinham sobre o tema em estudo. 


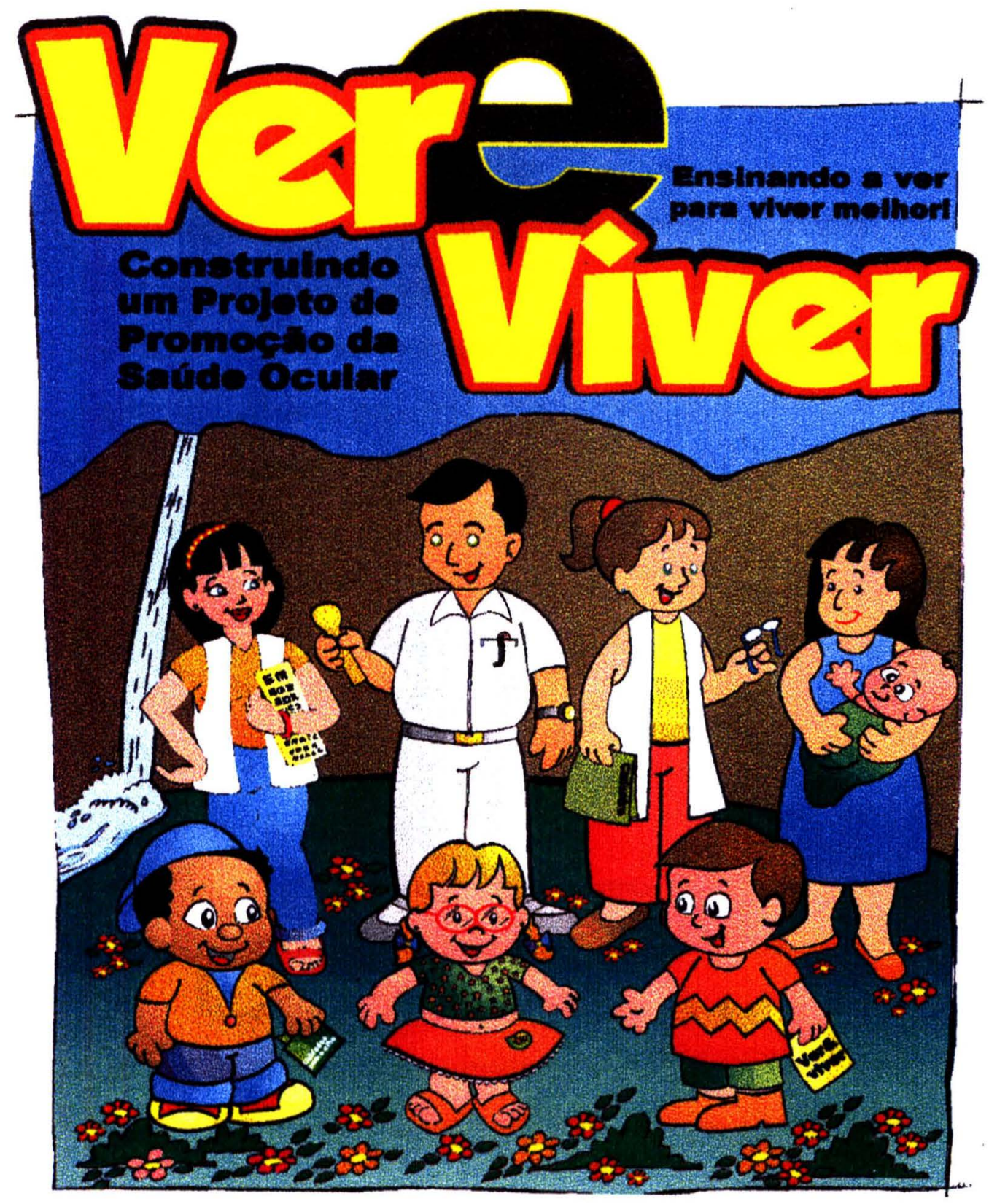


A construção desse manual foi paulatina, pois pensava-se em um material que, pela sua própria forma de apresentação facilitasse a consulta e a compreensão de seu teor, de uma forma didática, levando em conta as características dos componentes de cada grupo envolvido. Em relação ao conteúdo, ao se conhecer mais de perto a diversidade do grupo, logo se constatou que um único manual para todos, não seria apropriado para os fins a que se destinava, mesmo porque as tarefas eram diversificadas, segundo o papel de cada grupo, requerendo a adequação dos conteúdos à realidade, assim como da linguagem. Diante disso, foi produzido um manual com conteúdos mínimos necessários sobre saúde ocular, utilizando vocabulário mais simples, com ênfase em ilustrações, imagens, voltado para pessoas com certa dificuldade para a leitura, como algumas mães e alguns integrantes da Pastoral da Criança. E outro, um pouco mais complexo, diferenciando do primeiro na forma de abordagem das informações do assunto, utilizando linguagem técnica (anexos 4 e 5 , respectivamente).

Todos os participantes receberam o manual correspondente, durante o processo de treinamento.

A reprodução da maioria desses manuais foi feita em parceria com a Diretoria da Educação, com apoio da Prefeitura Municipal de Morungaba.

Dando continuidade à proposta de buscar material de apoio pedagógico, dentro de um espaço de criação/recriação, tomando-se por base os materiais existentes, surgiram 7 personagens para o Projeto, que foram utilizados na capa dos manuais (Fig. 5). O objetivo desse material era que os atores sociais o adotassem como auxiliares de trabalho com as crianças, conforme referido anteriormente, e fosse sugestivo para 
algumas situações, como montar um teatro com historinhas sobre a saúde ocular e que facilitasse a interação com crianças.

Uma outra iniciativa foi a criação de um jogo chamado Olho Mágico, útil para fixar os conhecimentos básicos de saúde ocular, sendo um jogo interativo, utilizado ao final de cada treinamento com os participantes para realizar um resumo do que havia sido trabalhado em grupo, relacionando o conteúdo teórico ao prático. O pré-teste desse jogo foi feito com o pessoal que trabalha em uma creche da USP, que assiste a crianças de 2 a 7 anos e fica localizada junto à Faculdade de Saúde Pública ( Foto 4).

A partir dessa experiência, com a assessoria de uma docente do Departamento de Saúde Materno-Infantil da FSP/USP, foram realizados alguns reparos técnicos com relação ao jogo para, em seguida, serem aplicados com diferentes grupos de atores sociais, participantes do Projeto em Morungaba. Basicamente, o jogo Olho Mágico consiste na brincadeira de acerto e erro entre dois grupos.

Outro material, criado e desenvolvido por atores sociais de Morungaba, com o apoio da Prefeitura Municipal e da Diretoria de Educação, foi a produção de um filme com crianças, professores $e$ monitores de creche, em situação de ensino-aprendizagem sobre ações básicas de saúde ocular. Esse filme foi projetado durante o evento da Exposição na Casa da Cultura, dando a oportunidade aos pais de apreciarem os resultados parciais dos trabalhos de seus filhos $e$ das professoras em relação ao Projeto de Promoção da Saúde Ocular e Prevenção Precoce de Problemas Visuais. 
Fig. 5 - Personagens criados para o Projeto
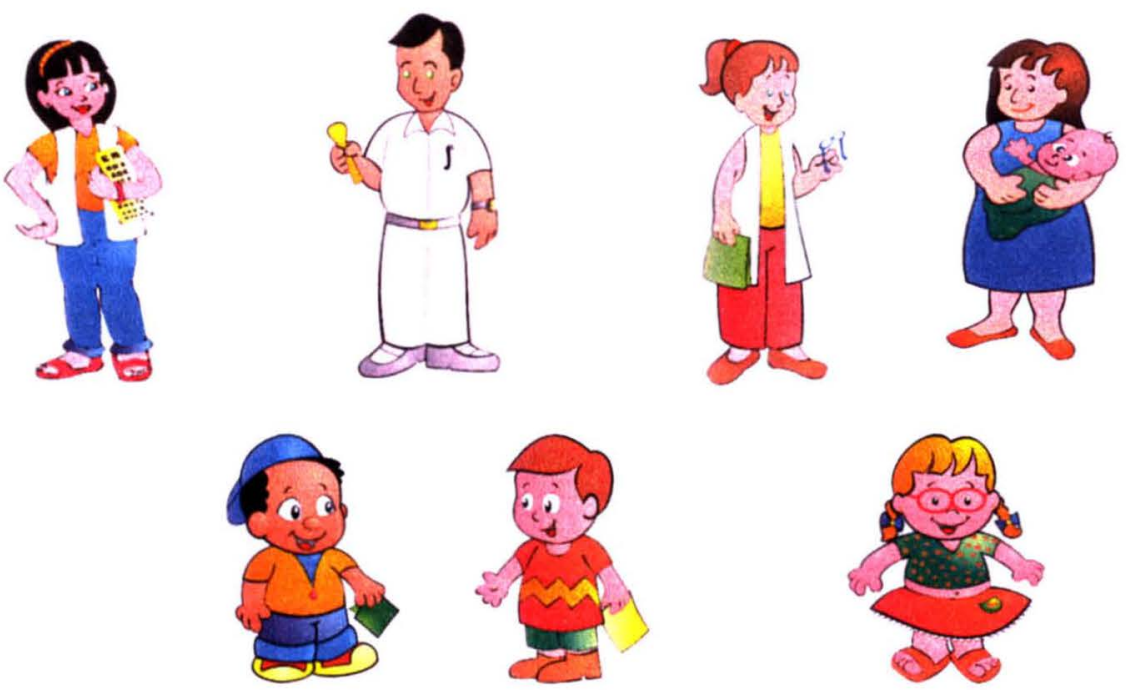

Foto 4 - Sessão de treinamento com Professores

Jogo Olho Mágico.

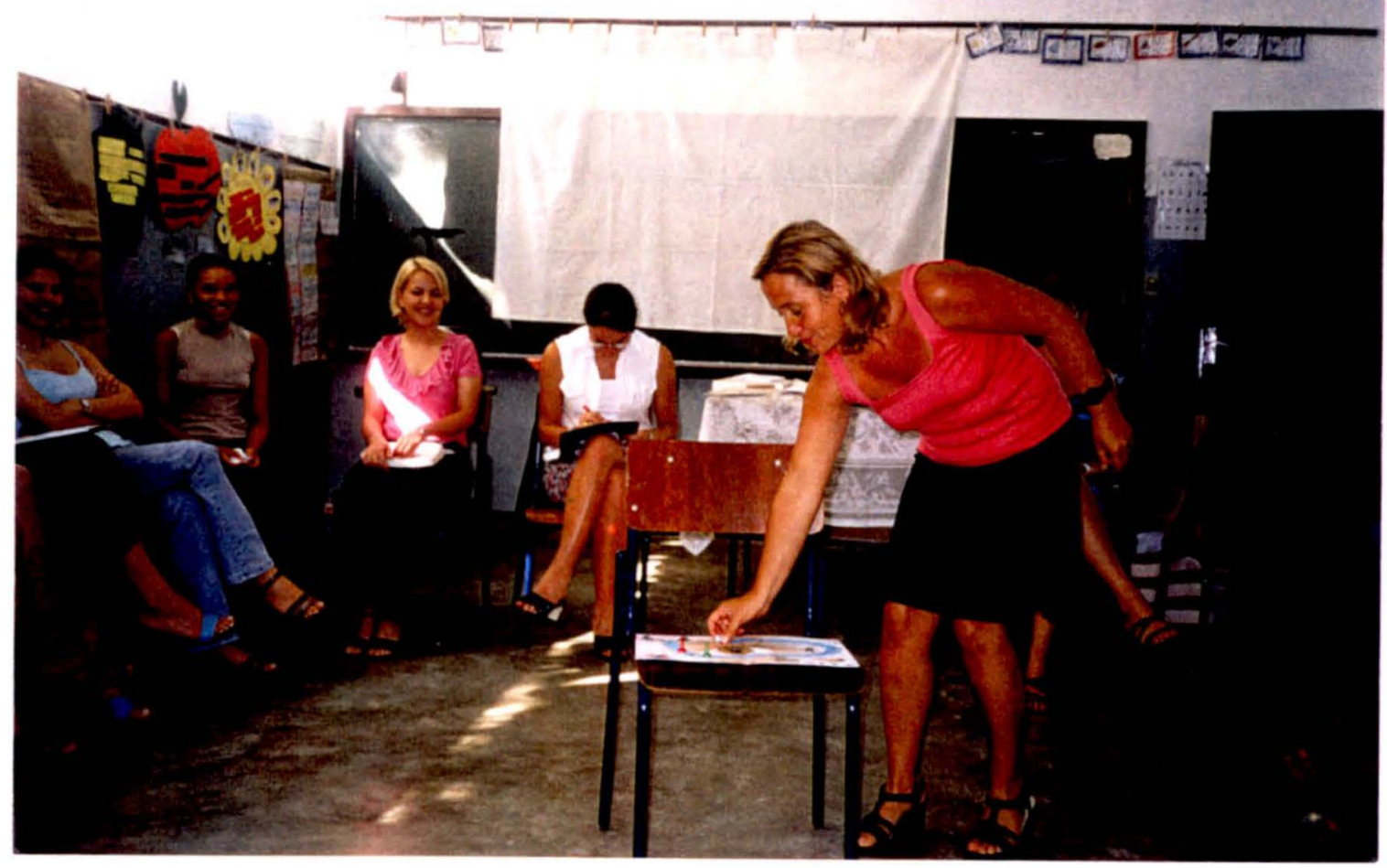


Foi elaborada no início do Projeto e anexada ao Manual uma ficha de saúde ocular para ser preenchida para cada criança triada em escolas, creche, comunidade ou centro de saúde, com alguns dados de saúde da criança, sinais e sintomas visuais, os testes de visão aplicados, resultados e observações do professor. Criou-se, também, uma ficha de encaminhamento para o oftalmologista, com dados de identificação de cada criança encaminhada e com resultado da triagem realizada por diferentes atores sociais (anexo 13).

A Diretoria da Educação enviou correspondência a todos os professores, convidando-os para o encontro sobre saúde ocular, que iria ocorrer no Município em data estabelecida previamente pelo próprio grupo, para apresentação da proposta do Projeto.

A execução deste Projeto na área da Educação teve seu início no dia 12 de abril de 2000, primeiro dia de treinamento de professores na direção da construção prática do Projeto para a Cidade, com a presença de todos os professores e monitores das Creches e Escolas Municipais, Estaduais e Privadas, que trabalhavam com crianças de 0 a 7 anos. Ao todo, foram 28 pessoas, presentes durante quatro horas, em um local definido pela Diretora de Educação e coordenadoras pedagógicas.

Além da discussão e definição da metodologia de trabalho para a implantação do Projeto, foram objeto de discussões: a promoção da saúde e prevenção de problemas; o Sistema Único de Saúde; os direitos do cidadão em relação à sua saúde ocular; o que pode ser feito em relação à saúde ocular de crianças; a relação entre educação e saúde e principais sinais e sintomas de problemas visuais. Nesse dia, foi ressaltada a importância das professoras e das orientadoras pedagógicas em seu papel 
educativo junto aos pais das crianças, para divulgação do Projeto, assim como nas estratégias de ação nas escolas em que atuavam (Foto 5).

Ao final desse encontro, houve oportunidade de se vivenciar uma experiência muito interessante, agradável e saborosa: a Diretora de Educação havia providenciado, especialmente, um almoço na escola, para que esta pesquisadora saboreasse com a Diretora da Escola e a Coordenadora Pedagógica, em sua cozinha-piloto, onde havia ocorrido o treinamento. Foi um momento de descontração, apesar da vergonha inicial.

Esse almoço havia sido providenciado, em função de a Diretora ter conhecimento da programação, segundo a qual a pesquisadora passaria o dia todo no Município, primeiro para o treinamento de professores das escolas municipais, alguns da escola estadual, das escolas privadas e da creche e, à tarde, para a mesma atividade com professores da escola estadual, impossibilitados de participarem no período da manhã.

Nesse mesmo dia, no encontro com os professores estaduais, às 13:00 horas, outra surpresa: a Diretora da unidade escolar resolvera adotar o Projeto como uma das atividades curriculares, lançando a idéia de ampliar, na sua escola, a faixa etária proposta no trabalho, para englobar os alunos das quatro séries, portanto, crianças na faixa etária acima de 7 anos. Baseando-se no Projeto, fez modificações, elaborou um projeto que chamou de Saúde Ocular, junto com os professores e coordenadoras pedagógicas. Desta forma, nesse dia estavam presentes professores que davam aula para crianças de primeira à quarta série. Esse trabalho funcionou integrado com o Projeto, mas com algumas atividades paralelas (anexo 10). 
Foto 5 - Reunião dos professores e educadores de creche para definirem como seria o projeto de saúde ocular em sala de aula, Morungaba - SP, 2000.

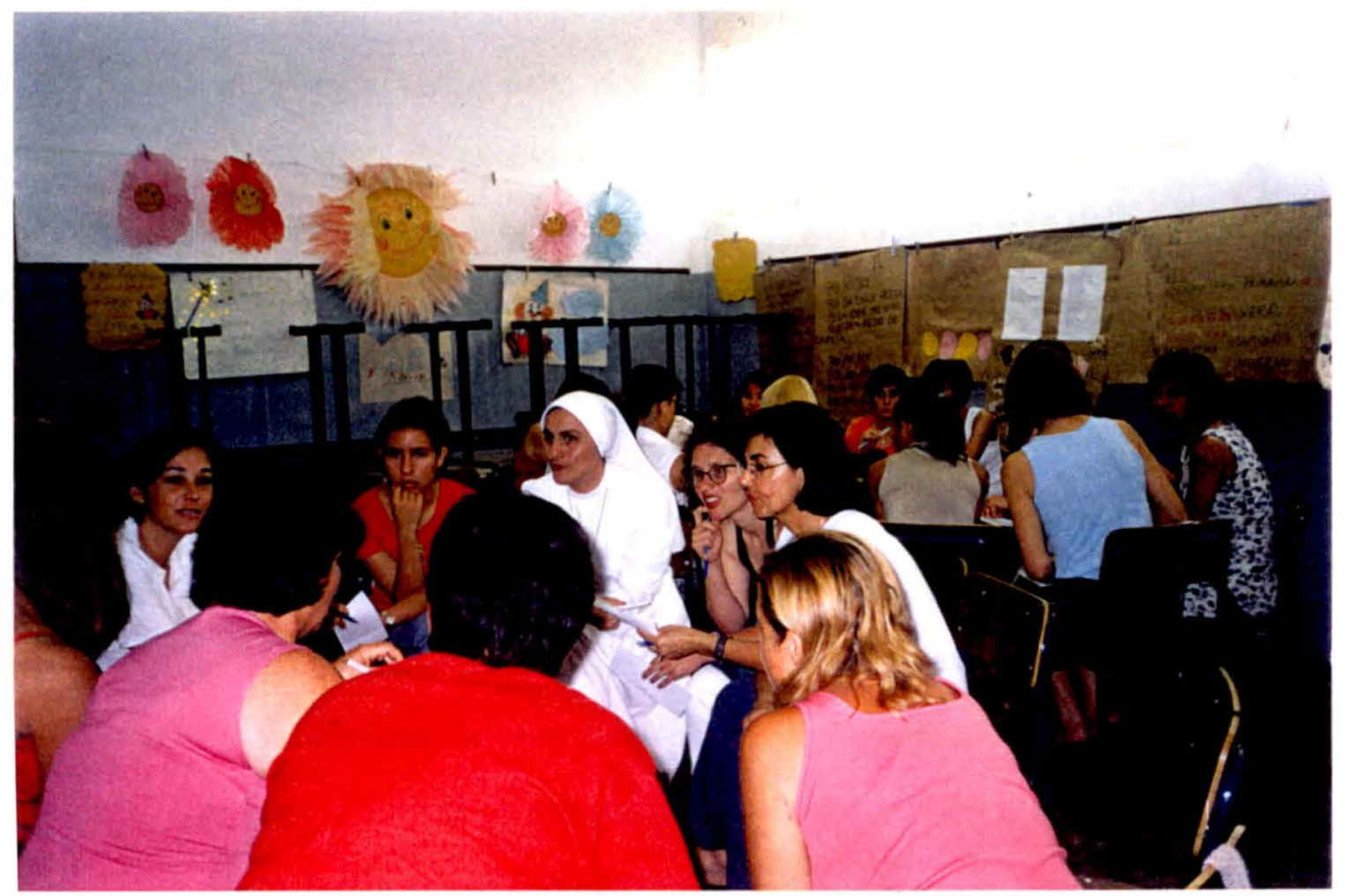


A fala da Diretora da Escola expressa bem o que sucedeu nessa escola:

"Ana, aqui na Escola tivemos a idéia, após a apresentação da proposta de Projeto de Saúde Ocular por você, de desenvolver um projeto ampliando a idade das crianças para até as quartas séries e envolvendo os professores destas séries no trabalho, você acha que teria problema?"

De uma pasta, retirou e mostrou o projeto recriado por ela, pela coordenadora pedagógica e pelos professores.

A resposta foi de acolhimento da proposta, a qual representou, na leitura da autora deste trabalho, a apropriação das ações de saúde ocular como algo importante para a vida das crianças, incorporando-as como responsabilidade da escola, resultado que jamais se poderia ter esperado para aquele momento inicial do processo. Perplexa e feliz, ao mesmo tempo, a pesquisadora colocou-se à disposição do grupo para ajudá-lo a construir o projeto reelaborado para essa escola.

A impressão que se teve era que o processo de participação dos professores estaduais se dava de forma mais solta e crítica, dentro de um clima de liberdade de expressão, observável durante o treinamento, em que eram mais críticos em relação às obrigações/deveres do Estado e mostravam clareza de seus direitos, enquanto cidadãos.

A Escola Estadual apresentava-se bem cuidada, mas guardava as marcas do tempo, os alunos aparentavam serem pertencentes a camadas sociais de baixa renda, mostravam-se alegres e risonhas. Conhecendo os alunos de todas as salas, de primeira à quarta série, foi feito o acompanhamento do aprendizado prático na Escola junto com os professores. 
Em um dia de calor, ao se chegar a essa mesma Escola Estadual, uma professora de quarta série veio ao encontro desta participante, com um olhar meio preocupado e disse:

"Sabe, depois do treinamento passei a observar os olhos dos meus alunos e percebi que uma aluna minha tem como se fosse uma minhoquinha dentro de um olho e ao fazer o teste nela deste mesmo olho, ela não enxerga nada, você pode dar uma olhada para mim?"

A aluna foi chamada, sem causar alarde, para que se procedesse à triagem, tendo sido constatado que ela apresentava sinais de catarata naquele olho, confirmado posteriormente, pelo oftalmologista do Município, que a encaminhou a um serviço de maior complexidade, em Jundiaí.

Tratava-se de uma menina bonita, mas aparentemente marcada pela vida: chinelos de dedo coloridos, as roupas rasgadas e um olhar triste. A professora relatou que era catadora de latas nas ruas, junto com a mãe e irmãos. Foi solicitado à professora que acompanhasse a situação oftalmológica da menina e que procurasse a pesquisadora, diante de qualquer problema.

Torna-se relevante esclarecer, aqui, que ao mesmo tempo que ocorria o treinamento à tarde, nessa escola, alguns professores estaduais participavam do treinamento da manhã junto com os das escolas municipais, creche e privadas.

No dia 26 de abril de 2000, foi realizada a segunda etapa do encontro com os professores (os que não podiam estar neste dia, eram apenas alguns professores da Escola Estadual), durante quatro horas, que 
constou de revisão dos conceitos elaborados no momento anterior: cuidados e higiene ocular; discussão sobre a operacionalização do conteúdo específico de saúde ocular com crianças de 2 a 7 anos, em sala de aula, e os testes de acuidade visual, realizando a parte prática entre elas. Nesse dia, foram combinadas as datas de visitas às unidades escolares para conhecimento da realidade das escolas e para o acompanhamento prático do aprendizado, com espaço para atendimento individual a professores para solucionar possíveis dúvidas.

Ainda nesse dia, foram discutidas, também, alternativas de trabalhos pedagógicos em sala de aula com crianças, trocando idéias e experiências anteriores.

Em maio, iniciou-se a atividade de visitas às Escolas. Foi um momento agradável, mistura de carinho, aprendizado e reconhecimento. Conseguiuse cumprir a meta de visitar todas as Escolas de Morungaba, que atendiam crianças com idade abaixo de 7 anos.

O objetivo dessas visitas foi acompanhar professores no desenvolvimento das atividades específicas, solucionar dúvidas relativas a procedimentos técnicos nas atividades propostas e conhecer a realidade de cada professora, como já foi referido em parágrafos anteriores.

Todas se preparavam para receber a pesquisadora, até as crianças: algumas Escolas, que já estavam desenvolvendo as atividades, mostravam - trabalho pedagógico em sala de aula, em relação ao conteúdo de saúde ocular de seu subprojeto; outras estavam se preparando para a reunião com as mães para esclarecerem sobre a programação a ser desenvolvida com seus filhos, em relação à saúde ocular, enquanto algumas professoras estavam recriando a forma e dinâmica do trabalho na sua Escola. A 
maioria delas já havia preparado, com a colaboração das crianças, cartazes sobre os olhos para afixarem na sala de aula e nos corredores e, em algumas Escolas, presenciaram-se grupos de crianças discutindo sobre a saúde e cuidados com os olhos (Foto 6 e Foto 7 ).

"Vamos pegar a massinha $e$ tentar fazer um olhinho... [falava a professora do jardim]."

"Vamos brincar de cabra cega? Se nós tamparmos os olhos não conseguimos ver os amiguinhos, a árvore da escola e nem a escola. "[Conversavam a professora e a monitora de creche com as crianças de três anos].

Quando se chegava às Escolas, fazia-se questão de conhecer as crianças de todas as salas de aula. Em primeiro lugar, a elas se se apresentava e com elas conversava-se um pouco, elogiando-as pelos trabalhos produzidos, quando estavam expostos, e depois disso, procediase em conjunto, a professora e a pesquisadora, à triagem visual em umas duas crianças, para verificar se havia alguma dúvida, e se preenchía a ficha de saúde ocular, seguindo a orientação de manter uma cópia na Escola.

Após a supervisão prática do aprendizado, as professoras eram consideradas aptas a realizarem a triagem visual. 
Foto 6 - Atividade pedagógica sobre saúde ocular em uma escola Municipal de Morungaba - SP, 2000.

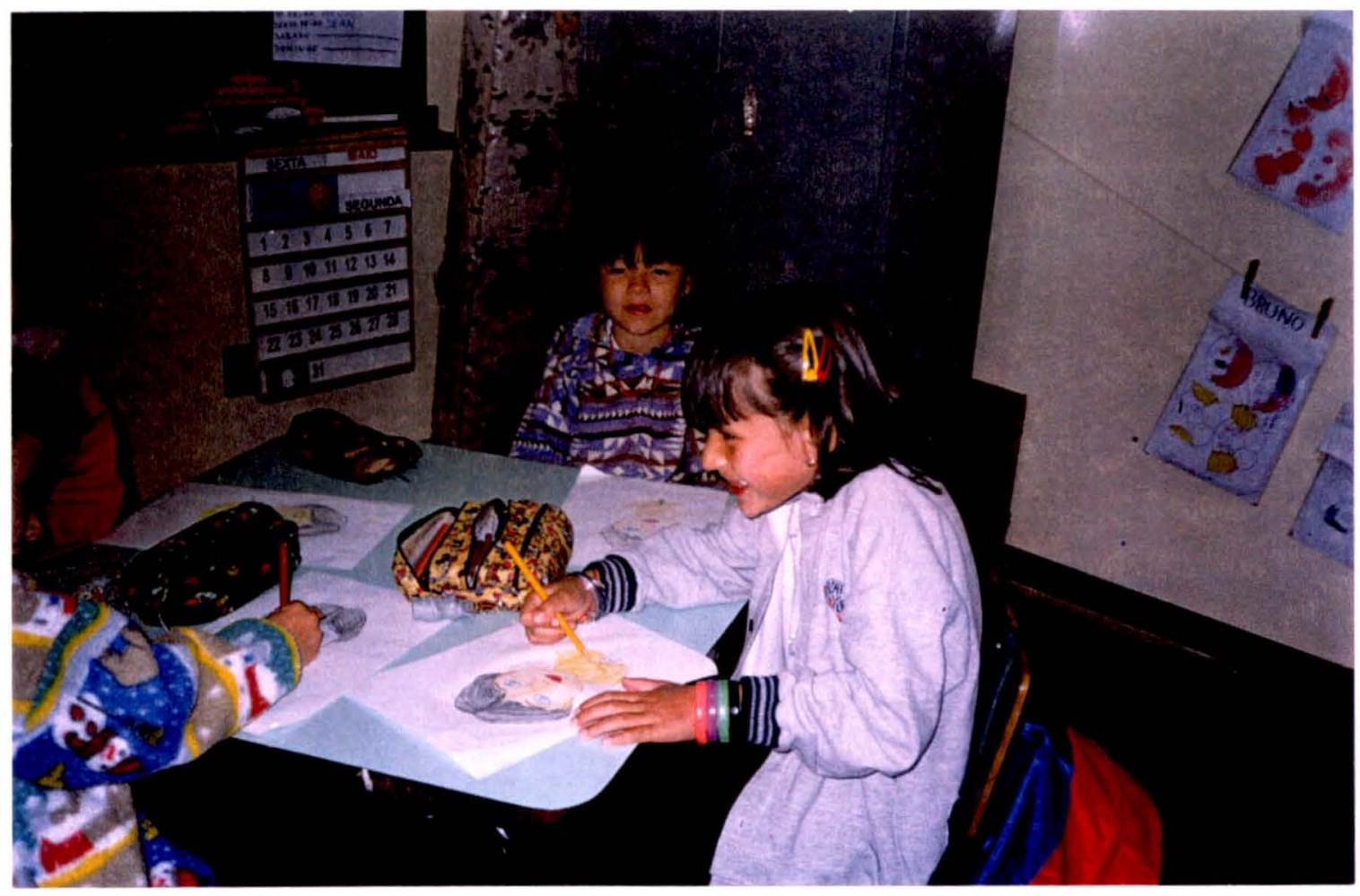

Foto 7 - Atividade pedagógica sobre saúde ocular em uma escola Municipal de Morungaba - SP, 2000.

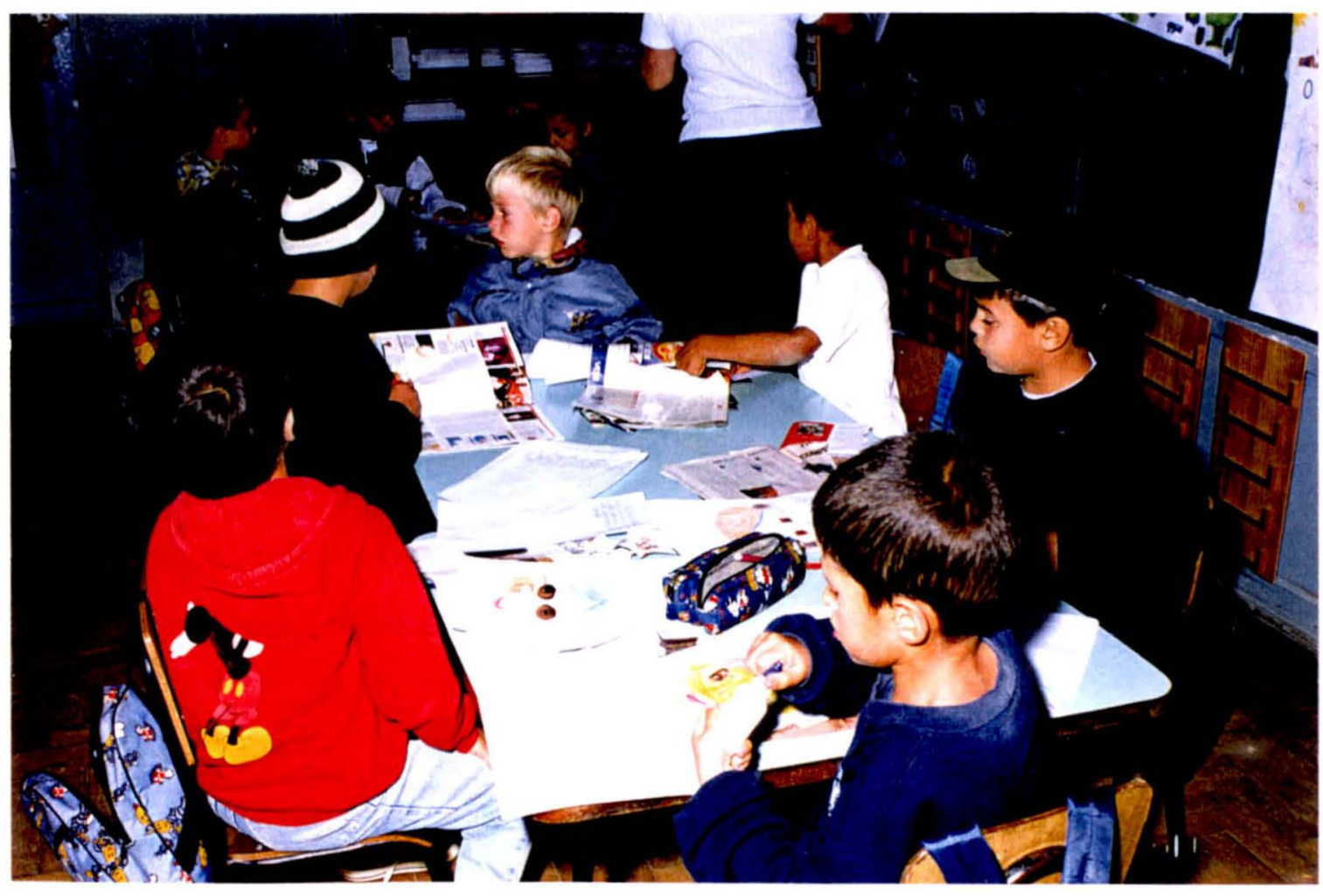


Em um desses dias de visita às Escolas, ao se chegar à EMEI São Benedito, um fato curioso aconteceu na sala do Jardim I: pela manhã, a professora estava reunida com seus alunos, conversando descontraidamente sobre os cuidados que se deve ter com os olhos. quando fez a pergunta (Foto 8):

"Quais os cuidados que devemos ter com os nossos olhinhos?"

Uma criança de 4 para 5 anos respondeu:

"Que deveria tomar cuidado com o 'coce' do cavalo..".

Uma outra respondeu:

"Que temos ter cuidado com 'agúia'.. (agulha)

Sem entender o que queriam dizer, a professora contou que uma pessoa havia ficado cega em Morungaba por causa de um coice de cavalo, - que denota que ela tentou buscar exemplos práticos na comunidade para trabalhar alguns conceitos básicos.

Pode-se perceber, mediante observação, que a maioria dos professores das Escolas - municipais, estaduais e privadas demonstravam domínio do conteúdo e empatia com os alunos, recorrendo a diferentes técnicas pedagógicas e atividades.

Na EMEF Irineu Tobias haviam composto uma música e estavam confeccionando uma cartilha do pré-primário e da primeira série. Pôde-se presenciar um trabalho muito interessante, durante a visita a essa escola: crianças reunidas no pátio, cantando uma musiquinha para a visita, de forma a deixá-la emocionada. Procurava-se incentivar, não apenas as crianças, como também o professor. 
Foto 8 - Crianças da EMEI São Benedito em grupos para discutir sobre a saúde ocular, Morungaba, 2000.

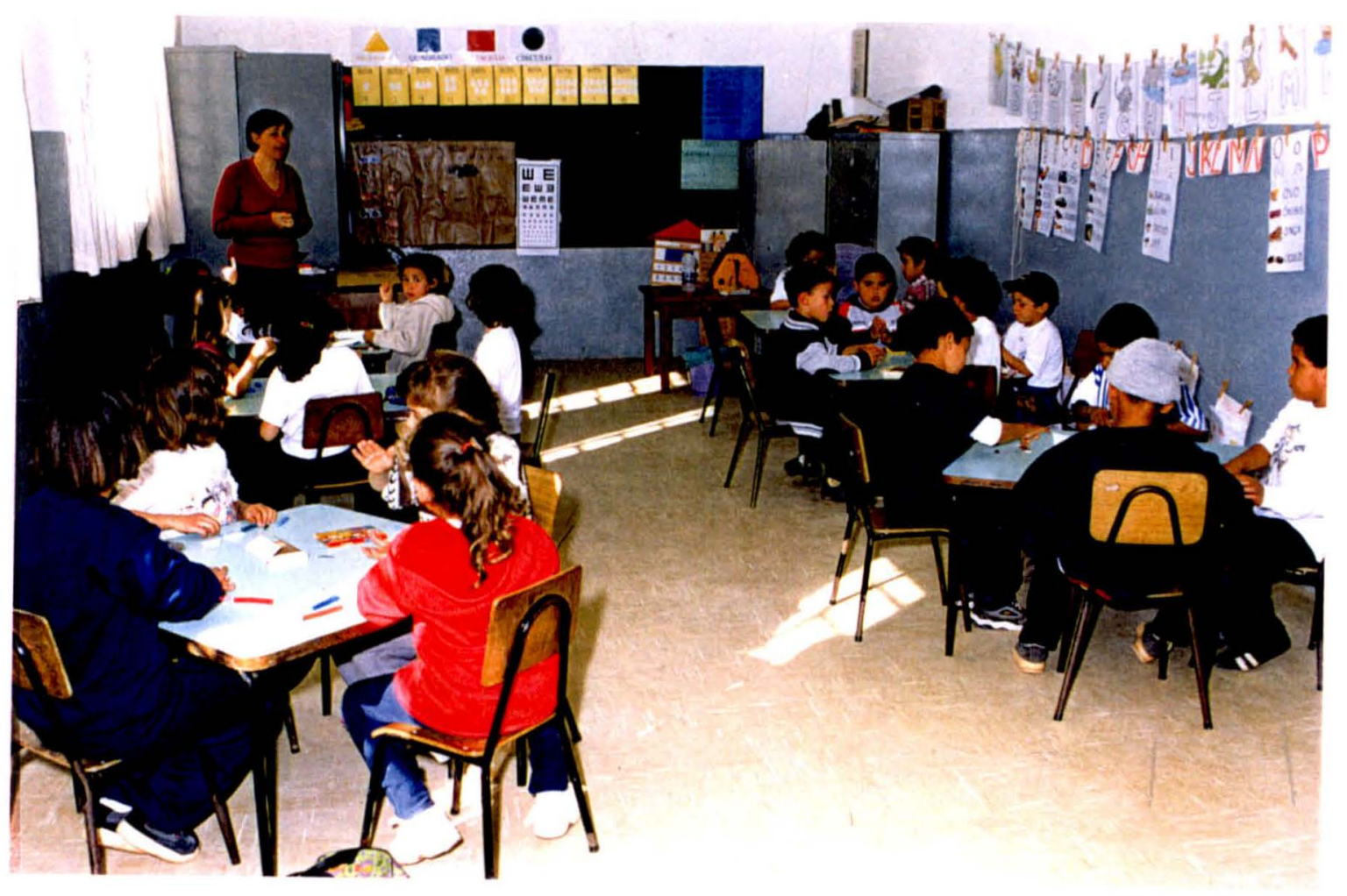


Na escola privada Vidinha Colorida, a apresentação dos trabalhos não foi diferente: fizeram um teatro de fantoches com os personagens propostos, interativo com as crianças de jardim e um teatro com as do pré, em que os protagonistas eram os próprios alunos - um trabalho interessante de se ver. Em todas as atividades realizadas pelos professores, com a colaboração das crianças, eram ressaltados os cuidados com os olhos, quais as atitudes que se devem tomar para preservá-los, o que é teste de visão, para que serve e quem pode fazê-lo (anexo 11).

No Bairro São Benedito, na EMEI, houve, também, a apresentação de uma peça de teatro, seguindo a mesma linha, utilizando como fantoches os personagens criados para o Projeto, diante do que as crianças batiam palmas, riam, não deixando de ser uma atividade diferente.

Assim, as visitas foram acontecendo $e$, com isso, ampliando conhecimentos, não apenas em relação à comunidade escolar, bem como em relação à realidade do cotidiano do professor, das crianças, e de como é grande o potencial de criatividade dos mestres.

No mês de junho, visitou-se, dentre outras, uma das Escolas Estaduais Rurais no Bairro Buenápolis. A pesquisadora ficou impressionada com tanta beleza - o céu azul cercado pelo verde das montanhas, gados à frente e ao longe - e de repente, no meio dessa paisagem, eis que surge uma pequena escolinha solitária, que necessitava de alguns reparos, mas um espaço suficiente para abrigar as crianças, que se apresentavam com roupas simples, relacionando-se umas com as outras, brincando, jogando bola, correndo $e$ rindo. 
Era uma manhã muito fria, a maioria das crianças com agasalhos, alguns pequenos para seu tamanho, grande parte delas estava gripada, mas estavam lá esperando esta pesquisadora. Provavelmente, perguntavam-se: ...mas quem será que vem nos visitar aqui tão longe? Quando a autora deste trabalho se aproximou da estrada de chão de terra, já havia um menininho junto à cerca, que foi correndo avisar os outros que alguém estava chegando. Nesse pequeno paraíso, percebia-se o carinho e respeito das crianças e das pessoas para com a visitante, a maioria delas querendo que a triagem fosse realizada nelas. Algumas com olhares tristes, outras com carinha de travessas e outras, ainda, com certo receio. Diante desse quadro, a pesquisadora ficava a imaginar de que forma poderia ajudá-las e que modificações deveriam ser realizadas naquele lugar; contudo, sua função naquele momento, era outra. Realizada a tarefa, um lanche foi servido pela merendeira $e$, diante da insistência dela e da professora, a pesquisadora dele participou. já que haviam providenciado, especialmente, para sua visita.

- Toma um cafezinho com leite para esquentar?

- Ah! Obrigada mas gostaria apenas puro.

- A senhora vai comer um biscoitinho antes de ir embora, não é?...

- A senhora desculpe-nos a simplicidade mas aqui a gente vive assim.

É importante ressaltar, mais uma vez, que durante o desenvolvimento do Projeto, fazia parte do processo de trabalho, a escuta de experiências de professores e de crianças, criando-se espaços de cooperação para se atingirem os objetivos propostos, valorizando-se a relação professor-aluno na construção deste e de outros projetos. 
A mesma preocupação se fez presente na relação desta pesquisadora com outros grupos participantes.

E assim eram os moradores de Morungaba. A todo momento era relembrado que temos que ser simples para aprender a alcançar nossos objetivos maiores...

Nesse mesmo mês, outras escolas estaduais na zona rural forma visitadas, com o apoio da Diretoria de Educação que cedeu o transporte para sua realização. Essa atenção e percepção eram o que a diferenciava, percebia-se que ela tinha clareza de que estava criando novas oportunidades para o seu Município. E assim foi, o encontro foi em frente à Prefeitura, às sete horas - fazia muito frio, não se conseguia sentir os dedos direito - e em um "Fusca" da década passada, mas bem conservado, ambos forma em busca de novos conhecimentos (Foto 9).

O motorista, Sr. Orlando - simpático e gentil - foi apresentando quase tudo que aparecia e contando as histórias que envolvia, após cada curva, uma casa aqui e a outra não dava para ver, fazendas, olarias, viveiro de cobras, o centro de saúde que estava para ser inaugurado, grandes hortas e muita natureza, a paisagem não podia ser mais bonita. Tinha-se a sensação que se iria tocar o céu. 
Foto 9 - Avaliação da acuidade visual com o método de Snellen na Escola Estadual Rural, Morungaba, 2000.

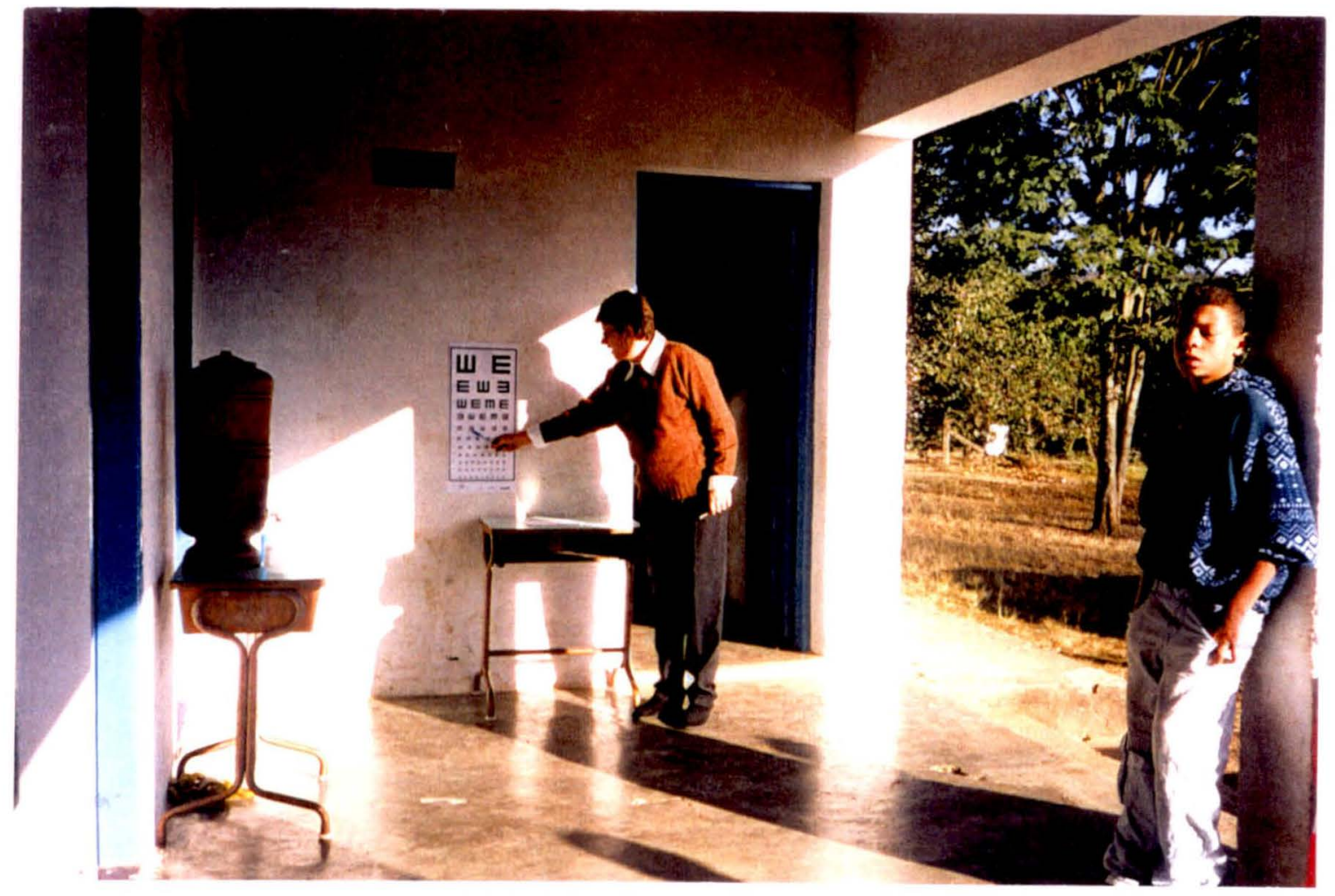


Quando menos se esperava, avistou-se a escola, encravada no meio desse cenário, no bairro do Silva. Nessa, crianças e professores estavam aguardando sorridentes, talvez porque alguém iria visitá-los. Após essa visita, foi-se para outra direção da Cidade, para uma escola Estadual Rural no bairro Gertrudes, em que se conheceram crianças, a triagem foi realizada com duas delas, pelas professoras e pesquisadora, após o que foram dirimidas as dúvidas. Havia uma diferença na organização das Escolas rurais: todas as séries funcionavam juntas na mesma sala. Em relação ao Projeto, em face da decisão da Diretora de Educação, de envolver alunos de até quarta série, ninguém ficou de fora, valendo esclarecer que as escolas que se localizavam na zona rural em Morungaba, eram todas estaduais.

Ao final desse dia, uma sensação de dever quase que cumprido e mais um aprendizado: a simplicidade facilita alcançar alguns objetivos.

As visitas aconteciam em um mesmo dia a diferentes lugares: da Escola privada das freiras às rurais. Chegou a vez da creche, onde se percebeu certa dificuldade de organização dos recursos humanos no local, apresentando defasagem de um período. Auxílio foi solicitado à coordenadora da creche, assistente social, a fim de reorganizá-los em direção à proposta do trabalho, na busca de atingir todas as crianças e não perder o já conquistado, como, por exemplo, as doações dos óculos.

A coordenadora da Creche convocou seu pessoal para uma reunião e expôs sobre a importância do Projeto para as crianças, diante do que solicitou a colaboração dos presentes, de forma a trabalhar os conteúdos de saúde ocular em suas atividades com elas. Foi feito um projetinho para 
a creche, que foi sendo desenvolvido paulatinamente, sem maiores envolvimentos.

As crianças da creche integravam famílias que, aparentemente, enfrentavam problemas econômicos $e$ as mães trabalhavam fora, deixando seus filhos passarem o dia na creche. Eram também crianças pequenas, que necessitavam de atenção e cuidados específicos, aumentando a responsabilidade de quem delas cuidava.

Mesmo assim, foi possível envolver o pessoal da Creche no processo de trabalho, que desenvolveu atividades pedagógicas sobre saúde ocular com as crianças, reinventou uma música, aplicou os testes e participou da exposição na Casa da Cultura.

O Projeto estava definido e em franco desenvolvimento na Educação.

A Diretora da Educação decidiu, após consulta às coordenadoras pedagógicas e a esta pesquisadora, registrar e divulgar as atividades dos alunos, professores e monitoras de creche, por meio de uma exposição dos trabalhos que as crianças, junto com os professores, fossem produzindo sobre a saúde ocular, em um espaço público, para que os pais tivessem acesso, valorizando a produção das crianças e o trabalho desenvolvido pelos professores.

As idéias dos professores implicaram diferentes técnicas pedagógicas, na tentativa de transmitir algum conteúdo de saúde ocular para seus alunos, como foi referido em parágrafos anteriores: lindos cartazes, trabalhos em massinha, sucatas, músicas, teatro, envolvendo os próprios professores e alunos (Foto 10). 
Foto 10 - Atividade pedagógica sobre saúde ocular com as crianças da Creche Municipal de Morungaba, 2000.

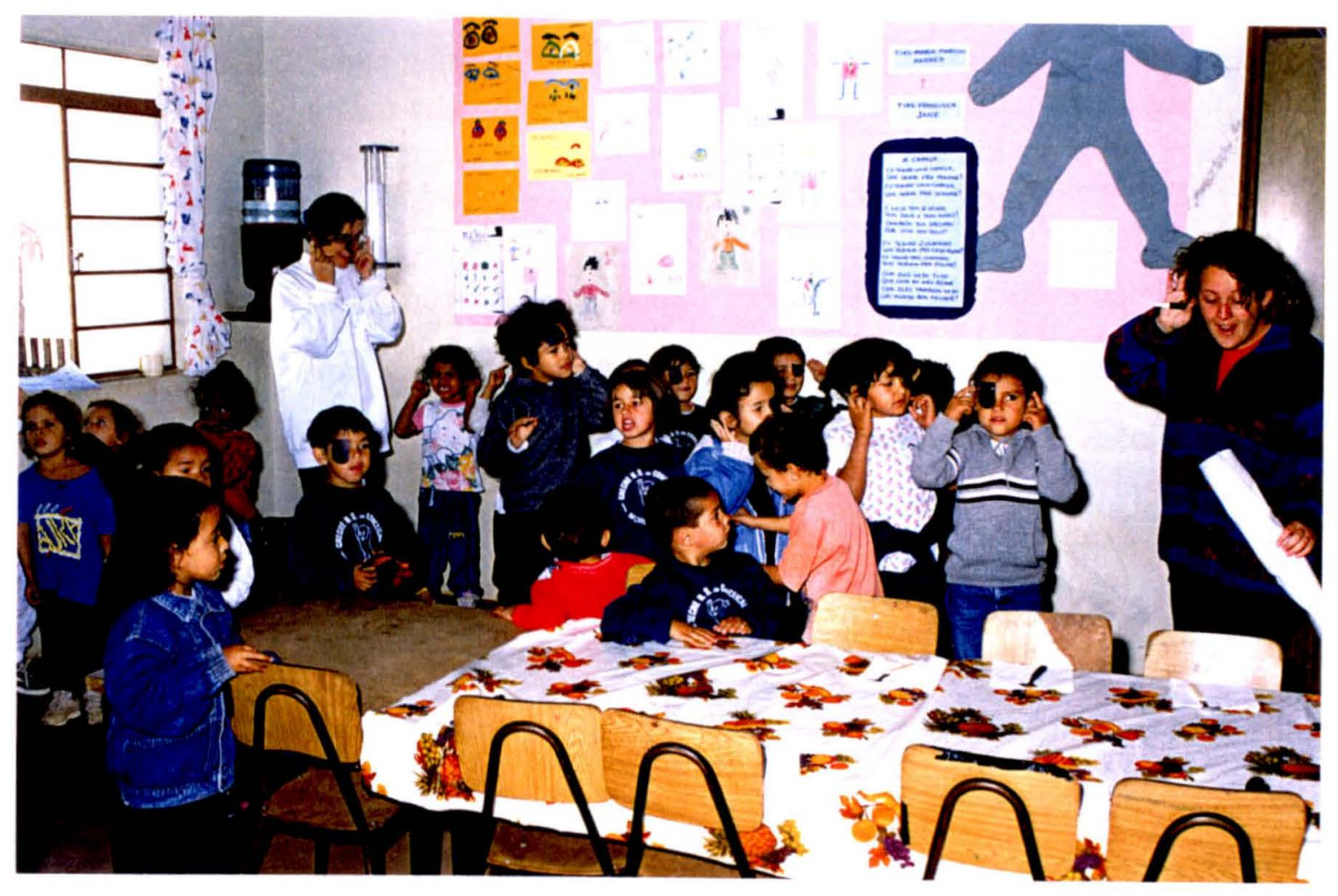


Quando iniciaram a aplicação dos testes visuais, procederam aos retestes naquelas crianças em que percebiam alguma dificuldade e encaminhavam as confirmadas para o centro de saúde, aguardando os resultados do médico: se as mães não levassem, após um certo tempo, encaminhavam uma cartinha e conversavam com elas sobre a importância de levarem seus filhos.

A primeira criança a chegar com óculos na Escola, foi motivo de orgulho para todos que haviam contribuído para que isso acontecesse.

Uma professora relatou:

"Essa criança não estava bem nas atividades pedagógicas, sempre foi muito apática mas, depois dos óculos mudou muita coisa, chego a me emocionar. O primeiro dia em que colocou os óculos me disse que não sabia como as árvores eram coloridas e bonitas"...

E o Projeto foi tomando forma, todas as Escolas do Município e a creche municipal, que atendiam crianças de 0 a 7 anos, foram visitadas individualmente, foi-se conhecendo cada professor e sua realidade escola e seus alunos, cada vez mais aumentava a paixão por aquele lugar $e$ por aquelas crianças que, ao avistarem a pesquisadora, já anunciavam de longe umas para as outras, correndo em sua direção, para escutarem um simples Oiiiiil e uma brincadeirinha, que, para os adultos, às vezes, soa banal mas, para elas, era motivo de risadas, expressão do ser criança...

Quanta responsabilidade quanto a atitudes, diante de tanta pureza, de tantas necessidades perceptíveis a olho nu, que não só a questão da saúde ocular...

Tinha-se vontade de pertencer à comunidade, não apenas como visitante, mas como moradora. 
O processo de trabalho na área da Educação foi sendo construído lentamente em bases sólidas, criando raízes com perspectivas outras que não só o processo educacional.

Era como se se tivesse plantado uma árvore no quintal da Prefeitura, na sala da Educação, e várias pessoas se lembrassem de regá-la e podá-la quando necessário.

A exposição: a exposição de trabalhos das crianças teve, como sede, a Casa da Cultura de Morungaba, organizada por professores, coordenadoras pedagógicas e Diretora de Educação, e ficou aberta para o público durante uma semana, em junho de 2000. Foi muito estimulante o envolvimento dos professores, trabalhando como se fosse a construção de um prédio, todos em conjunto, cada escola com espaço para as suas produções, uma mais bela do que a outra, mensagens das crianças em relação à saúde ocular (Foto 11 e Foto 12).

Preciso levar na Casa da Cultura os trabalhos dos meus alunos, comentava uma professora para outra.

Nós precisamos deixar organizada a sala, como poderíamos fazer? Será que vão caber todos os trabalhos?

A exposição, segundo a leitura desta autora, causou um impacto, à medida que o espaço criado pelos atores sociais da área da Educação, a Casa da Cultura, localiza-se em um ponto estratégico: a entrada da cidade - mudando, momentaneamente, o jeito da cidade, tendo, logo à sua entrada, marcas de quem forma opinião das pessoas - as professoras e de quem seria o futuro da Cidade - as crianças. 
Foto 11 - Exposição dos trabalhos pedagógicos realizados pelos alunos das escolas Estaduais, Municipais, Privadas e Creche Municipal de Morungaba, 2000.

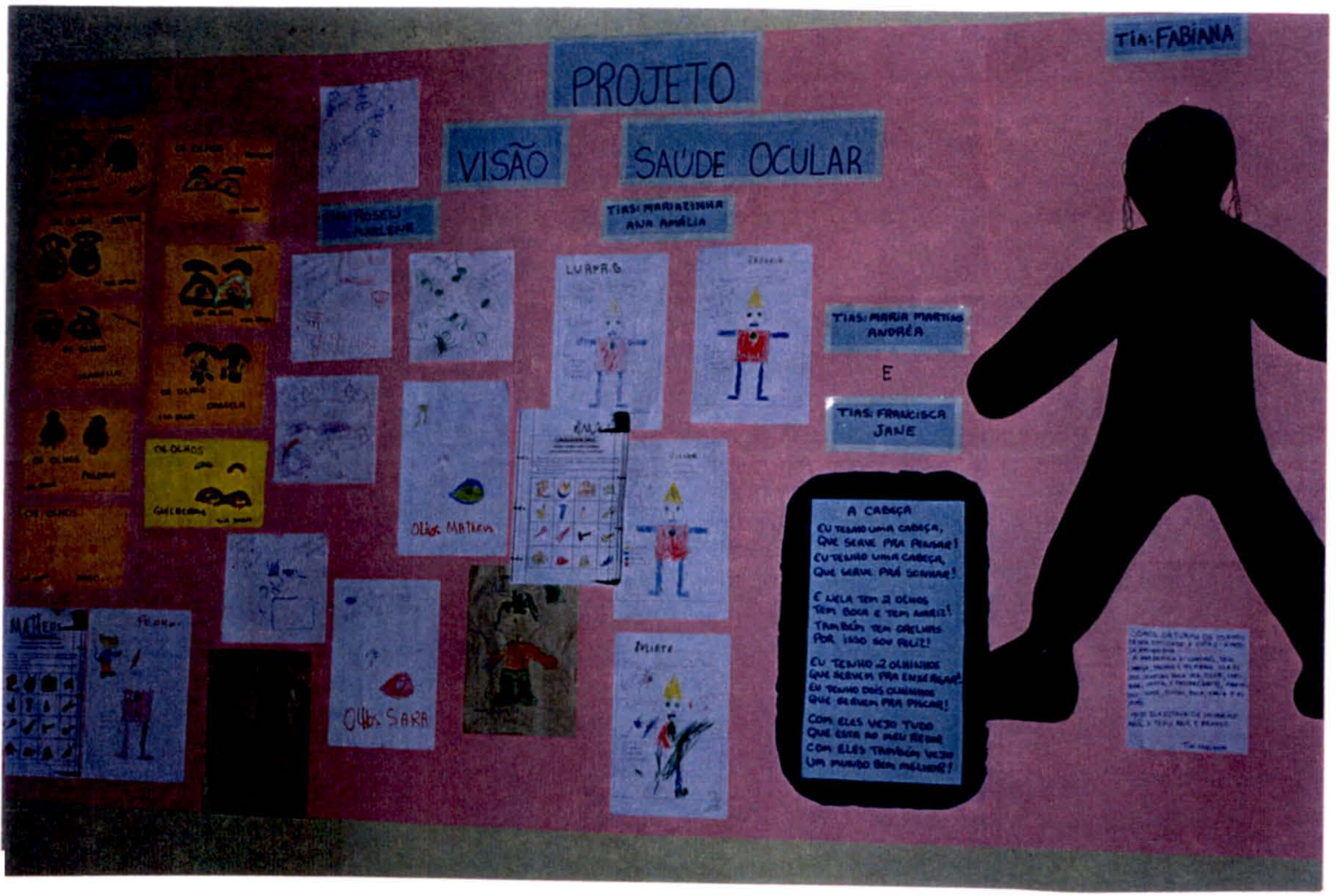

Foto 12 - Trabalho pedagógico sobre saúde ocular com as crianças da Creche Municipal de Morungaba, 2000.

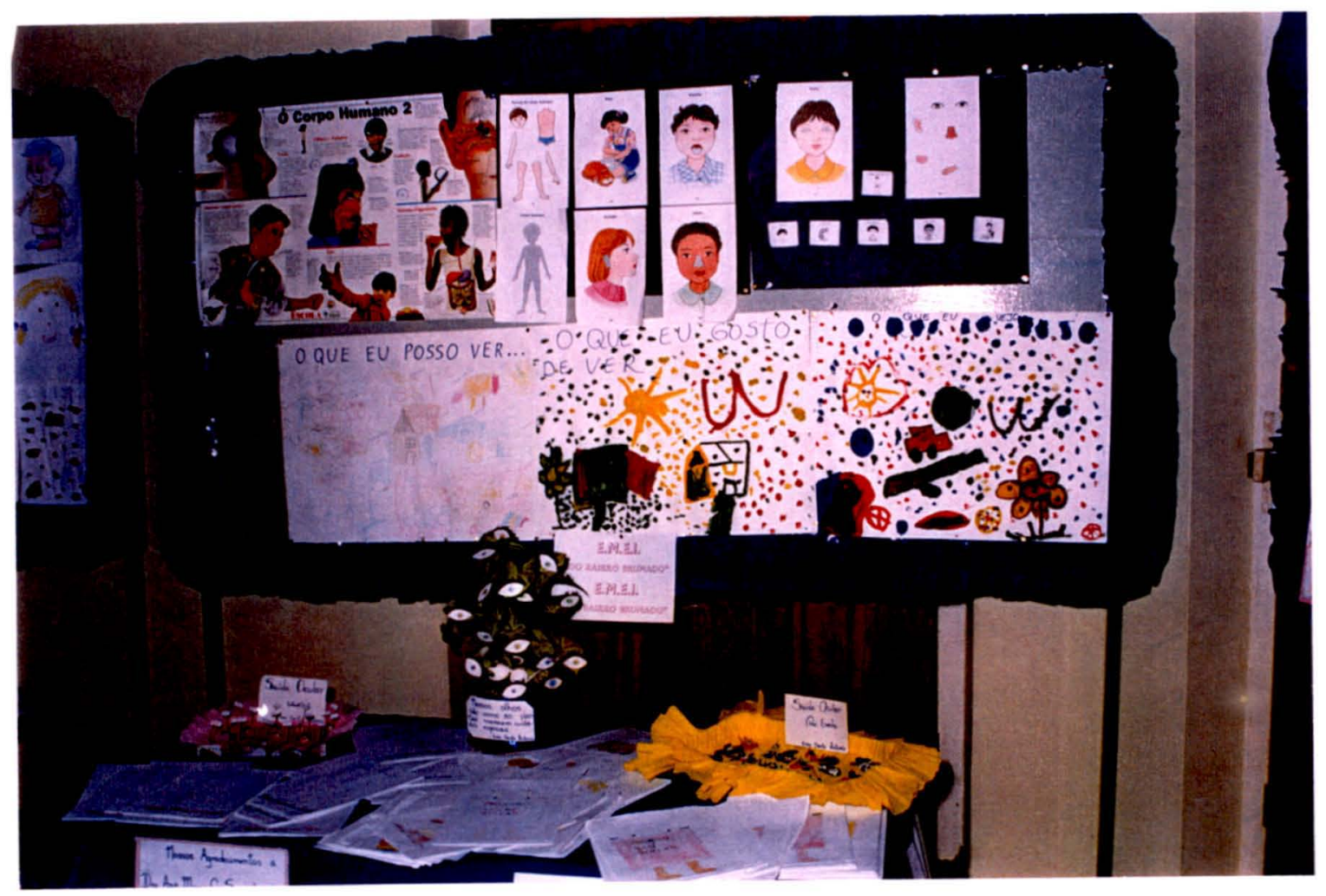


A exposição foi solenemente aberta pela Prefeita de Morungaba, com um discurso que expressava o significado do Projeto para a Cidade (anexo 14).

Durante a exposição dos trabalhos, os visitantes recebiam um material - "folder"(anexo 15), com historinhas em quadrinhos, abordando os cuidados com os olhos e o que fazer para protegê-los, criado pelo grupo de trabalho da Educação, com o apoio de sua Diretoria, que arcou integralmente com sua confecção e reprodução.

Assim, o trabalho foi se desenvolvendo na Educação, segundo a dinâmica que compreendeu:

- Treinamentos de manhã e à tarde, conforme as necessidades dos grupos, com carga horária de 8 horas para a parte teórica, e uma hora, por escola, para acompanhamento da parte prática (Foto 13 e Foto 14):

- Reuniões periódicas com o grupo de professores e monitoras de creche para acompanhar a execução, sanar possíveis dificuldades e ressaltar os sucessos obtidos:

- Reunião com o corpo docente de cada escola para comunicar o que iria acontecer e aferir/reforçar o conhecimento básico necessário para executar o Projeto:

- Reunião com pais de crianças:

- Trabalho em sala de aula, para abordagem de conhecimentos básicos de saúde ocular junto às crianças, recorrendo a diferentes técnicas pedagógicas:

- Triagem de sinais e sintomas de problemas visuais; 
- Realização da triagem visual nas crianças, mediante aplicação dos diferentes testes definidos (Foto 14);

- Reteste em crianças que tivessem apresentado alguma dificuldade na triagem:

- Encaminhamentos para o Centro de Saúde das crianças que apresentaram dificuldades após o reteste;

- Nova triagem visual nessas crianças, pelo pessoal da saúde:

- Encaminhamento para o oftalmologista das crianças em que realmente se confirmaram dificuldades visuais:

- Consulta oftalmológica:

- Encaminhamento para doação de óculos, desde que constatada a necessidade de uso:

- Referência de crianças para serviços de maior complexidade tecnológica em situações que a requeressem.

Em reunião com a Diretora da Educação, no início do segundo semestre de 2000, foi-lhe indagado sobre a possível existência de Lei, no Município, sobre a obrigatoriedade da avaliação da acuidade visual nas escolas, ao que disse desconhecer, porém iria pesquisar a respeito.

Em outra reunião, marcada para outro fim (divulgação televisiva do Projeto, e sobre a qual se fala mais adiante), a Diretora estava de posse de uma Lei de 1998, que apresentava como obrigação das Escolas a avaliação da acuidade visual e auditiva de crianças de 7 a 14 anos. A pesquisadora foi consultada sobre o teor da Lei e possíveis alterações, que depois iria analisar e encaminhar para o setor competente para dar andamento nos procedimentos para as possiveis alterações. 
Foto 13 - Treinamento prático na Escola Privada de Morungaba, 2000.

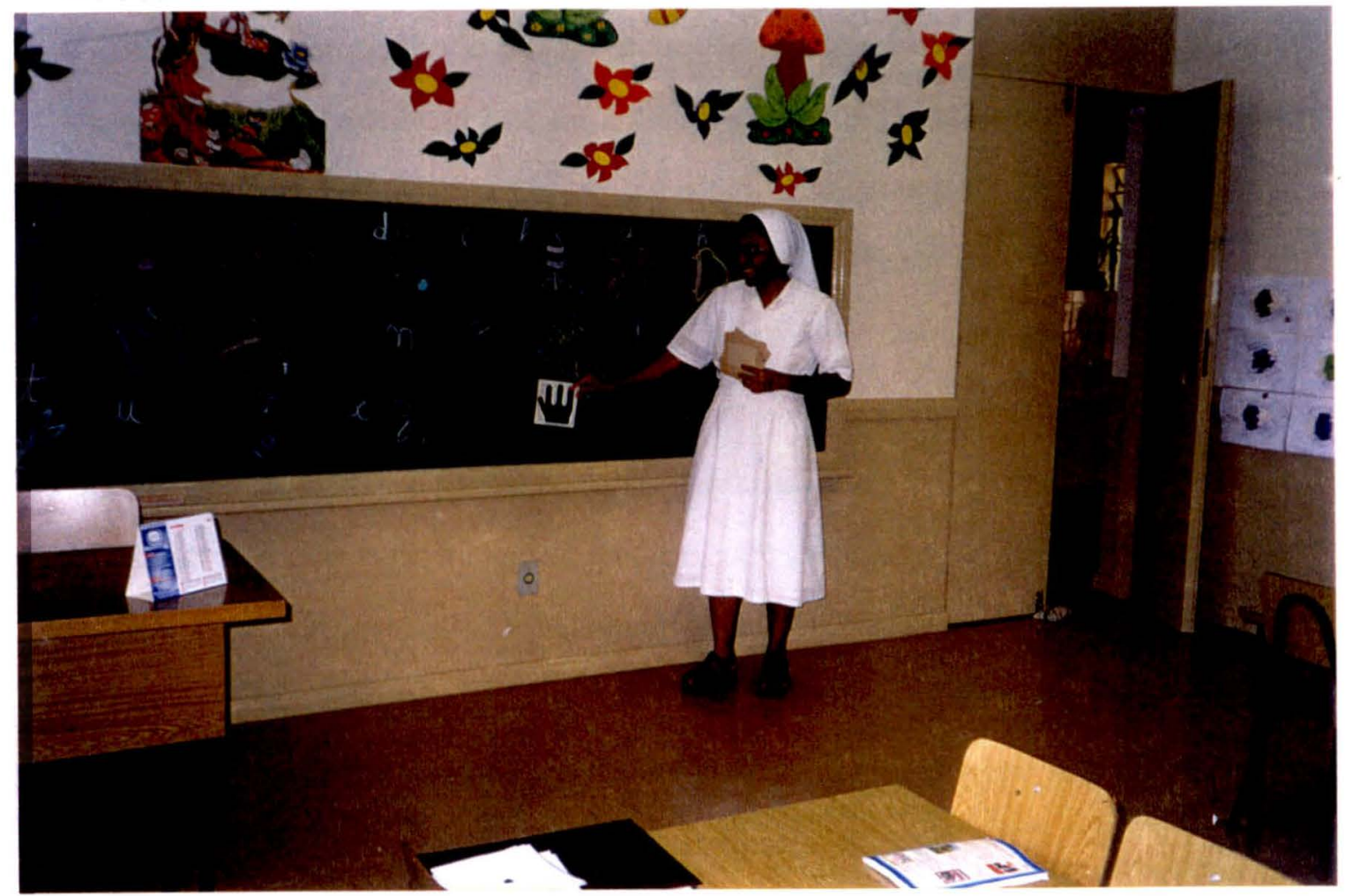

Foto 14 - Aplicação do teste de angular " mãozinha", Morungaba, 2000.

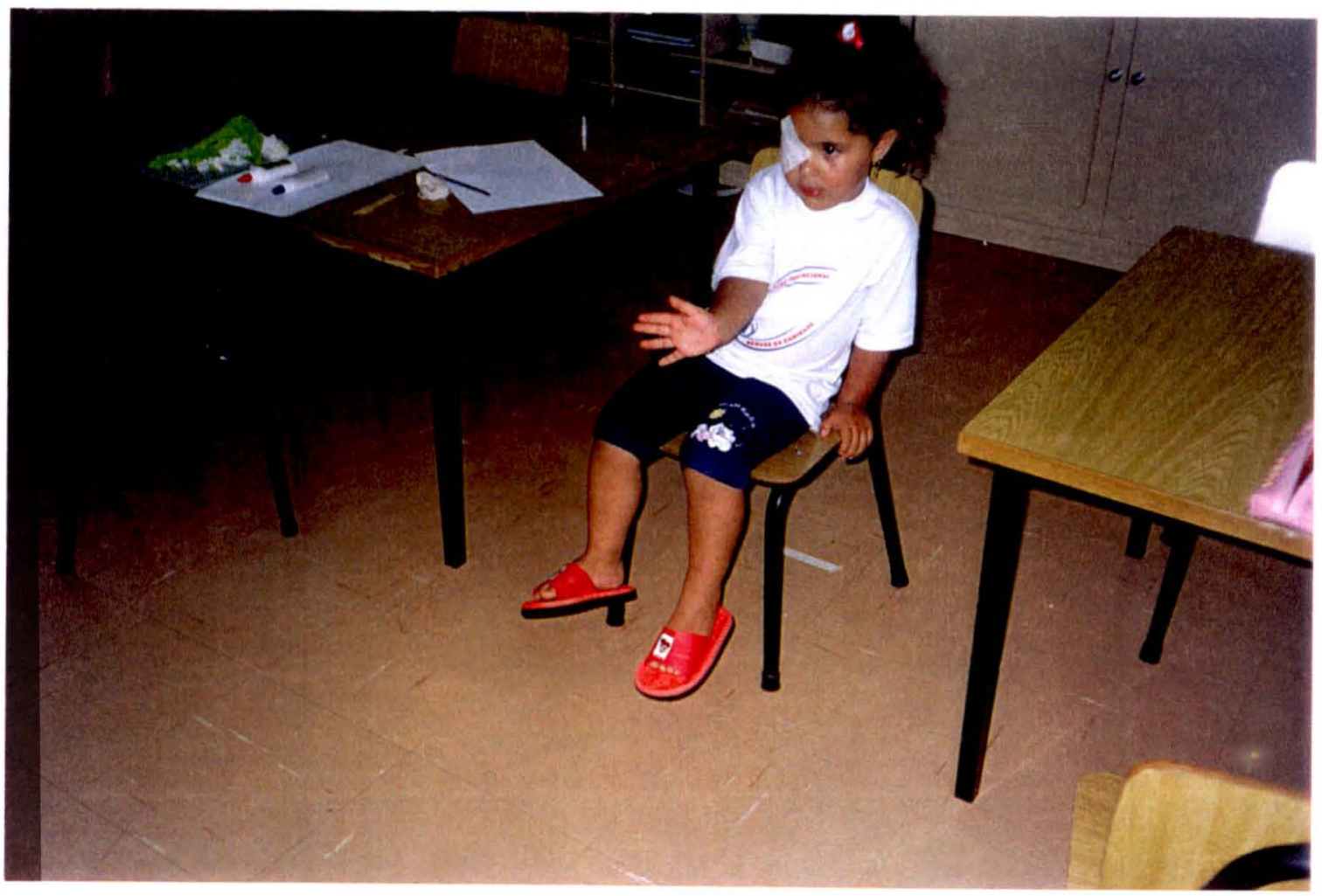


Uns dias depois, durante almoço com a Diretora da Educação, no único restaurante do centro da Cidade que servia uma comidinha caseira deliciosa, acompanhada de uma advogada da Prefeitura, foi-lhe exposta a intenção de recriar a Lei do Município sobre as ações de saúde ocular, com mais detalhamentos para esta área. A advogada referiu que seria possível viabilizar a idéia, mediante envio de uma proposta para a Câmara de Vereadores para avaliação e devidos encaminhamentos. A partir daí, a Diretora providenciou os reparos necessários, considerando as sugestões apresentadas pela pesquisadora, discutiu com o Diretor de Esporte e Turismo e com a própria advogada e, depois, com o advogado responsável pela redação das leis a terem vigência no Município, para apreciação sobre sua adequação. Direcionou e articulou os encaminhamentos necessários para o envio do documento reformulado para a Câmara dos Vereadores, que o aprovou em dezembro de 2000.

Essa atitude, na leitura desta investigadora, foi movida pelo desejo de garantir a continuidade das atividades de saúde ocular, envolvendo os setores de Educação e de Saúde, para os próximos anos, independente da mudança político-administrativa, dado que o mandato da Prefeita, em exercício, encerrava-se em 31 de dezembro de 2000. Com isso, o Município passou a contar com uma Lei que tornou viável a continuidade de sua execução, ora desencadeada por este Projeto (anexo 16).

Esse foi mais um ganho para a Cidade, quiçás dos mais importantes, que foi obtido em decorrência do Projeto, graças à articulação política da Diretora de Educação. O setor da Educação de Morungaba havia tomando para si o Projeto, como diria BORDENAVE (1994). 
Abordando, agora, a questão da divulgação televisiva, mencionada um pouco antes, sentiu-se necessidade de maior divulgação do Projeto, decidindo-se por enviar uma solicitação, em que se resumia o trabalho em desenvolvimento, para o setor de jornalismo da Rede Globo/local.

A demonstração imediata de interesse da emissora pelo assunto foi - agendamento de uma visita ao Município pela equipe de jornalismo da Emissora para uma reportagem sobre o Projeto.

O dia foi marcado, após consulta à Prefeita e à Diretora de Educação, ficando definido que a reportagem ficaria centrada nas escolas, com os próprios professores e crianças, no centro de saúde e na comunidade e que, em cada local, haveria o registro de algum momento do Projeto. Todas as escolas e o Centro de Saúde receberam o comunicado, assim como o Coordenador da Pastoral da Criança.

Criou-se um clima de contentamento e ansiedade entre as pessoas, dentre elas, a pesquisadora, por entender que era uma forma de valorizar o trabalho dos atores sociais locais e de divulgar o Projeto.

No dia marcado, estavam todos a postos: as professoras e monitoras de creche com atividades preparadas, referentes ao Projeto de Promoção de Saúde Ocular e Prevenção Precoce de problemas Visuais, o pessoal do Centro de Saúde e da Pastoral da Criança aguardando a visita. Aí aconteceu o inesperado: a equipe da rede Globo avisou que não iria conseguir deslocar-se para Morungaba, porque tinha que fazer a cobertura de fatos que haviam ocorrido naquele momento entre eles, uma rebelião de presos na região e um incidente com um botijão de gás que havia explodido no centro de Campinas $e$, com isso, adiando para 
outro dia que, por sinal, também teve que ser remarcado, até que, finalmente, concretizou-se em setembro de 2000.

Professoras e crianças, muito envergonhadas, participaram da reportagem, assim como o pessoal do Centro de saúde e usuários, e, por fim, a pesquisadora concedeu uma entrevista rápida, atendendo à solicitação da repórter, expondo, em linhas gerais, o desenvolvimento do Projeto.

Uma delas (participantes) dizia:

"Acho que não vou conseguir falar nada, estou nervosa".

Procurou-se acalmá-la, dizendo-lhe que não havia razão para ficar nervosa, uma vez que eram elas que estavam desenvolvendo o trabalho.

Foi mais uma experiência diferente vivida no Município.

E o tempo foi passando, as relações estavam estabelecidas, o profissionalismo, o respeito e carinho permeavam o trabalho.

Uma outra forma de reconhecimento, e que foi colocada para os participantes da área da educação apenas na última etapa do trabalho, foi a notícia de que os professores e monitoras de creche (bem como os participantes dos outros setores da sociedade) iriam receber um certificado de participação no Projeto, fornecida pela Faculdade de Saúde Pública/USP, com a carga horária freqüentada, assinado pela pesquisadora e por um docente do Departamento Saúde Materno-Infantil da FSP/USP e por um representante da Prefeitura local.

No final do ano de 2000, no início de dezembro, a pesquisadora recebeu, em sua residência, uma carta enviada pela Prefeitura de Morungaba. Quando a abriu, seu coração encheu-se de emoção: era o 
convite para a formatura de pré-primário das crianças das Escolas Municipais, participantes do Projeto (anexo 18).

A pesquisadora foi acompanhada de sua família ao evento, porque seria à noite e não gostaria de dirigir nesse horário. Chegaram um pouco atrasados, mas ao ser vista, de imediato foi solicitada para que ocupasse uma das cadeiras reservadas a convidados "ilustres". Ao observar aquelas crianças, cerca de 200, de beca e sorridentes, naquele dia, o centro das atenções, a pesquisadora foi tomada pela emoção.

Sentiu naquele momento seus pensamentos divagarem em relação ao futuro delas e, ao direcionar os seus olhos para as crianças, vislumbrou uma delas de óculos $e$, de repente, sentiu seus olhos se encherem de lágrima, ao perceber que o pouco que havía sido feito em seu benefício, estava modificando a sua relação com a vida. Foi quando, sem se aperceber, foi convidada a receber uma homenagem das professoras e alunos, com agradecimentos formais ao Projeto e à sua pessoa, além de um lindo ramalhete de flores que, de certa forma, caracterizavam bem os campos do Município. Naquele dia, sentiu orgulho de todos que alí estavam e percebeu quantas pessoas conhecia em Morungaba, quanto carinho recebia... era uma pena, mas percebia que sua permanência na Cidade estava chegando ao fim...

Concomitante a essa experiência que estava sendo desenvolvida na área da Educação, a preocupação da autora estava, também, voltada para - espaço de trabalho na área da saúde, que estava em fase de organização para iniciar o treinamento. 
Muito esforço foi despendido para que minimamente se conseguisse reunir o pessoal da Saúde para uma apresentação do Projeto e dar início ao programa de treinamento.

Finalmente, em maio de 2000, foi realizado o treinamento com o pessoal da saúde, no período das 10:30 hs às 13:00, para o qual tinham sido convidados o pessoal da área de enfermagem e da administração das duas unidades de saúde. Dentre 13 convidados, apenas 8 participaram, todos eles do período da manhã. O grupo se mostrou bastante interessado e participativo, elaborando pensamentos progressistas e formulando definições importantes como a de promoção da saúde:

"Sendo algo que vem antes da prevenção, para promover tem que existir saneamento, lazer, bons salários, emprego, moradia".

O desempenho e o interesse dos participantes foram surpreendentes.

Na outra unidade de saúde, localizada no bairro do Brumado, funcionava o programa de saúde mental e pediatria, mas as atividades gerais da saúde eram direcionadas para o centro de saúde de porte maior.

Foi marcado um outro encontro, em data pré-estabelecida pelo grupo. Neste, o enfermeiro responsável não estava na hora marcada e apenas dois funcionários haviam comparecido. Ficou-se aguardando 0 enfermeiro para iniciar $e$, assim que chegou, comentou que havia algumas dificuldades, e ele, responsável apenas pelo pessoal da enfermagem, não queria se envolver com problemas administrativos (Foto 15 e Foto 16 ). 
Foto 15 - Técnica de sensibilização utilizada nos treinamentos de ações básicas de saúde ocular, Morungaba, 2000.

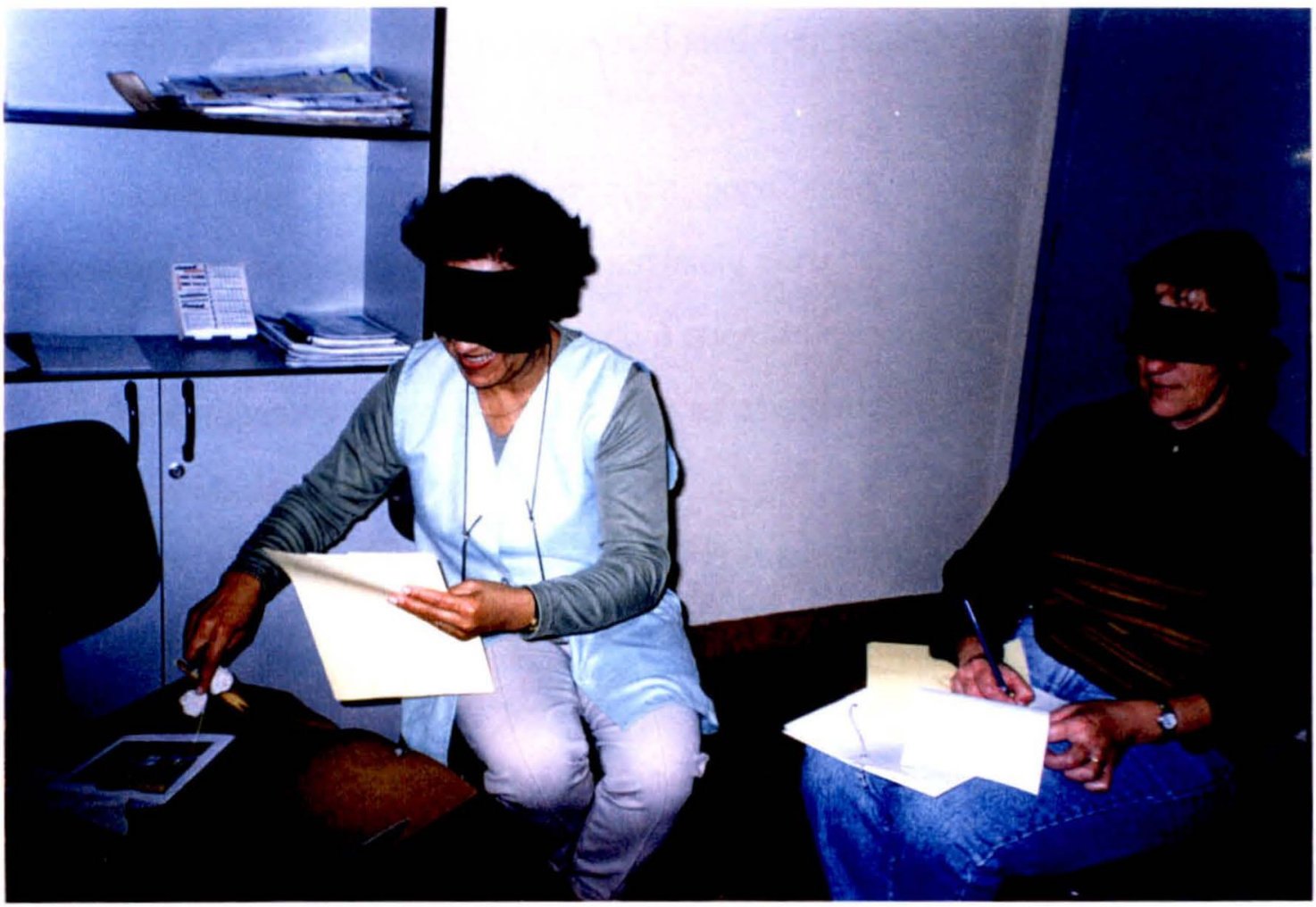

Foto 16 - Treinamento sobre ações básicas de saúde ocular para pessoal para saúde, Morungaba, 2000.

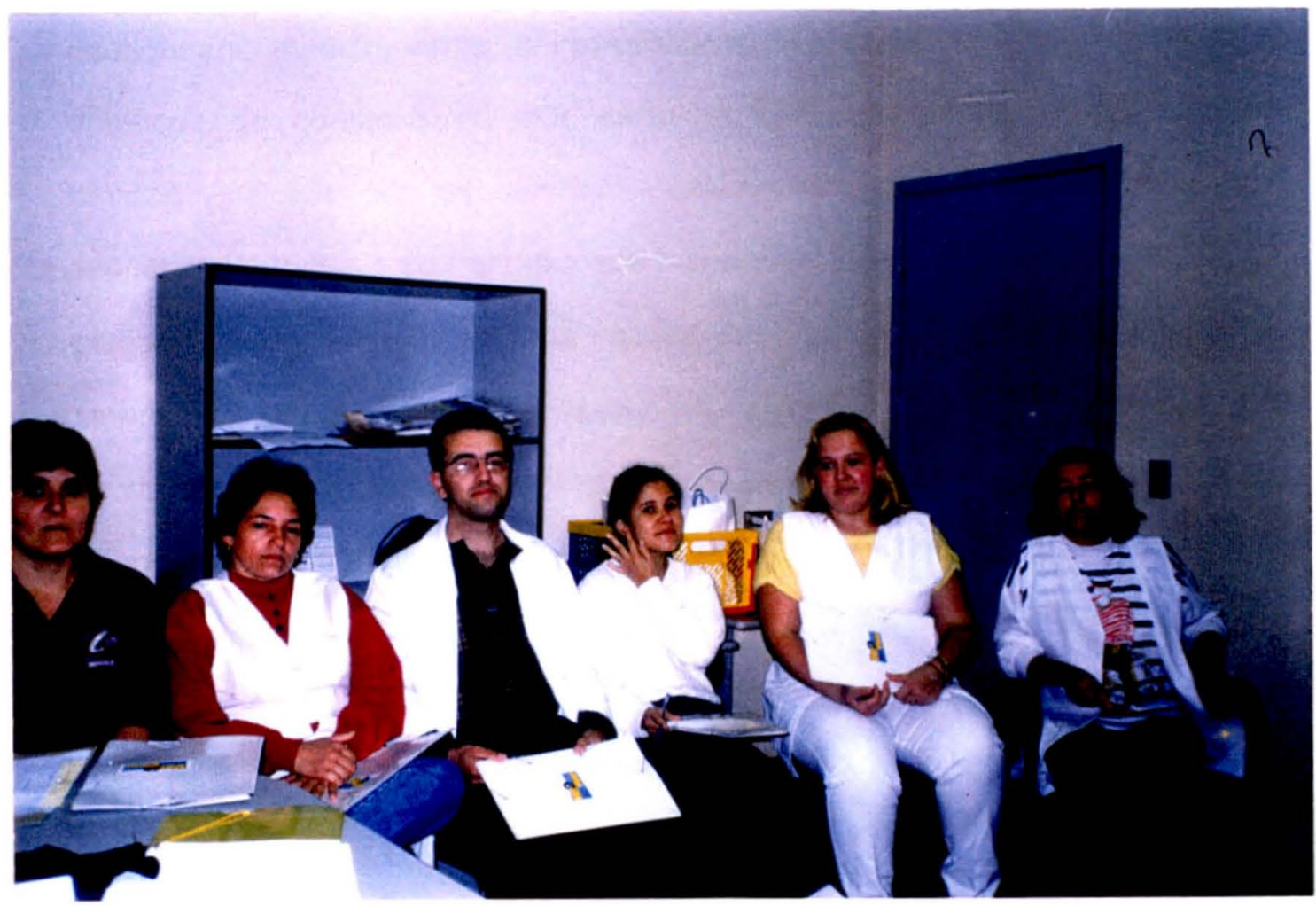


No encontro seguinte, o número de pessoas participantes do treinamento da saúde ficou reduzido a duas pessoas. Contava-se com a presença do enfermeiro responsável mas, por razões pessoais alegadas, não pôde participar.

Uma das hipóteses levantadas para essa baixa frequiência aos encontros, ou mesmo, a falta de estímulo para com o desenvolvimento do Projeto, pareceu estar relacionado à questão gerencial - falta de visão e de comando mais firme, para integrar as atividades do Projeto, dentro da sua realidade de trabalho.

Em um dos dia agendados para treinamento, segundo combinação entre as próprias pessoas da saúde, não apareceu ninguém.

Esse fato não foi motivo para sua desistência, sabia que os participantes iriam aparecer: era uma questão de saber esperar, talvez, aparecessem voluntariamente ou de forma provocada, tomando de empréstimo as palavras de BORDENAVE (1994).

$\mathrm{Na}$ Saúde, contou-se com três pessoas, todas auxiliares de enfermagem, que se envolveram e de certa maneira, esforçaram-se para realizarem, minimamente, a retestagem de escolares e a triagem das crianças da comunidade, que estavam fora da escola: apesar disso, percebia-se que não se sentiam responsáveis pelo Projeto. Deixavam transparecer que o faziam, porque havia sido sugerido e pedido para que participassem; tinham as suas razões para se sentirem assim, pois elas tinham que fazer o que caberia ao Centro de Saúde realizar, uma vez que as tarefas não tinham sido distribuídas, envolvendo outras pessoas, como chegaram a comentar: 
"Tenho que fazer quase todas as atividades da área de enfermagem: curativos, papanicolau, pesar $e$ medir $e$ ainda atender is vezes a recepção..."

"As tarefas, aqui, não são definidas..."

"Nós queríamos fazer os testes nas crianças mas, não dá tempo..."

"São coisas que magoam, porque a saúde não pode esperar essa época política acabar para começar o tratamento, pode ser tarde..."

Participaram do acompanhamento do aprendizado na unidade de saúde, em que foram triados bebês, crianças de três anos e de sete de idade. Mostraram-se contentes ao conseguirem realizar a triagem em crianças menores, o que, inicialmente, achavam que não iriam conseguir.

"Ana, acho que é muito difícil, vou me atrapalhar toda..".

Sempre se fazia questão de enfatizar, tanto para o pessoal da Saúde, como para o da Educação, que era questão de treino explicarem para as crianças o que iria acontecer e também treiná-las, para responderem aos testes visuais. E se ressaltava que o custo da ação desenvolvida por elas seria muito mais baixo do que o custo de se manter uma criança com problema visual irreversível.

Realizaram as atividades, de acordo com a dinâmica da unidade de saúde, apesar de alguns contrapontos: criou-se um livro de registro de crianças triadas, que deveria ser preenchido à cada criança (caso novo) de 0 a 7 anos, que chegava à unidade para triagem visual (Foto 17); prepararam a sala para realização da triagem; afixaram cartazes, confeccionados por crianças das escolas, nas paredes do centro de saúde: retestaram as crianças das escolas e de creche, encaminhadas por 
professores; triaram algumas crianças na comunidade quando iam para visita domiciliar; encaminharam e marcaram consulta com 0 oftalmologista; mantiveram um canal de comunicação entre o oftalmologista e outros integrantes do Projeto; mediram a distância das pupilas das crianças para avaliar se os óculos doados pela fábrica eram adequados para cada caso; responsabilizaram-se por entregar uma cópia da receita prescrita pelo oftalmologista para a fábrica de óculos, desta feita, pegaram a armação, entregando-a ao paciente; orientaram mães para se dirigirem à ótica, após a posse da armação; chamaram, por meio de ligações telefônicas, crianças faltosas à consulta oftalmológica; enfim, foram inúmeros e diferentes procedimentos que coube ao Centro de Saúde realizar, dentro do Projeto.

A resposta do pessoal da Saúde ao chamamento do Projeto - baixa frequiencia, pequeno envolvimento - fez a autora deste trabalho a refletir sobre as possiveis causas, contrariamente ao que sucedera com o pessoal da Educação, em que a grande maioria dos professores se mobilizou e se articulou prontamente, envolvendo-se no processo em todos os seus passos. 
Foto 17 - Teste de acuidade visual com o método de Snellen realizado no Centro de Saúde de Morungaba, 2000.

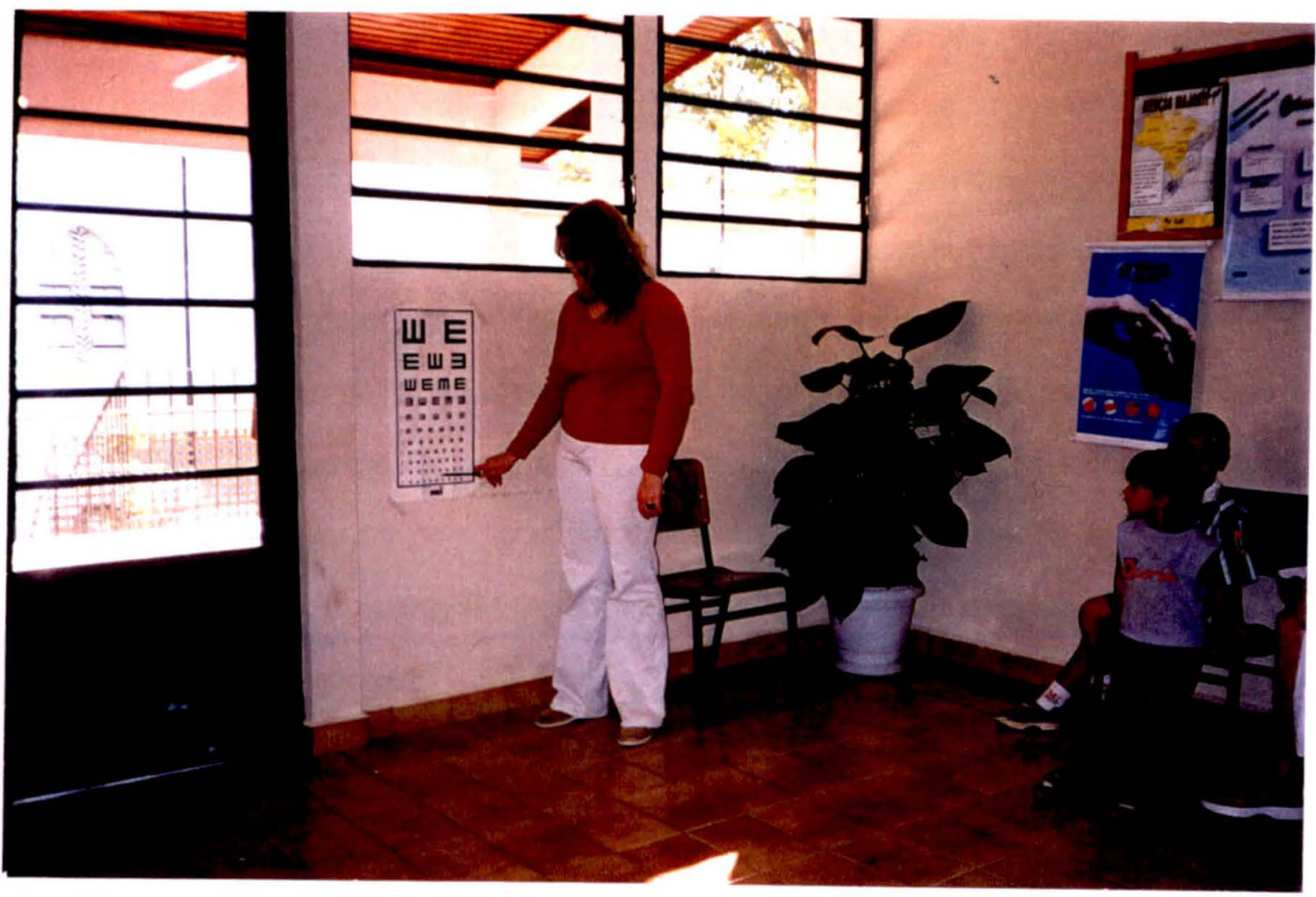


Ao se analisar a questão da participação dos diferentes setores, em Morungaba, uma hipótese que se apresenta para explicar a maior ou menor participação, refere-se à questão gerencial, mais concretamente, ao posicionamento de quem está na coordenação do setor diante do Projeto e à qualidade de sua liderança em relação ao seu pessoal. De qualquer forma, o fato é que, mesmo em se tratando de um grupo pequeno de pessoas envolvidas no desenvolvimento do processo de trabalho na área da Saúde, conseguiu-se criar uma relação que transcendeu ao Projeto, a de respeito nas atitudes. Boas recordações ficaram, dentre elas, um certo dia, enquanto se esperavam alguns integrantes terminarem suas atividades de rotina em suas salas, (normalmente, o treinamento tinha início às 10:30 horas), o grupo foi tomar café e comer bolo de côco e bolacha maisena com margarina. Conversas e comentários diferentes do assunto saúde surgiram, mais relacionados com a vida pessoal de cada um. Eram mulheres e mães, em sua maioria, com idades variadas e grande parte morava na Cidade; o grau de instrução não era mais que o técnico, fato irrelevante pois, a importância delas para o serviço era quase que fundamental, eram elas quem construíam, dia após dia, a dinâmica da unidade de saúde.

O Projeto com o pessoal da Pastoral da Criança, após ter-se apresentado, iniciou um período de organização das pessoas que estavam se envolvendo.

Foram estabelecidos, junto aos participantes, as datas e horários que fossem adequados para todos os treinamentos e visitas à comunidade para acompanhamento do desenvolvimento do conteúdo prático (Fotos 18 e 19). 
O treinamento compreendeu dois encontros para a parte teórica, com duas horas/encontro, além de cinco para a parte prática, para exercitar a triagem visual entre crianças "carentes" de Morungaba, em particular, da zona rural.

Todos eles receberam uma pasta, contendo: manual de Promoção da Saúde Ocular, um jogo de mãozinhas prontas, um palito de sorvete com figura de gibi na ponta e folhas em branco $e$, ao final dos trabalhos, o certificado de participação (anexo 17 e Foto 20)

A disposição dessas pessoas impressionava... Elas iam às casas das pessoas da área rural, conversavam, orientavam, eram conhecidas e respeitadas e, com isso, tornava a pesquisadora respeitada, também.

Um comentário de um dos integrantes da Pastoral da Criança ilustra esta percepção:

"Eu nem pensava de ter esta experiência mas, com esta oportunidade e apoio, a gente pode ajudar muitas crianças!"

No momento em que se estava com o grupo nesses locais, sentia-se a própria integrante da Pastoral, guiada por eles.

Simples, diferentes e decisivos eram os seus integrantes, as ações básicas eram vivenciadas, praticadas, porque pegavam e faziam com suas próprias mãos; enquanto que, às vezes, muitos demoram anos e anos na universidade aprendendo conceitos que eles praticam todos os dias.

Um deles falou meio envergonhado:

"Não tenho muita leitura mas tenho carinho e afeto para dar, principalmente para as crianças"... 
Foto 18 - Treinamento teórico sobre Ações Básicas de Saúde Ocular de pessoal da Pastoral da Criança, Morungaba, 2000

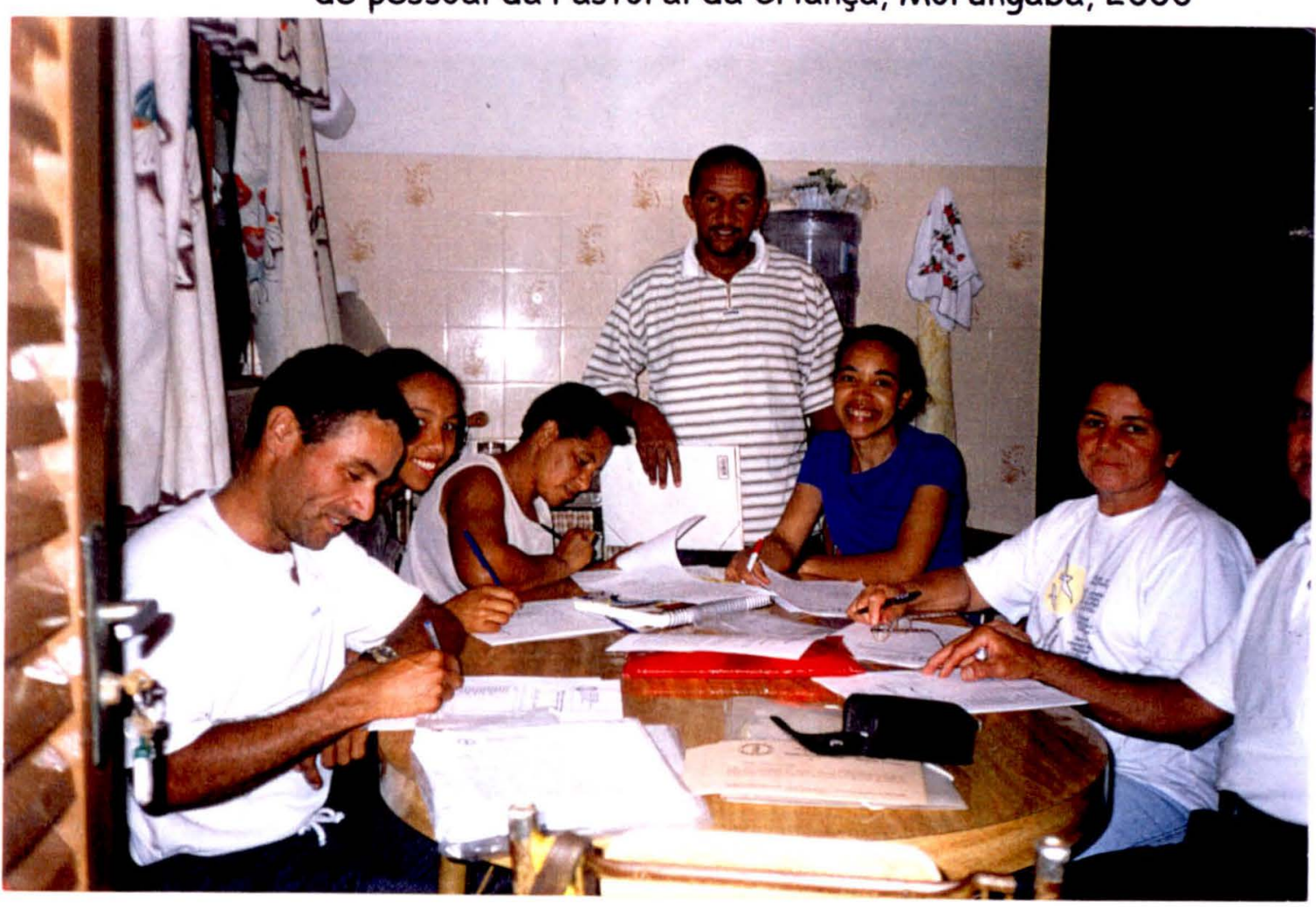

Foto 19 - Treinamento prático sobre Ações Básicas de Saúde Ocular de pessoal da Pastoral da Criança, na zona rural de Morungaba, 2000

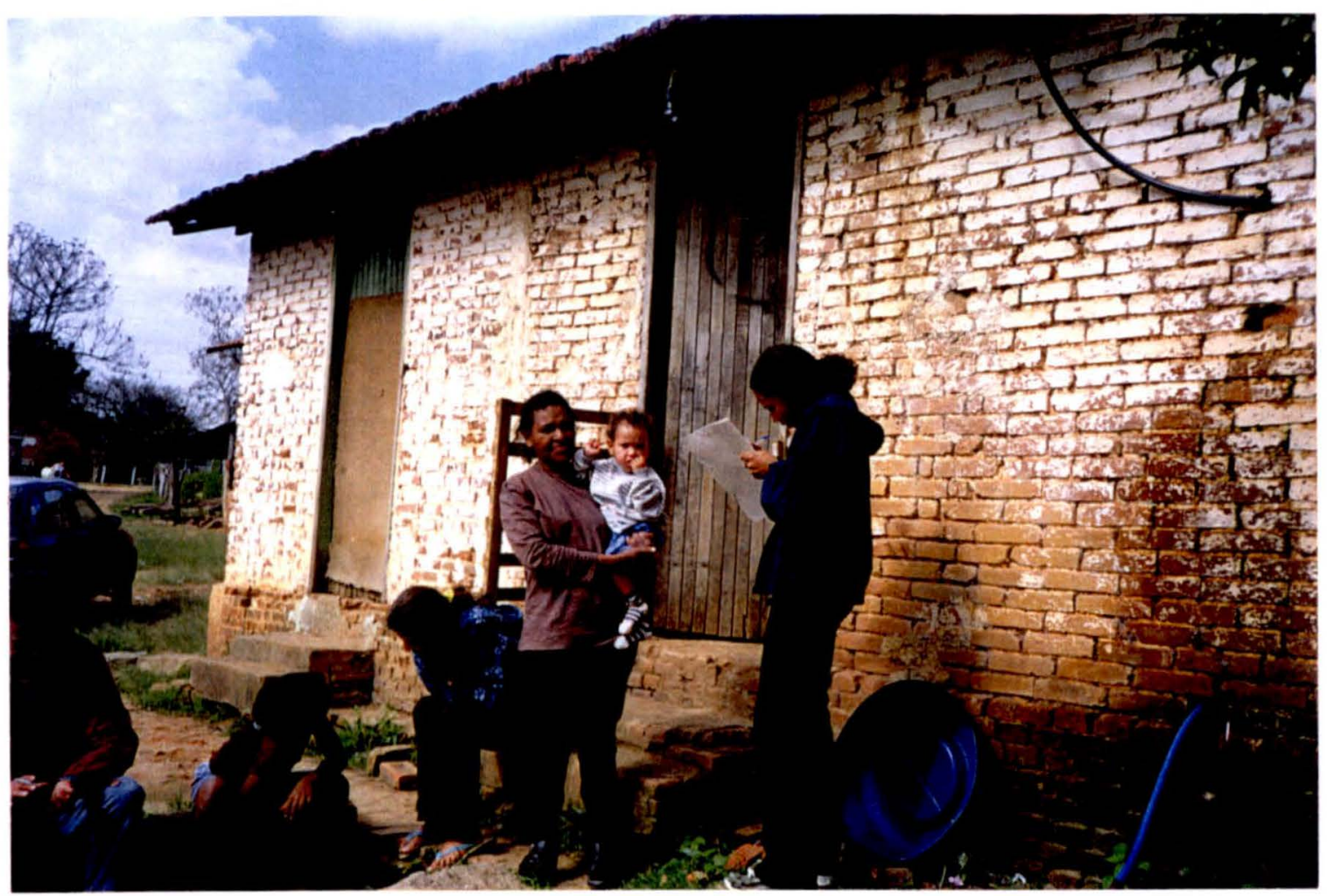


Foto 20 - Pasta com material de treinamento fornecida a todos os participantes, Morungaba, 2000.

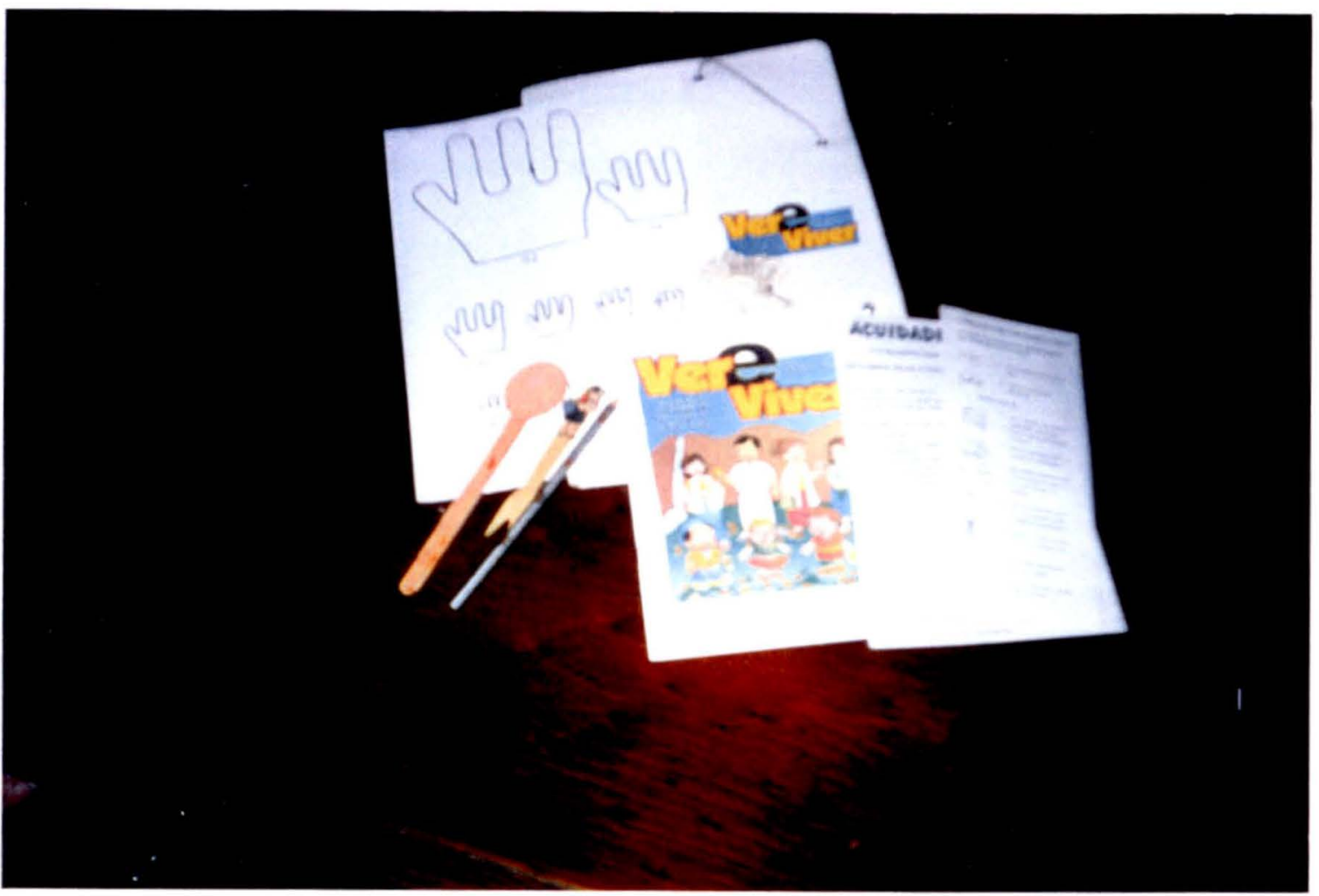

Foto 21 - Pessoal da Pastoral da Criança, realizando triagem visual, utilizando o método "Reação à Oclusão" em crianças da zona rural de Morungaba, 2000.

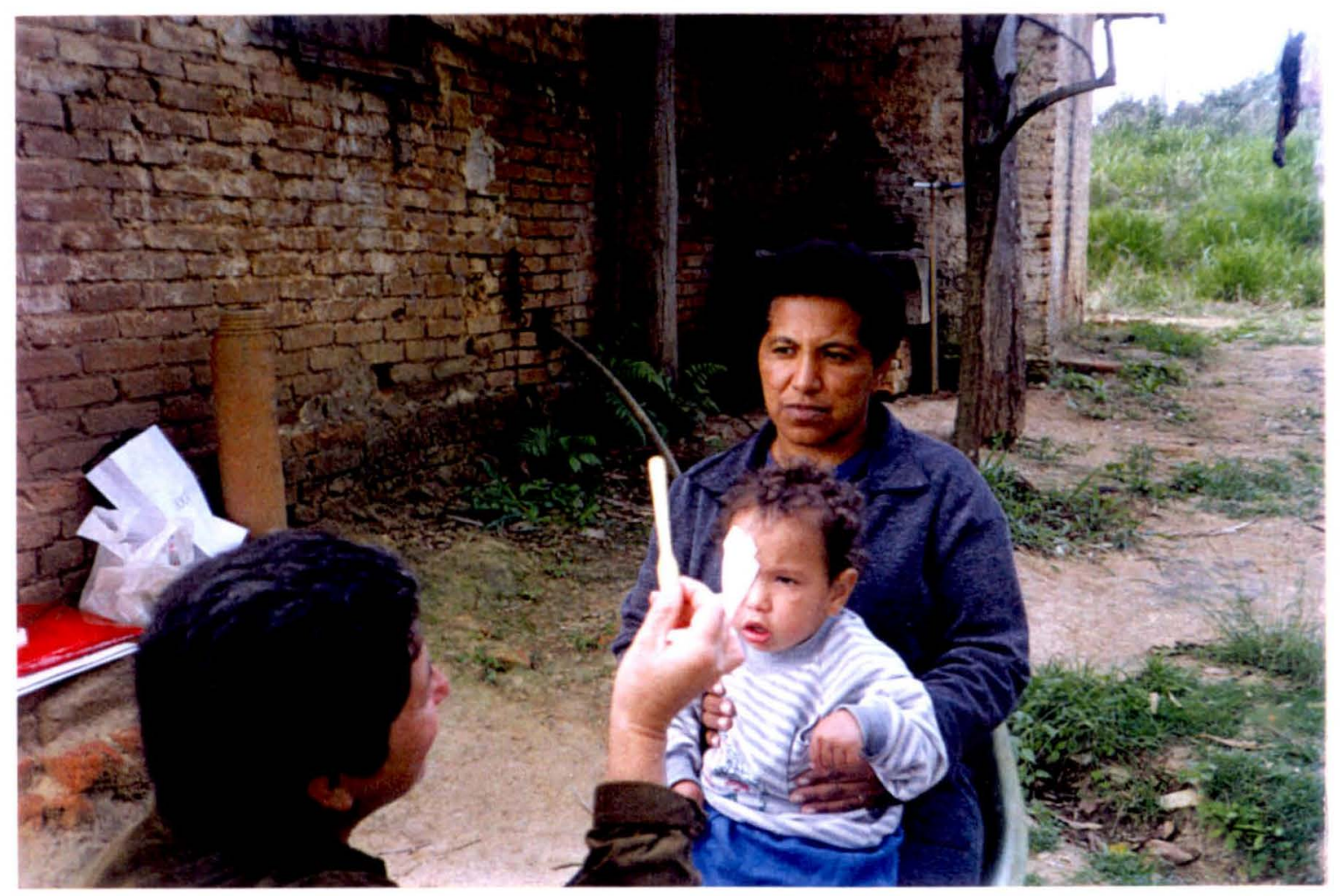


Em uma das noites, houve uma reunião com o grupo, na casa de uma trabalhadora - sem muita instrução, mas o que queria, estava escrito em seus olhos. Lá chegando meio envergonhada, a pesquisadora logo foi se soltando. A casa era bem simples, aconchegante, as pessoas foram chegando e uma nova participante se apresentou, muito sorridente e com um olhar vivo.

Era a filha da dona da casa, que passou a participar do trabalho de saúde ocular durante as visitas à zona rural - jovem de 14 anos, mas com opinião sobre a vida - que estava preocupada com o bolo que havia preparado para esse encontro. Essa reunião foi muito produtiva: revisouse o conteúdo, metas a curto prazo foram definidas, envolvendo outros lugares carentes a serem cobertos, além da discussão sobre as perspectivas de atuação para o ano seguinte, em relação ao trabalho que vinham desenvolvendo com as crianças, de pesar $e$ medir $e$, agora, de realizar a triagem visual, dado que se trata de trabalho que requer a parceria da saúde e da educação (Foto 22).

Foram juntos - a pesquisadora e os voluntários - a diferentes locais da zona rural, alguns já conhecidos. Numa manhã de muito frio, foram visitadas duas famílias que moravam próximas das olarias, na área rural. $A$ beleza dos caminhos já havia sido experimentada, e o carro andava naquelas trilhas pequenas no meio do mato, abre cerca, fecha cerca, até chegar à casa dos moradores selecionados.

A pobreza das pessoas era visível: crianças com o mínimo de agasalhos, pés no chão, e a moradia: um casebre, outra de tijolo com madeira e folhas de papelão e zinco (Foto 23). 
Foto 22 - Teste de Snellen realizado pelo pessoal da Pastoral da Criança na zona rural, Morungaba, 2000.

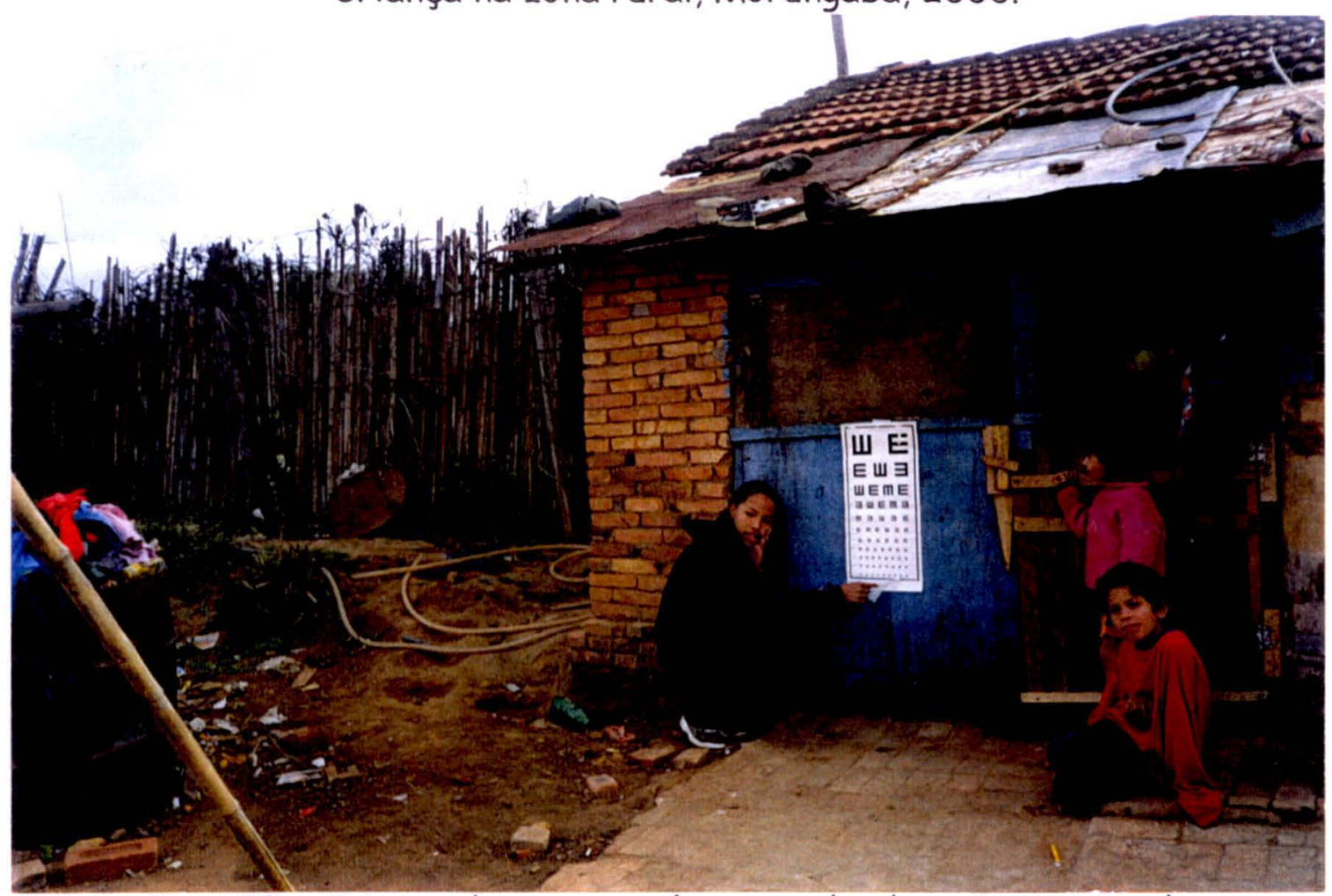

Foto 23 - Criança da zona rural, respondendo ao teste visual, aplicado por pessoal da Pastoral da Criança, Morungaba, 2000.

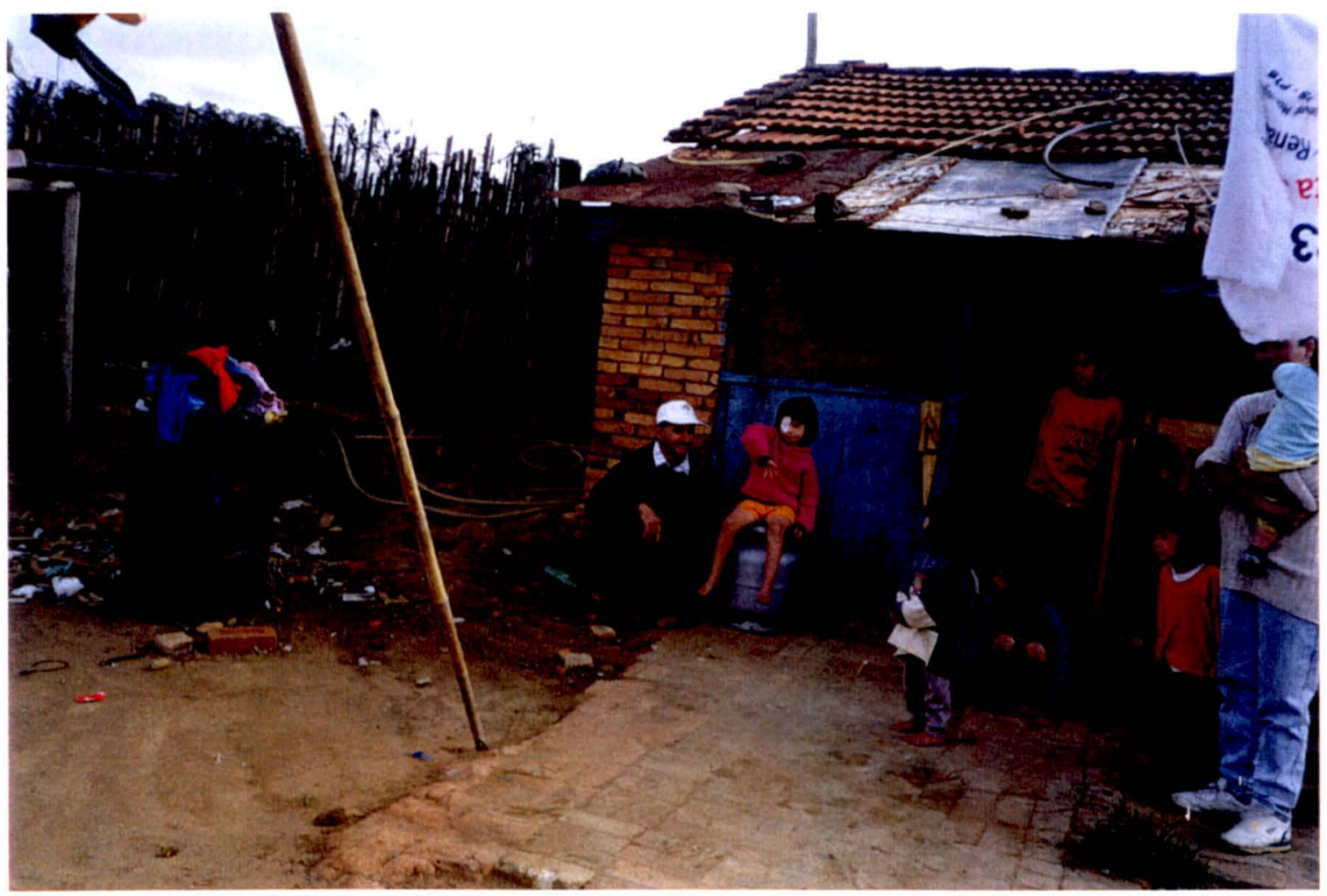


Para esta pesquisadora, foi muito triste verificar que, no seio daquela natureza, havia uma pobreza tão escancarada...

O que iria ser feito ali?... perguntou-se, assim que o Coordenador parou o carro...

Não tinha nada a oferecer, a não ser carinho, atenção, um pouco de conhecimento sobre saúde ocular para aplicar nos filhos daquelas mulheres abatidas pela vida, além de algumas balas para as crianças. Ficou pensativa, enquanto o coordenador contava a história de cada família... aquela conversa a foi tranquiilizando, ao pensar que eles, pelo menos, não estavam sozinhos.

Em uma das casas, a mãe com oito filhos, todos em casa, ainda conseguia sorrir, os seus filhos vinham em sua direção à busca de um carinho. A cena presenciada emcionou. A vontade era de arrumar tudo que estava jogado, limpar o quintal, dar banho nas crianças, mas se percebeu que não era apenas disto que estava precisando: ela, também, precisava de carinho, de atenção de alguém, de uma casa melhor para morar, de coisas para sua casa...

A dona da casa pediu desculpas, porque não havia cadeira em sua casa para sentar, eles estavam acostumados a se sentarem no chão...

"A senhora me desculpa não ter cadeira para "oces" sentar..."

Sentou seus filhos em um botijão de gás, adaptado pelo pessoal da Pastoral da Criança com uma tábua, para que a triagem visual pudesse ser realizada. Os testes foram aplicados em todas as crianças, com idade de um até 14 anos. Todas em idade escolar, estavam freqüentando a escola estadual do bairro e nenhum deles apresentou problemas identificáveis nos olhos, por ocasião da triagem. 
Enquanto o trabalho era feito, o Coordenador da Pastoral entrou no mato para procurar uma erva para fazer chá para as crianças, pois a maioria delas estava resfriada. Encontrou o que procurava, ensinou a mãe a preparar, explicando na linguagem dela, enquanto ela agradecia.

Às vezes, aquela mulher forte é lembrada, com o menino no colo, os outros filhos ao seu redor, com seus olhos claros, sem alguns dentes na frente, sorridente porque o marido havia arranjado trabalho na cidade vizinha. A vontade era de ficar conversando com ela, mas o tempo já havia passado e era necessário ir embora.

Sempre estavam em contato - o coordenador da Pastoral e a pesquisadora - para combinarem os próximos passos e, a cada contato, percebia-se uma nova disposição do grupo para se envolver mais no processo de trabalho.

"As coisas boas do Projeto é que vai ajudar crianças"

Com as Mães dos alunos da EMEI São Benedito, o Projeto se desenvolveu de forma lenta, ou seja, elas, em sua maioria, restringiam-se a levar seus filhos ao centro de saúde, como todas as outras mães, quando thes era solicitado. Um grupo pequeno de mães participou do treinamento e do acompanhamento da parte prática, do qual, três apenas conseguiram realizar as atividades propostas em sua comunidade (Fotos 24 e 25). 
Foto 24 - Treinamento teórico em Ações básicas de Saúde Ocular de mães de crianças menores de 7 anos de idade, da EMEI São Benedito, Morungaba, 2000.

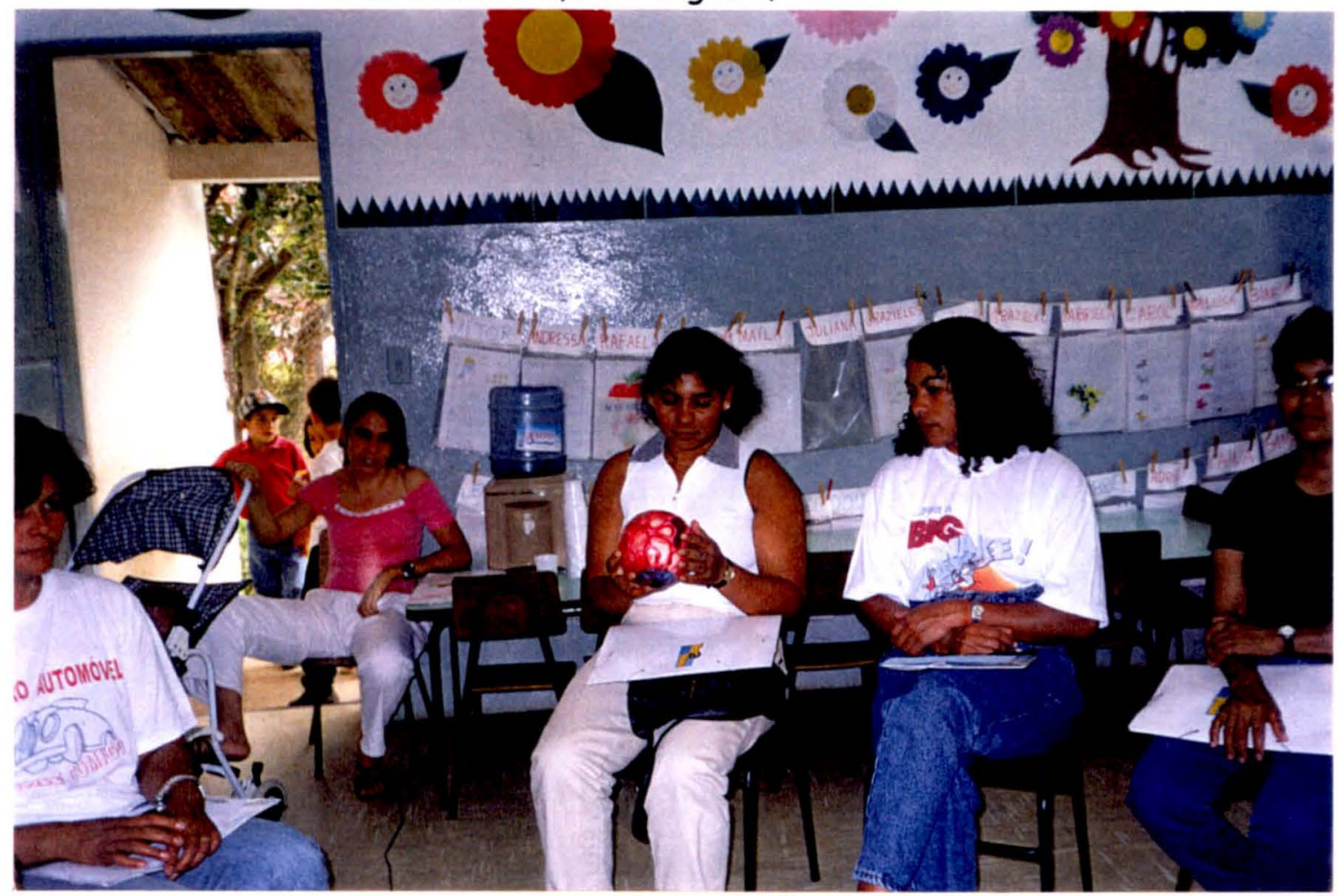

Foto 25 - Treinamento prático em Ações Básicas de Saúde Escolar com mães, Morungaba, 2000.

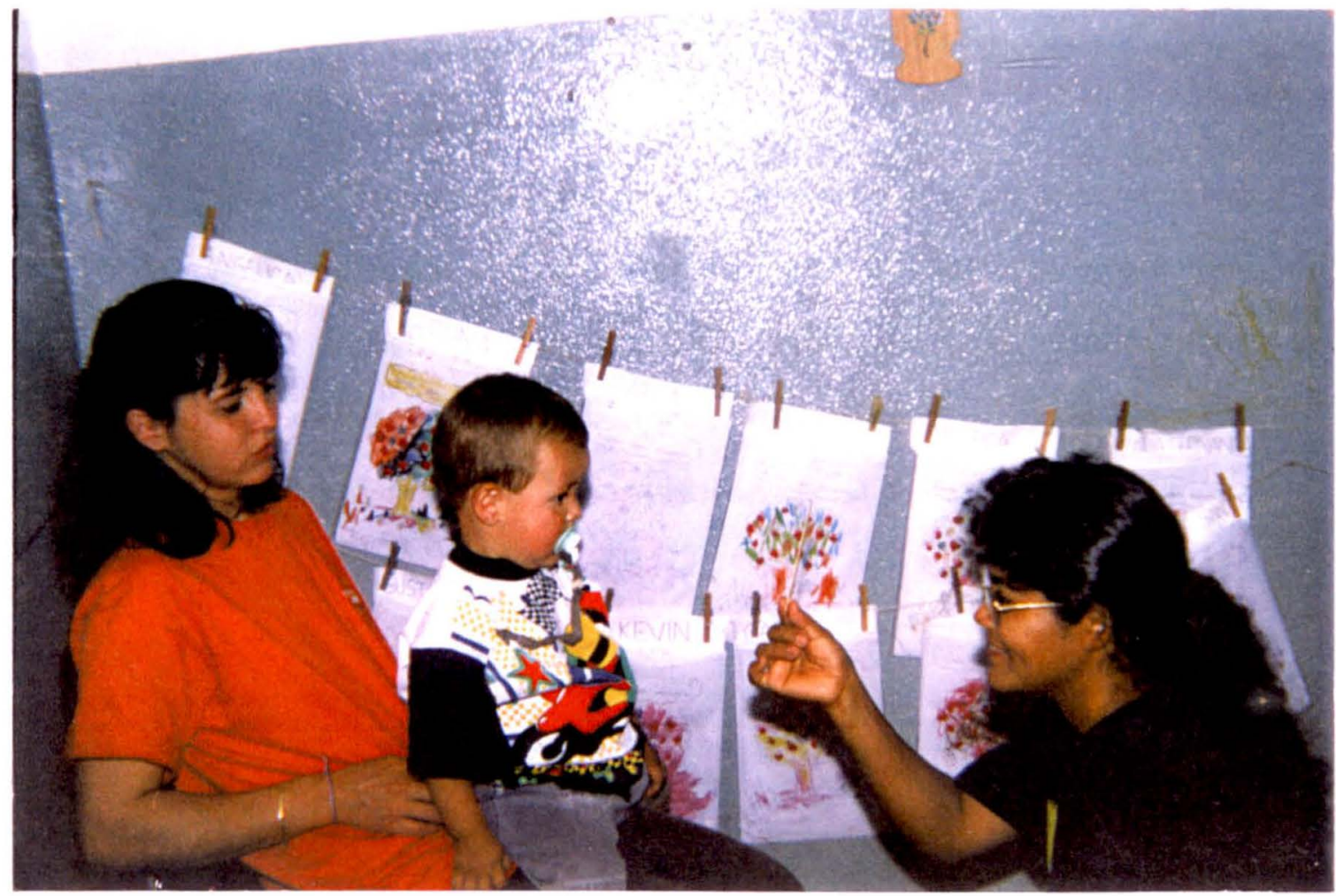


Uma das participantes não era mãe de criança, da EMEI, nem era do bairro, apenas tinha vindo acompanhar a amiga ao treinamento. Morava na zona rural, mostrou-se muito interessada e participou de todos os outros encontros, manifestando o desejo de desenvolver o trabalho em seu bairro que, segundo ela, contava com algumas crianças.

Uma outra mãe não queria que o treinamento acabasse, porque havia gostado muito do assunto e tinha aprendido bastante.

Um dos prováveis fatores que interferiram na baixa frequiência de mães às atividades do Projeto, pode ter sido o fato de que a maioria delas trabalhava meio período, ou à noite, inclusive aos sábados, não dispondo de tempo para outras atividades, que não cuidar da casa e das crianças. Mesmo assim, no espaço com que se contou, procurou-se conhecer uma às outras, rir, brincar, conversar sobre as dificuldades da vida $e$ preocupações com os filhos no mundo de hoje.

Notava-se, durante os encontros, que muitas delas estavam nitidamente cansadas, quando, então, fazia-se o intervalo para tomar um cafézinho ou suco, com bolo.

A Diretora da Educação foi quem providenciou o local para a realização dos treinamentos, na própria EMEI São Benedito, assim como o café, o suco, salgados e o bolo.

Um resultado qualitativo desse momento, e que merece destaque, é que, com a mudança político-administrativa local, durante o andamento do processo, a nova Prefeita de Morungaba, ao tomar conhecimento do Projeto, solicitou a seus Diretores e Assessores providenciarem o que fosse necessário para que continuasse sendo desenvolvido na Cidade. 
A pesquisadora foi convidada a participar de reuniões (em 2001) na Saúde e na Prefeitura (anexo 19), para colaborar com a sua leitura sobre sucessos e dificuldades no processo de construção do Projeto, dentro da intenção apresentada de aprimorá-lo e prosseguir em seu desenvolvimento nos próximos anos, perseguindo o objetivo proposto.

Os atores sociais locais, sobretudo os representantes políticoadministrativos, tomaram para si o Projeto, porém, ainda sem prescindir da participação da pesquisadora.

\section{Momento - revisão, replanejamento e sistematização:}

Nesse momento, que correspondeu ao da redação da presente tese, considerou-se conveniente estar apresentando, em primeiro lugar, os resultados globais obtidos no processo descrito para, em seguida, proceder-se à análise do processo.

O Projeto de Promoção da Saúde Ocular e Prevenção de Problemas Visuais, desenvolvido no município de Morungaba, São Paulo, no período de 1999 a 2000 , envolveu mais de 800 pessoas, de uma população total de 9.657 habitantes (Censo Demográfico 2000 - IBGE 2001). O grupo de estudo compreendeu: crianças, mães, professores, monitores de creches, pessoal da Pastoral da Criança, lideranças político-locais, membros do Conselho Municipal de Saúde, empresários, trabalhadores dos setores municipais e estaduais da Saúde e da Educação, profissionais dos meios de comunicação escrita e televisiva.

Após cerca de 12 meses de encontros formais e informais de aproximação, de conhecimento preliminar do Município, reuniões com 
atores sociais, busca de articulações, parcerias e estímulos injetados gradativamente, o Projeto foi ganhando forma e volume, num movimento em cascata, com participação cada vez maior dos envolvidos, na direção da melhoria da qualidade de saúde ocular das crianças desse município.

Desconhecida, estranha de início, a pesquisadora passou a ser reconhecida como "aquela pessoa que cuida dos olhos da gente", integrando-se em um processo de avanços e recuos, mergulhando, por inteira, na consecução desta proposta.

Finda a fase inicial, desencadeou-se o processo de fortalecimento dos diferentes atores sociais, no que diz respeito à área de saúde ocular, mediante sua instrumentalização em relação a conhecimentos básicos sobre o tema, ocorrida em forma de treinamentos sucessivos, com duração de dois meses, possibilitando-thes a apropriação do saber específico e a, partir daí, a construção/ definição dos passos seguintes. Participaram desses treinamentos 61 atores sociais de diferentes setores e áreas - professores, monitores de creche, pessoal da saúde, voluntários da Pastoral da Criança e mães de crianças de 0-7 anos de idade, moradoras do Bairro São Benedito.

Conforme referido anteriormente, o enfoque adotado nesses treinamentos, em matéria de relações pedagógicas, foi na linha dialógica, de trocas, a partir de conhecimentos de que eram portadores os seus participantes, em que o pesquisador se colocou como um facilitador do processo ensino-aprendizagem, diferentemente da concepção de educação bancária, tal como apresentada por Freire (FREIRE, s/d). Os treinamentos transcorreram em um clima de cordialidade, entusiasmo e de respeito mútuo entre todos. 
Esse processo não se deu sem dificuldades e de maneira uniforme com os distintos grupos. A título de exemplo, o grupo de mães foi o que apresentou maiores dificuldades para participar dos encontros, com alegações de falta de tempo, devido a serem operárias, em sua grande maioria, com jornada semanal, incluindo os sábados. Apesar de diferentes alternativas de horário apresentadas, foi pequeno o número de mães participantes. Vale assinalar que essa constatação pôde ser observada em outra situação - reunião de pais e mestres na escola pública local - em que a presença de pais foi proporcionalmente reduzida, não obstante tratar de assuntos referentes a seus próprios filhos. Essa dificuldade, também, foi verificada com o pessoal da Saúde.

Realizados os treinamentos teórico-práticos, procedeu-se ao planejamento e execução de atividades em salas de aula, envolvendo, sobretudo, os professores da rede municipal e estadual de ensino e das escolas privadas envolvidas, que implicou a escolha de estratégias adequadas a cada grupo etário para a prática educativa com crianças de 0 a 7 anos de idade, prioritariamente. Esse trabalho expressou um momento de iniciativas, de criação de alternativas a partir de utilização de material disponível, privilegiando a participação das crianças como sujeitos do processo.

As atividades diretas com crianças da população-alvo espelharam o processo de trabalho desenvolvido durante os treinamentos, mediante o estabelecimento de uma relação prazerosa entre os participantes, valorizando a experiência e a criatividade, que resultou na produção de material importante a respeito de saúde ocular e motivo de uma exposição especial aberta para a comunidade, conforme já relatado. 
Fez parte, também, dessas atividades diretas, o preparo das crianças para se submeterem a diferentes tipos de testes visuais, após o que os professores e demais participantes aplicaram os testes selecionados em salas de aula. Quando detectada a suspeita de alteração visual em alguma criança, foi realizado o reteste para confirmação e, em caso afirmativo, encaminhado para o serviço de saúde, sob supervisão técnica da pesquisadora.

Os mesmos procedimentos foram realizados com o pessoal da Pastoral da Criança e as mães: convite para participar do Projeto, treinamento teórico-prático, orientação em relação à saúde ocular, aplicação de teste de acuidade visual em crianças e encaminhamento para o serviço de saúde daquelas em que foram detectadas alterações visuais.

O pessoal de saúde recebeu, da mesma forma, todo o treinamento necessário.

No serviço de saúde, a criança encaminhada era reavaliada pelo pessoal de enfermagem, para posterior encaminhamento ao médico oftalmologista.

Após a consulta oftalmológica, a criança que necessitava de óculos era encaminhada para o serviço enfermagem do Centro de Saúde para experimentar o tamanho da armação e o modelo mais adequado para ela.

Concluida essa etapa, o enfermeiro responsável dirigia-se à fábrica de armações de óculos Sorel, de quem recebia a armação e, em seguida, a própria mãe a levava à ótica Nossa Senhora do Belém, com a receita médica, para confecção das lentes prescritas. Ressalva-se que as doações, tanto de armações quanto de lentes, eram realizadas apenas mediante apresentação da receita, carimbada, do oftalmologista do 
Centro de Saúde do Município, para que os responsáveis das duas empresas parceiras tivessem controle de saida do estoque, de armações e lentes.

As crianças que necessitaram exames de controle médico tiveram acompanhamento no próprio serviço de saúde local.

Aquelas que necessitaram de assistência à saúde ocular, requerendo tecnologias de maior complexidade, foram encaminhadas para os serviços públicos de referência, em nível terciário, no Município de Itatiba e/ou Jundiaí.

\section{2 - Resultados em construção}

Para se ter uma idéia mais concreta da abrangência do Projeto no Município, são apresentados alguns dados referentes a atividades de triagem, desenvolvidas com crianças por atores sociais, bem como os resultados encontrados em relação aos conhecimentos sobre saúde ocular e o significado por eles atribuido ao Projeto.

O total de atores sociais envolvidos, durante o processo de desenvolvimento do Projeto, foi de 61 pessoas, como pode ser observado na Tabela 1. 
Tabela 1 - Distribuição dos atores sociais treinados em saúde ocular em relação ao total existente, Município de Morungaba, 2000.

\begin{tabular}{lccccc}
\hline Atores sociais & $\begin{array}{c}\mathrm{N}^{0} \\
\text { Total } \\
(\boldsymbol{A})\end{array}$ & $\begin{array}{c}\mathrm{N}^{0} \text { de } \\
\text { treinados } \\
(\mathrm{B})\end{array}$ & $\%$ & $\mathrm{~B} / \mathrm{A} 100$ \\
\hline $\begin{array}{l}\text { Pessoal da Educação } \\
\text { Monitoras Creche }\end{array}$ & 33 & 16,3 & 33 & 54,1 & 100 \\
Pessoal da Saúde & 13 & 6,4 & 8 & 13,1 & 61,5 \\
Pastoral da Criança & 6 & 3.0 & 6 & 9,8 & 100 \\
Mães* & 150 & 74,3 & 14 & 23,0 & 9,3 \\
\hline TOTAL & 202 & 100 & 61 & 100 & 30,2
\end{tabular}

* De acordo com o critério populacional definido para este estudo, levou-se em consideração apenas as mães do bairro de São Benedito.

O universo populacional deste estudo correspondeu a 202 atores sociais, entretanto, levando-se em consideração o teor do estudo proposto, qual seja, de descrever a percepção sobre saúde ocular, promoção da saúde, prevenção de problemas visuais e identificar os conhecimentos adquiridos no treinamento, como uma das etapas metodológicas, optou-se trabalhar apenas com os atores sociais treinados.

Desta forma, a população do estudo constituiu-se de 61 atores sociais. Com a intenção de mapear os atores sociais envolvidos, conforme a sua localização relacional, tendo como matriz, a estrutura da Prefeitura do Município de Morungaba, é apresentada a representação gráfica no anexo 22.

De acordo com a tabela 1, os professores e monitores de creche e 0 pessoal da Pastoral da Criança representaram a totalidade existente no Municipio, com $100 \%$ de participação, enquanto que o pessoal de saúde, 
$61,5 \%$ e as mães, apenas $9,3 \%$. Vale ressaltar que, do total de mães do bairro escolhido, 72 delas foram contatadas, mas apenas 14 participaram do treinamento.

A ausência de grande contingente de mães pode ser considerada, em parte, compreensivel e esperada, dada a dificuldade a que se referiram: dupla jornada de trabalho, que absorvia todo o tempo das mesmas, inclusive aos domingos, merecendo, entretanto, ser melhor avaliada, na continuidade do processo.

Por considerar oportuno possibilitar uma idéia sobre o perfil dos participantes, neste momento, assinalam-se algumas características da composição dos grupos envolvidos, quanto a:

- sexo - o grupo primou por ser basicamente feminino, com apenas $4,9 \%$ (3) do sexo masculino:

- idade - adultos jovens - mediana de idade: 35 anos, idade mínima de 14 anos e a máxima, 61 anos:

- escolaridade, que variou desde analfabetos, até pessoal com nível superior: dentre o pessoal da Educação, do total de 33 professores, $51,5 \%$ possuíam curso superior, sendo o nível de educação fundamental incompleto mais freqüente entre as mães, em sua maioria, operárias, e pessoal da Pastoral da Criança, constituído de voluntários da comunidade.

Em relação ao trabalho realizado pelos diferentes grupos de atores sociais, são apresentados na Tabela 2, dados referente à triagem. 
Tabela 2 - Número de crianças que foram triadas, segundo as categorias de atores sociais, Morungaba, 2000.

\begin{tabular}{lcc}
\hline Atores sociais & $N^{0}$ de crianças & $\%$ \\
\hline Professores e monitores de & $846^{\star}$ & 86,5 \\
creche & 20 & 2,4 \\
$\begin{array}{l}\text { Pessoal da Saúde } \\
\text { Pastoral da Criança }\end{array}$ & 100 & 10,1 \\
Mães & 15 & 1,5 \\
\hline $\begin{array}{l}\text { TOTAL } \\
\text { *Crianças de até a quarta série, que foram incluídas no Projeto } \\
\text { pelos professores, com o apoio da Diretora da Escola Estadual de } \\
\text { Ensino Fundamental, situação não prevista no início do processo. }\end{array}$
\end{tabular}

O total de crianças triadas pelos distintos atores sociais correspondeu a 981.

Conforme a proposta inicial de estudo, a população-alvo compreendia crianças de 0 a 7 anos de idade, entretanto, no processo concreto, os próprios atores sociais, isto é, professores da rede estadual de ensino fundamental, junto com a direção da escola, decidiram, por sua iniciativa, ampliar a triagem para crianças acima de 07 anos, ou seja, alunos até a quarta série do primeiro grau, dada a importância atribuída a esse trabalho e à capacidade instalada para sua execução.

Ressalta-se o esforço despendido pelos professores e monitores de creche, que triaram 846 crianças, correspondentes a $86,5 \%$ do total de crianças abrangidas pelo Projeto.

Assim, considerando a faixa etária selecionada para este estudo, 0 a 7 anos, o total de crianças triadas correspondeu a 722 , o que pode ser verificado na Tabela 3. 
Tabela 3 - Número e proporção de crianças de 0 a 7 anos triadas, segundo os atores sociais que participaram do Projeto, Morungaba, 2000.

\begin{tabular}{lrr}
\hline Atores sociais & $\begin{array}{c}\mathrm{N}^{0} \text { de } \\
\text { crianças }\end{array}$ & $\%$ \\
\hline Professores e monitores de & 587 & 81,3 \\
creche & 20 & 2,8 \\
Pessoal da Saúde & 100 & 13,8 \\
Pastoral da Criança & 15 & 2,1 \\
Mães & 722 & 100 \\
\hline TOTAL &
\end{tabular}

O total de crianças triadas por estes atores sociais (722), correspondeu a $51,6 \%$ da população total de crianças de 0 a 7 anos do Município (Censo Demográfico - 2000. IBGE).

Este dado demonstra que o Projeto conseguiu atingir uma boa cobertura, ao se considerar o curto período que compreendeu a triagem, (8 meses), o volume e a complexidade do trabalho que a envolveu. Entretanto, ressalta-se que um grande número de crianças ainda não passou pela triagem $(48,4 \%)$, necessitando, portanto, a continuação do mesmo, tendo como alvo uma cobertura de $100 \%$, por se tratar de um projeto que visa à promoção e à prevenção.

A distribuição dessas crianças, segundo a faixa etária, pode ser verificada na Tabela 4. Como foi dito acima, os professores junto à Direção da Escola Estadual de Ensino Fundamental Antonio Rodrigues, por iniciativa própria, ampliaram o número de crianças a serem triadas, envolvendo, também, os alunos de $2^{a}$. a $4^{a}$. séries da referida Escola. 
Tabela 4 - Frequiência de crianças da Creche, da Educação Infantil e Ensino Fundamental das escolas Municipais, Estaduais, Estaduais Rurais e Privadas, que foram triadas pelos professores e monitores de creche, até a quarta série do Ensino Fundamental das Escolas Estaduais, Morungaba, segundo faixa etária, 2000.

\begin{tabular}{ccc}
\hline $\begin{array}{c}\text { Faixa Etária } \\
\text { (anos) }\end{array}$ & $\begin{array}{c}\text { Crianças Triadas nas escolas } \\
\mathrm{N}^{0}\end{array}$ & $\%$ \\
\hline $0-1$ & 6 & 0,7 \\
$2-3$ & 41 & 4,8 \\
$4-5$ & 184 & 21,7 \\
$6-7$ & 356 & 42,1 \\
SUB-TOTAL & 587 & 69,4 \\
$\geq 8$ & 259 & 30,6 \\
\hline TOTAL & 846 & 100 \\
\hline
\end{tabular}

Nas Escolas Estaduais Rurais do Município, 4 salas de aulas concentravam crianças da primeira à quarta série e, conseqüentemente, a faixa etária encontrada ultrapassava os 7 anos de idade. Nesses termos, ficava difícil excluí-las das atividades programadas, principalmente no que se referia ao teste de acuidade visual, razão pela qual a Diretoria de Educação decidiu estender a faixa etária, incluindo esses alunos, conforme foi relatado anteriormente.

Essas mudanças - alteração da população alvo do estudo, de crianças de 0-7 anos para crianças acima de 7 anos - foram assumidas pelo sujeito pesquisador também, uma vez que o Projeto do Promoção se caracterizava como um processo de construção coletiva, ou seja, que não 
dependia apenas do pesquisador para o desenrolar do mesmo e sim do conjunto de atores sociais envolvidos, frente a uma realidade concreta.

Para se ter uma idéia da magnitude das crianças matriculadas e triadas na creche, educação infantil e ensino fundamental, apresentamos na tabela 5 o número de crianças matriculadas, segundo o Censo Escolar, e as taxas de triagem correspondentes.

Tabela 5 - Taxa de crianças triadas na Creche, na Educação Infantil e no Ensino fundamental (até a quarta série), em relação ao número de crianças matriculadas segundo o Censo Escolar 2000. Morungaba, 2000.

\begin{tabular}{|c|c|c|c|c|c|}
\hline \multirow[b]{2}{*}{$\begin{array}{c}\text { Tipo de unidade } \\
\text { escolar }\end{array}$} & \multicolumn{2}{|c|}{ Censo Escolar } & \multicolumn{2}{|c|}{ Crianças triadas } & \multirow{2}{*}{$\begin{array}{c}\text { Taxa } \\
(B / A 100)\end{array}$} \\
\hline & $\begin{array}{l}N^{0} \\
(A)\end{array}$ & $\%$ & $\begin{array}{l}N^{0} \\
(B)\end{array}$ & $\%$ & \\
\hline Creche Municipal & 63 & 6,5 & 63 & 7.4 & 100 \\
\hline EMEI & 281 & 29,1 & 250 & 29,6 & 89,0 \\
\hline EMEF & 101 & 10,4 & 98 & 11,6 & 97,0 \\
\hline Estadual Urbana & 354 & 36,6 & 273 & 32,3 & 77,1 \\
\hline Estadual Rural & 96 & 9,9 & 90 & 10,6 & 93,7 \\
\hline Privadas & 72 & 7,5 & 72 & 8,5 & 100 \\
\hline TOTAL & 967 & 100 & 846 & 100 & 87,5 \\
\hline
\end{tabular}

Observa-se que o número de crianças triadas pela Escola Estadual de Ensino Fundamental na região urbana - Antonio Rodrigues, foi proporcionalmente maior $(32,3 \%)$ que as demais unidades, seguida das Escolas Municipais de Educação Infantil (29,6\%). Entretanto, para se ter uma idéia concreta da assertiva, acima descrita, é necessário compará-los com os dados do Censo Escolar. 
A cobertura global foi de $87,5 \%$ de crianças triadas, tendo, como base, os dados do Censo Escolar - 2000. A cobertura das escolas privadas e Creche Municipal atingiu 100\%, enquanto que a Escola Estadual de Ensino Fundamental, da área urbana, foi de $77,1 \%$, necessitando, portanto, da continuação do trabalho de orientação e de triagem visual.

Nas demais unidades escolares, a cobertura da triagem visual variou de $89,0 \%$ a $97,0 \%$, podendo-se considerar que, de modo geral, houve uma boa cobertura, principalmente ao se levar em conta o tempo em que se deu a referida triagem -8 meses.

É importante assinalar os resultados de triagem, referentes à população-alvo deste estudo - crianças de 0 a 7 anos de idade, segundo tipo de unidade - Tabela 6. 
Tabela 6 - Taxa de crianças de 0 a 7 anos de idade triadas, entre matriculadas* na creche, nas escolas de educação infantil e ensino fundamental, segundo tipo de unidade escolar, Morungaba, 2000.

\begin{tabular}{|c|c|c|c|c|c|}
\hline \multirow[b]{2}{*}{$\begin{array}{c}\text { Tipo de unidade } \\
\text { escolar }\end{array}$} & \multicolumn{2}{|c|}{ Censo Escolar } & \multicolumn{2}{|c|}{ Crianças triadas } & \multirow{2}{*}{$\begin{array}{l}\text { Diferenço } \\
(B / A 100)\end{array}$} \\
\hline & $\begin{array}{l}N^{0} \\
(A)\end{array}$ & $\%$ & $\begin{array}{l}N^{0} \\
(B)\end{array}$ & $\%$ & \\
\hline Creche Municipal & 63 & 10,0 & 63 & 10,7 & 100 \\
\hline EMEI & 281 & 44,8 & 250 & 42,6 & 89,0 \\
\hline EMEF & 101 & 16,1 & 98 & 16,7 & 97,0 \\
\hline Estadual Urbana & 86 & 13,7 & 80 & 13,6 & 93,0 \\
\hline Estadual Rural & 24 & 3,8 & 24 & 4,1 & 100 \\
\hline Privadas & 72 & 11,5 & 72 & 12,3 & 100 \\
\hline TOTAL & 627 & 100 & 587 & 100 & 93,6 \\
\hline
\end{tabular}

* Dados do Censo Escolar de Morungaba, 2000.

Consideradas as crianças que na data da triagem tinham até 7 anos de idade.

A cobertura total alcançada nesta faixa etária nas diferentes unidades escolares foi de $93,6 \%$. Quando vista, segundo os tipos de unidade escolar, essa variou entre $89,0 \%$ a $100 \%$, o que pode ser considerado um excelente resultado. A mais baixa cobertura obtida foi nas Escolas Municipais de Educação Infantil - 89,0\% - mas que ultrapassou a meta pretendida pelo Projeto, quando apresentado para as autoridades locais, que era de $80 \%$ para essa faixa etária.

A Tabela 7 apresenta a proporção de crianças menores de 7 anos com problemas visuais, segundo o grupo etário. ${ }^{8}$

\footnotetext{
${ }^{8}$ Os dados referentes aos resultados da triagem visual realizada pelo pessoal da saúde e pelas mães, ainda não estão disponiveis.
} 
Tabela 7 - Proporção de crianças menores de 7 anos com problemas visuais, triadas por professores e monitores da Creche, da Educação Infantil e Ensino Fundamental das escolas Municipais, Estaduais Urbanas, Estaduais Rurais e Privadas, segundo grupos etários. Morungaba, 2000.

\begin{tabular}{ccc}
\hline $\begin{array}{c}\text { Grupos } \\
\text { Etários } \\
\text { (Anos) }\end{array}$ & $\begin{array}{c}\text { Crianças com } \\
\text { problemas } \\
\text { visuais }(\%)^{\star}\end{array}$ & $\begin{array}{c}\text { Total de crianças } \\
\text { triadas nas } \\
\text { escolas e creche }\end{array}$ \\
\hline $0-1$ & 16,7 & 6 \\
$2-3$ & 4,9 & 41 \\
$4-5$ & 10,9 & 184 \\
$6-7$ & 14,0 & 356 \\
\hline TOTAL & 12,4 & 587 \\
\hline *Essas crianças tiveram confirmação diagnóstica no \\
serviço de saúde
\end{tabular}

Em relação à proporção de crianças com problemas visuais encontrados na população de estudo, de acordo com os resultados da pesquisa - $12,4 \%$-, manteve-se dentro dos parâmetros de comparação da literatura científica, que aponta entre 10 a $20 \%$ das crianças em idade escolar, que podem apresentar alguma perturbação oftalmológica. (CBO 1998)

Crianças que não estavam freqüentando a escola/creche representavam, em dezembro de 2000 , cerca de 120 e, a maior parte delas pertencia à faixa etária de 0 a 4 anos. Estas foram triadas, de acordo com a disponibilidade do pessoal da Pastoral da Criança e da Saúde.

Esses dados são apresentados na Tabela 8. 
Tabela 8 - Número e proporção de crianças das Creches e Escolas, segundo tipo de problema visual, por grupo etário, Morungaba, 2000.

\begin{tabular}{lccccccccccc}
\hline & \multicolumn{1}{c}{ Faixa Etária } \\
$\begin{array}{l}\text { Tipos de } \\
\text { problemas }\end{array}$ & $0-1$ & \multicolumn{1}{c}{$2-3$} & \multicolumn{1}{c}{$4-5$} & \multicolumn{2}{c}{$6-7$} & \multicolumn{2}{c}{ Total } \\
& $N^{0}$ & $\%$ & $N^{0}$ & $\%$ & $N^{0}$ & $\%$ & $N^{0}$ & $\%$ & $N^{0}$ & $\%$ \\
\hline Erro & - & - & 1 & 1,4 & 8 & 10,9 & 30 & 41,1 & 39 & 53,4 \\
refracional & & & & & & & & & & \\
Estrabismo & - & - & - & - & 2 & 2,7 & 6 & 8,2 & 8 & 11,0 \\
Ambliopia & - & - & - & - & 2 & 2,7 & 6 & 8,2 & 8 & 11.0 \\
Outros & 1 & 1,4 & 1 & 1,4 & 8 & 11,0 & 8 & 11,0 & 18 & 24,6 \\
\hline Total & 1 & 1,4 & 2 & 2,7 & 20 & 27,4 & 50 & 68,5 & 73 & 100 \\
\hline
\end{tabular}

* OUTROS: Hordéolos, Calázios, Blefarites, Conjuntivites, Ptose Palpebral

Esses resultados encontrados nas atividades de triagem visual, e confirmados em consulta médica, realizadas por professores e educadores de creche durante a implantação do Projeto, estão dentro do esperado, levando-se em conta dados encontrados na literatura científica.

De acordo com a literatura, o problema visual mais prevalente em crianças nesta faixa etária são os erros refracionais que, neste estudo, foi de $53,4 \%$ em relação ao total dos problemas oftalmológicos encontrados, seguidos de estrabismo e ambliopia, 11,0\%; a proporção de crianças com "outros" problemas oftalmológicos aparece em maior proporção do que o estrabismo e ambliopia, mas isto se deve à inclusão de diferentes processos infecciosos, como conjuntivites, hordéolos, calázios, 
blefarites além de outras, não infecciosas mas, não tão freqüente de ser encontrada como é o caso da ptose palpebral.

Com relação ao trabalho de triagem visual, realizado pelo pessoal da Pastoral da Criança, na área de saúde ocular do Município, ressalta-se que essa tarefa representou a primeira experiência da Pastoral, que em sua rotina, mantém-se nas ações de pesagem e medição de estatura, de crianças recém-nascidas até 5 anos idade, com o objetivo de combater a desnutrição.

O grupo da Pastoral se propôs colaborar com o Projeto de Promoção da Saúde Ocular e Prevenção de Problemas Visuais; além das atividades que a fizeram conhecida (Pastoral), em face de sua eficácia e simplicidade, auxiliou sobremodo o Projeto, pelo conhecimento que detinha sobre a comunidade mais carente de Morungaba. Este fato contribuiu para que o Projeto pudesse aumentar a cobertura, principalmente em relação às crianças menores de 3 anos de idade, muitas delas, até então, fora da rede escolar ou creches.

O número de crianças triadas por pessoal da Pastoral da Criança foi 100, seguindo a mesma metodologia de triagem visual utilizada para os professores, citada anteriormente, qual seja, após a triagem da criança, diante de suspeita de alguma dificuldade visual, procedia-se ao resteste $e$, diante da confirmação da suspeita, encaminhamento da criança ao centro de saúde.

O próprio coordenador da Pastoral encarregava-se de levar as crianças com suspeita de algum problema visual até a unidade de saúde. 
Do total das 100 crianças triadas, $10(10,0 \%)$ apresentaram problemas visuais, confirmados por médico oftalmologista, como pode ser demonstrado na Tabela 9:

Tabela 9 - Proporção de crianças com problemas visuais confirmados por médico oftalmologista, sobre o total de crianças triadas pelo pessoal da Pastoral da Criança segundo grupo etário, Morungaba, 2000.

\begin{tabular}{ccc}
\hline $\begin{array}{c}\text { Grupo } \\
\text { Etário } \\
\text { (anos) }\end{array}$ & $\begin{array}{c}\text { Crianças com } \\
\text { problemas } \\
\text { visuais }(\%)\end{array}$ & $\begin{array}{c}\mathrm{N}^{\circ} \text { total de } \\
\text { crianças }\end{array}$ \\
\hline $0-1$ & 10,0 & 30 \\
$2-3$ & 15,0 & 20 \\
$4-5$ & 7,5 & 40 \\
$6-7$ & 10,0 & 10 \\
\hline TOTAL & 10,0 & 100 \\
\hline
\end{tabular}

Pode-se notar uma concentração maior de crianças triadas pelo pessoal da Pastoral nos grupos etários de 4 a 5 anos e 0 a 1 ano, $40,0 \%$ e $30,0 \%$, respectivamente.

Por outro lado, o grupo etário menos triado, foi o de crianças de 6 a 7 anos, 10,0\%, em decorrência da própria definição da população-alvo da Pastoral da Criança, que prioriza a faixa etária de 0 a 5 anos em suas atividades, e dentro dela, as menores de 1 ano.

Em relação à presença de problemas visuais confirmados, a prevalência encontrada foi de $10,0 \%$, condizente com os dados da literatura. 
A distribuição de problemas oftalmológicos, suspeitados na triagem, pelo pessoal da Pastoral da Criança, por grupos etários e com confirmação médica, é apresentada na Tabela 10.

Tabela 10 - Número e proporção de crianças triadas pela Pastoral da Criança, segundo tipo de problema visual, confirmado pelo médico oftalmologista. Morungaba, 2000.

\begin{tabular}{|c|c|c|c|c|c|c|c|c|c|c|}
\hline \multirow{3}{*}{ Tipo de Problemas } & \multicolumn{10}{|c|}{ Grupos Etários } \\
\hline & \multicolumn{2}{|c|}{$0-1$} & \multicolumn{2}{|c|}{$2-3$} & \multicolumn{2}{|c|}{$4-5$} & \multicolumn{2}{|c|}{$6-7$} & \multicolumn{2}{|c|}{ Total } \\
\hline & $N^{0}$ & $\%$ & $N^{0}$ & $\%$ & $N^{0}$ & $\%$ & $N^{0}$ & $\%$ & $N^{0}$ & $\%$ \\
\hline Erro Refracional & - & - & - & - & 1 & 10,0 & - & - & 1 & 10,0 \\
\hline Estrabismo & - & - & 1 & 10,0 & 1 & 10,0 & - & - & 2 & 20,0 \\
\hline Ambliopia & - & - & - & - & 1 & 10,0 & - & - & 1 & 10,0 \\
\hline Outros ${ }^{\star}$ & 2 & 20,0 & 1 & 10,0 & - & - & 1 & 10,0 & 4 & 40,0 \\
\hline Total & 3 & 30,0 & 3 & 30,0 & 3 & 30,0 & 1 & 10,0 & 10 & 100 \\
\hline
\end{tabular}

* OUTROS: Hordéolos, Calázios, Blefarites, Conjuntivites, Ptose Palpebral

Devido ao reduzido número de crianças com problemas visuais, os dados de distribuição, segundo tipos de problemas (Tabela 10), dificultam maiores interpretações a respeito.

$O$ número total de crianças de 0 a 7 anos de idade, triadas por professores, educadores de creche e pessoal da Pastoral da Criança, que apresentaram problemas visuais, confirmados pelo oftalmologista, está descrito na Tabela 11. 
Tabela 11 - Número e proporção de crianças com problemas visuais confirmados por médico oftalmologista, após triagem dos professores, educadores de creche e pessoal da Pastoral da Criança, por grupos etários. Morungaba, 2000.

\begin{tabular}{|c|c|c|c|c|}
\hline \multirow[t]{2}{*}{$\begin{array}{c}\text { Grupo etário } \\
\text { (Anos) }\end{array}$} & \multicolumn{2}{|c|}{$\begin{array}{c}\text { Crianças com } \\
\text { Problemas } \\
\text { Visuais }\end{array}$} & \multicolumn{2}{|c|}{$\begin{array}{l}\text { Total de } \\
\text { Crianças } \\
\text { Triadas }\end{array}$} \\
\hline & $\mathrm{N}^{\circ}$ & $\%$ & $N^{0}$ & $\%$ \\
\hline $0-1$ & 4 & 11,1 & 36 & 1,0 \\
\hline $2-3$ & 5 & 8,2 & 61 & 7,0 \\
\hline $4-5$ & 23 & 10,2 & 224 & 31,4 \\
\hline $6-7$ & 51 & 13,9 & 366 & 60,7 \\
\hline TOTAL & 83 & 12,1 & 687 & 100 \\
\hline
\end{tabular}

A proporção de crianças, com problemas visuais manteve-se relativamente constante, ao reunir os resultados da triagem visual dos dois grupos de atores sociais - dos professores e do pessoal da Pastoral da Criança - mantendo-se dentro dos parâmetros apontados na literatura em relação à prevalência de problemas visuais.

$\mathrm{Na}$ Tabela 12, são apresentados dados sobre o número e proporção de crianças com problema visual, segundo o tipo de serviço de saúde procurado para confirmação diagnóstica. 
Tabela 12 - Número e proporção de crianças com suspeita de problema visual, que recorreram à consulta oftalmológica, segundo o tipo de serviço procurado, Morungaba, 2000.

\begin{tabular}{ccc}
\hline \multirow{2}{*}{ Tipo de serviço } & \multicolumn{2}{c}{ Crianças com } \\
& $\begin{array}{c}\text { problemas visuais } \\
N^{\circ}\end{array}$ & $\%$ \\
\hline Público & 60 & 82,2 \\
Privada & 13 & 17,8 \\
\hline TOTAL & 73 & 100 \\
\hline
\end{tabular}

De acordo com a tabela acima, crianças com suspeita de algum problema visual recorreram, em sua maioria, ao serviço público de saúde, denotando as indicações sugeridas pelos atores sociais. Apenas $18 \%$ delas procuraram os serviços privados de saúde.

Assim, do total de crianças encaminhadas por escolas e creche, $83,2 \%$ delas foram atendidas pelo médico oftalmologista do setor público, enquanto o setor privado foi procurado por $17,8 \%$ delas. Esta situação era esperada, dado que o único oftalmologista existente na Cidade prestava assistência apenas no setor público, sendo mais fácil e menos oneroso para os pais das crianças a ele recorrerem.

As crianças que participaram do Projeto e que necessitaram de óculos em situação de erro refracional, ambliopia e/ou estrabismo, receberam a armação $e$ as lentes da Fábrica Sorel e da Ótica Nossa Senhora do Belém, parceiras do Projeto, tendo sido fornecidos 51 óculos doados, enquanto os demais foram adquiridos através de recursos próprios da família, por opção. 
De acordo com o relatado em capítulo anterior, foi aplicado um questionário entre os participantes, após o treinamento, contendo questões acerca do tema, seja em termos do conhecimento básico, seja sobre significados atribuídos pelos atores sociais locais a questões contidas pelo Projeto.

Dentre as questões, algumas delas permitem obter melhor compreensão da realidade encontrada no presente estudo, razão pela qual são aqui apresentadas:

\section{Sobre o conhecimento básico sobre Saúde Ocular:}

No questionário aplicado aos diferentes atores sociais que participaram do Projeto, foi incluída uma questão, subdividida em cinco perguntas sobre temas específicos, porém básicos sobre saúde ocular (anexo 1). Seguem abaixo os resultados encontrados: 
Tabela 13 - Número e porcentagem de acertos sobre os conhecimentos adquiridos em saúde ocular, segundo o grupo de atores sociais, Morungaba, 2000.

\begin{tabular}{|c|c|c|c|c|c|c|c|}
\hline \multirow[t]{2}{*}{ Conhecimentos sobre saúde ocular } & $\begin{array}{l}\text { Profs. e } \\
\text { monitores de } \\
\text { creche }\end{array}$ & \multicolumn{2}{|c|}{$\begin{array}{l}\text { Pessoal da } \\
\text { saúde }\end{array}$} & \multicolumn{2}{|c|}{$\begin{array}{c}\text { Pessoal da } \\
\text { Pastoral }\end{array}$} & \multicolumn{2}{|c|}{ Mães } \\
\hline & No. & No. & $\%$ & No. & $\%$ & No. & $\%$ \\
\hline
\end{tabular}

\begin{tabular}{|c|c|c|c|c|c|c|c|c|}
\hline Periodo em que ocorre o desenvolvmento visual ' & 26 & 78,8 & 8 & 100,0 & 6 & 100,0 & 7 & 50,0 \\
\hline O que é acuidade visual ${ }^{2}$ & 9 & 27,3 & 4 & 50,0 & 5 & 83,3 & 12 & 85,7 \\
\hline Idade em que se pode avaliar acuidade visual ${ }^{3}$ & 26 & 78,8 & 4 & 50,0 & 5 & 83,3 & 14 & 100,0 \\
\hline Sinais e sintomas de problemas visuais & 32 & 97,0 & 8 & 100,0 & 6 & 100,0 & 14 & 100,0 \\
\hline O que é ambliopia ${ }^{4}$ & 27 & 81,8 & 8 & 100,0 & 5 & 83,3 & 11 & 78,6 \\
\hline Total & 33 & 100 & 8 & 100 & 6 & 100 & 14 & 100 \\
\hline
\end{tabular}

'Nåo responderam: 2 măes

${ }^{2}$ Nato responderam: 2 professores ou monitores de creche e 1 da saúde

${ }^{3}$ Náo respondeu: 1 professor au monitor de creche

4 Náo responderam: 3 professores ou monitores de creche

Indagados sobre o período de vida em que ocorre o desenvolvimento visual, $78,8 \%$ (26) dos professores e monitores de creche, $100 \%$ (8) do pessoal da saúde e do pessoal da Pastoral da Criança (6) e 50,0\% (7) das mães acertaram a resposta, qual seja, entre 0 a 7 anos, tal como é descrito por CRAWFORD (1982) e KARA-JOSÉ (1984).

O percentual de erro das mães, nesta questão, deve-se, provavelmente, à confusão entre $a$ idade em que se pode aplicar o primeiro teste quantitativo em crianças e a idade em que se completa 0 desenvolvimento visual; as mães demonstraram satisfação em terem 
conseguido aplicar o teste de "jögger hand"s, a ponto de levar provavelmente à referida confusão.

De qualquer forma, acredita-se ter atingido o objetivo de passar a noção do período no qual ocorre o desenvolvimento visual, período propício para atuar com ações preventivas (KARA-JOSÉ 1984). Levando em consideração que a maioria dos atores sociais jamais havia discutido conceitos básicos sobre saúde ocular e nenhum deles, à exceção do médico oftalmologista e de um professor, que haviam recebido ou participado de um projeto de saúde ocular, o resultado obtido pode ser considerado positivo.

Na segunda questão, referente à definição de acuidade visual, verificou-se que apenas $27,3 \%$ (9) dos professores e monitores de creche e $50,0 \%$ (4) do pessoal da Saúde acertaram a resposta. Por outro lado, $83,3 \%$ (5) do pessoal da Pastoral da Criança e $85,7 \%$ (12) das mães acertaram a resposta, aparentemente, um paradoxo, mas que pode estar sendo melhor compreendido, quando examinado à luz do lugar daqueles mergulhados na cotidianeidade, cuja preocupação primordial está voltada para questões concretas de subsistência, à valorização/ reconhecimento dos sentidos como meios essenciais para se relacionarem com o mundo $e$ nele poderem transitar com maior desenvoltura.

Quanto aos professores e monitores de creche que erraram, percebe-se que a maioria confundiu acuidade visual com cuidados dos olhos. Acredita-se que pode ter havido uma falha na construção da questão $e$, especificamente, da treinadora, que não explorou o tema

\footnotetext{
- Trata-se de teste aplicável em crianças de 3 a 5 anos de idade, em que a figura é uma mão, que vai diminuindo de tamanho gradativamente, similar à tabela de Snellen.
} 
acuidade visual, que nada mais era do que a medida da quantidade de visão. Este termo foi constantemente utilizado por professoras, constituindo, inclusive, um dos ítens da ficha de saúde ocular de cada criança, que era preenchido quando de seu atendimento, verbalizado por elas, quando se referiam e comentavam sobre a quantidade de visão de uma criança.

Em relação à terceira questão, referente à idade em que se pode verificar se uma criança enxerga ou não, 78,8\% (26) dos professores e monitores de creche, $50 \%$ (4) do pessoal da saúde e $83,3 \%$ (5) do pessoal da Pastoral da Criança e 100\% (14) das mães responderam de forma correta, ou seja, desde o nascimento da criança.

Com esse resultado, pode-se inferir que ocorreu um entendimento básico do assunto questionado, que seria: assim que a criança nasce, devem-se observar os seus olhos, numa tentativa de perceber se enxerga e, em caso de dúvida, levá-la ao serviço de saúde ou especialista no assunto, para avaliação. Nessa questão, vale observar que o fato de 0 pessoal de Saúde ter apresentado um índice de acerto menor que os demais grupos, pode ser atribuído à confusão entre idade de aplicação do teste (quantitativo) e momento da observação, uma vez que todos os que erraram, responderam que seria aos três anos de idade, o que está relacionado, provavelmente, à ação de saúde que competiria a eles no Projeto.

Para a questão sobre sinais e sintomas de problemas visuais, as respostas se distribuíram entre os diferentes grupos da seguinte forma: $97,0 \%$ (32) dos professores e monitores de creche, $100 \%$ (8) do pessoal da saúde, $100 \%$ (6) do pessoal da Pastoral da Criança e 100\% (14) das 
mães acertaram a resposta, sugerindo estarem aptos a observarem, minimamente, 0 aspecto ocular externo das crianças.

Quando se abordou a questão da ambliopia, um termo técnico e pouco familiar até para o pessoal da saúde, como relatou SPERANDIO, 1999, em seu estudo com profissionais da saúde, em Campinas, os resultados encontrados para esta questão foram os seguintes: cerca de $81,8 \%$ (27) dos professores e monitores de creche, $100 \%$ (8) do pessoal da saúde, $83,3 \%$ (5) do pessoal da Pastoral da Criança e 78,6 \% (11) das mães acertaram a resposta. Grande parte das pessoas respondeu de forma mais simples sobre a definição de ambliopia: "um olho preguiçoso ou os dois".

Este fato vem revelar que é viável trabalhar com conhecimentos que, muitas vezes, ficam enclausurados na universidade ou mesmo, como um saber específico de determinados técnicos da saúde, dificultando outros atores sociais a ele terem acesso, dependendo da disponibilidade de quem aplica.

Vale destacar, neste momento, que os conhecimentos básicos específicos, trabalhados durante os treinamentos, foram assimilados pela maioria dos atores sociais, independentemente de seu grau de escolaridade ou de seu lugar na sociedade.

Uma outra maneira, pela qual se procurou identificar os conhecimentos adquiridos nos treinamentos, sobre saúde ocular, consistiu em elaborar uma pergunta aberta (discursiva), de caráter qualitativo, que permitisse apreender e desvelar os significados associados à situação de cuidados/atenção para com a saúde visual das crianças. 
Quando perguntado aos professores: "Em que situação a(o) Sra.(Sr.) acha que deve cuidar dos olhos da criança?", eles responderam, de modo geral, estarem atentos, em posição de alerta com relação à saúde visual das crianças.

"Sempre, em qualquer situação, prevenindo e orientando quanto aos cuidados em geral".

"Sempre, nos hábitos de higiene, postura, nos momentos de estudo, lazer, etc."

"A todo o momento, sempre observando para ver se não está prejudicando sua visão".

"Todos os dias, observando os olhos, alertando a criança a certos perigos".

"Constantemente, pois a qualquer movimento ou determinadas situações pode haver um fator que seja prejudicial".

Boa parte deles associou a situação do cuidado dos olhos da criança com o momento mais adequado para desenvolver ações de promoção $e$ prevenção em saúde ocular:

"Desde que a criança nasce e mantendo um acompanhamento sempre que necessário".

"Desde o nascimento".

"A partir do seu nascimento".

Alguns professores identificaram a situação ideal do cuidado com os olhos da criança à presença de algum sinal ou sintoma, direcionando o olhar para o lado clínico da doença:

"Quando apresentar algum tipo de sinais ou sintomas, como queixas, dor de cabeça, dor nos olhos, coceira, vermelhão nos olhos". 
"Quando apresenta algum sintoma ou mesmo que não apresente problemas aparentes".

"Quando a criança apresentar problemas de visão".

Alguns professores referiram a necessidade de encaminhamento ao oftalmologista como uma indicação de rotina, significando uma atitude preventiva frente à saúde ocular:

"Desde a higiene, observação e consultas periódicas ao oftalmologista. No período de 0 a 7 anos da criança".

"Em todas as situações e procurar o médico. Desde o nascimento".

Em relação às respostas dadas pelo pessoal da saúde, o cuidado com os olhos da criança é percebido sob diferentes perspectivas da saúde e da doença:

"Em todas as situações, desde a higiene adequada, como a consulta com o especialistd".

"Rotina, a partir dos 3 anos, dependendo do caso, desde o nascimento".

"A partir de $O$ a 7 anos, isto é, de acordo com o problema de cada criançd".

"Desde que apareçam qualquer sinais ou sintomas de que a criança está com problemas nos olhos".

O grupo da Pastoral da Criança, em sua maioria, se referiu a situações em que algum problema ou sintoma é identificado, como o momento para cuidar dos olhos da criança: 
"Quando a criança estiver sentindo algum problema/sintoma nos olhos".

Por outro lado, dois outros integrantes da Pastoral identificaram a necessidade de cuidado, desde pequeno.

"A partir de um ano de idade".

"Desde pequeno, porque se passou da idade, pode não ter mais resultado".

As mães dividiram as situações do cuidado com os olhos das crianças em duas vertentes: umas que apontaram em todas situações, e outras somente quando a criança apresentar algum tipo de problema visucl. Aquelas que afirmaram "em todas as situações", referem-se à necessidade de levar ao oftalmologista e tomar medidas preventivas com relação à saúde ocular:

"Desde sempre".

"Fazer o teste sempre".

"Sempre levar ao oculista, e fazer alguma prevenção e cuidar melhor em casa".

"Sempre, levar ao oculista, lavar as mãos, não coçar os olhos".

"Acho que devemos passar nossos filhos sempre pelo oftalmologista, porque a televisão e vídeo força muito a vista".

"Quando a criança começa a apresentar qualquer tipo de problemas visuais"

Em suma, pode-se notar que o período ideal para cuidados com relação à saúde visual da criança, pelos relatos dos distintos ctores sociais envolvidos no projeto de promoção da saúde ocular, expressa duas 
principais vertentes do processo saúde-doença: de um lado, a ótica da doença e de outro, a da saúde.

Um outro objetivo proposto neste estudo foi desvelar os significados de saúde ocular, promoção da saúde ocular e prevençčo de problemas visuais, segundo a percepção dos atores sociais. Para tanto, procedeu-se, de acordo com a metodologia qualitativa proposta, à descrição das categorias eleitas, a partir da leitura e releitura dos discursos dos atores sociais.

Apresentam-se, a seguir, as percepções dos atores sociais sobre os temas elencados:

\section{Percepção sobre saúde ocular}

Em face da pergunta: $O$ que vem à sua cabeça quando se pensa em saúde ocular? Os professores, em sua maioria, responderam estar associada aos cuidados e prevenção:

"Ter cuidados com os olhos/visão".

"Cuidados com os olhos, enxergar bem".

"Preveni-lo contra as doenças que possa afetar os olhos".

"Ter uma visão saudável, sem nenhum problema ou estar em tratamento, cuidando, caso tenha algum problema. Estar enxergando bem".

Outros qualificaram a forma de cuidado com relação à saúde ocular:

"Ter cuidado com os olhos, como higiene, consulta oftalmológica, para conservar a boa visão". 
Um outro grupo de professores relacionou a saúde ocular com o próprio Projeto desenvolvido no Município, em termos de reconhecer sua relevância e a importância da consciência do saber:

"Antes do Projeto, pessoas sem problemas de visão, com o projeto, percebi a necessidade de esclarecimentos sobre a Promoção e Prevenção da saúde ocular".

Um outro relacionou a saúde ocular com a idéia de felicidade, de coisas belas:

"Felicidades com 100\% de visão".

"Ver as coisas belas"

"Enxergar/ver o mundo".

É interessante observar que alguns professores vincularam c saúde ocular com a idéia de ajuda, provavelmente, em decorrência da idéia trabalhada no Projeto, qual seja, a de multiplicarem os conhecimentos apreendidos e aplicarem os testes visuais na população infantil:

"Tentar fazer o que posso para ajudar quem precisa".

"Tentar ajudar o individuo na questão da saúde ocular".

Cabe ressaltar que a concepção de saúde ocular, para grande parte dos professores, foi vista dentro da perspectiva médica (doença), embora alguns a vissem mais na direção da saúde, entendida como ausência de doença:

"É a saúde dos olhos, ou seja, prevenir contra alguns tipos de doenças que podem refletir problemas futuros". 
"A saúde ocular sendo que os olhos se apresenta saudável, sem nenhum sinal ou sintomas".

O grupo de professores respondeu mais do lugar de um agente profissional, que tem responsabilidade na vigilância da saúde ocular de seus alunos, ou seja, mostrou a relação desta com o seu papel profissional.

Quanto ao pessoal da saúde (8), este manifestou, explicitamente, o reconhecimento da importância da saúde ocular $e$, como decorrência, a relevância do maior conhecimento em relação a esse aspecto. A saúde ocular é percebida, associada aos níveis de prevenção e tratamento, como pode ser observada:

"Tomar mais conhecimentos sobre a saúde dos olhos, tanto prevenindo como também tratando alguns sintomas que não damos muita importância e que pode nos trazer conseqüências sérias".

"Tomar mais conhecimento sobre a saúde dos olhos que são muito valiosos".

"Levar o conhecimento sobre a saúde dos olhos, como tratamento $e$ prevenção.

"É saber mais sobre os nossos olhos (visão), ensinando a se prevenir e tratar os problemas".

Um representante do pessoal de saúde manifestou a importância da saúde ocular, como decorrência do treinamento realizado pelo Projeto.

"Estava bastante esquecido sobre a saúde ocular, particularmente eu mesmo só tomei consciência com o treinamento". 
Um outro relacionou a prevenção ao processo de trabalho em saúde: "Prevenção - trabalho em equipe para a prevenção".

O médico, por sua vez, associou diretamente a saúde ocular com sua profissão, revelando associar com o que faz, ou seja, assistência médica voltada aos aspectos curativos:

"Minha profissão"

O grupo da Saúde, de modo geral, associou a saúde ocular, a partir do lugar, da posição de agente de saúde frente à realidade de saúde, explicitando a importância da educação em saúde, como de sua responsabilidade, a fim de permitir o acesso da população a esses conhecimentos.

Em relação ao pessoal da Pastoral da Criança, observa-se que a saúde ocular está associada à imagem positiva, visão boa, perfeita, de viver bem:

"Uma visão boa".

"Ter uma visão perfeita, cuidar da proteção dos olhos".

"Viver bem, carinho para dar as crianças e amor por este trabalho".

Um outro aspecto, apontado pelo pessoal da Pastoral, refere-se à concepção do direito:

"Que todos nós devemos e temos os nossos direitos em relaçio nâo só a saúde ocular, mas a outras também" 
Relacionada às ações desenvolvidas pelo Projeto, um dos participantes explicitou da seguinte forma:

"Aprendi muito com esse curso".

Um dos atores da Pastoral da Criança, ao se expressar sobre o significado da saúde ocular para ele, o fez, segundo a postura de um agente de saúde:

"Cuidar da visão das pessoas para que possa preservar a visâo".

O grupo de mães, por sua vez, referiu-se ao significado da saúde ocular para suas vidas, isto é, colocando a visão, (o ato de enxergar) como a janela para um mundo melhor, reconhecendo a importância da prevenção, vista como sinônimo do Projeto. Percebe-se o destaque que este grupo deu à importância da visão no contexto de vida e saúde.

"Enxergar, coisa boa".

"É vida, pessoas sadias"

"Poder ver as coisas boas. Poder ver tudo ao nosso redor".

"Melhorar a vida da gente".

"Penso que está tudo bem na família".

"Ter uma boa visão em todos os sentidos e sentir-se bem".

Um outro grupo de mães associou a saúde ocular com a idéia de cuidado, de prevenção, de tratamento:

"Cuidar da visão". 
"Éa prevenção, é o teste visual desde quando a criança nasce".

"Melhorar a saúde ocular, prevenção, teste desde que a criança nasce".

"Penso em tratamento da vista".

Para algumas mães, saúde ocular esteve associada com o Projeto Ver e Viver:

"Prevenção da visão e do Projeto Ver e Viver, que é muito bum".

Para uma mãe, a saúde ocular esteve relacionada com a situação de saúde ocular de seu próprio filho:

"Muito preocupante, pois tenho um filho que tem menos de $20 \%$ de visão".

\section{Percepção sobre promoção da saúde ocular}

Para quase um terço dos professores, a promoção da saúde ocular está vinculada ao papel de um agente de intervenção, com o objetivo de realizar/concretizar alguma ação para a melhoria da saúde ocular:

"Ação de nossa parte para a melhoria da saúde ocular".

"Estar divulgando ação para melhorar a saúde ocular".

"Todas as açôes, intervenções que permitem a busca de uma qualidade de visão".

Uma outra forma de o agente intervir na realidade, apontada por professores, diz respeito à tarefa de esclarecimento, de conscientização 
quanto à importância da saúde ocular, do cuidado com os olhos e do problema da visão, junto à população de modo geral, à comunidade escolar, a todos os profissionais e às pessoas:

"Esclarecimento para que cada indivíduo cuide de seus olhos, envolvendo a qualidade de vida para que possa ter sempre una boa visão".

"Esclarecimento para que cada um cuide de seus olhos, para ter sempre uma boa visão".

"Conscientizar todos da importância da visão".

"Dar noções a toda comunidade escolar da importância em cuıdar da visão".

"Éa conscientização e educação da população, quanto ao problema da visão".

"Conscientização de todos os profissionais".

"Esclarecer as pessoas a respeito da saúde como se fazer hábitos para se ter uma saúde cada vez melhor".

Um fator importante, apontado por alguns professores, quanto à promoção da saúde ocular, refere-se ao significado de "criar condições para que o indivíduo possa controlar sua própria saúde", denotando ter assimilado a concepção de promoção, segundo o entendimento de LABONTE (1994 e 1998).

Em outras palavras, a concepção de promoção da saíde compreende criar mecanismos mais enraizados na direção do controle social. Parafraseando um autor, é ensinar a pescar e não dar o peixe. 
"Criar condições para que as pessoas tenham uma boa qualiciade de vida e possam controlar sua própria saúde".

Por sua vez, professores, ao explicitarem a criação de condiçôes para a melhoria da saúde ocular, relacionam a promoção à qualidade de vida, componente fundamental apontado por especialistas da área:

"Criar condições para uma boa qualidade de vida, um trabulho em conjunto para o bem estar das pessoas".

"Criar condições para que as pessoas tenham uma boa qualiciade de vida".

"Capacidade de ter uma visão saudável, onde possa ter una boa qualidade de vida para obter uma boa saúde ocular"

Um fator importante, também considerado por esses atores sociais, refere-se ao procedimento, que foi realçado também pelo Proje“o, qual seja, a necessidade do encaminhamento para o médico oftalmologista:

"Criar condiçóes para que as pessoas tenham uma boa qualic'ade de vida e que controlam a sua saúde, buscando sempre um médicc para o bem estar da família."

"Criar condições para que as pessoas tenham uma boa qualiciade de vida, controlar a sua própria saúde, buscando sempre um bom médico."

Um outro ponto importante, ressaltado por alguns professores, foi a observação, entendido como um olhar mais atento, mais de alenta em relação à saúde ocular das crianças, principalmente, e das pessoas, de modo geral. Foi constante nas falas dos professores, a ênfase dada quanto às ações de encaminhamento ao oftalmologista. Assim têm-se: 
"Procurar observar não só na sua casa, mas também do seu bairro, dos seus amigos em geral; se notar alguma diferença nos olhos, orientá-los a procurar o oftalmologista".

"Observar as crianças e encaminhar, procurar orientar as pessoas".

"Observação das crianças e pessoas do próprio convivio e alertar sobre alguns fatores evidentes (em relação aos olhos) e orientá-los a procurar especialista no assunto".

"Como professora e cidadã, observar nas pessoas conhecidas se há algum sintoma ou sinais relacionadas à saúde ocular e orieritá-la a procurar um oftalmologista mais rápido possivel".

A promoção da saúde envolve, também, para alguns professores, a questão dos direitos e, para tanto, recorrem à importância de políticas públicas consoantes com o interesse do cidadão:

"Que o cidadão seja beneficiado em seus direitos através de políticas públicas com verdadeiro interesse no ser humano".

O significado da promoção da saúde ocular, para determinados professores, como não poderia deixar de ser, está relacionada com o desenvolvimento do Projeto Ver e Viver, tais como: desenvolvimento de parcerias, a multi-institucionalidade e, até, a oferta de óculos às crianças:

"Órgãos públicos desenvolvendo ações visando a saúde ocular em parceria com ONGs".

"Trabalho gratuito de consultas e oferta de óculos e tratamentos necessários". 
A divulgação e seus meios foram destacadas por professores, como forma de promoção da saúde ocular.

"Divulgação, palestras, programas, projetos direcionados à saúde ocular".

"Divulgação do Projeto, envolvendo toda a população, envilvendo qualidade de vida, moradia, alimentação, higiene e saúde".

Quanto ao pessoal da saúde, a partir de seus relatos, a promoção envolve a educação, a orientação sobre a saúde ocular, expressando a imagem que faz de seu papel pedagógico, enquanto agente de saúde:

"Educação em saúde. O profissional da saúde deve trabalhar junto a comunidade para ampliar os conhecimentos".

"Falar sobre a saúde ocular".

"Falar sobre a saúde ocular, fazer propaganda para que se faça um alerta geral".

"Alertar os pacientes sobre a saúde ocular".

Em consonância com a educação, um pessoal da saúde explicita a necessidade de divulgação:

"Divulgar, esclarecer as pessoas sobre os cuidados e tratamento que são oferecidos, pois é melhor prevenir do que depois tratar".

Aliado ao ensino-aprendizagem, dois atores da área da saúde enfatizam o processo de capacitação: 
"É um processo de capacitação das pessoas para aumentar o controle sobre sua saúde e melhorá-la. Prevenir e evitar determinados danos para a saúde".

Em síntese, o pessoal de saúde, ao se colocar na posição de agente de intervenção, ressalta seu papel de educador na questão da promoção da saúde. E, finalizando a parte referente à importância da saúde ocular, relatada pelo grupo do pessoal de saúde, cita-se a fala de um deles:

(A Promoção da Saúde Ocular) "deveria existir em todas as Secretarias da Saúde".

Quanto ao grupo da Pastoral da Criança, a promoção da saúde ocular esteve associada à sua vocação missionária, qual seja, a de ajuda ao próximo.

"Ajudar aqueles que não recebem os atendimentos necessárics".

"Ajudar pessoas carentes".

Por sua vez, um ator social da Pastoral da Criança alia seu trabalho ao do Projeto Ver e Viver, explicitando sua atenção à população excluída:

"Penso que muitas pessoas carentes não tem condições financeiras, condições de ir até a um atendente e junto com a pastoral pudemos levar esse Projeto a outros lugares".

Outros salientam as formas de prevenção da saúde ocular, associadas à promoção da saúde, tais como a educação e a aplicação de testes:

"Fazer testes antes de sentir alguns sintomas".

"Ensinar as crianças a usar as coisas certas para os olhos". 
Em relação às falas das mães, a promoção da saúde ocular foi associada, muitas vezes, à idéia de divulgação, de estimulação bem no sentido usual do termo. Assim,

"Divulgação da saúde ocular"

"Penso que deveria ser mais divulgado pela prefeitura".

Por outro lado, a promoção da saúde, para outras mães, é confundida com a idéia de cuidado, de prevenção:

"Cuidar dos olhos".

"Procura um oculista e se prevenir".

"Ter conhecimento do nosso corpo para podermos prevenir"

"Prevenir a saúde ocular".

"A prevenção do teste visual, lavar as mãos sempre que for ao banheiro, cortar as unhas, não coçar os olhos, não pingar coilírio sem a orientação do oculista".

Uma mãe relacionou a promoção da saúde ocular com o saber fazer, com a ação a ser concretizada:

"O melhor para as pessoas ver melhor, fazer cursos, fayer uma atividade".

Duas outras mães articularam, em suas falas, a promoção da saúde com o seu contexto familiar:

"Penso que está tudo bem na familia".

"Que tinha que levar meu filho no médico do posto ou qualquer hospital público pois não tenho como tratá-lo". 


\section{Percepção sobre a prevenção de problemas visuais}

"Prevenir é melhor que remediar".

A prevenção de problemas visuais é vista por professores como uma multiplicidade de ações de natureza basicamente educativa, dirigidas o crianças, aos pais e à população de modo geral, expressando, mais uma vez, o papel de agentes de mudança na melhoria da saúde ocular:

"É um conjunto de ações, nas quais a finalidade é evitar problemas e detectar problemas precocemente".

"Conscientização das pessoas a fim de evitar os problemas com a visão, tomando os cuidados necessários e adequados".

"Conscientização dos cuidados da visão que cada indivíduo tem que ter com os olhos".

"Conscientização dos cuidados com os órgãos da visão, realização de testes para detectar possíveis problemas".

Muitos dos professores detalharam a orientação sobre a prevenção em saúde ocular, expressando os conhecimentos recebidos no treinamento:

"É orientá-las sobre a higiene, não colocar as mãos sujas nos olhos, com areia, tomar cuidado com objetos pontiagudos, tesoura. lápis e não coçar os olhos com as mãos".

"Orientar as pessoas quanto a higiene, contato com as mãos com os olhos, objetos pontiagudos, etc."

"Conscientização dos cuidados que se deve ter com os olhos, garantindo uma boa visão (não colocar mãos sujas, cuidaaos com objetos pontiagudos, etc.), realização de testes para detectar possiveis problemas". 
"Orientá-las sobre a higiene, não colocar as mãos sujas nos olhos, etc.".

"Aplicação dos testes e observações feitas nas escolas, creches $e$ em comunidades com $o$ auxílio de grupos de apoio a saúde e o encaminhamento quando necessário ao profissional".

Outros professores adicionaram à orientação, encaminhameritos aos serviços de saúde, particularmente ao médico oftalmologista.

"Orientar as pessoas e as crianças quanto a higiene dos olhos, a sinais evidentes nos olhos entre outros fatores, a procurarem um profissional da área, caso haja algum sintoma nos olhos".

"Orientar e encaminhar para o oftalmologista para avaíaçăo e salientar com trabalhos adequados para os possíveis problemas que possam surgir".

"A comunidade orientada terá condições de prevenir problemas futuros: ida constante ao oftalmologista, cuidados em casa, etc".

Ao abordar a questão da prevenção de problemas visuais, um professor alertou para a necessidade da continuação do projeto, salientando sua importância:

"Após assimilado o conhecimento a respeito da visão, ternos que prosseguir com o projeto para prevenir alguns fatores que venham a causar algum dano visual".

Cerca de um quarto dos professores relacionou a preverição de problemas visuais com a noção de cuidado com os olhos:

"Cuidados com os olhos".

"Tomar conhecimento dos cuidados que devemos ter com os s/hos". 
"Tomar os cuidados necessários para não vir a ter problemas, nos instruirmos a respeito das maneiras de prevenção".

"Cuidados que devemos ter com os olhos para evitar problemas visuais".

"Cuidar para que não haja problemas na visão, manter uma boa higiene, etc.".

A prevenção de problemas visuais é associada, também, com "bons hábitos" das pessoas:

"Incentivar os bons hábitos".

"Ter bons hábitos".

Ao abordar a questão da prevenção de problemas, um professor relacionou-a com o período inicial da prevenção:

"Temos que ter desde o início da vida já começa no pré-natal e assim por diante, onde todos tem que direito ao médico para prevenir os problemas visuais".

Ao finalizar o relato das falas dos professores com relação à questão da prevenção de problemas visuais, enfatiza-se a forma como eles associaram com a noção do agir/ação, expressando, mais uma vez, o papel internalizado de agente de mudança:

"A nossa ação para evitar possíveis problemas visuais".

"Ações e atos para se evitar problemas com a saúde visual".

"Ações que se colocam em atos para evitar a saúde ocular". 
Para o pessoal da Saúde, a prevenção de problemas visuais esteve associada, também, com a noção do agir/atuar, significando o devir do agente de saúde, no sentido mais abrangente do termo:

"O que deveria ser realizado para evitar problemas posteriores".

"Atuar nas ações específicas para evitar determinados danos para a saúde".

Um pessoal da Saúde associou a noção de prevenção com c período ideal de atuação e de encaminhamento ao oftalmologista, como atividade de prevenção de saúde ocular:

"Que desde pequeno, as pessoas deveriam levar as crianças para uma consulta com o oftalmologista para que, se houver algum problema, prevenir e tratar antes de se tornar mais grave".

Outras pessoas do grupo da Saúde enfatizaram a necessidade de se contar com um pessoal treinado em prevenção de problemas visuais em todos os centros de saúde:

"Ter em todos os centros de saúde, pessoas treinadas".

"Ter em todos os centros de saúde, profissionais treinado: ou uma equipe para fazer este tipo de trabalho".

Um pessoal da Saúde focalizou a atenção na aplicação dos testes de acuidade visual:

"Mesmo sem sinais ou sintomas, fazer testes de acuidade visual, para que se surgir algum problema possa ser tratado no início chegando até a cura". 
"Fazer o teste, mesmo sem sintomas, caso apresente algum problema, pode ter tratamento mais cedo".

Quanto ao pessoal da Pastoral da Criança, a prevenção de problemas visuais está relacionada com a noção de ajuda, de cuidado com os olhos. Para tanto, explicitam sua forma de prevenção:

"Cuidar dos olhos, usar proteção nos olhos, tomar cuidcdo com objetos pontiagudos".

"Que você está prevenindo os problemas visuais da pessoa".

"Fazer todos os testes de acordo com a idade da criança".

Por sua vez, um dos atores sociais da Pastoral aponta os benefícios da prevenção:

"Que com isso muitas pessoas que estão com problemas visuais tem condiçôes de ver melhor e prevenir algum problema mais grave na vista. Pois é lindo ver".

Em relação às falas das mães, a prevenção de problemas visuais está ligada à importância de ver o mundo:

"Ver que a visão é uma coisa que temos que curtir".

Algumas mães associaram a prevenção com a necessidade $e$ a importância de se ter maior conhecimento:

"A gente ter um grupo de pessoas que ajuda a informar meltior".

"Ter conhecimento para prevenir e para saber se tenl algum problema".

"Que os pais tenham mais conhecimento para a prevenção visual". 
"Eu acho que as pessoas deveria ter bem mais conhecimento sobre os problemas visuais e ajudar uns aos outros sobre a prevenção visual".

Um outro aspecto, destacado por algumas mães, foi a importância de se aplicar o teste de acuidade visual, como forma de prevenção:

"Fazer um teste e procurar notar alguma diferença na criança".

"Teste de visão, não cair cloro nos olhos"

Ao se abordar a questão da prevenção, um grupo de mães se reportou à necessidade de se encaminhar a criança ao oculista, utilizando-se a linguagem empregada por elas. Ao mesmo tempo, scilientou os cuidados a serem tomados para a prevenção da saúde ocular:

"A gente deve ir ao oculista uma vez por ano, tomar cuidado com produtos químicos, cuidado com as unhas compridas, cuidado com lápis. Procura um oculista e se prevenir".

Uma mãe associou a idéia de prevenção com os cuidados o serem tomados com seus filhos. E uma outra relacionou com a mesma lćgica de raciocínio de outro exame preventivo:

"Sempre cuidar dos outros filhos pois aquele que tem problema caiu e ficou assim, cuidei cedo e não dei mais remédio".

"Quando faz exames como papanicolau".

Em suma, o que se pode depreender, a partir das falas dos atores sociais, é que as noções sobre saúde ocular, promoção da saúde ocular e prevenção dos problemas visuais, estão intimamente relacionadas com a participação desses atores no projeto, em relação ao que aprenderam, 
principalmente relacionadas à importância da saúde ocular e à capacitação para a aplicação dos testes de acuidade visual e à forma como desenvolveram suas ações/atividades, de forma educativa e colaborativa.

A seguir, são descritas, no quadro 7, as ações/atividades listadas por atores sociais, relativas às suas participações no Projeto Ver e Viver 
Quadro 7 - Participação em ações/atividades do Projeto Ver e Viver, segundo o grupo de atores sociais. Morungaba, 2000.

\begin{tabular}{|c|c|c|c|c|c|c|c|c|}
\hline Ações/atividades ${ }^{\star}$ & $\begin{array}{l}\text { Profe } \\
\text { s }\end{array}$ & ssore & & aúde & Past & roral & Mó & íes \\
\hline $\begin{array}{l}\text { Conscientização dos pais e alunos } \\
\text { sobre a importância da saúde ocular }\end{array}$ & $\begin{array}{c}N^{\circ} \\
7\end{array}$ & $\begin{array}{c}\% \\
21,2\end{array}$ & $\mathrm{~N}^{\circ}$ & & & $\%$ & $\mathrm{~N}^{\circ}$ & $\begin{array}{l}{ }^{2} \\
-\end{array}$ \\
\hline Treinamento & 18 & 54,5 & 6 & 75,0 & 2 & 33,3 & 6 & 42,8 \\
\hline Triagem & 23 & 69,7 & 5 & 62,5 & 6 & 100 & 6 & 42,8 \\
\hline $\begin{array}{l}\text { Palestras e divulgação para outros } \\
\text { profissionais }\end{array}$ & 2 & 6,1 & & - & & - & & - \\
\hline Encaminhamentos & 11 & 33,3 & 1 & 12,5 & & - & & - \\
\hline $\begin{array}{l}\text { Reunião clos prof, grupo de } \\
\text { trabalho,pais }\end{array}$ & 16 & 48,5 & & - & 1 & 16,7 & & - \\
\hline $\begin{array}{l}\text { Contato permanente com a } \\
\text { coordenadora }\end{array}$ & 1 & 3,0 & & - & & - & & - \\
\hline Confecção do material & 1 & 3,0 & & - & & - & & - \\
\hline $\begin{array}{l}\text { Reconhecimento das partes dos olhos } \\
\text { e sua importância através de jogos } \\
\text { pedagógicos (massinha, teatro, } \\
\text { maquete, musicas, desenhos) }\end{array}$ & 32 & 97,0 & & - & & - & & - \\
\hline Exposição & 10 & 30,3 & & - & & - & & - \\
\hline Projeto na sala de aula & 8 & 24,2 & & - & & - & & - \\
\hline Entrevista para TV & 1 & 3,0 & & - & & - & & - \\
\hline Cartazes & 3 & 9.1 & & - & & - & & - \\
\hline Médico Oftalmologista & & - & 1 & 12,5 & & - & & - \\
\hline Visita os sitios/bairros/crianças & & - & & - & 1 & 16,7 & & - \\
\hline Promoção da Saúde Ocular & & - & & - & & - & 1 & 7.1 \\
\hline Prevenção de Problemas Visuais & & - & & - & & - & 1 & 7,1 \\
\hline Jogos de treinamento & & - & & - & & - & 1 & 7,1 \\
\hline Opinião & & - & & - & & - & 1 & 7,1 \\
\hline Total & 33 & 100 & 8 & 100 & 6 & 100 & 14 & 100 \\
\hline
\end{tabular}

* As respostas foram múltiplas. 
As ações/atividades em que os professores participaram, de modo geral, estão relacionadas às atividades de ensino-aprendizagem:

"reconhecimento das partes dos olhos e sua importância através de jogos pedagógicos", "triagem", "reuniões com os professores/pais", "exposição", "encaminhamentos", "conscientização dos pais e alunos sobre a saúde ocular", etc.

Com base nessas respostas, pode-se notar que os professores participaram ativamente no desenvolvimento das propostas do Projeto. reproduzindo, criando formas de trabalhar o conhecimento básico de saúde ocular com as crianças e com os pais.

Com relação ao pessoal de saúde, a ação mais destacada por esse grupo foi a aplicação do teste de acuidade visual. O pessoal da Pastoral da Criança e as mães citaram, também, a aplicação do teste como uma das atividades mais desenvolvidas.

Em síntese, o que se pode destacar é que a participação dos atores sociais, explicitada em suas respostas, seguiu em duas direçŏes: as ações/atividades recebidas/ aprendidas $e$ aquelas que foram desenvolvidas por eles, destacando-se a orientação e a aplicação dos testes de acuidade visual.

Em continuação à descrição dos aspectos significativos da participação vivenciada no Projeto, segundo os atores sociais, apresentam-se. a seguir, as respostas à questão colocada no questionário, qual seja, "Conte para nós um fato que marcou muito c(a) Sr(a) em sua participação no Projeto Promoção da Saúde Ocular ". 
As respostas a essa pergunta são apresentadas em forma de quadro no anexo 21.

Diante dessa pergunta, professores relataram os marcos significativos associados à participação dos mesmos e da coordenadora, ressaltando o respeito humano (dela) e a união de todos os professores na consecução das atividades propostas.

Destaca-se a crítica que dirigiram ao pessoal da Saúde, que adotou uma atitude anti-ética para com os professores.

Uma outra dimensão apontada por professores foi sobre a criança/aluno, sujeito central de sua atenção, ressaltando a participação ativa das mesmas nas atividades desenvolvidas em aula, bem como o interesse demonstrado na aplicação dos testes de acuidade visual. Um outro grupo de respostas, relacionada à criança, foi a importância das medidas de intervenção na área da saúde ocular, por intermédio das quais, a criança começou a usar óculos e, consequientemente, "melhorouo seu rendimento escolar", "se desenvolveu na leitura e escrita", enfim, avançou em seu processo de aprendizagem.

Por outro lado, alguns professores expressaram a dificuldade de fazer o treinamento com crianças menores de três anos de idade. Neste sentido, faz-se necessário refletir sobre o redirecionamento do processo de ensino-aprendizagem, centralizando a atenção na criança em seu processo de desenvolvimento, possibilitando com o treinamento, capacitar os atores sociais a se relacionarem, a trabalharem com essa população infantil.

Um outro ponto destacado por professores foi a aplicação dos testes de acuidade visual, ressaltando a sua importância, a satisfação em 
sua aplicação, os diversos tipos de testes, de acordo com as idades das crianças, as formas de aplicação dos testes (brincadeiras e jogos).

Com relação às atitudes dos pais, os professores manifestaram o desapontamento diante da desconfiança deles para com o trabalho desenvolvido pelo professor, assim como o desinteresse dos pais pelos problemas detectados nos alunos.

Dois professores destacaram como marcos significativos a participação e o envolvimento no projeto, expressando a importância de sua contribuição na promoção, prevenção de problemas visuais em crianças.

Com relação aos marcos de participação no Projeto, o pessoal de Saúde identificou como significativa a dificuldade de preparar crianças menores de três anos de idade para o teste. Um outro ponto crítico levantado por um deles foi a falta de funcionários disponiveis, sugerindo estar havendo o sobrepeso de mais uma atividade a ser desenvolvida pelo pessoal da saúde, sem a necessária redistribuição de tarefas e/ou ampliação no número de funcionários. Neste sentido, um trabalho como este, que aumentou a demanda em mais de 73 crianças (total de crianças com suspeita de problemas visuais), concretamente encaminhadas à unidade de saúde do Município, significou um aumento substancial, requerendo um plane jamento mais comprometido com a nova realidade.

Com relação aos voluntários da Pastoral, os marcos principais de participação aparecem associados à criança, no que se refere à dificuldade de trabalho com crianças menores de três anos, tônica acentuada também do pessoal da saúde. Os voluntários destacaram o trabalho que eles tiveram para com algumas crianças que apresentaram 
problemas visuais e que enfrentaram dificuldades para resolvê-los (encaminhamento ao serviço de saúde).

Um aspecto positivo, levantado por um pessoal da Pastoral, foi o profissionalismo da coordenadora na condução do Projeto, destacando sua atitude de respeito ao ser humano. A satisfação de ter aplicado os testes em crianças foi, também, apontado por um deles. $O$ envolvimento com o Projeto foi outro ponto destacado como marco significativo de participação.

Em relação às mães, elas manifestaram satisfação por terem aprendido e aplicado os testes em crianças. $O$ cuidado/atenção com as crianças e oncaminhamento e atendimento, foram destacados por 4 mães.

De modo geral, pode-se constatar que os atores sociais professores e monitores de creche, pessoal da Saúde, voluntários da Pastoral e mães - expressaram pontos positivos com relação à participação no Projeto, apesar de alguns deles expressarem dificuldades enfrentadas para o desenvolvimento do mesmo.

Descritas as ações/atividades desenvolvidas pelos atores sociais e apresentados os marcos significativos de participação, procedeu-se à análise dos tipos de participação, tendo como intenção, continuar apresentando os aspectos significativos de participação, vivenciada pelos atores sociais no processo de construção do projeto de promoção da saúde ocular e prevenção de problemas visuais do município em estudo.

Com base em anotações do diário de campo do pesquisador, nas respostas dadas pelos atores, a partir da aplicação do questionário e, na documentação fotográfica, passou-se ao trabalho de situar os atores 
sociais nas categorias propostas na metodologia, quais sejam, participação transformadora e participação instrumental.

Cabe, a esse respeito, fazer a observação de que não se trata de enquadrar o trabalho ou a forma de trabalhar do ator social dentro de uma dessas categorias, de forma absoluta, única, como um ser que atuasse sempre e unicamente dentro de cada uma delas; pelo contrário, é importante reconhecer o movimento, a tendência, partindo do pressuposto de que cada um de nós é, ao mesmo tempo, sujeito transformador e sujeito instrumental, isto é, a visão de mundo da sociedade não se organiza de forma dicotômica, linear, mecânica, uma vez que os homens agem na sociedade, na maioria das vezes, de forma contraditória, conflituosa.

Feita a ressalva, a análise da participação, a partir dessas categorias, deu-se, levando em conta como cada ator social, em sua singularidade, se comportou, de forma predominante, conforme uma delas, em um dado momento e em um determinado espaço social.

Outro pressuposto importante da análise proposta é a existência e a coexistência de ambos os tipos de participação na sociedade, à medida que os indivíduos atuam/agem de formas diversas, expressando, por vezes, diferenças entre o pensar e o agir, outras vezes, apresentando o pensar e o agir de forma coerente. Isto posto, esclarece-se que não se trata de fazer a crítica a nenhuma delas, ao contrário, tenta-se compreender os distintos tipos de participação, com o cuidado de não estar emitindo opiniões valorativas sobre elas.

Por outro lado, é preciso reconhecer o peso da sociedade sobre os indivíduos, quanto ao modo de pensar, sentir e agir, que expressam, em 
grande parte, a forma como se situam nas relações sociais, traduzidas existencialmente em desigualdades sociais. Em outras palavras, a sociedade em que se vive, tende a produzir e reproduzir as desigualdades sociais, que se manifestam em todas as esferas do pensar, do agir e do sentir.

Neste sentido, quer-se esclarecer que, ao se analisar a participação dos atores sociais, deve-se, necessariamente, levar em consideração esses pressupostos, uma vez que, não é apenas no nível da singularidade do indivíduo que se deve buscar a explicação, ou mesmo, de intervenção, mas também, no nível macro-estrutural da sociedade.

Em suma, a implicação do pressuposto ressaltado, para a análise da participação, é no sentido de direcioná-la sem se descuidar do contexto mais geral da sociedade em que ocorrem os distintos tipos de participação.

Assim, é na relação entre os níveis mais gerais da sociedade e o nível de cada um dos atores sociais é que se deve compreender esta questão. Em outras palavras, é neste movimento social que é possivel entender os tipos de participação como uma categoria fluida, passivel de mudanças.

Feitas essas considerações, procurou-se desvendar o processo de construção do Projeto de Promoção da Saúde Ocular e Preverção de problemas visuais no município de Morungaba, com ênfase na participação. a partir dos trabalhos desenvolvidos pelos atores sociais e a forma como o foram.

$\mathrm{Na}$ instância político-institucional municipal, destacaram-se dois atores, enquanto participantes na construção do Projeto: a Prefeita e a Diretora da Educação. A Prefeita abriu as portas do Município, 
permitindo que se desenvolvesse o Projeto: apresentou a pesquisadora aos Diretores de Educação e de Saúde, determinou-lhes que dessem todo o apoio de que o Projeto necessitasse, em termos de recursos humanos, espaço físico, recursos materiais e administrativos para a implementação do Projeto. Pelo lugar de poder que ocupa (poder de dispor recursos, prerrogativa legal), pela abertura dada, tornando factível o Projeto, colocando à disposição a máquina administrativa do Município, tornou-se um ator vital para a implantação do Projeto, que resultou em sua incorporação como parte da política pública de educação do Município. Neste sentido, sua participação foi decisiva, o que autoriza a situá-la na categoria de sujeito transformador.

A Diretora de Educação, por sua vez, desenvolveu ações de articulação e promoção do processo de construção do Projeto de Saúde Ocular em Morungaba, não apenas no nível político, mas também no nível técnico da formulação, escolha de alternativas e de execução das ações/atividades: participou de todos os momentos do trabalho: nos treinamentos, nas reuniões com os professores, com as mães, com representantes da Prefeitura e com a coordenação do Projeto. Atuou como coordenadora local do Projeto, seu papel foi de mediadora entre os distintos atores sociais acima arrolados, entre o nível político e o técnicoadministrativo e o operacional. ${ }^{10}$

Desenvolveu ações intra e inter-institucionais, articulando no nível local, todo o processo de trabalho na área da educação: promoveu reuniões com os professores da rede municipal, estadual e privada,

${ }^{10}$ Esta separação em níveis só teve a intenção de facilitar a leitura, pois entendemos a articulação intrínseca entre técnico e político, ou seja, que não existe uma ação desprovida da outra. 
enfatizando a relevância deste Projeto para as crianças e para o Município como um todo; com os professores municipais proporcionou momentos de reflexão durante o processo, para que eles tomassem consciência da importância da proposta contida no Projeto e dele se apropriassem, como um bem coletivo, criando condições favoráveis para a elaboração de um plano de trabalho para o município.

Ao lado disso, desenvolveu ações intra e inter-setoriais, envolvendo Educação, Saúde, Esportes e Lazer, ONG: articulação da educação, saúde e administração para compra de equipamento médico necessário; articulação com a Diretoria de Esporte e Lazer para o apoio e colaboração nos trabalhos de marketing e divulgação do Projeto, pela mídia; criou e viabilizou exposição na Casa da Cultura dos trabalhos desenvolvidos pelas crianças das escolas em parcerias com outros setores.

Demonstrou iniciativa na busca e obtenção de recursos para: confecção de manuais de Promoção da Saúde Ocular e de "gibi" sobre a mesma temática para serem distribuídos entre os atores sociais participantes, pais e crianças (Para este trabalho, envolveu o pessoal da computação que trabalhava na prefeitura); lanches nas reuniões com professores e mães; condução para a visita às escolas rurais; a compra de equipamento médico.

Desenvolveu atividades de parceria com as empresas locais.

Criou condições para a aprovação da lei modificada, que tornou obrigatória a realização de testes de acuidade visual nas crianças nas escolas, aumentando as possibilidades de continuidade das ações previstas pelo Projeto. 
Diante do exposto, depreende-se que a Diretora da Educação tomou para si a responsabilidade da construção do Projeto. Todo o esforço despendido por essa participante, o foi com garra, emoção e, como ela mesma se referiu, "com amor". No nível simbólico, o significado de participação no Projeto, para ela, representou a possibilidade de construção de um novo modo de viver coletivamente, em que a educação, saúde, esporte e lazer, e empresas, mostraram ter condições de trabalharem juntos, na busca direcionada a uma melhor qualidade de vida e de saúde para os habitantes do Município. Desta forma, esse ator teve, fez e tomou parte no processo de construção do Projeto de Saúde Ocular, crescendo em sua capacidade de liderança junto aos demais pares, na condição de um sujeito social transformador.

Em relação aos coordenadores pedagógicos das EMEIs e EMEF, esses, pelo lugar que ocupavam, atuaram como ponte entre a Coordenação, Diretoria da Educação e os executores das ações do Projeto, no caso, os professores que estavam sob sua coordenação. Esses atores sociais foram vitais para a fase da implementação: estimularam os professores para trabalharem na construção do projeto; criaram espaço para planejarem o trabalho em salas de aulas; criaram e apresentaram idéias para o desenvolvimento pedagógico e materiais a serem trabalhados com as crianças; elaboraram com os professores um questionário sobre a saúde visual para ser distribuído aos pais. Participaram ativamente em todas as reuniões. Um deles, por iniciativa própria, elaborou um livro de histórias sobre a saúde ocular e uma música para as crianças cantarem a respeito da importância dos olhos. Em suma, esses atores sociais 
estimularam a participação de professores e pais, de forma ativa $e$ criativa, influenciando para a ampliação do Projeto em questão.

Com relação à atuação dos diretores da rede pública e privada de ensino, um deles ampliou o projeto, em face da demanda do real, contemplando crianças até a quarta série (obteve a aprovação das coordenações e da Diretora da Educação), enquanto uma diretora da escola privada adaptou o projeto para ser desenvolvido em sala de aula, de acordo com a realidade da sua escola; elaborou junto com os professores, um teatro interativo de fantoches com os personagens criados pelo Projeto: criou uma outra peça teatral, com a participação apenas das crianças. Promoveu reuniões com professores e com os pais. Isto posto, a atuação desses atores, no âmbito de sua área de influência, criou espaços de participação para outros professores e pais dos alunos, representando para o Projeto, canais vitais de participação na fase de implementação de ações.

Do total de professores da rede municipal de ensino infantil e fundamental, 5 deles participaram ativamente na fase de implementação do Projeto: elaboraram um plano de atividades, em conjunto, para ser desenvolvido em salas de aula: promoveram reuniões com os pais para apresentação do Projeto; desenvolveram atividades educativas, utilizando material disponível: participaram ativamente na preparação da exposição de trabalhos produzidos pelas crianças; organizaram um teatro com os personagens criados pelo Projeto e, também, montaram urna peça teatral com as crianças: multiplicaram os conhecimentos entre professores e crianças; elaboraram cartazes para ficarem expostos em salas de aula. Na escola infantil, as professores, junto com as monitoras 
de creche, compuseram uma música com o conteúdo do Projeto: promoveram brincadeiras de pirata e rabo do burro com o objetivo de familiarizar as crianças com o uso do tampão; realizaram, com a ajuda das crianças, um painel do corpo humano com o objetivo de localizar os olhos no contexto; promoveram um painel da produção das crianças, com desenhos e trabalhos em massinha, e o afixaram no refeitório. Esses sujeitos, acima descritos, foram os que apresentaram uma participação transformadora, segundo a leitura da pesquisadora.

Os demais professores participaram do projeto, atuando de forma menos ativa, mais aderente, boa parte reproduzindo os conhecimentos adquiridos nos treinamentos e aplicando os testes de acuidade visual, tendendo mais para a participação instrumental.

Na área da Saúde, conforme a descrição anterior do processo, a participação, de modo geral, tendeu mais para uma participação instrumental, aderente, com pequeno número de participantes. Entretanto, não se pode igualar a participação de todos eles como se fosse um bloco homogêneo.

Nesse grupo há que se destacar o desempenho de uma auxiliar de enfermagem, durante o período em que trabalhou no Projeto, participou ativamente, triando crianças da comunidade em visitas domiciliares, particularmente aquelas que se encontravam fora da escola.

Empenhou-se em realizar retestes em crianças encaminhodas por escolas e creche, antes da consulta com o oftalmologista. Encarregou-se de preencher o caderno de registro e de experimentar armações de óculos nas crianças, bem como de encaminhá-las ao enfermeiro-chefe da 
unidade, responsável em levar os pedidos e as receitas para a fábrica de armações.

Nesse período, sua participação foi vital, considerando, principalmente, a iniciativa em realizar visitas domiciliares.

A assistente social da área da saúde participou do processo do trabalho, sugerindo que a auxiliar de enfermagem realizasse a triagem visual nas visitas domiciliares de rotina, principalmente para atingir crianças que estavam fora da escola: serviu de ponte entre a coordenação do Projeto e a coordenação da Pastoral da Criança, uma vez que esta ONG já mantinha estreito relacionamento com a comunidade. Foi a responsável pela inserção desse órgão não-governamental no Projeto $e$, nestes termos, sua participação foi importante.

Os demais membros da Saúde apresentaram uma tímida participação no processo, provavelmente, em decorrência da sobrecarga das tarefas de rotina e a forma como a Direção de Saúde se colocou em uma atitude de resistência frente ao processo proposto. Essa postura pode ser atribuída a diferentes razões que não cabe aqui estar imaginando, porém. certamente, prejudicou o envolvimento do pessoal da saúde.

Ao se propor um Projeto deste alcance, é necessário levar em consideração no planejamento, a capacidade real de atendimento da demanda, encaminhada pelos atores sociais, principalmente das escolas, pois afetará, sem dúvida, a rotina de trabalho desse pessoal. Ao mesmo tempo, é preciso reconhecer a necessidade de reiniciar um trabalho para o envolvimento desse pessoal e, desta feita, de uma forma que se-lhes apresente aceitável. 
Em relação ao pessoal da Pastoral da Criança, o seu coordenador, discutindo a possibilidade de envolvimento no Projeto, conseguiu a participação de todos os seus voluntários. Além de participar da execução da proposta do Projeto, mapeou os diferentes bairros carentes do município de Morungaba, principalmente da área rural, utilizando seu veículo como transporte para levar o grupo até os referidos bairros. Cedeu sua casa para a realização do trabalho com as crianças do seu bairro que não estavam matriculadas na escola, abriu espaço para que a triagem fosse realizada na escola do Brumado e, o que é mais relevante, resolveu adotar o trabalho de promoção da saúde ocular e prevenção de problemas visuais como mais uma ação de saúde da criança a integrar o programa de atuação da Pastoral da Criança.

Durante as visitas às famílias da zonal rural, ficou evidente a familiaridade e o carinho para com os moradores, tanto por parte do coordenador, como por parte dos voluntários. Esse fato é relevante, pois a aproximação entre o executor e a população-alvo, dentro da perspectiva de um trabalho de promoção da saúde, é vital. Tal interação propicia tornar visiveis problemas sociais outros: por exemplo, ao se perceber, nas visitas, crianças em idade escolar fora da escola, cria-se um fato demandante de respostas por parte do setor correspondente. $O$ grupo acabou adotando, daí em diante, esse procedimento como parte da rotina de trabalho da Pastoral da Criança.

Como se pôde observar na descrição do processo, a participação da Pastoral foi de extrema importância, possibilitando ampliar a cobertura, bem como a manter a continuação do Projeto de Promoção, garantindo atingir os grupos sociais excluídos, localizados sobretudo nas áreas rurais 
e periféricas do município. Além disso, possibilitou com este trabalho, articular-se com a Educação, no sentido de levar crianças às escolas.

Ressalta-se a participação de uma voluntária em todas as visitas a famílias da zona rural. Disponibilizou sua casa para uma das reuniões de avaliação do processo de trabalho ocorrido. Aproximava-se das crianças com carinho, pegando-as no colo, oferecendo balas, conversando com as mães, identificando problemas, apoiando-as.

Por essas razões, esses sujeitos sociais foram categorizados enquanto portadores de uma participação transformadora, predominantemente, na medida em que ampliaram sobremodo a cobertura de atendimento do Projeto, incorporaram a saúde ocular como uma das ações básicas de saúde da criança desenvolvidas pela Pastoral da Saúde. Além disso, partindo de uma $O \mathrm{Ng}$, articulou-se com a Educação como uma verdadeira parceira objetivando incluir crianças até então, excluidas da escola.

A grande mensagem deixada pelos integrantes da Pastoral da Criança em Morungaba, é que conhecer a realidade das pessoas/famílias envolve sentimentos, valores, como solidariedade, respeito, simplicidade, fundamentais para o desenvolvimento de um projeto social, ilustrando, concretamente, a relação de dupla mão entre sujeito e objeto.

Em relação às mães, apesar da dificuldade enfrentada para obter sua participação, conforme já descrito, uma apresentou uma atuação que se destacou: frequientou todas as reuniões, reproduzindo material, realizando triagem visual em crianças de sua vizinhança e parentes, sensibilizando outras mães para participarem dos treinamentos. 
Uma outra, embora não pertencendo à comunidade São Benedito, participou do treinamento com objetivo de estender este trabalho para seu bairro, especialmente dirigido às crianças sem escola.

O trabalho com mães possibilitou uma reflexão a respeito do caminho percorrido, da instituição para a comunidade, em que as mães se apresentaram como o grupo mais fragilizado, menos instrumentalizado para o processo participativo. Ao levar em conta o conceito de "empowerment" indaga-se: não teria sido diferente o resultado, se essas mães tivessem sido contempladas em sua necessidade de maior fortalecimento?

Em outras palavras, fica uma lição para esse tipo de trabalho social: é fundamental levar em conta as relações sociais locais, identificando grupos que se encontram excluídos do processo de cidadania e que requerem a criação de condições necessárias para seu engajamento de uma forma mais igualitária, para a constituição de novos atores.

O Projeto contou com a participação de outros atores sociais, alocados no setor da Educação e na Administração da Prefeitura, que colaboraram na implementação do Projeto, fornecendo apoio logístico: pessoal da informática (colaborou na produção do gibi sobre saúde ocular), serventes/merendeiras (prepararam lanches, cuidando das crianças), secretárias administrativas (digitaram documentos para 0 Projeto como: listas de crianças, bilhetes para os pais convocando para reuniões etc...), colocador de faixas; motorista (transportou o pessoal para zona rural para visitar as escolas), auxiliares administrativos (digitaram documentos na Prefeitura para enviar aos professores: comunicação de reuniões, organização da exposição dos trabalhos das 
crianças etc...), fotógrafo e filmador (registrou os momentos de trabalho das crianças) e telefonista.

Ao se descrever a participação dos atores sociais envolvidos no Projeto, notam-se níveis distintos de atuação, uns mais transformadores, mais ativos no sentido da sua construção, criando, inovando, ampliando os propósitos iniciais, outros reproduzindo, multiplicando as atividades propostas.

De início, um Projeto que teve características verticalizantes, "de cima para baixo", em que o nível político-institucional atuou de forma vital para sua construção, tornando-o factível e aceitável, durante sua implementação, passou a apresentar condições de deslocar esse foco para uma outra direção, a partir das ações/atividades que foram sendo adequadas à realidade local, durante o processo de treinamento, propiciando o envolvimento dos atores sociais, no sentido de tomar para si - Projeto, que foi sendo transformado, permitindo novas articulações, parcerias, caracterizando-o como uma construção mais coletiva, mais participativa e mais condizente com o perfil da Cidade.

Uma outra mudança percebida foi que este projeto, inicialmente esboçado e proposto por um agente externo, (de fora para dentro), foi se transformando, a ponto de inverter a direção, ou seja, de dentro para fora: um exemplo digno de nota foi a promulgação da lei, que tornou obrigatório o teste visual em todas as crianças de 0 a 8 anos pelas escolas públicas locais. Tendo como base essa prerrogativa legal e a vontade manifestada pelos atores sociais quanto à continucção do Projeto, pode ser tomada como evidência dessa inversão. 
Finalizando, ao se visualizar o processo como um todo, observa-se a transformação do comportamento de atores sociais operada ao longo do desenvolvimento do Projeto, de participação provocada, induzida para uma participação mais atuante, comprometida, e até inovadora, apontando, inclusive, para abertura de espaços e conquistas de ações e estratégias na direção de melhores condições de qualidade de vida. 


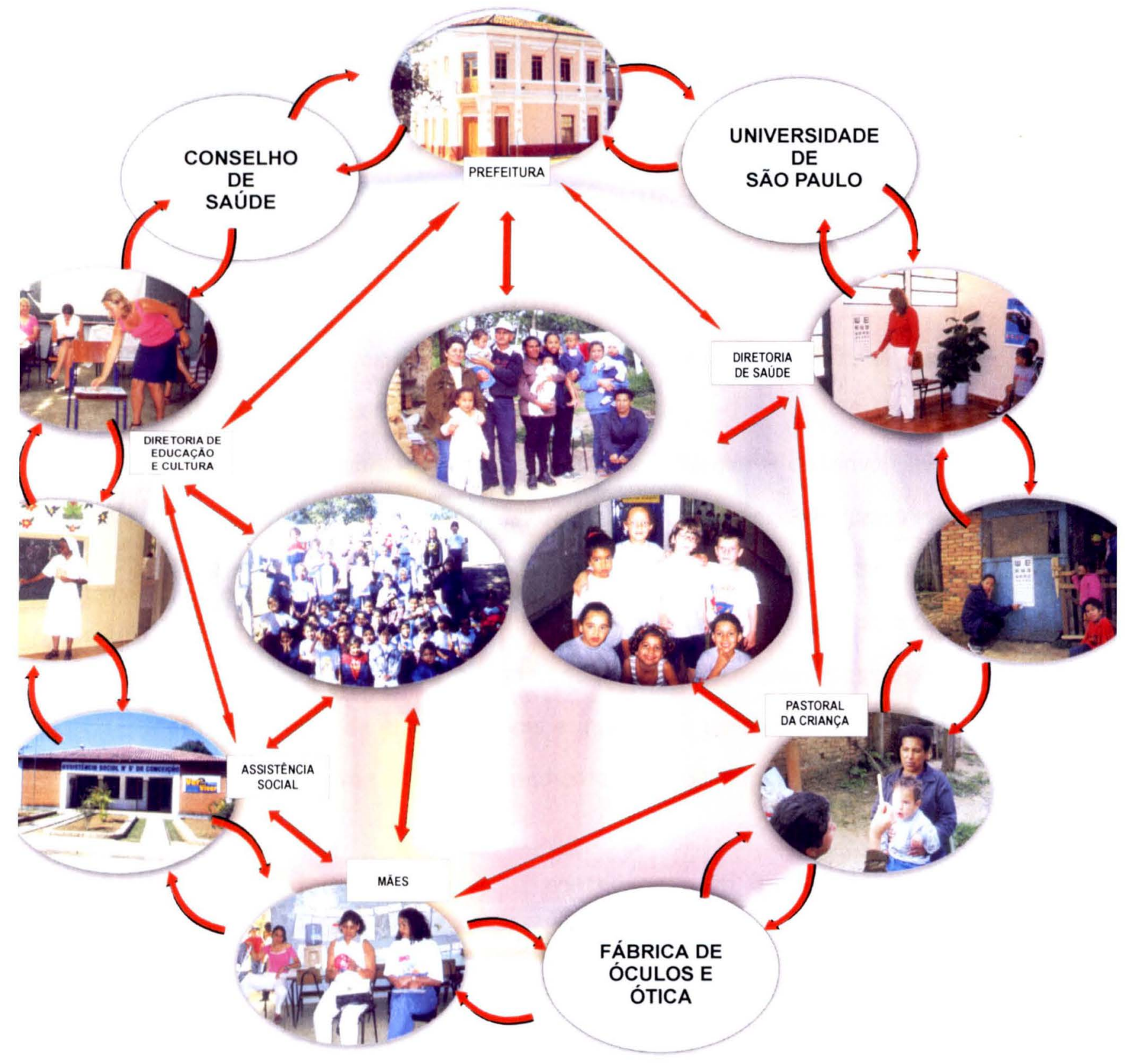

REDEDE COMUNICAÇÃO, PARCERIAS E INTERSETORIALIDADE CONSTRUÍDA PELOS ATORES SOCIAIS DE MORUNGABA-SP - 2000/2001 


\section{6 - CONSIDERAÇÕES FINAIS}

No processo de construção do Projeto de Promoção da Saúde Ocular e Prevenção de Problemas Visuais deste estudo foram envolvidas cerca de 1200 pessoas do Município de Morungaba.

Mais de 200 atores sociais dos diferentes setores da sociedade Educação, Saúde, Pastoral da Criança e Mães trabalharam para alcançar os objetivos do Projeto, no qual fizeram, transformaram, criaram $e$ ampliaram as propostas iniciais.

Em oito meses de trabalho, conseguiu-se atingir 981 crianças, sendo 722 de 0 a 7 anos e 259 maiores de 7 anos.

Atores sociais locais passaram a se articular - desenvolvimento de ações intersetoriais $e$ interinstitucionais, estabeleceram parcerias para se atingirem os objetivos básicos, e todo este processo foi sendo construído, a partir da sensibilização e criação de espaços para produção de novos saberes, neste caso, sobre saúde ocular, possibilitando o fortalecimento de grupos sociais e indivíduos para exercitarem a defesa de seus direitos sociais, mediante a participação no processo empowerment.

Um fato que pode vir a contribuir para a sustentabilidade do Projeto: a promulgação da lei de triagem visual em escolares, na faixa etária de 0 a 7 , conquista de atores sociais comprometidos com causas coletivas em benefício da população local.

Outra forma positiva, na direção acima apontada, foi o convite realizado pela nova Prefeita, no início do corrente ano para que a pesquisadora assessorasse a equipe local para dar continuidade às 
atividades desenvolvidas no ano anterior. A nova Prefeita, sensibilizada pelos próprios atores sociais que atuaram no ano anterior, retomou 0 processo, formalizando convite à pesquisadora para assessoria, assim como a representantes da Educação, Saúde e Pastoral da Criança para o re-encontro.

Nessa reunião, a Prefeita colocou, de antemão, seu desejo e de outros atores sociais, que o Projeto continuasse $e$, inclusive, fosse ampliado nas escolas, abrangendo alunos das quatro séries do ensino fundamental, além de crianças de menor idade.

Esse acontecimento foi o maior ganho qualitativo do Projeto, pois significou a apropriação do Projeto pelo Município, incorporando-se no projeto político municipal, expressando, assim, a vontade política de atores sociais locais.

Tudo isso vem confirmar a idéia inicial de que o desenvolvimento de projetos relevantes para uma dada população local, ainda que tendo, como pretexto, uma tarefa acadêmica, pode vir a significar o inicio de um processo em que os atores sociais locais assumem a posição de protagonistas, garantindo a continuidade do Projeto, com o compromisso de ampliação de horizontes, incorporando outras questões relevantes para a qualidade de vida dos moradores do Município.

O Projeto, enfim, criou espaço para o encontro entre o Estado, na figura dos governantes do Município - Prefeita e Diretores - e interlocutores da sociedade civil, no presente caso, a Pastoral da Criança, mães e empresas locais.

Na verdade, o trabalho não acabou. Pelo contrário, está mais vivo do que antes, agora de forma mais consciente e na direção de um salto 
qualitativo, que pode vir a conduzir para o objetivo maior proposto, qual seja, de um Projeto, verdadeiramente de cunho sócio-político, tendo como cimento de sua construção, a participação cidadã da sociedade de Morungaba.

Neste sentido, os resultados, aqui apresentados, em forma de tese representam, tão somente, dados parciais de um processo em andamento, apresentando, até o momento, ganhos, conquistas importantes, mas para cujo desenvolvimento qualitativo, depende, ainda, de muito esforço de todos os envolvidos e por se envolverem.

Vale, neste momento, mesmo que de forma coloquial e sucinta, apresentar o significado atribuído pela pesquisadora ter participado/ estar participando do processo em desenvolvimento no Município de Morungaba.

Muitas vezes, há a lembrança do carinho e do respeito dos cidadãos de Morungaba para com o Projeto e com sua pessoa. Há a lembrança das crianças correndo, com os olhos brilhando de esperanças...

Todo esse movimento foi de intenso aprendizado, não apenas profissional mas, também de vida.

Sob a ótica profissional, a lição que ficou: não há necessidade de técnicas sofisticadas para mobilizar pessoas ou a si próprio, é preciso apenas exercitar a escuta $e$ o respeito.

...ao escutá-lo, aprendo a falar com ele.

Escutar é obviamente algo que vai além da possibilidade auditiva de cada um. Escutar ... significa a disponibilidade permanente por parte do sujeito que escuta para a abertura a fala do outro, ao gesto do outro... (FREIRE 1999, p. 135) 
Este aprendizado foi o mais importante, pois implicou reeducar os ouvidos e aprender a respeitar o ritmo dos participantes, para, coletivamente, conseguir construir algo de seu interesse.

Mais que um trabalho acadêmico, consistiu em um aprendizado e um exercício de vida... $O$ aprender/reaprender a ser humilde. Chegar a eles, com eles e junto deles...

"... humildade é um ato de força, de quem se priva de demonstrar sua superioridade, procurando valorizar o próximo..." (ALVES 2001, p. 63).

"A humildade exprime, ..., uma das raras certezas de que estou certo: a de que ninguém é superior a ninguém..."

"... Como posso respeitar a curiosidade do educando se, carente de humildade e da real compreensão do papel da ignorância na busca do saber temo revelar 0 meu desconhecimento?"(FREIRE 1999, p. 75)

Isto requer, do pesquisador, um despojamento nas atitudes, deixando de lado as facilidades e o conforto de trabalhar de forma centralizada $e$ ir ao encontro das pessoas, onde elas estão, com sua circunstância.

A emoção da pesquisadora é forte ao recordar-se dessas mulheres, professoras, coordenadoras, Diretora de Educação, agentes da Pastoral da Criança, auxiliares de enfermagem e mães... em sua maioria mulheres- zelando pela sua realidade e por seus espaços. Sim... foram elas que assumiram o leme e definiram a direção mais adequada, dando forma, movimento e sentido para o Projeto, com toda a sensibilidade $e$ carinho. 
O "empowerment" teve dupla mão: da pesquisadora para os atores sociais locais e destes para a pesquisadora, a partir de uma relação dialógica de construção permanente. 


\section{7 - REFERÊNCIAS}

Alvaro ME. Nossa experiência com o estabelecimento do treinamento ortóptico no Brasil. Rev Bras Oftalmol 1957; 16: 356.

Alves MR, Kara-José N. $O$ olho e a visão: o que fazer pela saúde ocular de nossas crianças. São Paulo: Ed. Vozes: 1996.

American Orthoptic Council About orthoptics [ on line ]. USA, 1999 Avaliable from: < URL: http://www.orthoptics.org [2000 20, Feb.]

Armond JE. Saúde ocular: conhecimentos, crenças e opiniōes de professores de primeira série do primeiro grau, do sistema público de ensino da região sul do município de São Paulo. São Paulo; 1998 .[ Dissertação de Mestrado - Faculdade de Saúde Pública da USP].

Arroyo HV, Cerqueira MT, editores. La promoción de la salud y la educación para la salud en América Latina: un análisis sectorial. San Juan, Puerto Rico: Ed. Univ. Puerto Rico/OPAS; 1997.

Barbieri Jean-Mari. Elaboração de projetos de ação e planificação. Porto: Porto Editora; 1993. 
Bordenave JD. $O$ que é participação. $8^{a}$. ed. São Paulo: Ed. Brasiliense: 1994 Coleção Primeiros Passos.

Brasil. Constituição da República do Brasil. Rio de Janeiro: Degrau Cultural; 1988. Art $^{\circ} 196$, Art $^{\circ} 30$ (al. VII).

Campos EC. Update on strabisms and amblyopia. Acta Ophthalmol Scand Suppl 1995; (214): 17-25; discussion 24-5.

Cerqueira MT. Promoción de la salud y educación para la salud: retos y perspectivas. In: Arroyo HV, Cerqueira MT, editores. La promoción de la salud y la educación para la salud en América Latina: un análisis sectorial. San Juan, Puerto Rico; Ed. Univ. de Puerto Rico/OPAS; 1997. p. 7-48.

Conselho Brasileiro de Oftalmologia. Manual de orientação - veja bem Brasil. São Paulo; Imprensa Oficial; 1998.

Costa MN, Kara-José N, Rueda G, Pereira VL, Favero M. Estudo da incidência de ambliopia, estrabismo e anisometropia em pré-escolares. Arq Bras Oftalmol 1979: (54): 249-53.

Crawford JS, Morin JD. The eye in childhood. Toronto, Dep. Ophthalmology: 1982. 
Cunha $A G$. Dicionário etimológico Nova Fronteira da língua portuguesa. $2^{a}$ ed. Rio de Janeiro: Ed. Nova Fronteira; 1997. p. 584

Czeresnia D. The concept of health and difference between prevention and promotion. Cad Saúde Pública 1999; 15: 701-9.

Dean AG, Dean JA, Coulombier D, Brendel KA, Smith DC, Burton AH et al. Epi Info, version 6: a world processing database, and statistics program for epidemiology on microcomputers. Centers for Disease Control and Prevention, Atlanta, Georgia, USA, 1994.

Demo P. Metodologia científica em ciências sociais. $4^{a}$ ed. São Paulo: Ed. Atlas; 1988.

Dias RB. "Eu? Eu estou aí, compondo o mundo." uma de controle de endemia, pesquisa e participação popular vivida em Cansanção, Minas Gerais, Brasil. Cad. Saúde Publica 1998, vol. 14 suppl. 2

Ferraz ST. Promoção da saúde: viagem entre dois paradigmas. Rev Adm Pública 1998: 32(2): 49-60.

Freire M, Davini J, Camargo F, Martins MC. Avaliação e planejamento: a prática educativa em questão. São Paulo: Espaço Pedagógico: 1997. (Instrumentos Metodológicos II) 
Freire P. Concientización. Buenos Aires: Ed. Busqueta; s/d. (Coleción "educación hoy")

Freire P. Pedagogia da autonomia: saberes necessários à prática educativa. $13^{a}$ ed. Rio de Janeiro: Paze Terra; 1999.

Fundação IBGE. Censo demográfico de 1991. [ on line ] Rio de Janeiro, 1991 Disponivel em URL: http://www.ibge.gov. [1999 10 Maio]

Fundação IBGE. Dados Preliminares do Censo de 2000. [ on line ] Rio de Janeiro, 2000 Disponivel em URL: http://www.ibge.gov. [2001 8 Fev.]

Gil AC. Métodos e técnicas de pesquisa social. $5^{a}$ ed. São Paulo: Atlas; 1999.

Gillies P. Effectiveness of alliances and partnerships for health promotion. Health Promot Int 13 (2): 99-120; 1998.

Green LW, Kreuter MW. Health promotion planning: an education and environmental approach. $2^{\text {nd }}$ ed. Toronto: Mayfield Publications: 1991. 
Harris JS. The health benefits of health promotion. In: O Donnell MP, Harris JC. Health promotion in the workplace. $2^{\text {nd }}$ ed. Washigton, DC: Delmar Publishers; 1992. p 3-6

Izeckson L. Triagem visual em pré-escolares e escolares. São Paulo; 1972. [Dissertação de Mestrado - Faculdade de Saúde Pública da USP].

Kara-José N, Carvalho KMM, Caldato R, Perreira VL, Oliveira MD, Neto JCF. Atendimento de amblíopes e prevalência na população pré-escolar, Campinas, SP, Brasil. Bol Ofic Sanit Panam 1984a; 96: 31-7.

Kara-José N, Holzchuh N, Temporini ER. Vícios de refração em escolares da cidade de São Paulo - Brasil. Bol Ofic Sanit Panam 1984b; 96: 32631.

Kara-José N, Almeida GV, Arieta CE, Araújo JS, Bechara SJ, Oliveira PR. Causas de deficiência visual em crianças. Bol Ofic Sanit Panam 1984c: 97: 405-13.

Kara-José N, Oliveira RC. Mitos e verdades: olhos. São Paulo: Contexto; 1997.

Kickbusch I. New health promotion iniciatives. Geneva, 1997 (Press release $\mathrm{WHO} / 63$ ) 
Kinker RBF. A atuação do ortoptista na área da saúde. Bol Bras Ortópt 1983/1984; (11): 37-46.

Labonte R. Health promotion and empowerment: reflections or professional pratice. Health Educ Q 1994; 21: 253-68.

Labonte R. Health promotion and the common good: towards a politic of pratice. Crit Public Health 1998a: 8:107-29.

Lalonde M. El concepto de "campo de la salud": una perspectiva Canadense. In: Organización Panamericana de la Salud. Promoción de la salud: una antología. Washington DC: 1994. (OPAS Publicación Científica $\left.n^{\circ} 557\right)$.

Laurell AC. A saúde-doença como processo social. In: Nunes, ED, organizador. Medicina Social: aspectos históricos e teóricos. São Paulo: Global: 1983. p. 133. (Textos 3)

Lauretti $A$, Romão E. Estudo da acuidade visual e dos vícios de refração em crianças com baixo rendimento escolar. Rev Bras Oftalmol 1982; 41(5): 31-6.

Leavell HR, Clark EG. Preventive medicine for the doctor in his community: an epidemiological approach. $3^{\text {rd }}$ ed. New York: MacGrawHill; 1965. 
Lima VLP. Campos NR. Educación en salud: sinopsis histórica y algunas tendencias. In: Arroyo HV, Cerqueira MT, editores. La promotion de la salud y La education para la salud en América Latina: un análisis sectorial. San Juan, Puerto Rico: Univ. Puerto Rico/OPAS; 1997. p. $32-$ 68.

Lin-Fun JS. Vision screening of children. US Department of Health, Maternal and Child Health Service, 1971. p. 12-13

Machado JN. Educação: projetos e valores. São Paulo: Escritura Editora: 2000 (Coleção Transversais).

Mendes EV. A organização da saúde no nível local. São Paulo: Hucitec; 1998.

Ministério da Saúde. $8^{a}$ Conferência Nacional de Saúde. Brasília: Ministério da Saúde: 1986.

Ministério da Saúde. Secretaria Nacional de Programas Especiais de Saúde. Divisão Nacional de Doenças Crônico-Degenerativas. Programa Nacional de Saúde Ocular e Prevenção da Cegueira. Brasília, DF: 1988. 
Ministério da Saúde. Promoção da Saúde: Carta de Ottawa, Declaração de Adelaide, Sundsvall e Santa Fé de Bogota. Brasília, DF; 1996.

Ministério da Saúde. A declaração de Jacarta sobre a promoção da saúde no século XXI. Brasilia, DF; 1997 (Setor de Informação, Educação e Comunicação)

Ministério da Saúde Programas e Projetos. Saúde Ocular. [on line].

Brasília, 1997. Avaliable from: <

http://www.saúde.gov.br/Programas/ocular/ [2001 15 Jan.]

Naidoo J, Wills J. Health promotion: foundations for practice. $3^{\text {nd }} \mathrm{ed}$. London: Baillière Tindall; 1996.

Nutbeam D, Harris $E$. Theory in a Nutshell: a practtioner's guide to commonly used theories and models in health promotion. Sydney: Departament of Public health and Community Medicine-University of Sydney; 1998.

Nutbeam D. Health promotion glossary. Health Promot Int 1999; 4: 349-64. 
O'Donnell MP, Harris JS. Health promotion in the workplace. $2^{\text {nd }}$ ed. Washigton, DC: Delmar Publishers; 1992.

Organização Mundial de Saúde. Declaração de Alma Ata: a estratégia de atenção primária em saúde. UNICEF, Genebra: 1978.

Organización Mundial de la Salud. Atención primaria de salud: informe de la Conferencia Internacional sobre Atención Primaria de Salud, Alma Ata, no 1, 6-13. Ginebra; 1978.

Organización Mundial de la Salud. Estratégias para la ceguera en programa nacional. Ginebra; 1984.

Organización Panamericana de la Salud. Desarollo y fortalecimiento de los sistemas locales de salud - la participación social. Washington DC: 1990 (HSD/SILOS- 3).

Organización Panamericana de la Salud. Promoción de la salud: una antología. Washington DC; 1994. (OPAS Publicación Cientifica 557).

Organización Panamericana de la Salud. Desarollo y fortalecimiento de los sistemas locales de salud - la administracion estrategica. Washington DC; 1995; (HSD/SILOS -2). 
Organización Panamericana de la Salud. Desarrollo y fortalecimiento de los sistemas locales de salud - la participación social en el desarrollo de la salud: experiencias latinoamericanas. Washington DC; 1997 (HSD/SILOS - 35).

Panamerican Health Organization. Primary eye care manual. Washington, DC: $1985 ;$ p. 1-42.

Prefeitura Municipal de Morungaba. Compêndio histórico de Morungaba. Biblioteca Municipal de Morungaba, 1993.

Rizzini I, Castro MR, Sartor CD. Pesquisando... guia de metodologias de pesquisa para programas sociais. Rio de Janeiro: EDUSU; 1999. (Série Banco de Dados, 6).

Robirosa M, Cardarelli G, Lapalma AI, Caleti S. Turbulencia Y planificacion social: lineamientos metodológicos de gestión de proyectos sociales desde el Estado. Buenos Aires: Siglo Veintuno de España Editores SA; 1990.

Rouquayrol, MZ, Epidemiologia \& Saúde. $4^{a}$ ed. Rio de Janeiro: MEDSI; 1993.

Santos LL. Textos de serviço social. $5^{\circ}$. ed. São Paulo: Cortez; 1993. 
Santos L. Saúde integral do adolescente: a concepção de participação e o seu lugar no discurso oficial da saúde pública. São Paulo, 1998 (relatório apresentado ao CNPq - Projeto PIBIC).

São Paulo. Secretaria de Estado de Saúde. Instituto de Saúde. Serviços de Oftalmologia Sanitária. Plano de oftalmologia sanitária escolar. São Paulo; 1973.

São Paulo. Secretaria de Estado de Saúde. Coordenação de Saúde da Comunidade. Norma técnica especial: instilação obrigatória da solução de Nitrato de Prata $1 \%$ nos olhos dos recém-nascidos. São Paulo; 1977. (Decreto $n^{\circ}$ 9713)

São Paulo. Secretaria de Estado de Saúde. Instituto de Saúde. Serviços de Oftalmologia Sanitária. Plano Nacional de Saúde Ocular. São Paulo; 1984.

Scarpi MJ, Kara-José N, Taiar A. Incidência de ambliopia em 1400 escolares da cidade de São Paulo em 1975. Arq Bras Oftalmol 1977: (40): $16-23$.

Souza GC. Educação em saúde nas escolas. Anais Nestlé 1977; (100): 7181. 
Sperandio AMG. Assistência à saúde ocular de crianças nos serviços de saúde pública do Município de Campinas, 1993-1994. São Paulo; 1994. [Dissertação de Mestrado - Faculdade de Saúde Pública da USP]

Sperandio AMG. Capacitação de professores e pajens para detecção precoce de problemas visuais: relato de uma experiência. Rev Bras Saúde Esc 1990; 1: 22-5.

Sperandio AMG. A promoção da saúde ocular e a prevenção precoce de problemas visuais nos serviços de saúde pública de Campinas. Rev Saúde Pública 1999a; 33:513-520.

Sperandio AMG. Cartilha do programa saúde do escolar para o Município de Campinas, seção: Saúde Ocular. Campinas, Secretaria Municipal Educação: 1999b. p. 11-12.

Temporini ER, Kara-José N, Rigolizzo HB. Envolvimento do pessoal da comunidade em projeto de detecção de ambliopia em pré-escolares. Arq Bras Oftalmol 1983: 46: 85-9.

Temporini ER, Kara-José N. Níveis de prevenção de problemas oftalmológicos: proposta de investigação. Arq Bras Oftalmol 1995; 58:189-94. 
Temporini ER. Promoção da saúde ocular. Arq Bras Oftalmol [periódico on line] 1998; 62 (1). Disponivel em <URL: http://www.cbo.com.br [1999 5 Novembro].

Thylefors B. A simplified methodology for the assessment of blindness and its main causes. World Health Stat Q 1987: 40: 129-41.

Thylefors B, Négrel AD, Pararajasegaram R, Dadzie KY. Global data on blindeness. Bull. WHO 1995; 73:115-121. [Document on line] Avaliable at: URL $h t t p: / / w w w . w h o . i n t / p b d / d a t a . h t m \# p u b l i c a t i o n s]\left[\begin{array}{ll}1999 & 5\end{array}\right.$ Novembro].

Vasconcelos EM. A proposta de "empowerment" e a sua complexidade: uma revisão histórica na perspectiva do Serviço Social e da Saúde Mental. Serv. Social 2001: 65: 5-53.

Westphal MF, Ziglio E. Políticas públicas $e$ investimentos: a intersetorialidade. In: Fundação Prefeito Faria Lima. O município no século XXI: cenário e perspectivas. São Paulo; 1999. p. 111-121. (Recursos educativos e métodos de avaliação em promoção da saúde).

[WHO] World Health Organization. Health promotion: a discussion document on the concept and principles. Copenhagen; 1984. 
[WHO] World Health Organization. Ottawa charter for health promotion. Geneva Health and Welfare Canada, Canada Public Health Association/WHO; 1986.

[WHO] World Health Organization. Health promotion and a new public health. Geneva: 1997. Discussion notes 2. [Document on line] Avaliable at: URL: http://www.who.org. [2000 20 Maio]

[WHO] World Health Organization. Fifth Global Conference for Health Promotion - Health Promotion: bridging the equity gap: Conference Report. Geneva; 2000. [Document on line] Avaliable at: URL: http://www.who.int/hpr/conference/proceeding. [2001 5 Feb.] 